\title{
ABORDAGENS DA \\ ENGENHARIA CIVIL NO ESPAÇO SERGIPANO
}

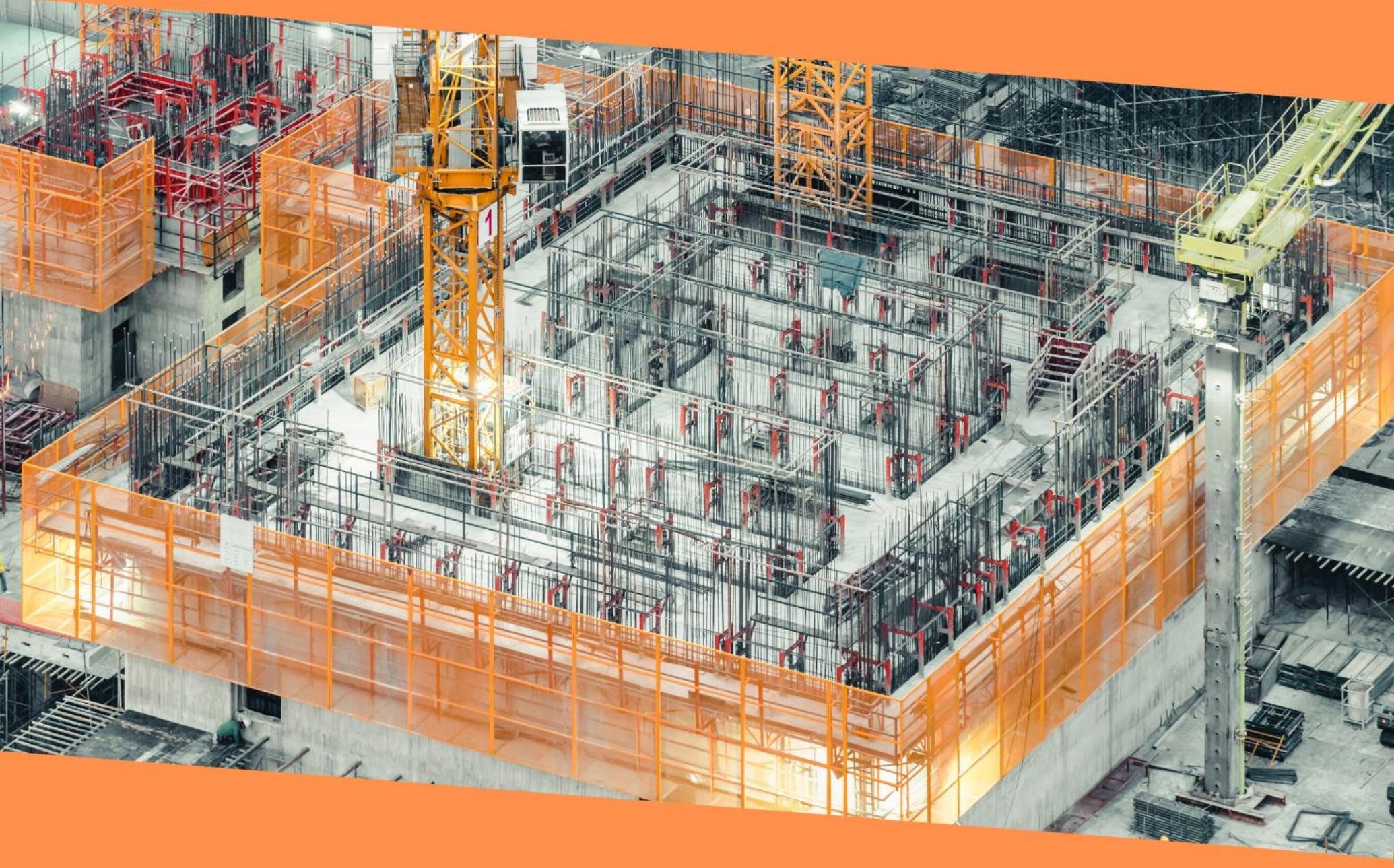

ORGANIZADORES

IRIS STERFANIE SANTOS

NEUMA RÚBIA FIGUEIREDO SANTANA

Fditora Poisson SANDRO IURY VALVERDE LIMA DA CRUZ 


\section{Organizadores}

Iris Sterfanie Santos

Neuma Rúbia Figueiredo Santana

Sandro Iury Valverde Lima da Cruz

\section{Abordagens da engenharia civil no espaço sergipano}

1a Edição

Belo Horizonte

Poisson

2019 
Editor Chefe: Dr. Darly Fernando Andrade

\section{Conselho Editorial}

Dr. Antônio Artur de Souza - Universidade Federal de Minas Gerais

Msc. Davilson Eduardo Andrade

Dra. Elizângela de Jesus Oliveira - Universidade Federal do Amazonas

Msc. Fabiane dos Santos

Dr. José Eduardo Ferreira Lopes - Universidade Federal de Uberlândia

Dr. Otaviano Francisco Neves - Pontifícia Universidade Católica de Minas Gerais

Dr. Luiz Cláudio de Lima - Universidade FUMEC

Dr. Nelson Ferreira Filho - Faculdades Kennedy

Msc. Valdiney Alves de Oliveira - Universidade Federal de Uberlândia

Dados Internacionais de Catalogação na Publicação (CIP)

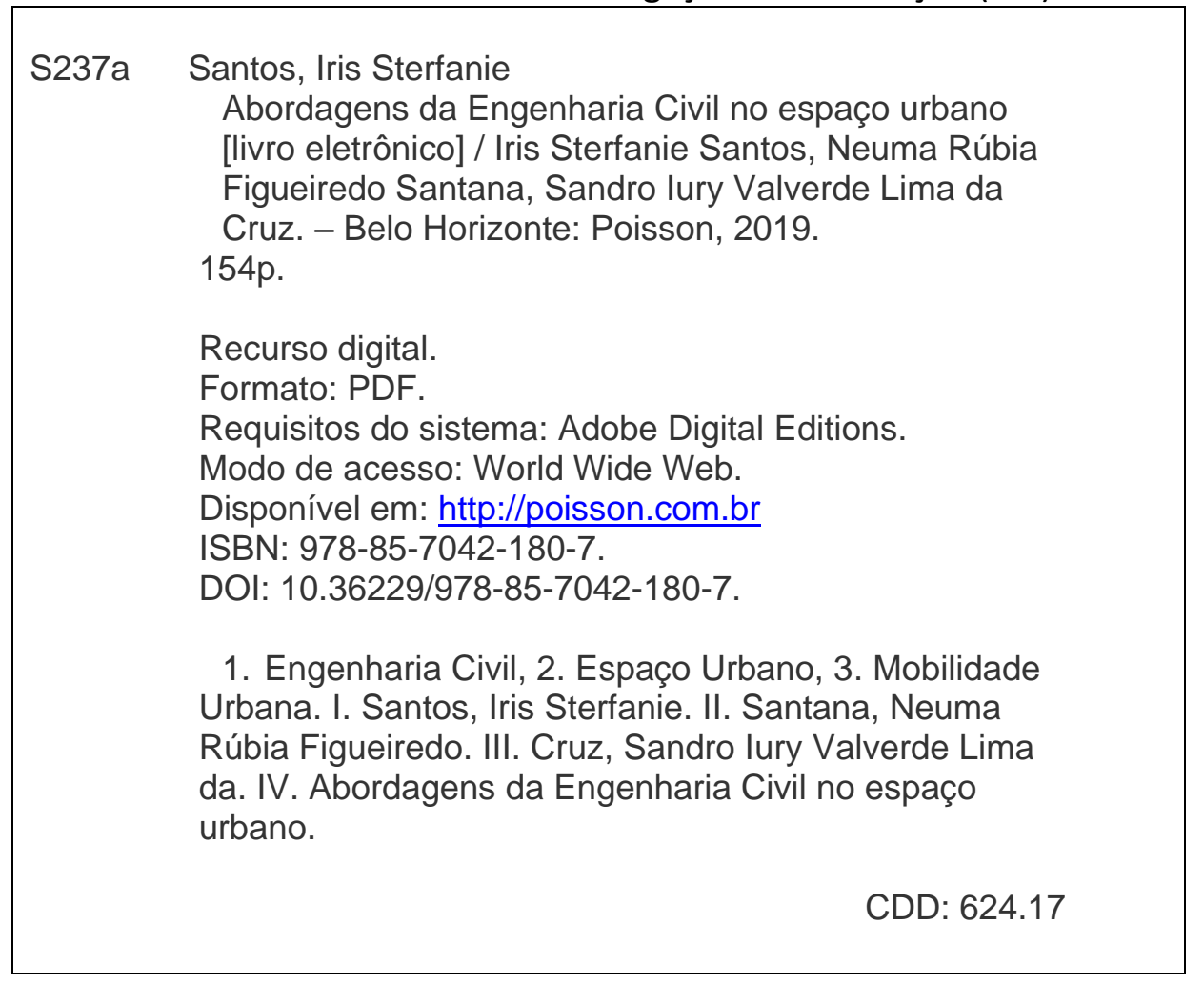

O conteúdo dos artigos e seus dados em sua forma correção e confiabilidade são de responsabilidade exclusiva dos seus respectivos autores.

www.poisson.com.br

contato@poisson.com.br 


\section{PREFÁCIO}

Diante da nova realidade que perpassa o cenário da Construção Civil no Brasil, e das perspectivas para o novo mercado de trabalho, faz-se necessário que os novos profissionais possuam uma visão crítica, desenvolvendo uma visão que leve em consideração, não apenas as questões técnicas de engenharia, mas também os problemas sociais e ambientais que estão inter-relacionados. O Trabalho de Conclusão de Curso (TCC) tem como função estimular o graduando de engenharia civil a exercitar o seu espírito questionador, buscando soluções inovadoras para solução de problemas, buscando atender as necessidades da sociedade, com o menor custo e preservando o meio ambiente. Os trabalhos apresentados neste E-Book foram decorrentes desta busca de conhecimento técnico cientifico envolvendo professores e alunos no último semestre do curso. Isto por que entendemos que o engenheiro Civil atua na supervisão, coordenação técnica, elaboração de projetos e execução, manutenção, recuperação de obras de construção civil e pesquisa.

Sandro lury Valverde Lima da Cruz

(Coordenador do curso)

Neuma Rúbia Figueiredo Santana

(Presidente do NDE) 


\section{Autores}

\begin{tabular}{|c|c|}
\hline Autor & Qualificação \\
\hline Almir Querino de Melo & $\begin{array}{l}\text { Engenheiro Eletricista, Professor e Mestre em Desenvolvimento e Meio } \\
\text { Ambiente, Faculdade Pio Décimo. }\end{array}$ \\
\hline Bárbara Maria Gomes Santana & Engenheira Civil, Faculdade Pio Décimo. \\
\hline Carlos Alfonso Alva Alvarado & $\begin{array}{l}\text { Engenheiro Agrícola, Professor e Mestre em Irrigação e Drenagem, } \\
\text { Faculdade Pio Décimo. }\end{array}$ \\
\hline Caynara Santos Costa & Engenheira Civil, Faculdade Pio Décimo. \\
\hline Danilo Leite Almeida de Sá & Engenheiro Civil, Faculdade Pio Décimo. \\
\hline Dayane Santana Santos & Engenheira Civil, Faculdade Pio Décimo. \\
\hline Edineide Correia Fraga & Engenheira Civil, Faculdade Pio Décimo. \\
\hline Giseli Barbosa de Lima & $\begin{array}{l}\text { Engenheira Civil, Professora e Mestra em Engenharia Civil, Faculdade } \\
\text { Pio Décimo. }\end{array}$ \\
\hline Gladston Nogueira Matos & Engenheiro Civil, Faculdade Pio Décimo. \\
\hline Hilderardi Mendonça de Melo & $\begin{array}{l}\text { Engenheiro Civil, Professor e Mestre em Engenharia Estrutural, } \\
\text { Faculdade Pio Décimo. }\end{array}$ \\
\hline Ihana Gabriela Conceição de Jesus & $\begin{array}{l}\text { Graduanda em Ciência e Engenharia de Materiais, Universidade } \\
\text { Federal de Sergipe. }\end{array}$ \\
\hline Iris Sterfanie Santos & $\begin{array}{l}\text { Engenheira Civil, mestranda em Ciência e Engenharia de Materiais, } \\
\text { Universidade Federal de Sergipe. }\end{array}$ \\
\hline Jislaine dos Santos Carvalho & Engenheira Civil, Faculdade Pio Décimo. \\
\hline Jorge Eduardo Fontes Leite & $\begin{array}{l}\text { Administrador, Professor e Especialista em Gestão Acadêmica e } \\
\text { Formação Docente, Faculdade Pio Décimo. }\end{array}$ \\
\hline Leonardo Medina Rosário & $\begin{array}{l}\text { Engenheiro Civil, Professor e Especialista em gerenciamento de } \\
\text { projetos, Faculdade Pio Décimo. }\end{array}$ \\
\hline Luciana Silva Melo Da Cruz & Engenheira Civil, Professora, Faculdade Pio Décimo. \\
\hline Maria Andreza Santana Almeida & Engenheira Civil, Faculdade Pio Décimo. \\
\hline Maria Daylanne Oliveira Santos & Engenheira Civil, Faculdade Pio Décimo. \\
\hline Mayara Sales Sobral Freitas & Engenheira Civil, Faculdade Pio Décimo. \\
\hline Neuma Rúbia Figueiredo Santana & $\begin{array}{l}\text { Bióloga, Professora e Doutora em Desenvolvimento e Meio Ambiente, } \\
\text { Faculdade Pio Décimo. }\end{array}$ \\
\hline Romário de Jesus Santo & $\begin{array}{l}\text { Engenheiro Civil e Professor, Mestre em Engenharia Estrutural, } \\
\text { Faculdade Pio Décimo. }\end{array}$ \\
\hline Sandro Iury Valverde Lima da Cruz & $\begin{array}{l}\text { Engenheiro Civil, Professor e Mestre em Desenvolvimento e Meio } \\
\text { Ambiente, Faculdade Pio Décimo }\end{array}$ \\
\hline Victor Manuel de Queiroz Lourenço & $\begin{array}{l}\text { Engenheiro Civil, Professor e Mestre em Geotecnia, Faculdade Pio } \\
\text { Décimo. }\end{array}$ \\
\hline Vinícius Sousa dos Santos & Engenheiro Civil, Faculdade Pio Décimo. \\
\hline
\end{tabular}




\section{SUMÁRIO}

Capítulo 1: Mobilidade urbana sustentável na região metropolitana de Aracaju/SE 08

Edineide Correia Fraga, Luciana Silva Melo da Cruz

DOI: 10.36229/978-85-7042-180-7.CAP.01

Capítulo 2: Análise comparativa entre concreto armado convencional e concreto protendido na execução de edifício vertical residencial no município de Aracaju ........23

Maria Andreza Santana Almeida, Hilderardi Mendonça de Melo, Iris Sterfanie Santos

DOI: $10.36229 / 978-85-7042-180-7 . C A P .02$

Capítulo 3: Avaliação dos aspectos e impactos socioambientais no complexo termoelétrico porto de Sergipe no município de Barra dos Coqueiros/SE

Dayane Santana Santos, Neuma Rúbia Figueiredo Santana, Iris Sterfanie Santos

DOI: $10.36229 / 978-85-7042-180-7 . C A P .03$

Capítulo 4: Compatibilização de projetos empregando modelos parametrizados Concepções da modelagem BIM

Danilo Leite Almeida de Sá, Jorge Eduardo Fontes Leite

DOI: 10.36229/978-85-7042-180-7.CAP.04

Capítulo 5: Caracterização geotécnica de solo com vistas à aplicação em camada de base de pavimentos da cidade de Aracaju/SE 62

Mayara Sales Sobral Freitas, Victor Manuel de Queiroz Lourenço

DOI: 10.36229/978-85-7042-180-7.CAP.05

Capítulo 6: Inspeção e catalogação de manifestações patológicas em estrutura metálica de terminal de integração

Iris Sterfanie Santos, Leonardo Medina Rosário, Ihana Gabriela Conceição de Jesus

DOI: 10.36229/978-85-7042-180-7.CAP.06

Capítulo 7: A degradação da nascente do Riacho do Xoxota no município de São Cristóvão por despejo de efluentes domésticos.

Caynara Santos Costa, Almir Querino de Melo

DOI: 10.36229/978-85-7042-180-7.CAP.07

Capítulo 8: Patologia em revestimento de argamassa em residências unifamiliar provenientes dos efeitos da umidade 102

Gladston Nogueira Matos, Giseli Barbosa de Lima

DOI: 10.36229/978-85-7042-180-7.CAP.08 


\section{SUMÁRIO}

Capítulo 9: Embargo e interdição na indústria da construção civil em Aracaju/SE:

Análise da percepção de alunos e profissionais da área.

Maria Daylanne Oliveira Santos, Sandro Iury Valverde Lima da Cruz

DOI: $10.36229 / 978-85-7042-180-7 . C A P .09$

Capítulo 10: Estudo das propriedades do concreto utilizando como parte do cimento a cinza de casca de arroz.

Vinícius Sousa dos Santos, Romário de Jesus Santo, Bárbara Maria Gomes Santana

DOI: $10.36229 / 978-85-7042-180-7 . C A P .10$

Capítulo 11: Diagnóstico do abastecimento de água, coleta e tratamento do esgoto sanitário da cidade de Lagarto/SE

Jislaine dos Santos Carvalho, Carlos Alfonso Alva Alvarado DOI: 10.36229/978-85-7042-180-7.CAP.11 


\section{Capítulo 1}

\section{Mobilidade urbana sustentável na região metropolitana de Aracaju/SE}

\section{Edineide Correia Fraga \\ Luciana Silva Melo da Cruz}

Resumo: A progressiva utilização dos veículos individuais, seja pela forte valorização social, seja pela sua comodidade, tem contribuído para elevação dos níveis de saturação de trânsito, o que repercute cada vez mais no funcionamento das cidades, reduzindo a mobilidade de uma forma global, deteriorando o ambiente e diminuindo a qualidade de vida. Essa pesquisa visa apresentar uma análise do transporte urbano em vários modos com o propósito de proporcionar a compreensão dos aspectos que envolvem a mobilidade urbana do ponto de vista do usuário qualificando os elementos envolvidos neste processo e compará-los aos projetos tidos como sustentáveis para a região metropolitana de Aracaju. Nesse contexto, foi realizada uma pesquisa de multicritério, e para coleta de dados foi levado em conta à área metropolitana de Aracaju. Os principais resultados evidenciam que a falta de planejamento e investimentos dos setores competentes tem trazido grandes prejuízos à população, mostrando dificuldades nos deslocamentos para as atividades principais. Para que a sustentabilidade realmente aconteça é necessário priorizar e incentivar o uso do transporte coletivo e uso da bicicleta, com o intuito de reduzir os efeitos negativos provocados pelo uso predominante do automóvel.

Palavras-chave: Mobilidade urbana, mobilidade urbana sustentável, transporte. 


\section{INTRODUÇÃO}

A mobilidade urbana estabelece um fator crucial no desenvolvimento sustentável das cidades. No entanto, a progressiva utilização dos veículos individuais, seja pela forte valorização social, seja pela sua comodidade, tem contribuído para elevação dos níveis de saturação de trânsito, o que repercute cada vez mais no funcionamento das cidades, reduzindo a mobilidade de uma forma global, deteriorando o ambiente e diminuindo a qualidade de vida.

Nos últimos tempos o tráfego nos grandes centros urbanos tem sido agravado significativamente por congestionamentos cada vez intensos, resultando no acréscimo dos tempos de deslocamentos tanto no transporte individual quanto no coletivo, além de causar menor qualidade de vida das pessoas (MENDES JUNIOR, DR.; FUSCO, 2013).

Verifica-se uma redução gradativa da acessibilidade causada pela falta de um planejamento urbano aliado ao crescimento populacional desordenado e principalmente, pelo aumento de veículos em circulação. Em contrapartida, ao mesmo tempo em que se aumenta a taxa de motorização por transporte privado, o uso do transporte coletivo vem decaindo. Tal redução tem como resultado a degradação e encarecimento desses serviços, o que os torna menos atrativos, instigando o uso de automóveis como meio de transporte.

A qualidade de vida para as cidades brasileiras implica na adoção de medidas destinadas a garantir uma mobilidade urbana que vise à acessibilidade de todos aos serviços, bens e oportunidades existentes. Além de assegurar a segurança e combate eficaz ao genocídio no trânsito; que atue com efetividade na melhoria das condições ambientais, reduzindo a poluição, qualificando os espaços públicos, que potencialize o desenvolvimento econômico, amplie a solidariedade social, que promova a coesão geográfica; e que priorize a acessibilidade e a mobilidade as pessoas e não aos veículos (AFFONSO et al., 2018).

0 objetivo desta pesquisa visa apresentar uma análise do transporte urbano em vários modos, com o propósito de proporcionar a compreensão dos aspectos que envolvem a mobilidade urbana do ponto de vista do usuário qualificando os elementos envolvidos neste processo e compará-los aos projetos tidos como sustentáveis para a região metropolitana de Aracaju.

\section{METODOLOGIA}

Nesta fase, apresentam-se os procedimentos metodológicos através de pesquisa de multicritério. Costa (2008) sugere que a metodologia do multicritério permite a integração entre os fatores qualitativos e quantitativos, bem como o correto tratamento da subjetividade presente no processo de decisão.

Desse modo, a pesquisa foi utilizada para análise do transporte urbano em vários modos, com o propósito de proporcionar a compreensão dos aspectos que envolvem a mobilidade urbana do ponto de vista do usuário, qualificando os elementos envolvidos neste processo e comparando-os aos projetos tidos como sustentáveis para a região metropolitana de Aracaju.

O município de Aracaju perfaz uma área de $181,857 \mathrm{~km}^{2}$, situado no estado de Sergipe, compreendido entre as coordenadas geográficas $10^{\circ} 55^{\prime} 56^{\prime \prime}$ de latitude Sul e $37^{\circ} 04^{\prime} 23^{\prime \prime}$ longitude oeste. De acordo com o Censo de 2010, a cidade consta com 570.937 habitantes e com estimativa para 2017 de 650.106 habitantes. Vale ressaltar que a região metropolitana é formada pelos municípios que formam a Grande Aracaju: Nossa Senhora do Socorro, Barra dos Coqueiros e São Cristóvão, onde o número passa para 835.564 habitantes (Figura 1). 
Figura 1: Localização geográfica de Aracaju

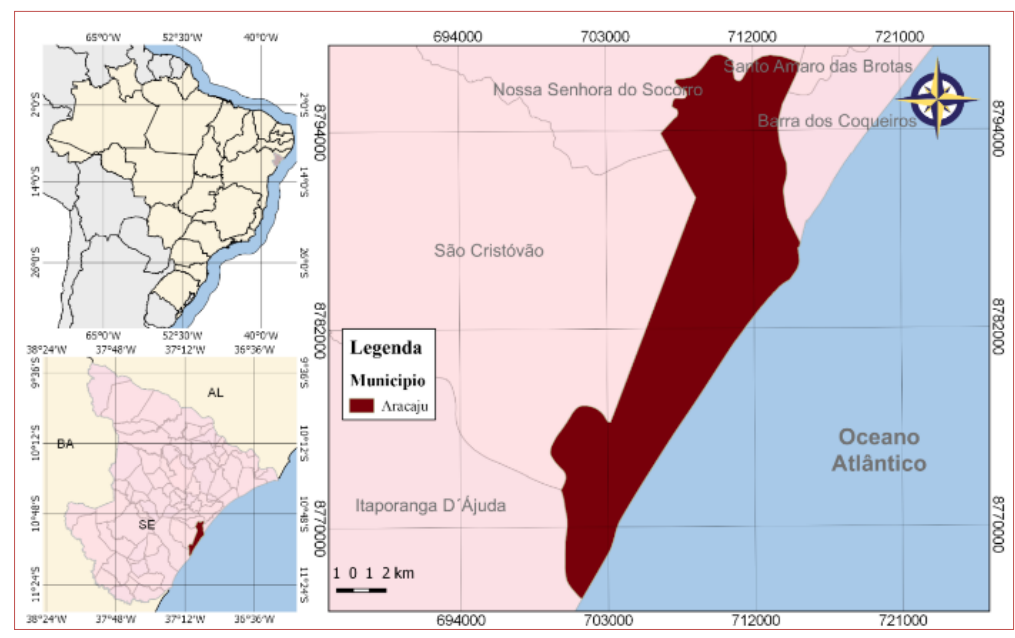

Fonte: SEMARH, 2016.

A obtenção dos dados teve seu início por meio de revisão bibliográfica em livros, legislações vigentes, teses, artigos, monografias, portais na internet, como o Google acadêmico, Biblioteca Digital Brasileira de Teses e Dissertações - BDTD, referente ao tema escolhido. Além disso, foram usados arquivos da prefeitura municipal de Aracaju, como o Plano Diretor de Desenvolvimento Urbano (PDDU) e o Plano de Mobilidade Urbana.

A presente pesquisa está dividida em três partes: a primeira parte traz o referencial teórico através da concepção da Mobilidade e a Infraestrutura Urbana, planejamento urbano da cidade através do plano diretor, Indústria automobilística no Brasil, o desenvolvimento econômico e o alto índice de motorização, os impactos ao meio ambiente, modos de transportes urbanos, mobilidade urbana sustentável, distribuição modal balanceada, transporte motorizado, transporte não motorizado e alternativa de transporte sustentável.

A segunda é composta pelos processos metodológicos para o levantamento da pesquisa como a área de estudos, coleta de dados e a análise dos dados. Na terceira é proposta uma análise crítica dos resultados, a consolidação dos dados e por fim as considerações finais onde se busca mostrar a mobilidade urbana nos dias atuais na cidade de Aracaju, ressaltando as dificuldades que os cidadãos têm diariamente para seu deslocamento.

Para enfim verificar a mobilidade urbana sustentável em Aracaju, os dados coletados em campo foram analisados através de gráficos e planilhas eletrônicas para uma melhor compreensão da pesquisa aplicada. Desta forma, a pesquisa, visa a análise de dados comparativos entre os modos de transportes mais utilizados na região metropolitana de Aracaju. Assim como, na opinião dos usuários de vários modos de transporte coletada através de questionário.

\section{RESULTADO E DISCUSSÃO}

Faz parte da região metropolitana de Aracaju o município de São Cristóvão, 4 a cidade mais antiga do Brasil com uma população estimada em 89.232 habitantes segundo censo do IBGE (2017). O conjunto habitacional Eduardo Gomes, fica localizado a $10 \mathrm{~km}$ do centro da Capital e a aproximadamente $15 \mathrm{Km}$ para o Centro de São Cristóvão. A proximidade da capital tornou-se um grande atrativo aos habitantes do município de São Cristóvão, seja pela oportunidade empregos, estudos, lazer entre outras.

Em contrapartida a cidade de São Cristóvão conta com o campus da Universidade Federal de Sergipe, instalado no Bairro Rosa Elze, onde atrai profissionais e estudantes do estado e estados vizinhos, tornando os arredores da universidade um grande centro habitacional, fazendo aumentar a população e com isso, a necessidade de descolamento para a capital.

Para atingir o objetivo proposto, foram realizadas pesquisas de campo, onde foi realizado um percurso utilizando os meios de transporte privado individual (carro, bicicleta) e transporte público (ônibus). Além 
da realização de entrevistas, onde utilizou-se uma amostragem de 166 entrevistados de várias regiões da grande Aracaju, através de questionário, buscando uma visão dos usuários dos modos de transporte.

\subsection{PERCURSO REALIZADO COM TRANSPORTE PRIVADO (CARRO)}

Em Aracaju ocorre o contrário do estabelecido no Plano Nacional de Mobilidade Urbana. A população é conduzida a adquirir um veículo particular e fazer uso dele como meio principal de deslocamento, em detrimento ao uso transporte público. Em janeiro de 2018, segundo estatística do Departamento Estadual De Trânsito De Sergipe - DETRAN a cidade possuía aproximadamente 284.828 veículos automotores onde 166.319 são carros. O crescente número de veículos impacta na sustentabilidade com aumento de emissão de poluentes, comprometendo a qualidade de vida dos aracajuanos, além de contribuir para o aquecimento global com o chamado "efeito estufa".

O levantamento de dados com o uso do veículo privado (carro) foi realizado em 17 de abril de 2018, o qual teve início na Rua José Almicar Azevedo, Conjunto Eduardo Gomes, Bairro Rosa Elze, na cidade de São Cristóvão, com extensão de 10,3 Km até o Terminal do Distrito Industrial - DIA, situado na Av. Pref. Heráclito G. Rollemberg, Inácio Barbosa, na cidade de Aracaju (Figura 2).

Figura 2: Percurso realizado com modo de transporte individual (carro)

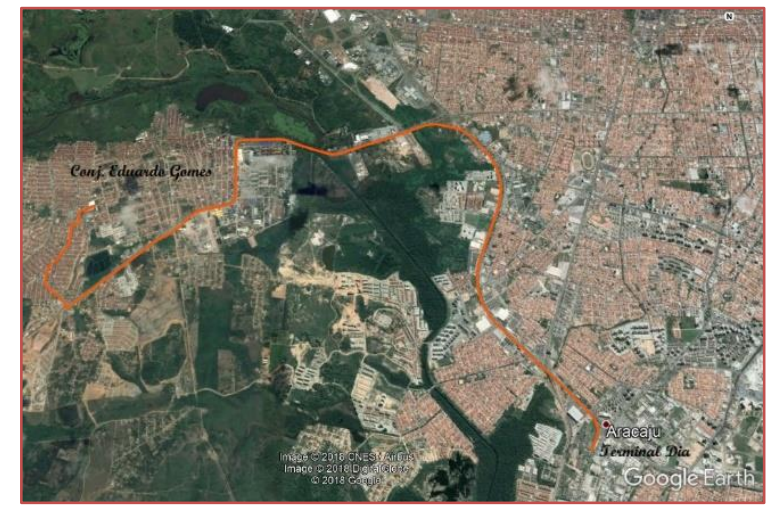

Fonte: Google Earth, 2018.

A primeira viagem teve início as $7 \mathrm{~h} 30 \mathrm{~min}$, horário com grande intensidade de tráfego. As vias do percurso escolhido não tem boa trafegabilidade, apresentando buracos, recapeamento asfáltico mal executado, com desníveis. 0 trânsito flui tranquilo nas emidiações do Bairro Rosa Elze, o congestionamento de veículos inicia a partir da Avenida Presidente Tancredo Neves, onde há grande quantidade de veículos que em conjunto com as paradas nos semáforos, sendo 05 (cinco) nesse trajeto faz com que o tráfego apresente vários pontos de congestionamentos deixando dessa forma o fluxo mais lento.

Embora possua faixa de preferência para o transporte público em boa parte do percurso, é importante salientar que muitos motoristas de transporte privado não respeitam a faixa exclusiva, prejudicando a livre circulação do transporte público. A viagem alcançou seu destino final às $7 \mathrm{~h} 45 \mathrm{~min} 29 \mathrm{seg}$, com duração de 15min29seg.

A segunda viagem foi realizada no mesmo dia iniciando as $18 \mathrm{~h}$ sendo utilizado o mesmo percurso, alcançando seu destino final as $18 \mathrm{~h} 20 \mathrm{~min} 43 \mathrm{seg}$, com duração de $20 \mathrm{~min} 43 \mathrm{seg}$. A viagem à noite teve as mesmas características da manhã, onde mais uma vez, na Avenida Presidente Tancredo Neves, o trânsito mais lento, com congestionamentos, tornando a viagem alguns minutos mais lenta.

0 deslocamento realizado com transporte privado torna-se uma viagem cômoda, segura. A duração da viagem também deve ser levada em conta, pois comparado com o transporte público e com a biclicleta teve seu menor tempo de deslocamento. Observou-se que nesse trajeto há uma boa sinalização de trânsito com placa de advertências, semáforos e faixas de pedestres, deixando a desejar a infraestrutura das vias.

Segundo o planejamento estratégico da gestão municipal de Aracaju um dos focos é implantar o sistema de Mobilidade Urbana inteligente para os cidadãos, com ações educativas para o trânsito com estimativa de prazo de projeto até Julho de 2018 e ampliar a acessibilidade na cidade melhorando a infraestrutura e acessibilidade dos bairros da cidade com estimativa de prazo de projeto para depois de Julho de 2018 (ARACAJU, 2018). 


\subsection{PERCURSO REALIZADO COM TRANSPORTE NÃO MOTORIZADO (BICICLETA)}

As pessoas que utilizam a bicicleta como meio de transporte em Aracaju estão expostas ao tráfego e carecem de maior atenção quanto ao planejamento do sistema cicloviário. Muitos desistem de utilizar esse modo pela insegurança, pelo risco oferecido e pela falta de ciclovias.

O levantamento de dados com o uso do veículo não motorizado (bicicleta) foi realizado em 18 de abril de 2018, o qual teve início na Rua José Almicar Azevedo, Conjunto Eduardo Gomes, Bairro Rosa Elze, na cidade de São Cristóvão, com extensão de 10,3 Km até o Terminal do Distrito Industrial - DIA, situado na Av. Pref. Heráclito G. Rollemberg, Inácio Barbosa, na cidade de Aracaju (Figura 3).

Figura 3: Percurso realizado com modo de transporte individual (bicicleta)

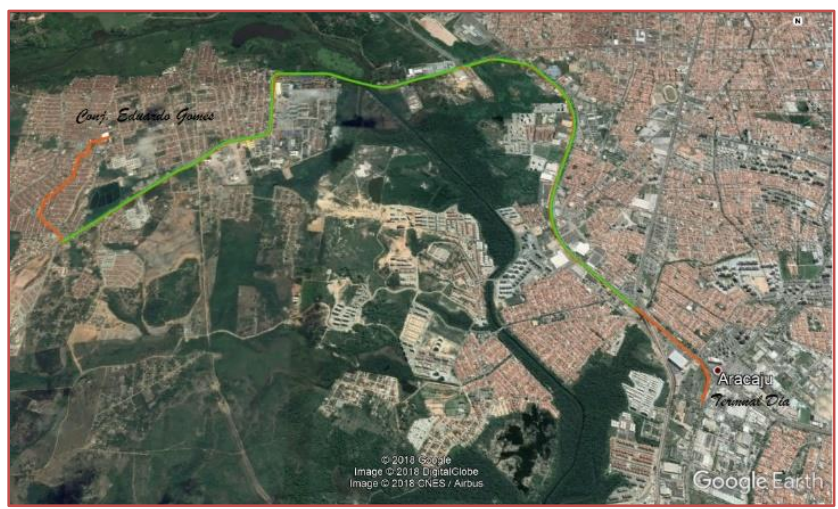

Fonte: Google Earth, 2018.

Descrição: trecho em verde corresponde a ciclovia.

A primeira viagem de bicicleta teve início as 7 h30min, horário com grande intensidade de tráfego. Uma parte do percurso, menor trecho, não possui ciclovia ou ciclofaixa obrigando o ciclista a dividir o espaço com outros veículos e muitas vezes com os pedestres.

O percurso foi realizado a partir da Rua José Almicar Azevedo passando pela Av. Marginal e Rua 64 sem a presença de nenhuma infraestrutura cicloviária, com buracos, desníveis e sem sinalização. A ciclovia tem seu início a partir da Av. João Bebe Água e segue pela Av. Marechal Cândido Rondon e finalizando na Av. Presidente Tancredo Neves, perfazendo $7 \mathrm{~km}$. A falta de faixa de pedestre para a travessia da Av. Presidente Tancredo Neves para a Av. Prefeito Heráclito Rollemberg dificulta o trajeto, pois 05 min do tempo do percurso foi destinado a espera para essa travessia. A viagem alcançou seu destino final às 8h10min57seg. tendo uma duração de 40min57seg.

A segunda viagem foi realizada no mesmo dia as $18 \mathrm{~h}$ sendo utilizado o mesmo percurso, alcançando seu destino final as $18 \mathrm{~h} 37 \mathrm{~min} 55 \mathrm{seg}$, com duração de $37 \mathrm{~min} 55 \mathrm{seg}$. A viagem à noite teve as mesmas características da manhã, porém não houve necessidade de espera para travessia da Av. Presidente Tancredo Neves para a Av. prefeito Heráclito Rollemberg. Vale ressaltar que a insegurança causada pela violência torna difícil a realização principalmente à noite, o medo predomina.

Foi observado durante a viagem que 02 (dois) fatores são determinantes para o uso da bicicleta, o primeiro é o estado da ciclovia que precisa ser melhorado e ampliado, o segundo é a questão da segurança em modo geral, por conta dos assaltos ou da falta de respeito dos motoristas e dos pedestres que muitas vezes preferem transitar na ciclovia a usar a calçada, principalmente no trecho que inicia na Av. João Bebe Água e segue pela Av. Marechal Cândido Rondon, especificamente até a Universidade Federal de Sergipe, onde o fluxo de pedestre é intenso. Nota-se também que a sinalização é deficiente dificultando dessa forma o deslocamento.

O sistema cicloviário necessita ser revisto, com ampliação das ciclovias, ciclofaixas e passeios compartilhados, de acordo com padrões para tipo de infraestrutura, adequadamente equipado com bicicletário e paraciclos, combinado à política pública de incentivo ao uso de bicicletas, integrado aos demais modos de transporte, contribuindo para a mobilidade urbana de Aracaju, que tem boas condições 
para o transporte por bicicleta, devido à sua configuração topográfica, com extensas áreas planas e poucas áreas elevadas.

\subsection{PERCURSO REALIZADO COM TRANSPORTE URBANO PÚBLICO (ÔNIBUS)}

0 transporte coletivo tem grande importância no contexto geral do transporte urbano. Ele é uma alternativa para redução das viagens por automóveis, contribuindo dessa forma para a redução dos congestionamentos e da poluição. Entretanto, a insatisfação dos usuários desse modo é alta, e em Aracaju não é diferente.

O levantamento de dados com o uso do transporte público foi realizado em 19 de abril de 2018, o qual teve início na Rua José Almicar Azevedo, Conjunto Eduardo Gomes, Bairro Rosa Elze, na cidade de São Cristóvão, com extensão de 12,1 Km até o Terminal do Distrito Industrial - DIA, situado na Av. Pref. Heráclito G. Rollemberg, Inácio Barbosa (Figura 4).

Figura 4: Percurso a pé juntamente com o transporte coletivo.

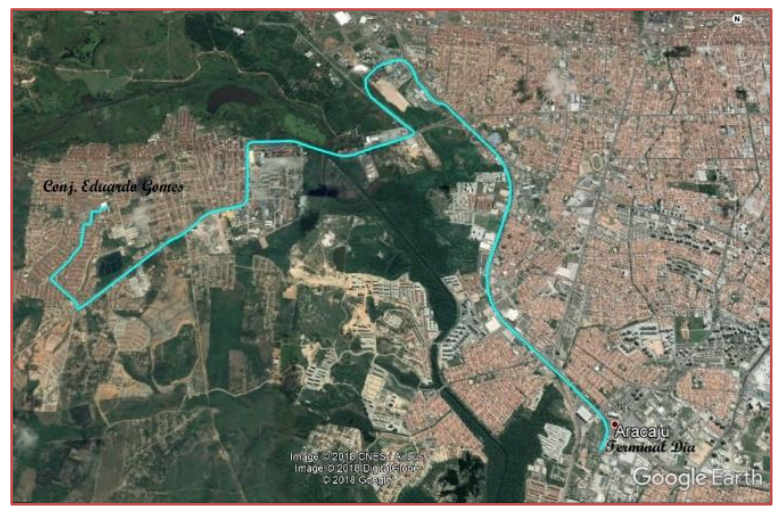

Fonte: Google Earth, 2018.

A primeira viagem teve início as $7 \mathrm{~h} 30 \mathrm{~min}$, uma pequena parte do percuso foi realizada a pé, onde foram percorridos aproximadamente $405 \mathrm{~m}$ até a parada de ônibus, esse percurso teve a duração de $05 \mathrm{~min} 49$ seg. Durante o trajeto observou-se que não existem calçadas em vários pontos, quando existem estão danificadas ou não oferencem acessibilidade.

A espera no ponto do ônibus foi breve com duração de $02 \mathrm{~min} 07 \mathrm{seg}$, o ponto apresentava uma cobertura precária e sem nenhum tipo de informação sobre linhas/itinerários e horários. 0 percurso do ponto de ônibus até o terminal Campos e o transbordo teve a duração de $04 \mathrm{~min} 02 \mathrm{seg}$, e ocorreu de forma tranquila, com quase todos os usuários acomodados. 0 resto do trajeto entre o terminal Campos e o terminal DIA, apresentou superlotação, lentidão e insegurança. A viagem alcançou seu destino final às $7 \mathrm{~h} 44 \mathrm{~min} 58 \mathrm{seg}$, com duração final de 44min58seg.

0 segundo percurso a noite teve início as $18 \mathrm{~h}$, tempo a pé até o ponto de ônibus foi de $05 \mathrm{~min} 43 \mathrm{seg}$, percurso com as características citadas no percurso da manhã. 0 tempo de espera no ponto de ônibus foi 07min36seg, o tempo de viagem dentro do ônibus até o terminal Campus novamente trânquilo, com a maioria dos passageiros acomodados.

A integração de um ônibus para outro no terminal Campus teve uma duração de 06min00seg, porém o tempo de viagem dentro do ônibus até o terminal DIA, mais uma vez péssimo, super lotado, vários pontos de parada, insegurança, a duração da viagem foi de $29 \mathrm{~min} 52 \mathrm{seg}$, chegando ao destino final, o Terminal do Distrito Industrial - DIA, situado na Av. Pref. Heráclito G. Rollemberg, Inácio Barbosa, as 18h49min11seg, com duração final de $49 \mathrm{~min} 11 \mathrm{seg}$.

O serviço de transporte público prestado a população é precário, com ônibus sucateados, quantidade insuficiente e que disputam espaço em vias congestionadas com os transportes individuais. É evidente que com a implantação da faixa exclusiva para os ônibus o trajeto melhorou um pouco, tornando as viagens para muitos aracajuanos alguns minutos mais rápidas. 
Na Figura 5 observa-se a compatibilização dos trajetos, onde pode-se verificar que o trajeto realizado pelo transporte público é maior, por conta dos terminais de integração, nesse caso, passando pelo terminal de integração Albino Fonseca (Zona Oeste), situado no bairro Novo Paraíso.

Figura 5: Compatibilização dos percursos

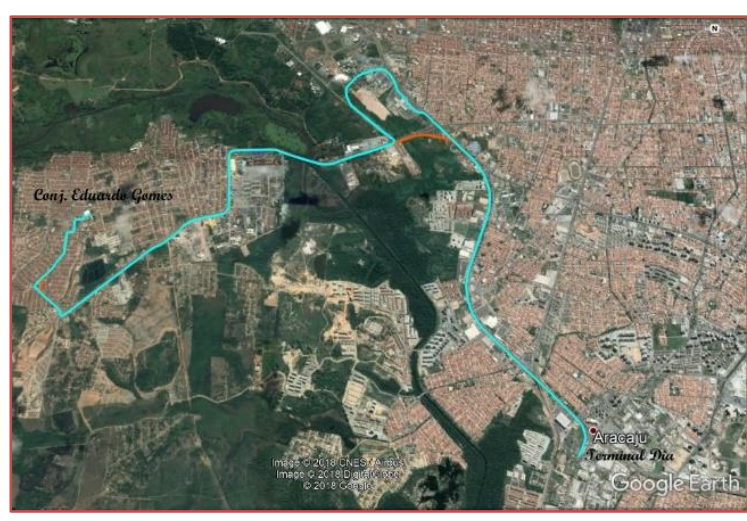

Fonte: Google Earth, 2018.

Para que as pessoas possam utilizar mais o transpote público é necessário que se faça algumas mudanças, pois acaba sendo uma viagem insegura por conta dos assaltos, desconfortáveis, pois a maior parte do percurso se faz em pé por conta da superlotação, viagem lenta, os ônibus apresentam má conservação, os pontos de parada não há informaçães e a infraestrutura viária também precisa de atenção.

De acordo com o PDMA (2015), a proposta para o transporte público coletivo em Aracaju refere-se à implantação do BRT (Bus Rapid Transit). O BRT se define como um sistema de transporte público coletivo de alta capacidade será composto por diversos de serviços que formatam uma rede com diferentes linhas caracterizadas como troncais, alimentadoras, interbairros, circulares e integradas; operadas por veículos específicos para cada tipo de linha; com as linhas troncais circulando com prioridade nos fluxos viários; com a utilização de novas tecnologias para o controle da operação do sistema.

No entanto, em 2016 a prefeitura de Aracaju decidiu abortar o BRT, conforme informações do superintendente da Superintendência de Transporte e Trânsito (SMTT), Aristóteles Fernandes. Chegou à conclusão que o BRT "não cabe" na cidade, mas manterá os ônibus articulados e também as faixas exclusivas para os ônibus do sistema de transporte público. Como continuam em vigor, serão multados os motoristas de veículos de passeio que insistirem em transitar pelas vias exclusivas para o transporte público.

Outra ação fundamental citada pelo PDMA (2015) refere-se à implantação de um novo regulamento da prestação do transporte coletivo público por ônibus, que compreenderá a reformulação do sistema existente, com o estabelecimento de um novo modelo contratual e institucional, considerando a operação dos serviços.

\subsection{ANÁLISE COMPARATIVA ENTRE MODOS DE TRANSPORTE}

Analisando os dados obtidos, no período da manhã, tendo o carro e a bicicleta percorrido 10,3 Km e o ônibus 12,1 Km, Observa-se que para chegar até o destino final o Terminal do Distrito Industrial - DIA, situado na Av. Pref. Heráclito G. Rollemberg, Inácio Barbosa, o carro obteve um tempo de 15min29seg, sendo o menor tempo, seguido da bicicleta com 40min57seg e por último o ônibus com um tempo de $44 \min 58$ seg.

No período da noite, perfazendo o mesmo percuso o carro obteve um tempo de $20 \mathrm{~min} 43 \mathrm{seg}$, sendo o menor tempo, seguido da bicicleta com $37 \mathrm{~min} 55 \mathrm{seg}$ e por último o ônibus com um tempo de $49 \mathrm{~min} 11 \mathrm{seg}$.

Cada um dos modais apresentou os prós e contras analisados durante o trajeto. Algumas das vantagens do uso carro é a flexibilidade de horário, tempo de viagem reduzido, conforto, privacidade, segurança contra violência, liberdade de parada durante o trajeto. Os contras mais evidentes foram os congestionamentos, custo da viagem, por conta do preço da gasolina e o grande índice de poluição. 
Com a viagem realizada de bicicleta adquire-se economia, tem flexibilidade nos horários, não polui, faz bem à saúde. Como alguns contras temos o tempo de viagem, para grandes distâncias acaba sendo inviável o uso da bicicleta, pois se torna uma viagem cansativa causando o desconforto, insegurança tanto relacionado à violência quanto aos acidentes, além do usuário está exposto aos intemperes climáticos.

Em relação ao transporte público as vantagens vistas ao utilizar esse modo são as reduções de engarrafamento, podendo transportar várias pessoas ao mesmo tempo, dessa forma, gerando menos poluentes, é modo econômico comparado ao uso do carro. Como nos outros modos também apresenta as desvantagens dessa viagem como a violência, pessoas vulneráveis a assaltos tanto dentro do transporte quanto no caminho até o ponto de ônibus, superlotação, tempo de espera e tempo de viagem, falta de condições como ônibus danificados e a inflexibilidade dos horários.

O transporte público urbano possibilita transportar várias pessoas ao mesmo tempo, são pertencentes a empresas ou concessionarias. Os horários e itinerários não são flexíveis, são prefixados. Normalmente existe a necessidade de completar as viagens com percursos a pé, ou em outros modos, a quantidade de passageiros quase nem sempre atinge a quantidade máxima (FERRAZ e TORRES, 2004).

\subsection{O USUÁRIO E O TRANSPORTE URBANO}

Analisando os dados colhidos através de entrevistas no centro da cidade, Faculdade Pio X, Shoppings Jardins e Riomar, foi utilizada uma amostragem de 166 pessoas questionadas sobre os modos de transporte na grande Aracaju. Inicialmente foi necessário fazer um perfil do entrevistado. A distribuição por faixa etária dos 166 entrevistados demostra que $47,0 \%$ estão na faixa de 30 a 49 anos, seguido por $42,8 \%$ na faixa dos 18 a 29 anos e $10,2 \%$ tem acima dos 50 anos.

Com relação ao grau de escolaridade, 34,4\% dos entrevistados têm o ensino médio completo, $25,6 \%$ têm ensino superior incompleto, $21,3 \%$ ensino superior completo, $7,5 \%$ estão inclusos com pós graduação, mestrado, ensino técnico e os que optaram em não responder, 5,6\% ensino fundamental completo, 3,1\% ensino médio incompleto, 2,5\% ensino fundamental incompleto. A maioria dos entrevistados possuem nível médio de estudo.

Quanto ao gênero dos entrevistados, a maioria dos entrevistados foram do sexo feminino, uma porcentagem de $57,2 \%$ e $42,8 \%$ do sexo masculino. Foi constatado que $33,1 \%$ dos entrevistados moram na zona Norte, $30,1 \%$ na Zona Sul, $18,7 \%$ na Zona Oeste, $12,7 \%$ no Centro e por último $5,4 \%$ na Zona Leste.

Em grandes municípios, as pessoas se deslocam em massa de onde moram para onde trabalham, estudam, compram e tem seu lazer. Se estes locais são distantes entre si, impossibilitam o deslocamento a pé, motivando a necessidade do uso de meios de transporte individual ou coletivo. A escolha entre cada uma delas, seja pelo usuário, seja pela coletividade, vai depender de diversos fatores: distância a percorrer, tempo disponível, conforto desejado e disponibilidade de recursos para que se tenha o equipamento adequado (OLIVEIRA JUNIOR, 2017).

Foi constatado que $57,8 \%$ dos entrevistados possuem veículo próprio e $42,2 \%$ não possuem, necessitando assim de outro modo de transporte para realizar o deslocamento, onde a tabela 5 buscou identificar quais são os modos mais utilizados, os dados indicam que 50,0\% dos entrevistados utilizam transporte privado como carro ou moto todos os dias e $41,6 \%$ utilizam o ônibus e $8,4 \%$ são os que utilizam outros modos, como a bicicleta, a pé e o lotação. Esse resultado mostra que a maioria das pessoas que não possuem o carro circula de ônibus.

Dentre o universo da pesquisa os usuários têm como objetivo principal ao uso do transporte: $69,9 \%$ usam para trabalho, 21,7\% para escola/universidade, 3,6\% para lazer e $4,8 \%$ utilizam para outras atividades (Figura 6). 
Figura 6: "Qual objetivo principal ao uso do transporte?"

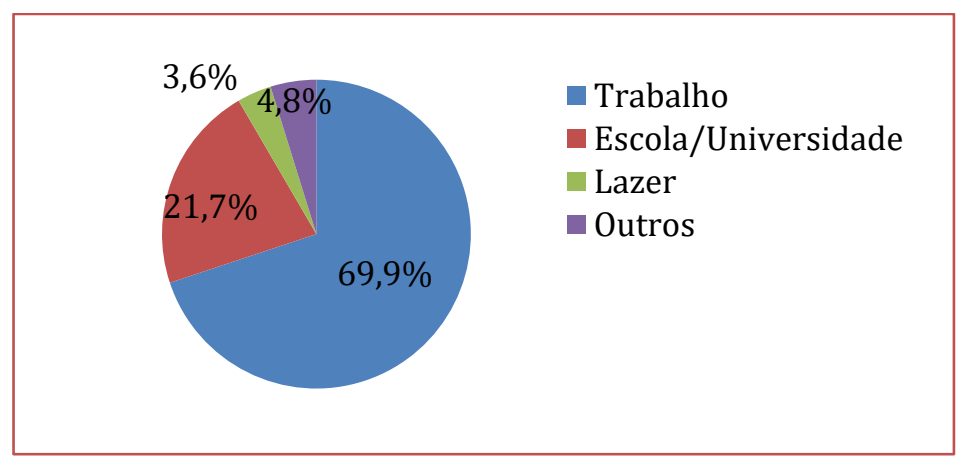

Fonte: autor, 2018.

O tempo médio de deslocamento para a atividade principal (ida e volta) foi de $38,0 \%$ de 0 a 30 min e de 30 a $60 \mathrm{~min}$, e $12 \%$ de 60 a $90 \mathrm{~min}$ e de 90 a $120 \mathrm{~min}$. Dentre os usuários entrevistados 51,8\% responderam que nunca tentaram realizar o percurso para a atividade principal utilizando outro modo de transporte.

\subsubsection{AVALIAÇÃO DO TRANSPORTE PÚBLICO}

Os ônibus permitem ainda o deslocamento de indivíduos de baixa renda que não tem condições de comprar seu próprio veículo e uma importante possibilidade para quem não pode dirigir, tais como adolescentes, além é claro da inclusão social que esse veículo possibilita que qualquer cidadão circule pela cidade (OLIVEIRA JUNIOR, 2017).

De acordo com os entrevistados $42,2 \%$ utilizam o ônibus de vez em quando, 23,5\% utilizam todos os dias, $14,5 \%$ quase todos os dias e 19,9\% do entrevistados nunca utilizam o transporte público. Esse resultado se deu pelo fato das entrevistas não terem acontecido nos pontos de ônibus e sim em locais de acesso com vários modais.

A insatisfação também estar presente no que se diz respeito à limpeza, conservação e manutenção dos terminais e das estações de transbordo onde $43,9 \%$ responderam que estão em péssimas condições, $40,9 \%$ ruim, $13,6 \%$ bom e 1,5\% responderam ótimo. Essa questão além de ser competência dos governantes é necessário que os usuários se conscientizem e promova a conservação, zelando pelo patrimônio, sem vandalismo.

A duração das viagens também não agrada aos usuários onde 49,2\% avaliaram como ruim, 31,8\% como bom, 17,7\% com péssima duração e 1,5\% avaliaram como ótimo. Em relação à pontualidade 48,5\% avaliaram negativamente respondendo ruim, $35,6 \%$ avaliaram positivamente respondendo bom, $11,4 \%$ como péssima e $3 \%$ avaliaram como ótimo. Esse resultado mostra o quão difícil é depender desse modo de transporte, principalmente para as atividades com horário marcado.

"Para o passageiro, a melhor condição aconteceria quando ele dispusesse de pontos de parada próximos aos locais de origem e destino de seus deslocamentos e contasse com frequência adequada de serviço" (CARDOSO, 2008, p.21).

Quanto a valiação dos usuários de acordo com o grau de satisfação, nota-se que a maioria está insatisfeito com o serviço de transporte público (Figura 7). Observa-se que para $47,7 \%$ dos entrevistados são ruins as condições gerais do ônibus, $28,0 \%$ avaliaram como péssimo, 22,7\% como bom e 1,5\% como ótimo. 
Figura 7: Avaliação do grau de satisfação do usuário de transporte público

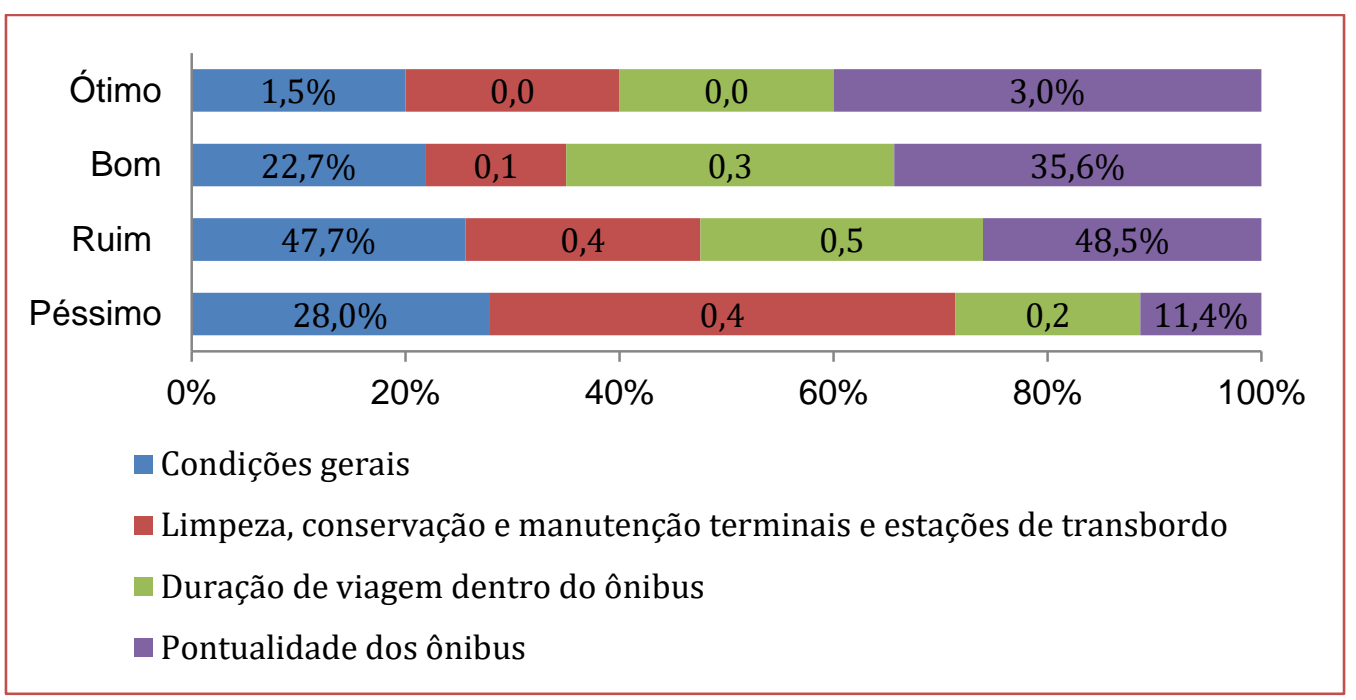

Fonte: autor, 2018.

O sistema de informação mostra sua ineficiência através da avaliação dos usuários, onde, 44,7\% avaliaram como ruim $33,3 \%$ como péssimo e $22,0 \%$ como boa, impossibilitando os usuários a fazer suas reclamações sobre o serviço de transporte público.

Os usuários também avaliaram a acessibilidade, onde 84,6\% classificam como ruim ou péssima e 19,70\% como boa. Quanto ao comportamento dos motoristas e cobradores $74,2 \%$ dos usuários estão satisfeitos, $62,9 \%$ avaliaram como bom, $8,3 \%$ como ótimo, 3,0\% como excelente e $25,7 \%$ estão insatisfeitos, onde $22,7 \%$ avaliaram como ruim e $3,0 \%$ como péssimo.

Como pode ser observada, a maioria dos entrevistados com 90,9\% dos usuários não se sentem seguros na viagem, sendo que, $60,6 \%$ avaliaram como péssima a segurança, 30,3\% como ruim e 9,1\% se sentem seguros (Figura 8).

Figura 8: Avaliação do grau de satisfação usuário de transporte público

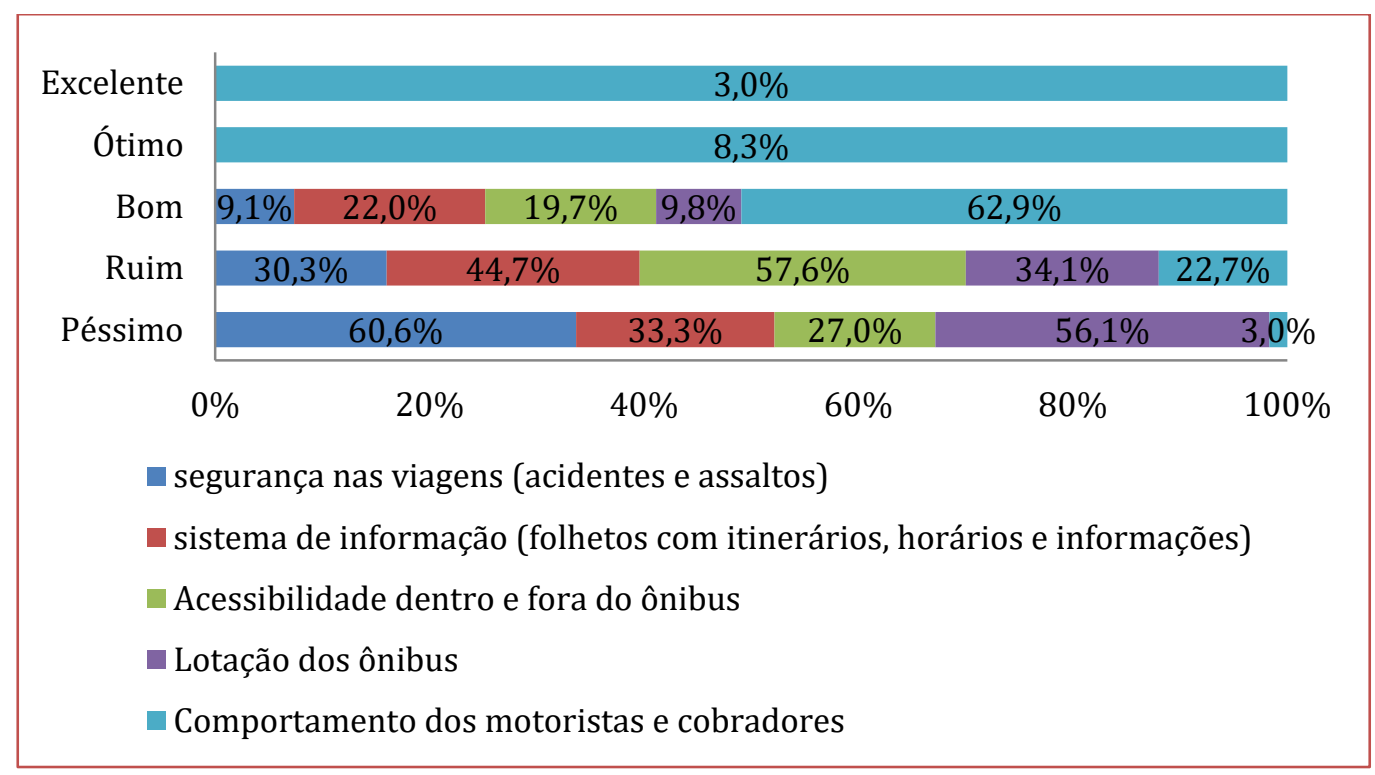

Fonte: autor, 2018.

Para Cardoso (2008), quanto menos o usuário anda a pé, melhor é acessibilidade ao sistema de transporte público. Mas não apenas levando em conta a distância percorrida, a acessibilidade de um sistema de 
transporte público de passageiros pode ser caracterizada pela maior ou menor facilidade de acesso ao sistema, sendo proporcional ao tempo decorrido até o ponto de parada e o tempo de espera pelo veículo.

Para $60,6 \%$ dos usuários à faixa exclusiva para ônibus melhorou um pouco a viagem, enquanto para 25,8\% não melhorou, 9,8\% que melhorou muito e 3,8\% piorou (Figura 9).

Figura 9: Avaliação da faixa exclusiva para ônibus

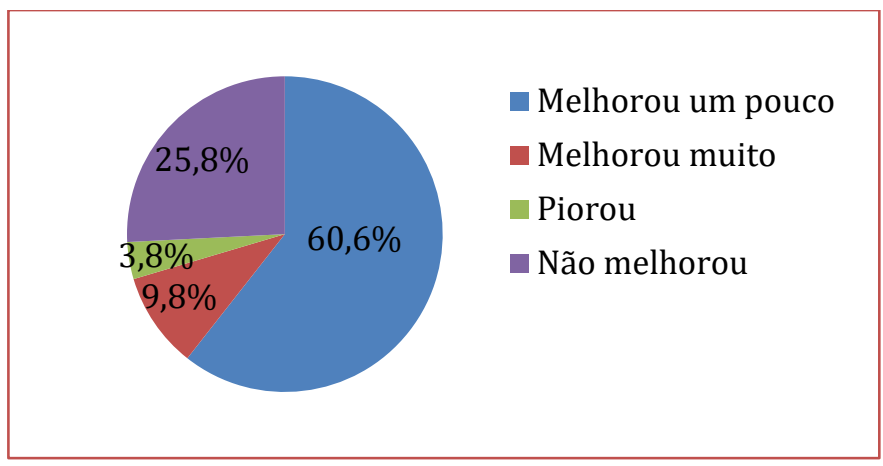

Fonte: autor, 2018.

De acordo com esses resultados é necessário que as autoridades reavaliem os ônibus utilizados para o transporte da população, pois os usuários desse modo se deparam diariamente com várias situações que dificultam o seu deslocamento.

De acordo PDMA (2015) para estabelecer as prioridades de circulação do transporte de massa em relação ao transporte individual implicará na estruturação do sistema viário, sendo de fundamental importância, pois define corredores e requerem a apropriação do espaço viário para o trânsito dos ônibus das linhas troncais que podem ser em canaletas exclusivas ou faixas exclusivas, posicionadas no centro da via, à direita ou à esquerda do sentido de circulação dos veículos.

\subsubsection{AVALIAÇÃO DO TRANSPORTE PRIVADO}

A avaliação do transporte privado mostrou que 38,4\% dos usuários utilizam esse modo todos os dias, $31,1 \%$ nunca utilizam, $24,4 \%$ quase todos os dias e $6,1 \%$ dos entrevistados nunca (Figura 10). A principal dificuldade encontrada para o deslocamento desses usuários são os congestionamentos (52,6\%), seguida da educação dos condutores $(23,7 \%)$, falta de estacionamentos $(16,7 \%)$, falta de rotas alternativa $(3,5 \%)$ e finalizando com outras situaç̧ões $(3,5 \%)$.

A precedência da circulação motorizada e individual traz reações, por vezes negativos, ao ambiente urbano. A verdade encontrada em grandes partes das cidades no Brasil é a de vias lotadas, incapazes de concentrar, com eficácia, o aumento dos fluxos, comprometendo a qualidade na operação dos modos de transporte (ALVES, 2015).

Figura 10: Frequência da utilização do transporte privado

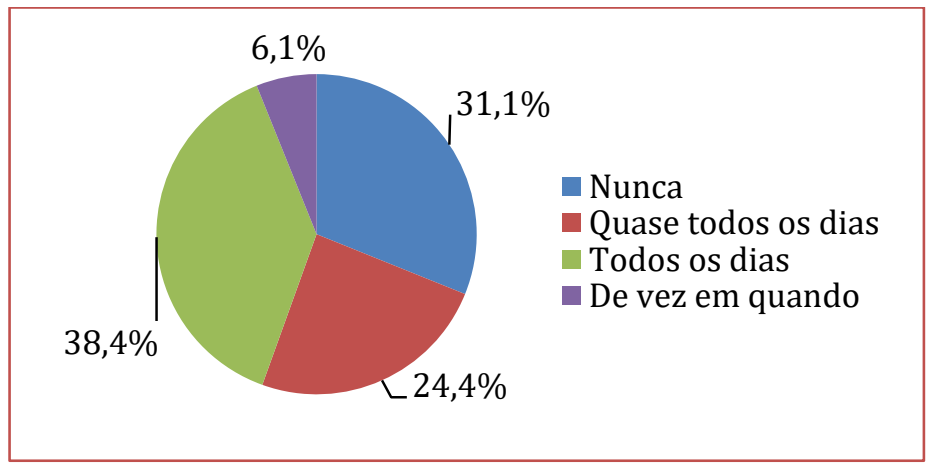

Fonte: autor, 2018. 
Quando questionados sobre o motivou para a escolha do modo privado, 36,3\% responderam que a segurança, seguindo de 30,1\% respondendo o conforto, 23,0\% a rapidez, 7,1\% a privacidade e 3,5\% responderam que o status conforme (Figura 11). Quanto à avaliação sinalização de trânsito, 67,6\% dos entrevistados classificaram como boa. A segurança e o conforto, levantados na pesquisa pode-se dizer que são a cultura do carro, em que a maior parte prefere utilizar o carro como meio de transporte ao invés do transporte público coletivo.

Figura 11: “Qual motivo para a escolha do carro/moto como meio de transporte?"

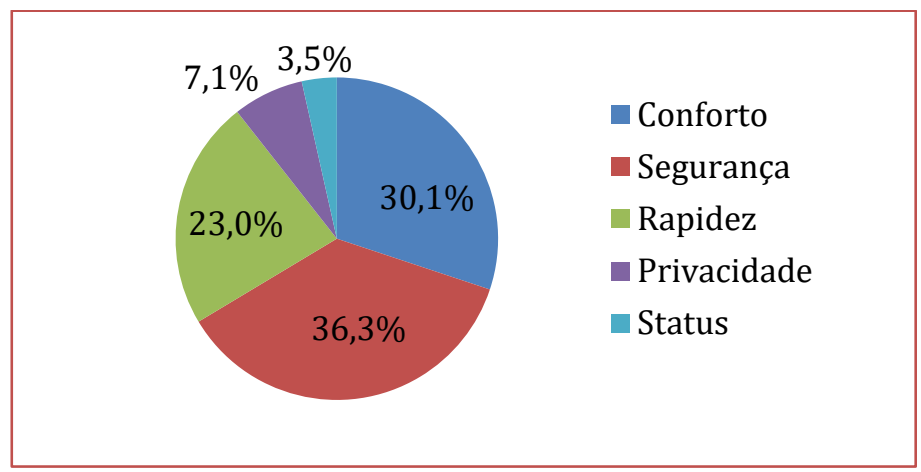

Fonte: autor, 2018.

Ferraz e Torres (2004) destacam que com o Transporte Urbano Privado ou Individual as viagens são realizadas em qualquer horário e qualquer percurso, ou seja, tem ótima flexibilidade, menor tempo de viagem, as viagens não precisam ser completadas, além de proporcionar maior conforto.

Como pode observar, 54,1\% dos usuários de carro não utilizam o transporte público pela falta de segurança, 31,2\% pelo tempo da viagem, que é bem maior, 8,3\% pela falta de conforto, 4,6\% não citaram qual motivo e 1,8\% o custo da passagem. Esse resultado vem de acordo com o resultado dos usuários de transporte público ondem a maioria respondeu que não se sente seguros na viagem.

Quando questionados sobre as emissões de poluentes, 79,5\% dos entrevistados disseram que acham importante, $18,8 \%$ nunca pensaram no assunto e 1,8\% disseram que é uma questão como irrelevante. Além da poluição atmosférica, os ruídos no trânsito vêm colaborando progressivamente para que as pessoas passem a ser frustradas e se sintam desestimuladas a saírem de suas casas. Dessa forma, argumenta qual seria o melhor caminho para se alcançar a mobilidade urbana e a sustentabilidade (VASCONCELOS, 2014).

\subsubsection{AVALIAÇÃO DO TRANSPORTE POR BICICLETA}

A avaliação do transporte por bicicleta mostrou que 68,1\% não utilizam esse modo para deslocamento e $31,9 \%$ utilizam, sendo que $4,2 \%$ utilizam todos os dias (Figura 12). E o que mais motivou para a escolha desse modo, $54,5 \%$ respondeu por ser mais saudável, $20 \%$ pela rapidez, $18,2 \%$ pelo baixo custo, 3,6\% por ser não poluentes e 3,6\% pela sensação de liberdade.

Figura 12: Frequência da utilização do transporte por bicicleta

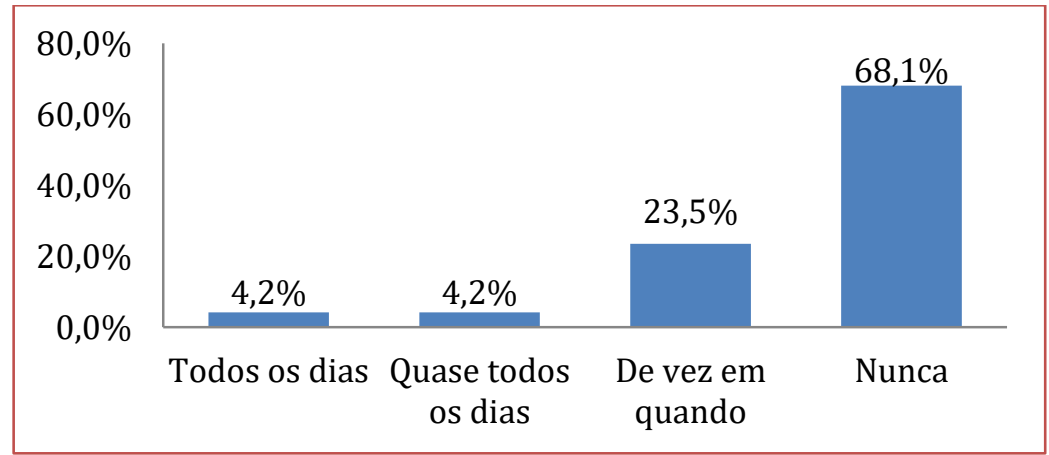


Fonte: autor, 2018.

Oliveira Junior (2017) destaca que os sujeitos terminam não usando a bicicleta pela insegurança, risco apresentado, falta de espaços apropriados. A bicicleta é um veículo que não afeta o meio ambiente e as condições humanas decorrentes. Além do mais, pode ser vista como recurso democrático de oferta de transporte para a população, pois integra, confere o direito de trafegar de uma maneira saudável, ecologicamente correta e com baixo custo.

0 uso das bicicletas, além dos benefícios energéticos e ambientais, apresenta muitas características favoráveis a sua utilização, como por exemplo: o baixo custo de aquisição e manutenção, dentre os demais modos à bicicleta é o meio mais barato, a flexibilidade por ser acessível a lugares onde outros modos de transporte não podem circular, a exemplo do congestionamento, rapidez, a bicicleta é o meio de transporte mais rápido em deslocamentos "porta a porta" e o menor necessidade de espaço público, tanto no deslocamento quanto no estacionamento (MINISTÉRIO DAS CIDADES, 2007).

A maioria dos entrevistados com 42,6\% avaliaram como boa às condições das ciclovias e 48,2\% avaliaram também como boa a infraestrutura cicloviária da cidade. Para os usuários, o maior problema enfrentado na realização da viagem é a segurança (32,7\%), seguido do comportamento dos condutores $(30,9 \%)$, falta de ciclovia $(23,6 \%)$, a falta de sinalização $(9,1 \%)$ e não responderam $(3,7 \%)$.

Os ciclistas estão entre os usuários mais vulneráveis das ruas, além das suas bicicletas estarem sujeitas ao roubo. Para que se promova o uso da bicicleta é necessário que haja condições seguras para sua circulação. De acordo com Celes (2009), o uso de bicicletas deve ser incentivado como um meio de transporte diário e associado à rede de transporte público, como também, na forma de alternativa de lazer, que provoca a habilitação dos órgãos gestores municipal, a elaboração e implantação de redes cicloviárias e de adaptação do sistema viário e equipamentos de estacionamento para integração com a rede de transporte público.

\subsubsection{AVALIAÇÃO DO TRANSPORTE A PÉ}

A avaliação do transporte a pé mostrou que $63 \%$ dos entrevistados se locomovem a pé, sendo $43,2 \%$ de vez em quando, $6,2 \%$ quase todos os dias e $13,6 \%$ todos os dias, $37 \%$ nunca (Figura 13 ).

Figura 13: Frequência da utilização do transporte a pé

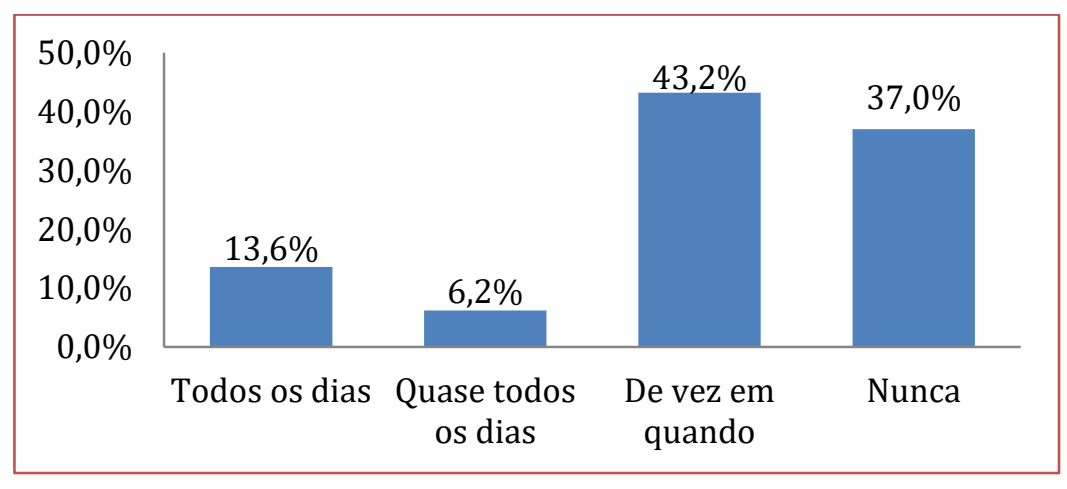

Fonte: autor, 2018.

Dos sujeitos que se locomovem a pé, $62,8 \%$ responderam o que mais motivou para a escolha desse meio de transporte foi à proximidade. Outro ponto abordado foi às faixas de pedestres, $81 \%$ responderam que a quantidade de faixa é insuficiente e $91,5 \%$ disseram que os motoristas não respeitam (Figura 14). 0 pedestre precisa ser prioridade frente ao fluxo de veículos, bem como haver sinalização visível, deve-se implantar padrões levando em consideração as condições de trafegar pelas calçadas. 
Figura 14: Faixa de pedestres e respeito dos motoristas

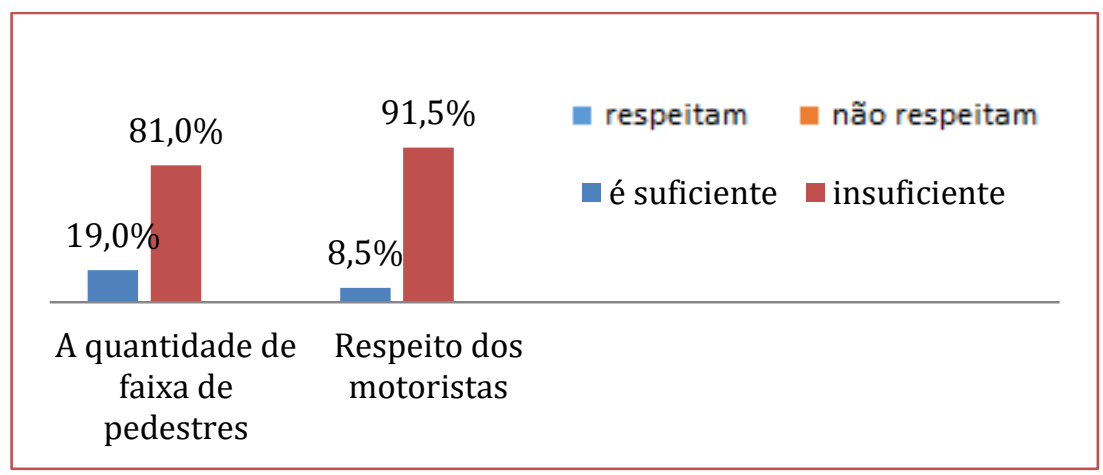

Fonte: autor, 2018.

Quando questionados sobre a situação das calçadas e praças, 79,2\% dos usuários mostra a insatisfação, onde $43,4 \%$ avaliaram como ruim e 35,8\% como péssima. Essa realidade mostra a necessidade de investimentos dos espaços públicos (calçadas) de uma forma prioritária, pois é o lugar próprio para a circulação de pedestre.

Como em qualquer cidade de países em desenvolvimento, a falta de conforto e de segurança para caminhar tem sido um dos maiores problemas para os pedestres. Há muitas barreiras instaladas nos passeios públicos, dentre materiais para obras da construção civil, carros, motos, comércio ambulante, elementos que restringem a acessibilidade aos principais equipamentos públicos tanto para pessoas com mobilidade reduzida, como para os pedestres que não sofrem nenhuma restrição física (OLIVEIRA JUNIOR, 2017).

\section{CONSIDERAÇõES FINAIS}

A crescente expansão e popularidade do modo de transporte individual e motorizado, principalmente de automóveis, é um dos graves problemas que atinge grande parte das cidades brasileiras, isso não é diferente em Aracaju. A rápida expansão e popularidade desses modais repercutiram de forma negativa nos espaços urbanos que passaram a adequar-se as necessidades desses modos de transporte em desvantagem para uma circulação não motorizada e para o transporte público que passaram a operar em segundo plano, resultando uma baixa na qualidade de vida, na sustentabilidade e na inclusão socioespacial.

Projetos tidos como sustentáveis são os que compõem a ecologia, a economia e o social, que garanta a eficácia econômica e a proteção do meio ambiente, sem que desapareçam os objetivos sociais que são a luta contra a pobreza, contra as desigualdades e contra a exclusão.

O município de Aracaju foi e continua sendo planejado de forma a contemplar os modos motorizados e individuais resultando nas dificuldades que os cidadãos têm ao se deparar diariamente com situações que dificultam seu deslocamento, como: a falta segurança, congestionamentos, ineficiência do transporte público coletivo (ônibus), inexistência de ciclovias, insuficiência de estudo para geração de tráfego e falta de acessibilidade, são alguns dos fatores que tem prejudicado sua mobilidade urbana.

Diante disso, observa-se que a falta de planejamento e investimentos dos setores competentes tem trazido grandes prejuízos à população mostrando dificuldades nos deslocamentos para as atividades principais. E para que haja mudança necessária, e a sustentabilidade realmente aconteça, é preciso priorizar e incentivar o uso do transporte coletivo e o uso da bicicleta.

No entanto um trânsito sustentável não é só responsabilidade do poder público, deve partir também de seus usuários, pois suas decisões, como por exemplo, a escolha do automóvel, a regularidade da manutenção, a disponibilidade de compartilhar o carro com pessoas com trajeto em comuns, podem fazer a diferença, por fim, educação é essencial para um transito mais sustentável. 


\section{REFERÊNCIAS}

[1] ARACAJU, Lei n. 13 de 03 de junho de 1966, Institui o Código de Obras do Município e dar outras providências. Câmara Municipal de Aracaju. Disponível em: <http://www.aracaju.se.gov.br/userfiles/seplan/arquivos/planodiretor/COD_OBRAS.pdf>. Acesso em 28 mar. 2018.

[2] _. Ministério Das Cidades, 2007, Plano de Mobilidade por Bicicleta nas Cidades, Coleção Bicicleta Brasil, caderno 1, Secretaria Nacional de Transporte e da Mobilidade Urbana, Brasília. Disponível em: <https://www.cidades.gov.br/images /stories/ArquivosSEMOB/Biblioteca/LivroBicicletaBrasil.pdf>. Acesso em: 09 mar. 2018.

[3] _ Ministério Das Cidades. Plano Diretor Participativo: guia para a elaboração pelos municípios e cidadãos. Brasília: CONFEA, 2004. 158 p. Disponível em: http://polis.org.br/wp-content/uploads/Plano-DiretorParticipativo-1.pdf. Acesso em: 27 mar. 2018.

[4] AFFONSO, Nazareno Stanislau et al. MOBILIDADE E QUALIDADE DE VIDA. Disponível em: <http://www.ruaviva.org.br>. Acesso em: 14 maio 2018.

[5] ALVES, Priscilla. MOBILIDADE URBANA SUSTENTÁVEL E POLOS GERADORES DE VIAGENS: análise da mobilidade não motorizada e do transporte público. 2015. 327 f. Tese (Doutorado) - Curso de Geografia, Instituto de Geografia, Universidade Federal de Uberlândia, Uberlândia, 2015. Disponível em: <https://repositorio.ufu.br/bitstream/123456789/16010/1/MobilidadeUrbanaSustentavel.pdf>. Acesso em: 05 mar. 2018.

[6] BANA e COSTA, C. A. Metodologias de análise de decisão. Lisboa: Instituto Superior Técnico, 2001.

[7] CARDOSO, Carlos Eduardo de Paiva. Análise do transporte coletivo urbano sob a ótica dos riscos e carências sociais. Tese de Doutorado, Programa de Pós-graduação em serviço social, Pontifícia Universidade Pontifícia Católica de São Paulo, São Paulo, 2000. Caderno de psicologia do trânsito e compromisso social. Brasilia, 2008.

[8] CELES, Debora Alves. MOBILIDADE SUSTENTÁVEL EM PEQUENAS CIDADES: o caso de Boa Nova/BA. 2009. 200 f. Dissertação (Mestrado) - Curso de Engenharia Ambiental Urbana, Universidade Federal da Bahia, Salvador, 2009. Disponível em: <http://www.ppec.ufba.br/site/publicacoes>. Acesso em: 13 mar. 2018.

[9] COSTA, Marcela da Silva; RAMOS, Rui Antônio Rodrigues e Silva, Antônio Nelson Rodrigues (2008). Um índice de Mobilidade Urbana Sustentável para cidades brasileiras.

[10] FERRAZ, Antonio Clóvis Pinto; TORRES, Isaac Guillermo Espinosa. Transporte Público Urbano. 2. ed. São Carlos: Rima, 2004. 428 p.

[11] GERHARD, Dra. Tatiana Engel; SILVEIRA, Dra. Denise Tolfo. Métodos de Pesquisa. Porto Alegre: Apostila, 2008. 121 p. Disponível em: <http://www.ufrgs.br>. Acesso em: 15 abr. 2018.

[12] INSTITUTO BRASILEIRO DE GEOGRAFIA E ESTATÍSTICA. IBGE Cidades. Rio de Janeiro, 2010. Disponível em: $<$ http://www.cidades.ibge.gov.br >.

[13] LAKATOS, Eva Maria; MARCONI, Marina de Andrade. Metodologia científica. 3.ed. São Paulo: Atlas, 2000.

[14] MENDES JUNIOR, DR., Ricardo; FUSCO, Rafael. PROJETO CARONA SOLIDÁRIA NA UFPR. Extensão em Foco, Curitiba, n. 8, dez. 2013. Disponível em: <http://revistas.ufpr.br/extensao/article/view/35664/22002>. Acesso em: 21 mar. 2018.

[15] OLIVEIRA JUNIOR, Ertal de Vasconcelos. Mobilidade Urbana Sustentável em Francisco Beltrão: Uma cidade de Porte médio do Paraná. 2017. 111 f. Dissertação (Mestrado) - Curso de Arquitetura e Urbanismo, Universidade do Vale do Rio Sinos - Unisinos, São Leopoldo, 2017. Disponível em: <http://www.repositorio.jesuita.org.br/handle/UNISINOS/6736>. Acesso em: 19 fev. 2018.

[16] VASCONCELOS, Alana Danielly. Aracaju sob Rodas: Aspectos da mobilidade Urbana no Viés do Transporte público. 2014. 112 f. Dissertação (Mestrado) - Curso de Desenvolvimento e Meio Ambiente, Universidade Federal de Sergipe, São Cristóvão, 2014. 


\section{Capítulo 2}

\section{Análise comparativa entre concreto armado convencional e concreto protendido na execução de edifício vertical residencial no município de Aracaju}

\section{Maria Andreza Santana Almeida \\ Hilderardi Mendonça de Melo \\ Iris Sterfanie Santos}

Resumo: A aplicação do sistema de protensão ganha espaço no Brasil de maneira pouco incisiva comparado ao concreto armado convencional. Há estereótipos estabelecidos no mercado com relação ao custo do sistema e acomodação da equipe técnica, projetistas ou gestores de obra, ou falta de conhecimento com a protensão. Esse trabalho tem como objetivo comparar a técnica convencional com o concreto protendido de uma edificação vertical residencial a partir do levantamento do quantitativo de material utilizado por ambas as estruturas e então avaliar a viabilidade construtiva para a substituição do concreto convencional pelo protendido. Os dados foram obtidos através do levantamento do quantitativo de material do projeto em concreto convencional existente e do projeto em protensão executado através do Adapt. Após o levantamento os dados foram distribuídos no Orse para obtenção dos custos de ambos os métodos. Contemplou-se na análise lajes, vigas e pilares do térreo, pavimento superior e seis pavimentos tipo. A partir dos resultados pode-se constatar redução de quantitativos de aço e concreto quando utilizado protensão e o custo global da estrutura em concreto convencional apresentou-se aproximadamente 3 vezes mais elevado. Em função dos dados obtidos infere-se a viabilidade para utilização do sistema com protensão nas construções residenciais, sobretudo quando é necessário garantir desempenho e conforto em termos arquitetônicos, bem como avanço na produtividade da obra de forma geral.

Palavras-chave: Concreto armado. Concreto protendido. Viabilidade técnico-econômica. 


\section{INTRODUÇÃO}

A busca por modernos métodos executivos está atrelada a variados fatores, como conforto arquitetônico e aceleração no processo de execução. Neste cenário encontra-se a técnica estrutural do concreto armado protendido em substituição do concreto armado convencional. Segundo a NBR 6118 (2014) estruturas em concreto protendido são aquelas em que parte das armaduras dos seus elementos estruturais são alongadas por equipamentos especiais, melhorando a exploração e rendimento dos aços de alta resistência no estado-limite último.

O sistema de laje protendida representa um dos avanços tecnológicos na construção civil. Entretanto, até os dias atuais, esta técnica é difundida em obras pesadas, como construções de pontes e viadutos e muitas vezes não se torna opção devido à falta de mão de obra qualificada para executar e gerir ou ainda pelo tradicionalismo do uso do sistema convencional (SCHMID M.T, 2009).

De acordo com Bastos (2018), uma peça só pode ser considerada de concreto protendido quando a mesma é submetida a ação de forças especiais e permanentes aplicadas, chamadas de forças de protensão, submetido a ação simultânea das cargas permanentes e variáveis e ainda assim o concreto não seja solicitado a tração apenas dentro dos limites permitidos.

A protensão pode ser pré-tracionada ou pós-tracionada. 0 concreto protendido pós-tracionado, ou seja, tracionado após o endurecimento do concreto, subdivide-se em sistema aderente e não-aderente. 0 aderente é caracterizado pela injeção de calda de cimento em bainhas que envolvem os fios (SCHMID M.R, 2007) (CASTR0,2011). A monocordoalha engraxada é um sistema não aderente, que se utiliza de uma graxa para envolver o cabo metálico (Souza e Macedo, 2016).

Schmid M.R (2007) determina estrutura de concreto utilizando a protensão como uma técnica inteligente, eficaz e duradoura. A técnica oferece ainda vãos com maiores autonomias entre pilares, controle da deformação e fissurações e lajes mais esbeltas. Desse modo, o presente trabalho tem o objetivo de comparar a técnica convencional com o concreto protendido a partir do quantitativo de material utilizado por ambas as estruturas durante sua construção e então avaliar a viabilidade construtiva para a substituição do concreto convencional pelo protendido.

\section{METODOLOGIA}

Para realização desse trabalho foram utilizados dois procedimentos: a pesquisa bibliográfica a respeito do sistema estrutural protendido em edifícios verticais através de artigos, monografias, dissertações, livros, revistas e sites acadêmicos, em seguida foi realizada a pesquisa documental, que consiste em analisar materiais de natureza diversas, valendo-se, no presente estudo, de projeto estrutural de edificação vertical fornecido pelo projetista estrutural com o intuito de extrair dados quantitativos para obtenção dos resultados.

0 presente trabalho foi desenvolvido em uma edificação residencial localizada no bairro Atalaia, município de Aracaju, estado de Sergipe (Figura 1). 
Figura 1: Mapa do Bairro Atalaia, Município de Aracaju e Estado de Sergipe

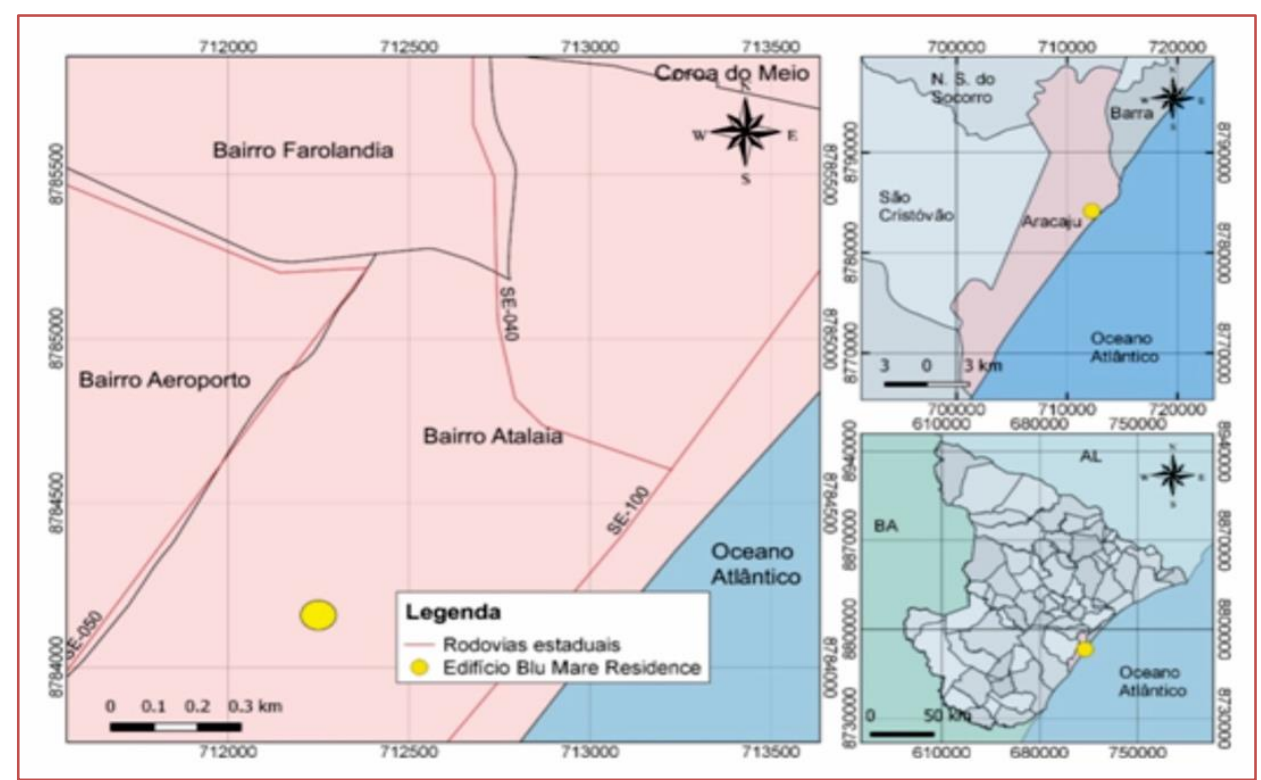

Elaborador: José Carlos Benicio do N. Filho DATUM: SIRGAS 2000

FONTE: SEMARH - 2016.

A coleta de dados foi realizada através do projeto arquitetônico e projeto estrutural convencional do condomínio Blu Mare Residence (Figura 2). 0 edifício é composto por oito pavimentos, onde sua distribuição, de interesse para analise, ocorre da seguinte forma: térreo garagem no sistema pilotis, primeiro pavimento composto por apartamentos, playground e piscina e demais pavimentos são tipo. A fundação foi executada através de blocos e estacas do tipo escavada com fluido estabilizante.

Figura 2: Corte Longitudinal do Edifício Blu Mare Residence

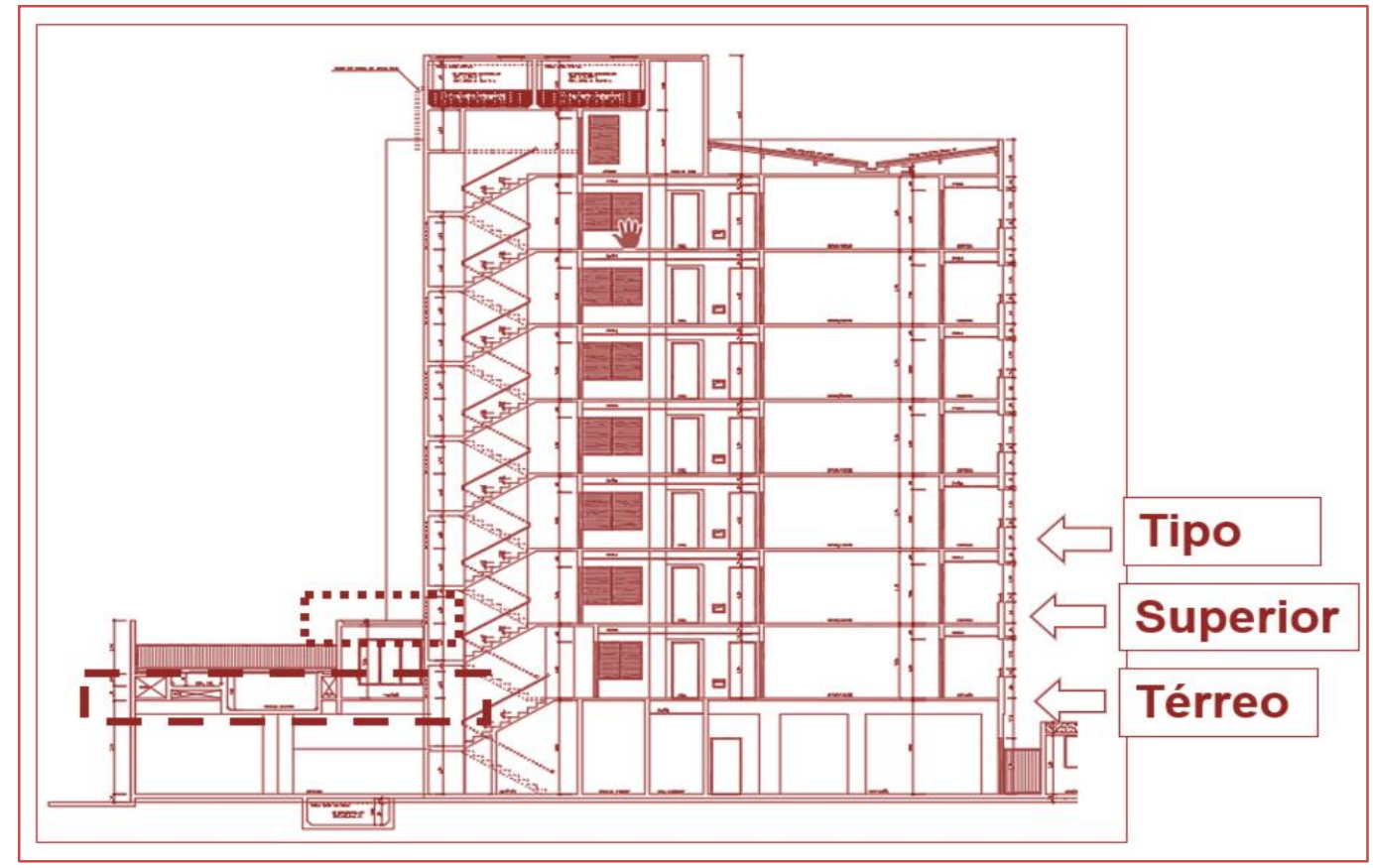

Fonte: Paulo Roberto Rehm Pereira (2012). 
Os projetos estruturais foram analisados de forma individual para cada setor dessa distribuição citada acima. 0 levantamento foi realizado de acordo com os elementos estruturais: lajes, vigas e pilares, a fim de calcular o volume de concreto, área de forma e a quantidade de aço com o auxílio da ferramenta Excel. Através da ferramenta foi desenvolvido planilhas alimentadas com as dimensões e alturas dos elementos estruturais resultando nas áreas e volume de concreto (Figura 3).

Figura 3: Planilha para levantamento de quantitativo de acordo com o elemento estrutural

\begin{tabular}{|c|c|c|c|c|c|c|}
\hline \multicolumn{6}{|c|}{ PR24 - LAJE DO TÉRREO ÁREA DA PISCINA } & \\
\hline LAJE & $N^{\circ}$ LAJES & PERIMETRO (m) & ÁREA $\left(\mathrm{m}^{2}\right)$ & $\operatorname{ALTURA}(\mathrm{m})$ & Volume $\left(\mathrm{m}^{3}\right)$ & \\
\hline \multicolumn{6}{|c|}{$\begin{aligned} \mathrm{L} 1= & \mathrm{L} 10=\mathrm{L} 17=\mathrm{L} 18=\mathrm{L} 19 \\
& =\mathrm{L} 20=\mathrm{L} 21=\mathrm{L} 22\end{aligned}$} & \\
\hline \multicolumn{6}{|c|}{$\begin{array}{c}\mathrm{L} 2=\mathrm{L} 3=\mathrm{L} 5=\mathrm{L} \mathrm{L} 6=\mathrm{L} 9=\mathrm{L} 11 \\
=\mathrm{L} 14=\mathrm{L} 15=\mathrm{L} 16 \text { e sem } \\
\text { numeração }\end{array}$} & \\
\hline \multicolumn{6}{|l|}{$\mathrm{L} 7=\mathrm{L} 8=\mathrm{L} 12=\mathrm{L} 13$} & \\
\hline \multirow{2}{*}{\multicolumn{6}{|c|}{ PR16- LAJE DO TÉRREO }} & \\
\hline & & & & & & \\
\hline LAJE & $\mathrm{N}^{0}$ LAJES & PERIMETRO (m) & ÁREA $\left(\mathrm{m}^{2}\right)$ & ALTURA (m) & Volume $\left(m^{3}\right)$ & \\
\hline \multirow{2}{*}{\multicolumn{7}{|c|}{$\begin{array}{c}\text { L1-L17 e } 1 \text { sem } \\
\text { numeração }\end{array}$}} \\
\hline & & & & & & \\
\hline \multirow{2}{*}{ ELEMENTO } & \multicolumn{2}{|c|}{ TERREO } & \multicolumn{2}{|c|}{ ÁREA DA PISCINA } & \multicolumn{2}{|c|}{ TOTAL } \\
\hline & Área $\left(\mathrm{m}^{2}\right)$ & Volume $\left(\mathrm{m}^{3}\right)$ & Área $\left(\mathrm{m}^{2}\right)$ & Volume $\left(\mathrm{m}^{3}\right)$ & Área $\left(\mathrm{m}^{2}\right)$ & Volume $\left(\mathrm{m}^{3}\right)$ \\
\hline \multicolumn{7}{|l|}{ Laje } \\
\hline \multicolumn{7}{|l|}{ Viga } \\
\hline PROJETO & & 4e PR18 & PR16 & PR25 & & \\
\hline
\end{tabular}

Fonte: autor (2019).

O projeto arquitetônico em questão possui dois tipos de projetos estruturais: convencional e protendido. Para o concreto convencional, as áreas obtidas a partir dos projetos de forma foram utilizadas para obter 0 volume do concreto para estrutura convencional. 0 volume de concreto calculado foi de $1.553,76 \mathrm{~m}^{3}$ e a área construída do empreendimento, de $3035 \mathrm{~m}^{2}$.

O volume de concreto foi multiplicado por taxas comerciais dispostas no projeto estrutural e então, obtido o quantitativo de aço. 0 quantitativo de forma independe do volume de concreto, pois ele é obtido a partir da área construída e multiplicado por sua respectiva taxa comercial.

As taxas para o aço variam de acordo com o elemento estrutural, já para obtenção da área da forma é aplicado uma taxa geral (Tabela 1).

Tabela 1 - Taxa de consumo para estrutura em concreto armado convencional

\begin{tabular}{c|c|c}
\hline \multicolumn{1}{c|}{ ITEM } & ELEMENTO & TAXA \\
& Laje & $45,00 \mathrm{~kg} \cdot \mathrm{m}-3$ \\
\cline { 2 - 3 } Aço & Viga & $73,00 \mathrm{~kg} \cdot \mathrm{m}-3$ \\
\cline { 2 - 3 } & Pilar & $109,00 \mathrm{~kg} \cdot \mathrm{m}-3$ \\
\hline \multirow{2}{*}{ Forma } & Geral & $1,50 \mathrm{~m}^{2} \cdot \mathrm{m}-2$ \\
\hline
\end{tabular}

Fonte: ALMEIDA, Maria Andreza Santana (2019).

O projeto estrutural em concreto protendido as informações foram adquiridas através do programa Adapt. O Adapt é um software amplo e mais utilizado em projeto de lajes e vigas protendidas em todo o mundo, em sua análise é utilizado o método do pórtico equivalente, seu dimensionamento é de fácil acompanhamento para o usuário. 
O software forneceu o volume de concreto de $455,25 \mathrm{~m}^{3}$ e com o auxílio das taxas foi obtido o quantitativo de aço. 0 quantitativo de forma e cordoalha também foi calculado por meio de taxas, porém, assim como o convencional, foi utilizada a área construída do empreendimento (Tabela 2).

Tabela 2 - Taxa de consumo para estrutura em concreto protendido

\begin{tabular}{|c|c|c|}
\hline ITEM & ELEMENTO & TAXA \\
\hline \multirow{3}{*}{ Aço } & Laje & 37,00 kg.m-3 \\
\hline & Viga & 63,00 kg.m-3 \\
\hline & Pilar & 120,00 kg.m-3 \\
\hline Forma & Geral & $1,20 \mathrm{~m}^{2} \cdot \mathrm{m}-2$ \\
\hline Cordoalha & Geral & 29,00 kg.m-3 \\
\hline
\end{tabular}

O Adapt é muito bem aceito pelos profissionais de engenharia devido a execução de seus projetos de protensão com lucratividade e dentro dos prazos determinados, tudo isso é capaz por ser uma ferramenta que possui uma excepcional eficácia em fornecer de forma rápida os quantitativos e produzir projetos otimizados. É largamente utilizado como uma ferramenta de treinamento para engenheiros iniciantes nesse tipo de projeto estrutural.

A análise de viabilidade entre projetos foi realizada a partir da obtenção dos dados e quantitativos. Esse estudo de viabilidade é iniciado com a obtenção dos quantitativos de material, comparando consumo do volume de concreto, área da forma e peso de aço e cordoalha (Figura 4). Posteriormente o quantitativo foi inserido no ORSE e então adquirido o custo de cada material para análise comparativa.

Figura 4: Fluxograma do estudo de viabilidade para projeto em concreto armado convencional e concreto protendido

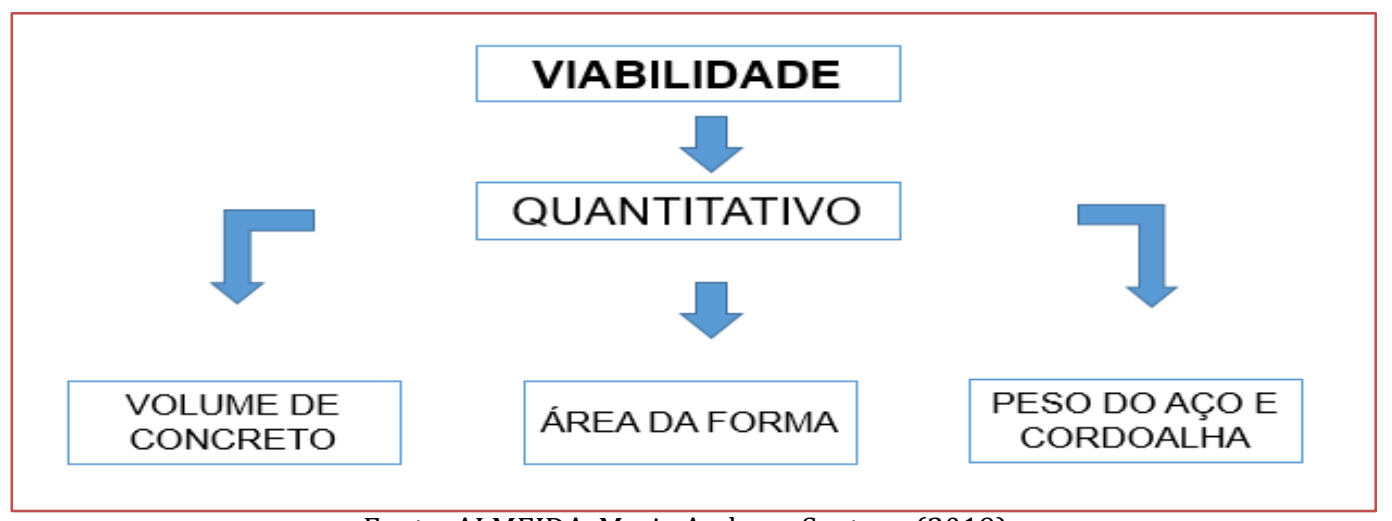

Fonte: ALMEIDA, Maria Andreza Santana (2019).

O sistema informatizado ORSE (orçamento de obras em Sergipe) tem o propósito de elaborar orçamentos de obras, sendo um software utilizado no Estado de Sergipe. Após a verificação do software foi verificado o custo de ambos os projetos e então estabelecido a viabilidade técnica e econômica dos projetos estruturais analisados.

A análise tem por finalidade verificar uma relação custo-benefício entre os tipos de projetos, avaliando ao final o projeto que possui menor impacto econômico no orçamento da obra, mas não minorando os critérios arquitetônicos e impacto ao conforto do usuário.

A viabilidade técnica e econômica analisada nesse trabalho não levará em consideração o serviço de mão de obra. Trata-se também de um estudo qualitativo, pois será apresentado as vantagens e características 
do sistema protendido, e um estudo quantitativo entre os dois sistemas estruturais: protendido e convencional, onde será apresentado a quantidade de materiais e os custos para cada método e em seguida discutido em uma comparação técnica avaliando a redução dos mesmos.

\section{RESULTADOS E DISCUSSÃO}

A estrutura de concreto armado convencional e concreto protendido apresentaram, de acordo com as análises realizadas, resultados distintos em cada etapa para conclusão do serviço de estrutura, onde a diferença de volume de concreto e aço mostraram-se significativas em comparação com o quantitativo de forma.

Na execução da estrutura durante a construção, a sequência a ser tomada, de modo geral, é a confecção das formas dos elementos estruturais, seguida da etapa de armação e por fim, concretagem. De acordo com os resultados, pode-se verificar que a redução de forma no protendido é de aproximadamente $20 \%$ do projeto convencional (Figura 5).

Figura 5: Comparativo da área de forma de estrutura em concreto armado convencional e em concreto protendido $\left(\mathrm{m}^{2}\right)$

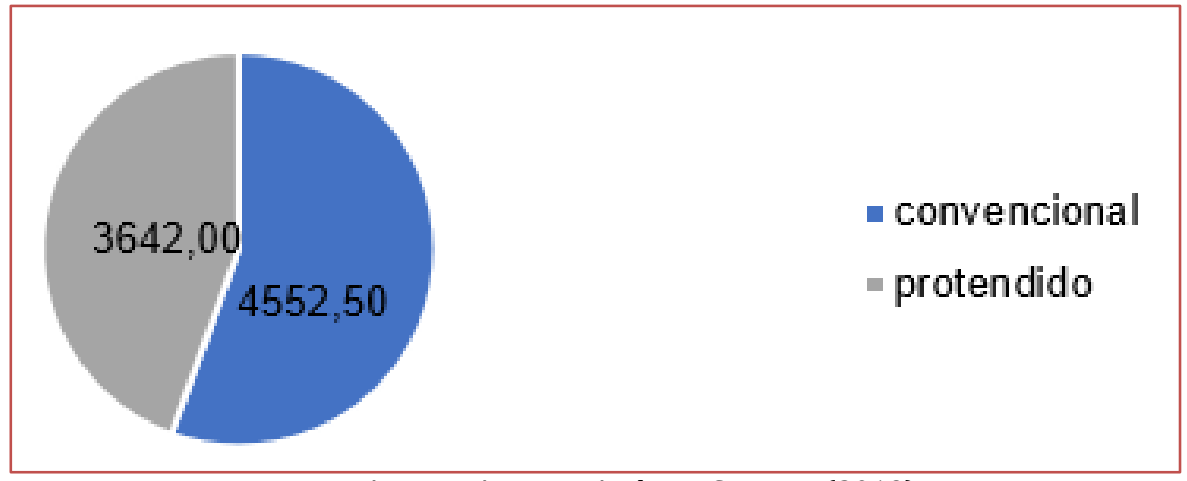

Fonte: ALMEIDA, Maria Andreza Santana (2019).

Como observado, o quantitativo de forma utilizado por ambos os métodos é similar, tornando a etapa de execução de forma um item não decisivo no processo de escolha. 0 valor aproximado pode ser justificado, pois a área de laje é a mesma em ambos os processos, ou seja, não há redução de área de laje no projeto de protensão, as mudanças estão relacionadas a redução de vigas e pilares.

O número de pilares e vigas no concreto convencional é maior, porém no levantamento de forma sua área é ínfima em comparação com a área de laje. A afirmativa outrora mencionada pode ser confirmada a partir de Tavares (2015) onde relata a possibilidade do concreto protendido vencer grandes vãos quando comparado a uma mesma seção em concreto convencional armado. Isso significa um menor número de pilares, o autor também afirma a redução nas espessuras das lajes acarretando numa significativa diminuição na altura total do prédio.

Quando comparado o volume de concreto, a diferença torna-se notória. A (Figura 6) ilustra o quantitativo de concreto utilizado para protendido e armado, onde o volume utilizado na estrutura protendida é aproximadamente $1 / 3$ da convencional, corroborando o fato de que a estrutura protendida reduz elementos estruturais e consequentemente o quantitativo de material. 
Figura 6: Comparativo do volume de concreto de estrutura em concreto armado convencional e em concreto protendido $\left(\mathrm{m}^{3}\right)$

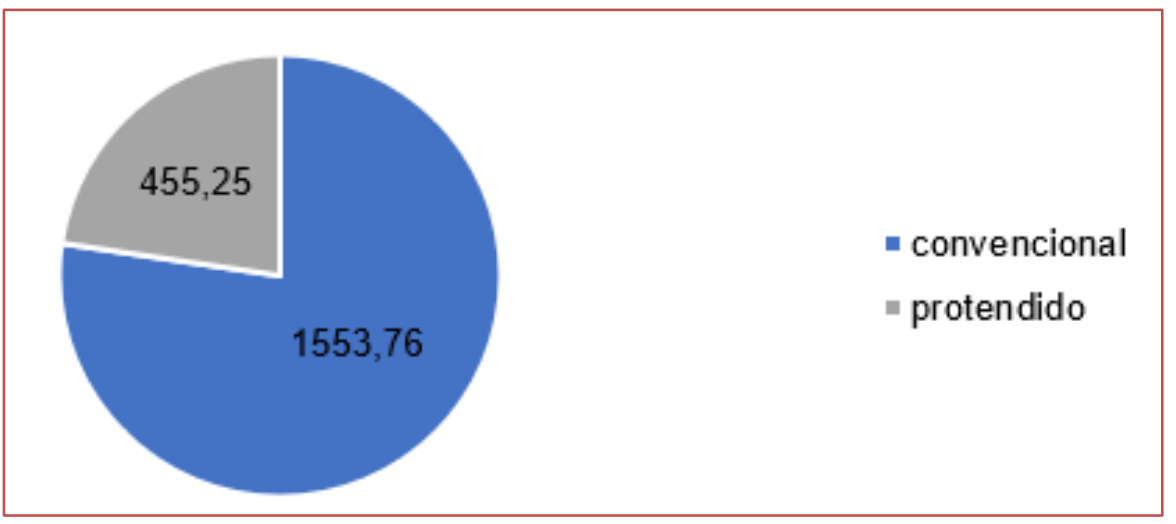

Fonte: ALMEIDA, Maria Andreza Santana (2019).

De acordo com os elementos estruturais, a redução do volume de concreto da (Figura 6) pode ser explicada através do decréscimo de pilares e vigas na estrutura protendida, a qual, respeita os critérios de segurança exigidos para suportar as cargas solicitadas pela edificação. A laje, por sua vez, não apresenta redução, pois representa a área construída da edificação, independentemente do tipo de estrutura, entretanto na estrutura convencional o volume de concreto ainda é maior devido sua maior espessura.

Tateoka (2012) aponta em entrevistas com especialistas que a vantagem da estrutura protendida é o ganho do pé direito devido sua baixa espessura, proporcionando a execução de mais um ou dois pavimentos. Desse modo, a redução do volume de concreto está ligada a redução da espessura das lajes, bem como redução dos pilares e vigas na estrutura.

0 quantitativo de aço apresenta redução similar ao concreto em ambos os métodos executivos. 0 consumo de aço na estrutura convencional corresponde a mais de $70 \%$ em relação a estrutura protendida, atrelado ao aumento de vigas e pilares. Entretanto, o diâmetro das barras de aço pode colaborar também para redução, pois o quantitativo informado corresponde ao peso total, independente de diâmetro (Figura 7).

Figura 7: Comparativo do quantitativo de aço de estrutura em concreto armado convencional e em concreto protendido $(\mathrm{kg})$

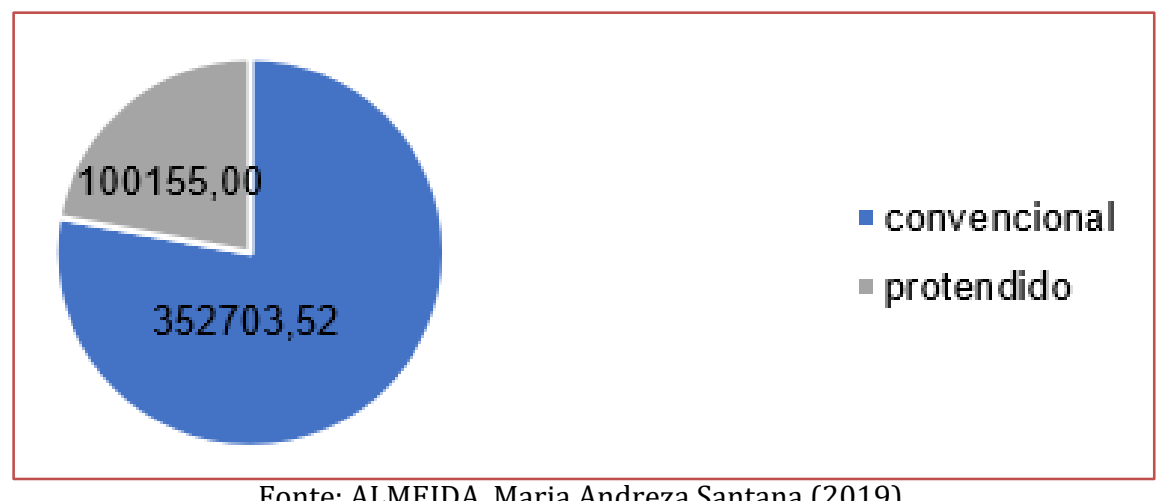

Fonte: ALMEIDA, Maria Andreza Santana (2019).

Nas lajes foram utilizadas barras de 6,3 e 8,0 mm, enquanto nos pilares e vigas barras de até 20,00 mm, no concreto convencional. Barras com maior diâmetro implicam em maior peso, consequentemente o peso de armadura no concreto convencional eleva, visto que o número de pilares e vigas é fator crucial na determinação do consumo de aço e que estrutura em concreto protendido tem uma significativa redução desses elementos.

Giovanaz e Fransozi (2017) comentam que na protensão o aço utilizado refere-se a aproximadamente 1/3 do que seria utilizado no concreto armado, porém ele deve ser de alta resistência. Tavares (2015) mostra que a redução na espessura das lajes influi também para uma economia na fundação, visto que a redução 
das espessuras nas lajes contribuirá para uma significativa diminuição no gabarito do prédio e, consequentemente um menor peso total da estrutura.

A cordoalha não está presente no concreto convencional, sendo item principal para diferenciação dos métodos. 0 seu consumo no concreto protendido foi de $13.202,25 \mathrm{~kg}$, porém seu impacto está relacionado ao custo final da execução da etapa estrutural.

De fato, de acordo com a Pini (2005), a cordoalha aderente ou não aderente, onde a primeira, em teoria, é mais adequada para edifícios convencionais por maior capacidade de tensionamento, possuem custo maior que a armadura passiva convencional, o que, em primeiro momento pode levar a não utilização do sistema de protensão por acreditar que o preço é elevado.

$\mathrm{Na}$ análise dos projetos, pode-se verificar que o custo da cordoalha no orçamento global da estrutura foi pequeno em comparação com os demais itens, representando aproximadamente $9 \%$ do orçamento (Figura 8).

Figura 8: Orçamento global para estrutura em concreto armado convencional e em concreto protendido

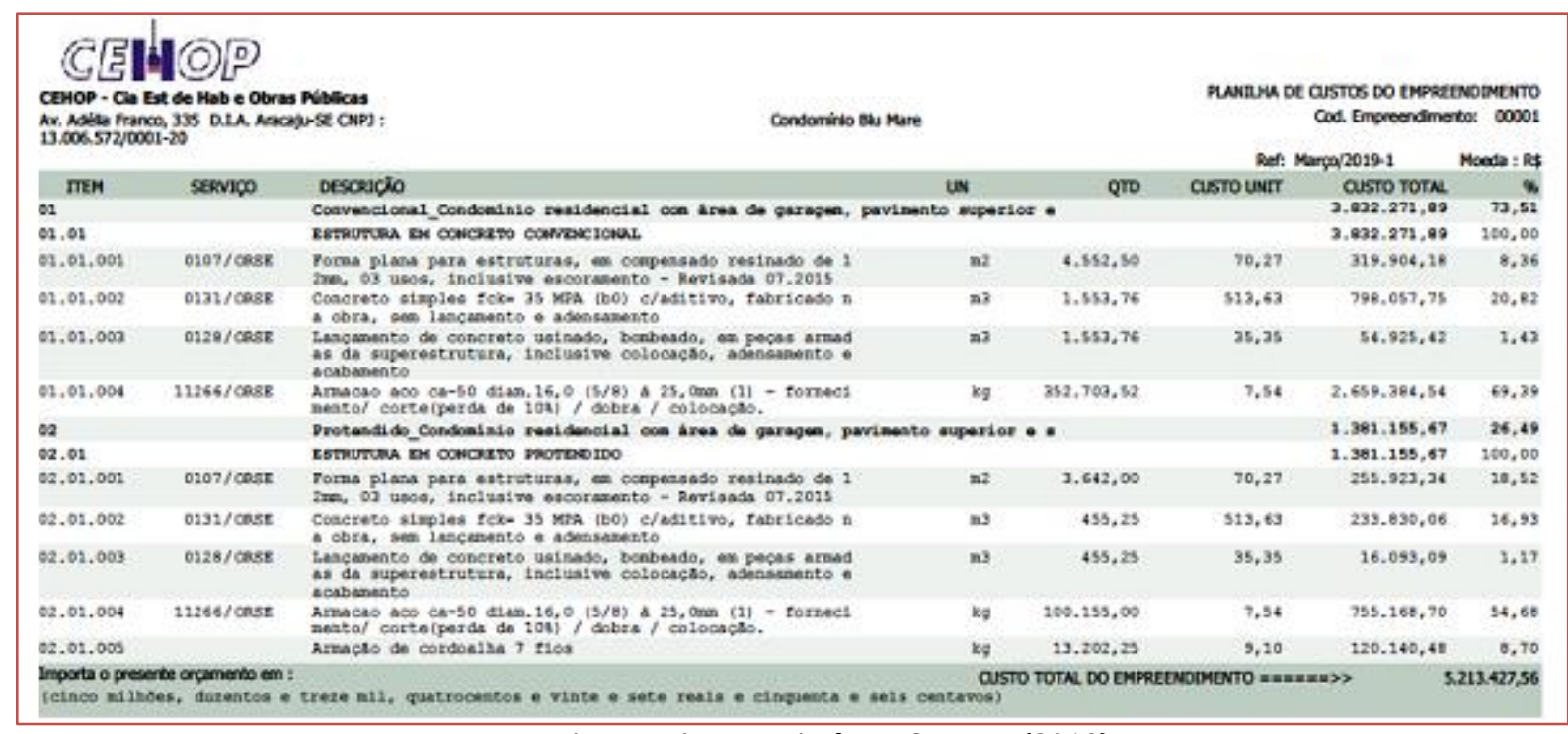

Fonte: ALMEIDA, Maria Andreza Santana (2019).

O percentual diminuto está atrelado ao quantitativo de cordoalha utilizado para execução. Os cabos estão presentes nas lajes e foi utilizado $13.202,25 \mathrm{~kg}$ de cordoalhas com 7 fios, onde o custo da cordoalha foi obtido através do preço comercial no valor de $\mathrm{R} \$ 9,10 / \mathrm{kg}$ para o Estado de Sergipe.

O custo do aço e do concreto são equivalentes e reduziram mais de $70 \%$ do custo do concreto convencional. $\mathrm{O}$ aço confere a estrutura protendida significativa economia, visto que corresponde a $60 \%$ do custo global para o concreto protendido e $70 \%$ do valor do concreto convencional (Figura 9).

Figura 9: Comparativo de custo do aço de estrutura em concreto armado convencional e em concreto protendido

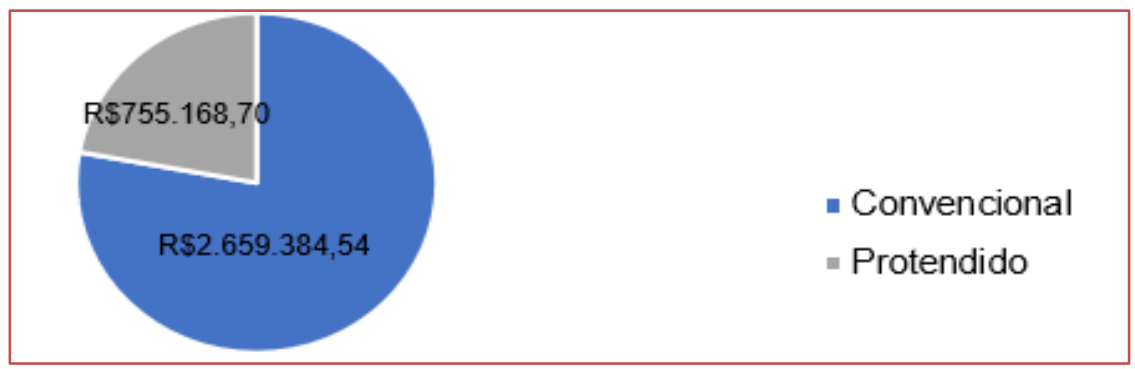

Fonte: ALMEIDA, Maria Andreza Santana (2019). 
O concreto, por sua vez, representa cerca de $22 \%$ do custo do concreto convencional e aproximadamente $20 \%$ do concreto protendido. A redução do valor está relacionada ao decréscimo do volume utilizado para o concreto protendido, tornando uma estrutura, em termos materiais, mais barata que a estrutura convencional (Figura 10).

Figura 10: Comparativo de custo de concreto de estrutura em concreto armado convencional e em concreto protendido

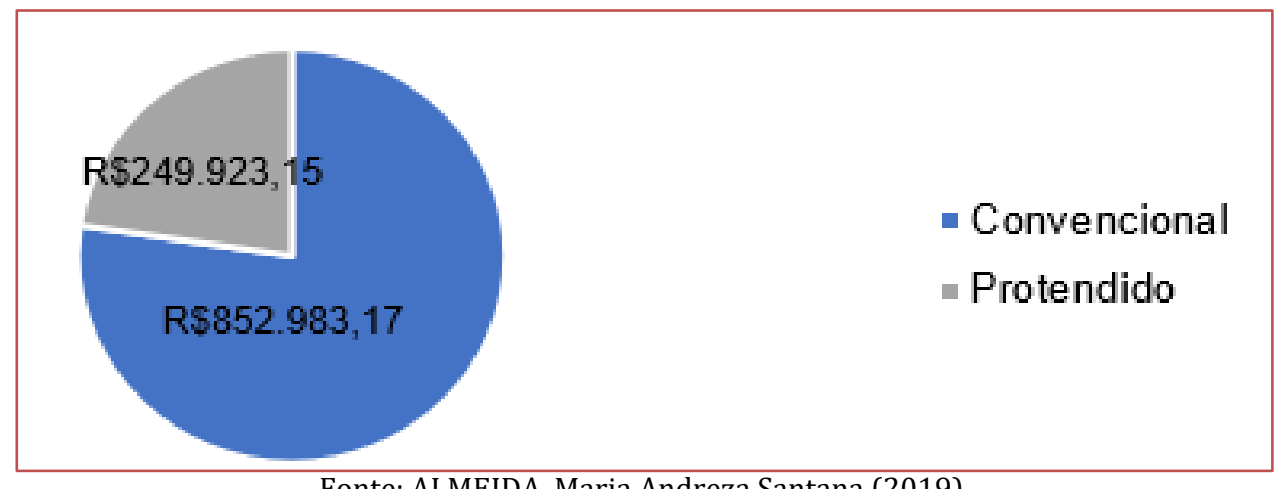

Fonte: ALMEIDA, Maria Andreza Santana (2019).

0 custo da forma representa menos de $10 \%$ do custo do concreto convencional e $20 \%$ do concreto protendido, apesar do percentual distinto em termos de impacto no orçamento, o custo de ambos os métodos para a forma foi similar, o que acarretou em $20 \%$ de economia no quesito forma, como observado na (Figura 11).

Figura 11: Comparativo de área de forma de estrutura em concreto armado convencional e em concreto protendido

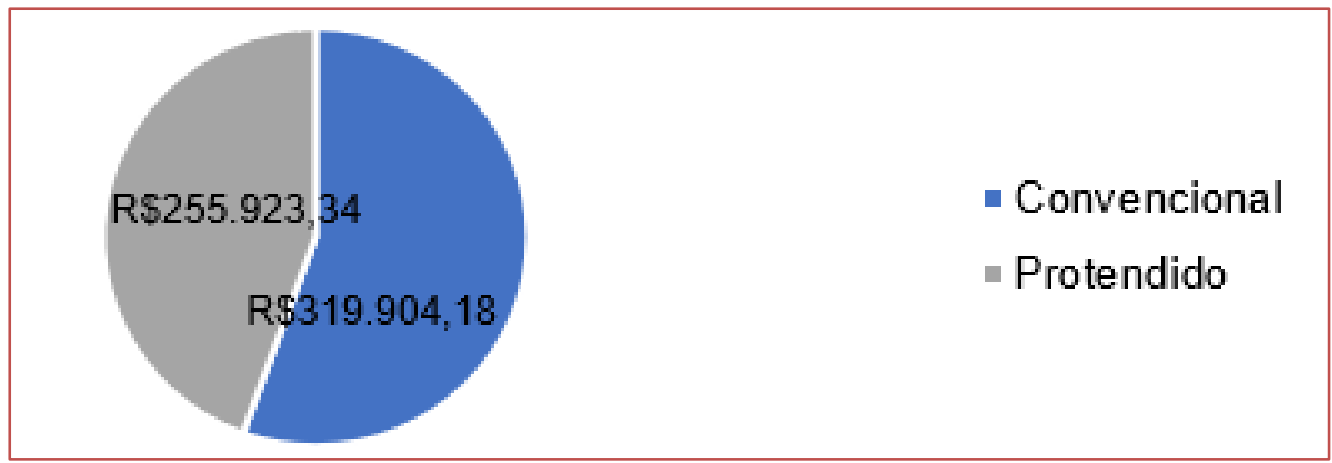

Fonte: ALMEIDA, Maria Andreza Santana (2019).

O orçamento revelou que o concreto protendido tem custo significativo menor que o concreto convencional, revelando economia de aproximadamente $70 \%$ do custo da estrutura na obra. 0 custo da obra em concreto protendido foi de $\mathrm{R} \$ 1.381 .155,67$ e do concreto convencional $\mathrm{R} \$ 3.832 .271,89$, onde os itens de maior relevância foram o aço e o concreto.

Schmid M. (2009) afirma que sistema estrutural protendido quando comparado ao sistema convencional apresenta viabilidade econômica. 0 autor relaciona a economia fundamentalmente ao parâmetro vão tendo em vista que, vencer grandes vãos é uma das principais características do sistema. Por esse fator, o sistema torna-se melhor viável quando o método é aplicado em obras que apresentam grandes vãos.

Correlacionando custo e qualitativo levantado, pode-se obter o consumo aproximado para cada método. A (Tabela 3) mostra o consumo de material para a estrutura protendida. 
Tabela 3 - Consumo de material em estrutura em concreto protendido

\begin{tabular}{c|c|c|c}
\multicolumn{1}{c|}{ ITEM } & CONSUMO & CUSTO UNITÁRIO & TOTAL \\
Forma & $1,20 \mathrm{~m}^{2} \cdot \mathrm{m}^{2}$ & $70,27 \mathrm{R} \$ / \mathrm{m}^{2}$ & $\mathrm{R} \$ / \mathrm{m}^{2} 84,32$ \\
\hline Concreto & $0,15 \mathrm{~m}^{3} \cdot \mathrm{m}^{2}$ & $548,98 \mathrm{R} \$ / \mathrm{m}^{3}$ & $\mathrm{R} \$ / \mathrm{m}^{2} 82,35$ \\
\hline Aço & $33,00 \mathrm{~kg} \cdot \mathrm{m}^{2}$ & $7,54 \mathrm{R} \$ / \mathrm{kg}$ & $\mathrm{R} \$ / \mathrm{m}^{2} 248,82$ \\
\hline Cordoalha & $4,35 \mathrm{~kg} \cdot \mathrm{m}^{2}$ & $9,10 \mathrm{R} \$ / \mathrm{kg}$ & $\mathrm{R} \$ / \mathrm{m}^{2} 39,59$ \\
\hline \multicolumn{3}{c}{ TOTAL } & $\mathrm{R} \$ / \mathrm{m}^{2} 455,11$ \\
\hline
\end{tabular}

Fonte: ALMEIDA, Maria Andreza Santana (2019).

A (Tabela 4) ilustra o consumo de material para a estrutura convencional. Note que, o valor por metro quadrado é discrepante da convencional para a protendida. 0 valor de uma estrutura protendida custaria em média $\mathrm{R} \$ 455,11 / \mathrm{m}^{2}$, enquanto a convencional $\mathrm{R} \$ 1.261,61 / \mathrm{m}^{2}$.

Tabela 4 - Consumo de material em estrutura em concreto armado convencional

\begin{tabular}{|c|c|c|c|}
\hline ITEM & CONSUMO & CUSTO UNITÁRIO & TOTAL \\
\hline Forma & $1,50 \mathrm{~m}^{2} \cdot \mathrm{m}^{-2}$ & $70,27 \mathrm{R} \$ / \mathrm{m}^{2}$ & $\mathrm{R} \$ / \mathrm{m}^{2} 105,41$ \\
\hline Concreto & $0,51 \mathrm{~m}^{3} \cdot \mathrm{m}^{-2}$ & $548,98 \mathrm{R} \$ / \mathrm{m}^{3}$ & $\mathrm{R} \$ / \mathrm{m}^{2} 279,98$ \\
\hline Aço & 116,21 kg.m- ${ }^{2}$ & $7,54 \mathrm{R} \$ / \mathrm{kg}$ & $\mathrm{R} \$ / \mathrm{m}^{2} 876,22$ \\
\hline \multicolumn{3}{|c|}{ TOTAL } & $\mathrm{R} \$ / \mathrm{m}^{2} 1.261,61$ \\
\hline
\end{tabular}

Fonte: ALMEIDA, Maria Andreza Santana (2019).

A redução de $70 \%$ aproximadamente no valor do metro quadrado infere que a estrutura em concreto protendido é mais econômica que a de concreto convencional. Entretanto, a execução em concreto convencional ainda é recorrente, de acordo Pinheiro (2007) essa técnica apresenta maior recorrência de utilização devido ao baixo custo de mão de obra, já que é um processo que não exige profissionais com elevado nível de qualificação, além de ser um processo conhecido e bem difundido em todo o país.

A redução do custo, é de suma importância mencionar, está diretamente ligada ao quantitativo de material, desse modo, comparado os dois sistemas, a relação custo concreto convencional-concreto protendido é de 2,80, ou seja, a despesa com material para o concreto armado convencional custa aproximadamente três vezes mais que o concreto protendido. Um dos fatores que leva a não utilização do sistema de protensão é a acomodação no sistema convencional e os estigmas levantados sobre o sistema.

De acordo com a Pini (2005), o projeto estrutural protendido é mais complexo e o custo do aço para protensão é maior que o da armadura passiva, contudo outros aspectos devem ser levados em conta para adoção da técnica, como o desempenho da edificação, redução das deformações, comportamento em relação a fissuras e a resistência ao puncionamento.

Albuquerque (1999 apud SILVA, 2002) complementa atrelando ao custo global da obra. 0 autor (1999 apud SILVA, 2002) aponta que a etapa da execução da estrutura corresponde a 15-20\% do custo total da obra; um estudo antecipado para escolha do sistema pode impactar numa redução desse custo global, ou seja, se reduzir $10 \%$ no custo da estrutura, o impacto no custo global seria de $2 \%$ de redução.

0 percentual é ínfimo, então adotar um sistema 5\% mais caro ou barato não influencia significativamente no custo global da obra, a mudança reflete em outras etapas construtivas como menos alvenaria, pilares mais distantes, menos lajes de transição e garagens livres de pilares (TATEOKA, 2012).

Sendo a protensão um serviço pouco comum, e exige cuidados e mão-de-obra especializada, uma opção para difusão da técnica é a utilização do serviço terceirizado. A terceirização é trivial entre as construtoras, ficando responsáveis pela disponibilização, além do serviço, de equipamentos e materiais como macacos, bombas, injeção, máquina para corte de aço, fitas de vedação, massa de vidro, aditivos e purgadores, além do fornecimento de ancoragens, bainhas e acompanhamento técnico especializado (PINI, 2005). 
Os especialistas entrevistados por Tateoka (2012) apontam ainda que com a transição convencional para sistema protendido a economia de tempo pode chegar a 100 dias e quando concebido desde o princípio agiliza-se fundação, estrutura, garagem e pessoal. Ainda de acordo com a jornalista (2012) quem utiliza o sistema de protensão não retoma para o convencional devido ao ganho de produtividade.

\section{CONSIDERAÇõES FINAIS}

A utilização do sistema de protensão em edificações verticais ainda é pouco difundido em detrimento ao concreto convencional. O mercado da construção criou resistência na adoção do método e firmou preconceitos atrelando seu uso ao custo elevado, eximindo da soma as vantagens que o sistema de concreto protendido pode conferir a estrutura e a construção de um modo geral.

O concreto protendido, conforme os dados da literatura, convergem para aumento de vão, resultando em pavimento com maior liberdade de pilares e vigas, garante conforto e desempenho arquitetônico, ganho de gabarito de altura na edificação vertical e redução do tempo de execução da obra. Esse ganho de produtividade está atrelado também a economia.

Os resultados do presente trabalho apontaram que o sistema protendido é aproximadamente $1 / 3$ do concreto armado convencional. A redução de materiais está relacionada de forma mais significativa no quantitativo de aço e no volume de concreto. A forma em ambos os métodos apresentou similaridade em valores e quantidade, já as cordoalhas no protendido não mostram percentual relevante no custo global da estrutura, servindo como desmistificação do custo desse material no projeto.

Sendo assim, o concreto protendido apresenta economia de material, bem como economia no custo destes. A elevação dos preços está atrelada a mão de obra ou terceirização do serviço, contudo esse custo pode ser equilibrado com a economia da sequência construtiva. 0 projeto em concreto protendido otimiza o processo, reduz o tempo de execução e a economia reflete na produtividade elevada com redução do tempo da obra e consequentemente da mão-de-obra, bem como economia nos itens como alvenaria e afins.

Como sugestão para trabalhos futuros, pode-se através da mesma analogia, e com o emprego de softwares de projeto estrutural, como Eberick e Adapt, fazer o comparativo global dos quantitativos de materiais e custos, adicionando minuciosamente a questão da mão-de-obra ou terceirização e correlação com a produtividade, analisando-se também a influência nos elementos de fundações e desempenho arquitetônico.

\section{REFERÊNCIAS}

[1] ASSOCIAÇÃO BRASILEIRA DE NORMAS TÉCNICAS. NBR 6118: projetos de estrutura de concreto. Procedimentos - Apresentação. Rio de Janeiro: 2014.

[2] BASTOS, P. S. S. Fundamentos do concreto armado: notas de aula. Bauru-SP: Universidade Estadual Paulista, 2006.

[3] CASTRO, S. V. Concreto protendido: vantagens e desvantagens dos diferentes processos de protensão do concreto nas estruturas. Belo Horizonte: 2011.

[4] GIOVANAZ, A. H. e FRANSOZI, C. B. P. Estruturas de concreto protendido. Revista Destaques Acadêmicos, 2017.

[5] PINHEIRO, L. M. Fundamentos do Concreto e Projeto de Edifícios. São Carlos/SP: Universidade de São Paulo, 2007.

[6] PINI W. Concretos e cabos. Notícias Pini web. Jan. 2005. Disponível em:<http://piniweb17.pini.com.br/construcao/noticias/concretos-e-cabos-79438-1.aspx>. Acesso em: 12 de maio 2019.

[7] SCHMID, M. T. Lajes planas protendidas. 3 ed. Rudloff Industrial Ltda, 2009.

[8] SCHMID, Maria R. L. Porque protender uma estrutura de concreto? Revista Concreto, 2007. Disponível em <http://wwwp.feb.unesp.br/pbastos/Protendido/Por\%20que\%20Protender.pdf> acessado em 10/05/2019.

[9] SILVA, Andréia Rodrigues da. Análise comparativa de custos de sistemas estruturais para pavimentos de concreto armado. Dissertação apresentada ao Programa de Pós-Graduação em Engenharia de Estruturas da Escola de Engenharia da Universidade Federal de Minas Gerais. Belo Horizonte: 2002. 
[10] SOUZA, J. P. V. L e MACEDO, M, G, G. Lajes lisas em concreto protendido análise e dimensionamento estrutural. Goiânia: 2016.

[11] TATEOKA, Thays. Vãos protendidos. Revista Construção Mercado. São Paulo: ed. 126, Jan. 2012. Disponível em: <http://construcaomercado17.pini.com.br/negocios-incorporacao-construcao/126/vaos-protendidos-escassezde-empresas-que-investem-em-estudo-283965-1.aspx>. Acesso em: 12 de maio 2019.

[12] TAVARES, P. A economia gerada no sistema protensão em relação ao sistema convencional. Revista Momento Engenharia, 2015. Disponível em <https://momentoengenharia.wordpress.com/2015/09/24/a-economia-gerada-nosistema-protensao-em-relacao-ao-sistema-convencional/> acessado em 10/05/2019. 


\section{Capítulo 3}

\section{Avaliação dos aspectos e impactos socioambientais no complexo termoelétrico porto de Sergipe no município de Barra dos Coqueiros/SE}

\section{Dayane Santana Santos \\ Neuma Rúbia Figueiredo Santana \\ Iris Sterfanie Santos}

Resumo: A construção civil é um setor que contribui para o desenvolvimento econômico e social de um país, embora também seja responsável por degradar excessivamente o meio ambiente, interferindo nos meios biótico, físico e antrópico. 0 objetivo deste trabalho é diagnosticar os principais impactos e aspectos socioambientais ocorridos durante a implantação do Complexo Termoelétrico Porto de Sergipe, através de uma pesquisa qualitativa e quantitativa, analisando o Estudo de Impacto Ambiental (EIA) do empreendimento e o impacto dessas ações sobre a população. Além de estudo bibliográfico, foi aplicado questionário com a população residente nas proximidades da termoelétrica. Os resultados apontaram como principal benefício para a comunidade a melhora da economia local. Os principais impactos negativos relatados foram a emissão de poeira, alteração do trânsito local, redução de animais silvestres e redução de áreas de preservação permanente (APP).

Palavras-chave: Impactos socioambientais. Sustentabilidade. Construção civil. 


\section{INTRODUÇÃO}

As crescentes pressões feita pela sociedade e o aumento da consciência ambiental, surgiram como resultado dos impactos ecológicos, econômicos e sociais, resultantes da introdução de vários tipos de empreendimentos, e fundamentaram-se como fatores essenciais para o uso de práticas adequadas de gerenciamento ambiental (REIS, 2010).

Antunes (2001) relata que através do licenciamento a Administração Pública estabelece exigências e limites para o exercício de determinadas atividades. Completando, afirma que apenas serão permitidas práticas e condutas cujos impactos ambientais estejam dentro dos padrões estabelecidos, ou quando estes forem de pequena relevância. Medidas mitigadoras também devem ser sugeridas para os impactos negativos das atividades.

A Avaliação de Impacto Ambiental (AIA) e o Estudo de Impacto Ambiental (EIA) e seu Relatório de Impacto Ambiental (RIMA) destacam-se como os principais estudos ambientais do processo de licenciamento ambiental (FERREIRA,2010). Essa ferramenta foi inserida no Brasil em 1981, por meio da Lei no 6.938 de 1981 da Política Nacional do Meio Ambiente e a partir de 1986 passou a ser obrigatória para empreendimentos que causem degradação ambiental significativa ou em áreas suscetíveis a proteção, conservação e recuperação do meio ambiente de acordo com a Resolução CONAMA 001/86 (SANCHES, 2011).

Segundo a Resolução CONAMA no 01/86, no caso de grandes canteiros de obras é exigido estudos ambientais mais completos do EIA e do RIMA. A resolução também estabelece aos órgãos responsabilidade à realização de AIA e EIA/RIMA, bem como o fornecimento de sugestões para sua elaboração, além de listar as atividades e empreendimentos que, para serem licenciados, necessitam de uma Avaliação de Impactos.

0 processo de licenciamento ambiental exibe a necessidade de garantir ao máximo a preservação ambiental e expressa a preocupação em proteger os recursos naturais do país. Diante desse cenário, o presente trabalho objetiva identificar os impactos socioambientais decorrentes ao processo construtivo do Complexo Termoelétrico Porto de Sergipe, na perspectiva dos moradores das comunidades adjacentes por meio das entrevistas e dos aspectos observados durante as visitas "in loco", a fim de contrastar com os estudos ambientais do empreendimento.

\section{METODOLOGIA}

A metodologia de desenvolvimento de pesquisa do estudo de caso estruturou-se em 4 etapas:

Etapa 1 - Elaboração do questionário para a aplicação nas entrevistas, correlacionando aspectos ambientais e sociais.

Etapa 2 - Realização de entrevistas com a comunidade e registro fotográfico das proximidades do Complexo Termelétrico Porto do Sergipe (CTPS).

Etapa 3 - Elaboração da matriz de impactos e aspectos ambientais, utilizando a proposta de (DEGANI,2003).

Etapa 4 - Análise dos resultados demonstrados através de gráficos.

0 presente estudo caracterizou-se como um estudo de caso, que é definido por um estudo aprofundado e exaustivo de algo, com o objetivo de permitir o conhecimento amplo e detalhado do objeto em questão. Esta pesquisa pode incluir entrevista, aplicação de questionários, testes e observação participante ou não, de acordo com a necessidade do trabalho (GIL,2008).

0 presente estudo foi realizado no município da Barra dos Coqueiros, fundado em 25 de novembro de 1953. A cidade é localizada na Região Metropolitana de Aracaju, localizada a $5 \mathrm{~km}$ da capital sergipana (Figura 1). A cidade de Barra dos Coqueiros fica à margem esquerda do rio Sergipe, vizinha dos municípios de Aracaju, Santo Amaro das Brotas e Pirambu, ocupa uma área de $90,322 \mathrm{~km}^{2}$ a qual representa $0,41 \%$ do território sergipano, e no último censo contava com uma população de 25.012 habitantes (IBGE, 2010). 
Figura 1: Localização de Barra dos Coqueiros/SE
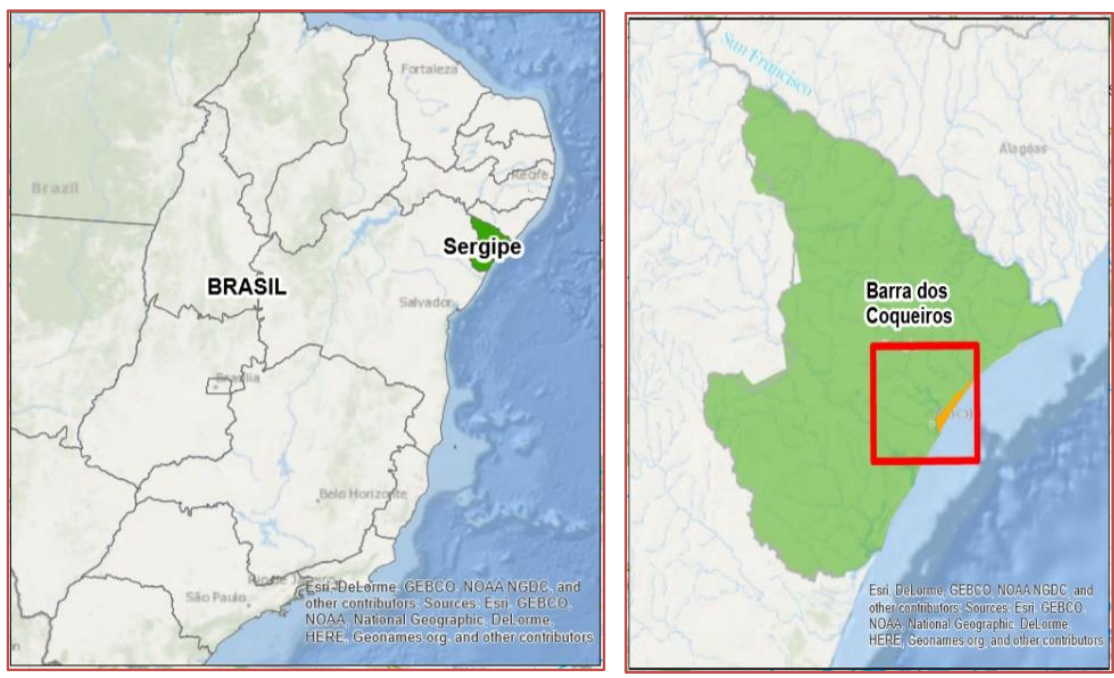

Fonte: Adaptado de (CELSE,2017)

O Complexo Termelétrico Porto do Sergipe (CTPS) é composto pelas Usinas Termelétricas (UTEs) Porto de Sergipe 1, Laranjeiras 1 e Governador Marcelo Déda com área total de $1.646 .886,31 \mathrm{~m}^{2}$, além das linhas de transmissão e instalações e operações Offshore (Figura 2). 0 empreendimento localiza-se na zona rural, nas proximidades do povoado Jatobá, numa área de baixo adensamento populacional, com a presença de atividades agrícolas, industriais e de serviços. Localizado a cerca de $14 \mathrm{~km}$ do centro da cidade de Barra dos Coqueiros e a cerca de $20 \mathrm{~km}$ de Aracaju.

Figura 2: Vista aérea do Complexo Termelétrico Porto de Sergipe

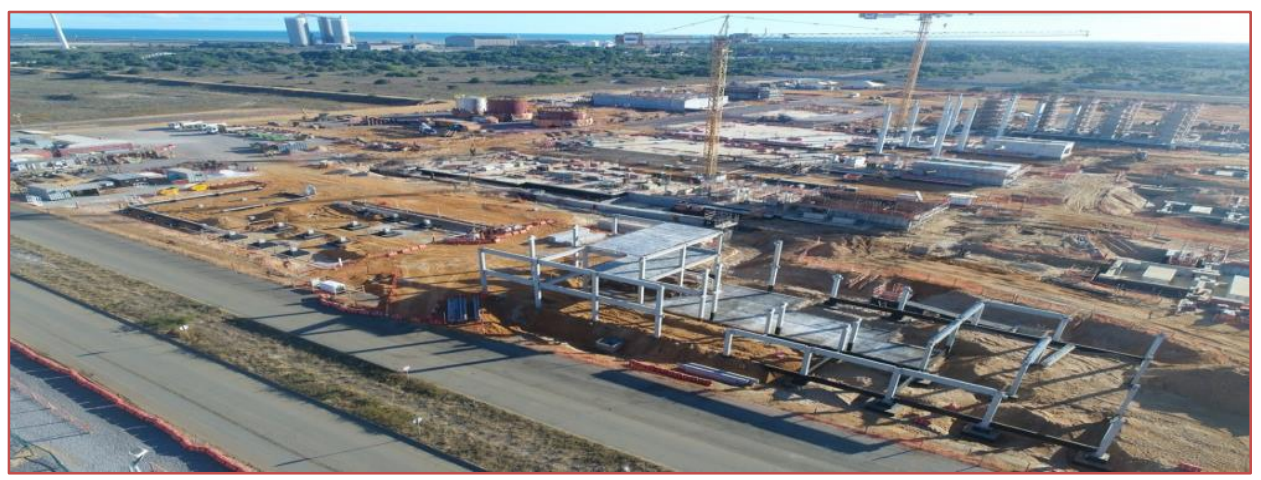

Fonte: www.infonet.com.br acessado em 12 de maio de 2018.

O CTPS será instalado em uma área onde antes seria um Polo Cloroquímico e por esta razão, já havia sido realizado no local a implantação de algumas estruturas básicas como a supressão de vegetação, vias de acesso, terraplenagem, drenagem pluvial dentre outros, desde o ano de 1969 (Figura 3). 
Figura 3: Localização do Complexo Termelétrico Porto de Sergipe

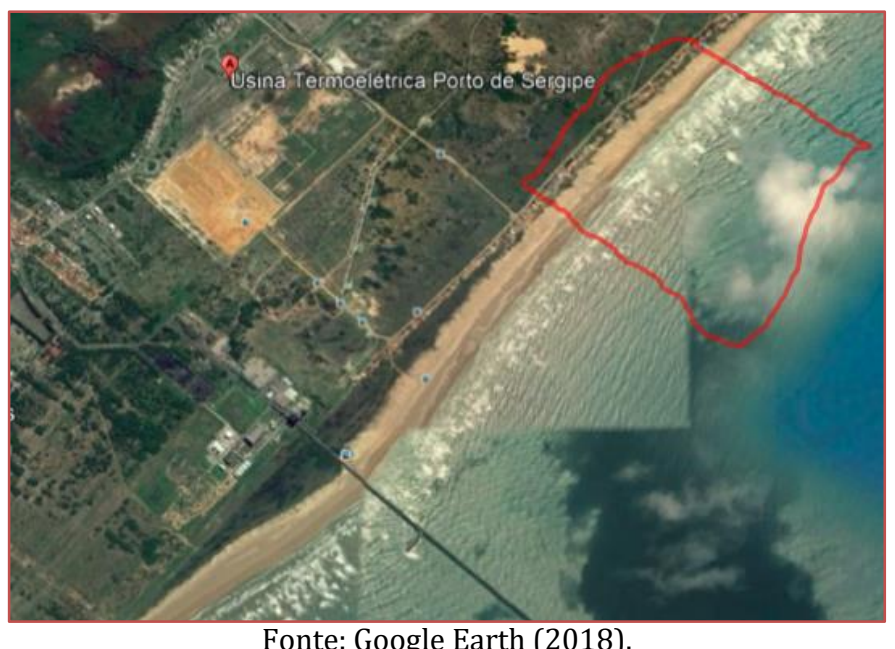

A área destinada a implantação das unidades termelétricas e suas áreas de influências direta e indireta, estão associadas a uma região do litoral sergipano, onde podem ser encontradas uma variedade de ecossistemas que pertencem ao Bioma Mata Atlântica: manguezal, restinga, dunas, praia e corpos d'água alagáveis. Ambos os ambientes apresentam fauna e flora diversificadas.

Para o estudo em questão foi realizada inicialmente pesquisa bibliográfica através de livros, dissertações, teses, artigos científicos, revistas acadêmicas, leis e normas referentes ao tema, encontrados em sites acadêmicos por meio eletrônico (Internet) e em acervo da Biblioteca da Faculdade Pio Décimo e da Universidade Federal de Sergipe.

Também foram analisados o Estudo Ambiental Complementar, Estudo de Impacto Ambiental (EIA), relatório socioambiental do Complexo Termoelétrico Porto de Sergipe elaborados pela CH2M Hill do Brasil Engenharia Ltda., Relatório de Impacto Ambiental (RIMA), Relatório Ambiental Simplificado (RAS) elaborado por Genival Nunes Consultoria de Projetos e Meio Ambiente LTDA - EPP

Além dos documentos supracitados participou das análises os processos referentes a implantação do Complexo Termoelétrico disponibilizados pela ADEMA - Administração Estadual do Meio Ambiente, material solicitado através de ofício emitido pela Faculdade Pio Décimo.

Após a pesquisa bibliográfica foi elaborado e aplicado um questionário socioambiental com 11 questões que abordam os seguintes temas: perfil do morador da região, relação entre a empresa e a comunidade, impactos socioambientais na percepção da comunidade e os benefícios da implantação do empreendimento no ponto de vista de cada entrevistado. As observações realizadas "in loco" ocorreram nos dias 05 e 06 de maio de 2018, nas proximidades do Complexo Termelétrico Porto de Sergipe. Após a segunda visita, 20 moradores concordaram em participar da pesquisa.

A análise dos dados incluiu uma abordagem qualitativa e quantitativa. Os resultados dos questionários realizados foram inseridos em planilhas do Microsoft Excel, em seguida realizou-se a composição dos gráficos, com a intuito de confrontar as informações descritas nos relatórios criados pela incorporadora do Complexo Termelétrico Porto de Sergipe.

\section{RESULTADOS E DISCUSSÃO}

\subsection{PERDAS DE ÁREAS DE PRESERVAÇÃO PERMANENTE}

A região em estudo encontra-se em uma planície costeira e apresenta vários ecossistemas pertencentes ao Bioma Mata Atlântica como restinga, manguezal, dunas, praia e corpos d'água alagáveis. Segundo a Lei $\mathrm{n}$ o 6.938/1981 da Política Nacional do Meio Ambiente (PNMA), deve-se assegurar e proteger os ecossistemas, com a preservação de áreas representativas para manter o equilíbrio ecológico. $\quad$ A área onde está sendo construído o CTPS está terraplanada com uma cobertura de argila na camada superior desde o ano de 1969. Segundo os relatórios ambientais essa cobertura foi o que impediu da vegetação se recompor, mas não causou impactos relevantes associados a flora e fauna. Em contrapartida observa-se 
que apesar da região ter sofrido bastante degradação, torna-se evidente a presença de restingas e de várias espécies de animais em toda região dentro e ao redor de todo complexo (Figura 4A e 4B).

Figura 4: A - Fauna local; B - Flora local.

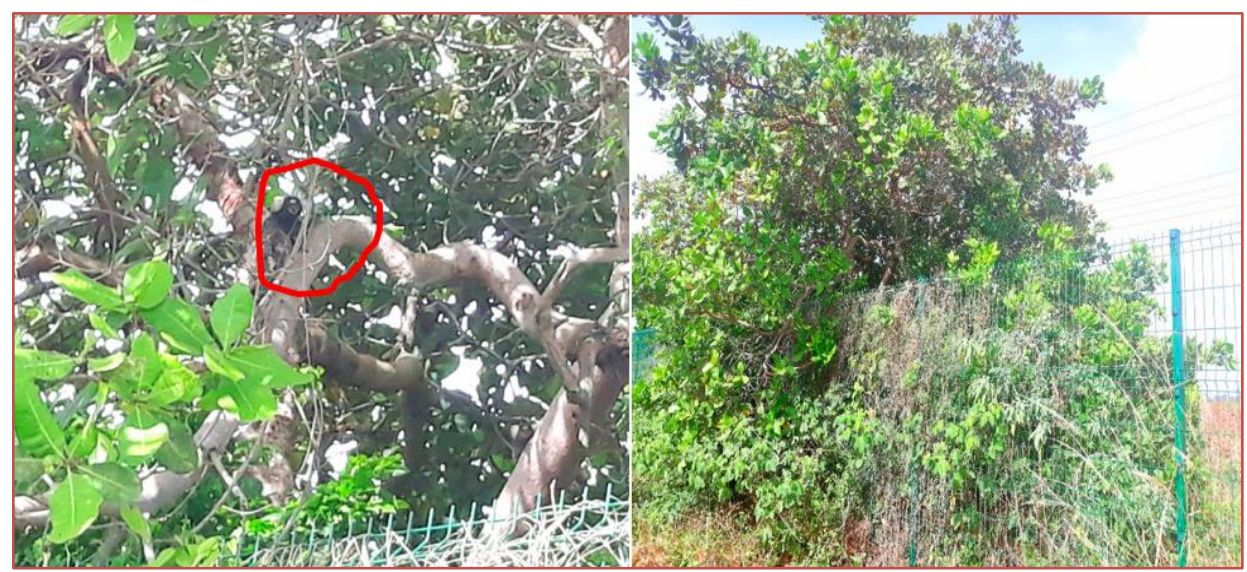

Fonte: Trabalho de campo, 2018.

Conforme definição da Lei nº. 12.651/2012 do Novo Código Florestal, área de preservação permanente é uma área protegida, coberta ou não por vegetação nativa, com a função ambiental de preservar os recursos hídricos, a paisagem, a fixidade geológica e a biodiversidade, além de auxiliar o fluxo gênico de fauna e flora, proteger o solo e garantir o bem-estar das populações humanas.

Ainda de acordo com a lei supracitada as restingas (Figura 5), quando classificadas como fixadoras de dunas ou estabilizadoras de mangues, são destacadas como Área de Preservação Permanente (APP). Segundo o artigo Art. 3ํㅜ para os efeitos da Leio $12.651 / 2012$, entende-se por:

(...)VIII - restinga: depósito arenoso paralelo a linha da costa, de forma geralmente alongada, produzido por processos de sedimentação, onde se encontram diferentes comunidades que recebem influência marinha, também consideradas comunidades edáficas por dependerem mais da natureza do substrato do que do clima. A cobertura vegetal nas restingas ocorrem mosaico, e encontra-se em praias, cordões arenosos, dunas e depressões, apresentando, de acordo com o estágio sucessional, estrato herbáceo, arbustivos e arbóreo, este último mais interiorizado.

Figura 5: Vegetação de restinga.

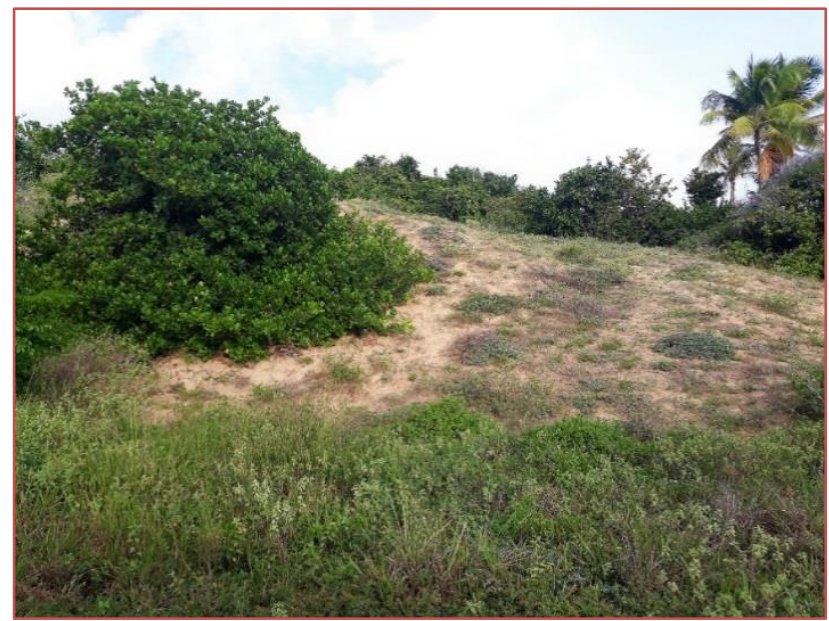

Fonte: Trabalho de campo, 2018. 
Para Araújo, Lages, Aguiar (2012), o ritmo acelerado das ações antrópicas é o principal causador das mudanças das condições naturais dos ecossistemas, que atualmente atinge excessivamente as APPs. Como exemplo, a nossa área de estudo encontra-se parcialmente degradada devido a constância das ações antrópicas, no entanto é notável a presença de áreas verdes resistentes (Figura 6).

Figura 6: Faixa de vegetação a margem da via urbana.

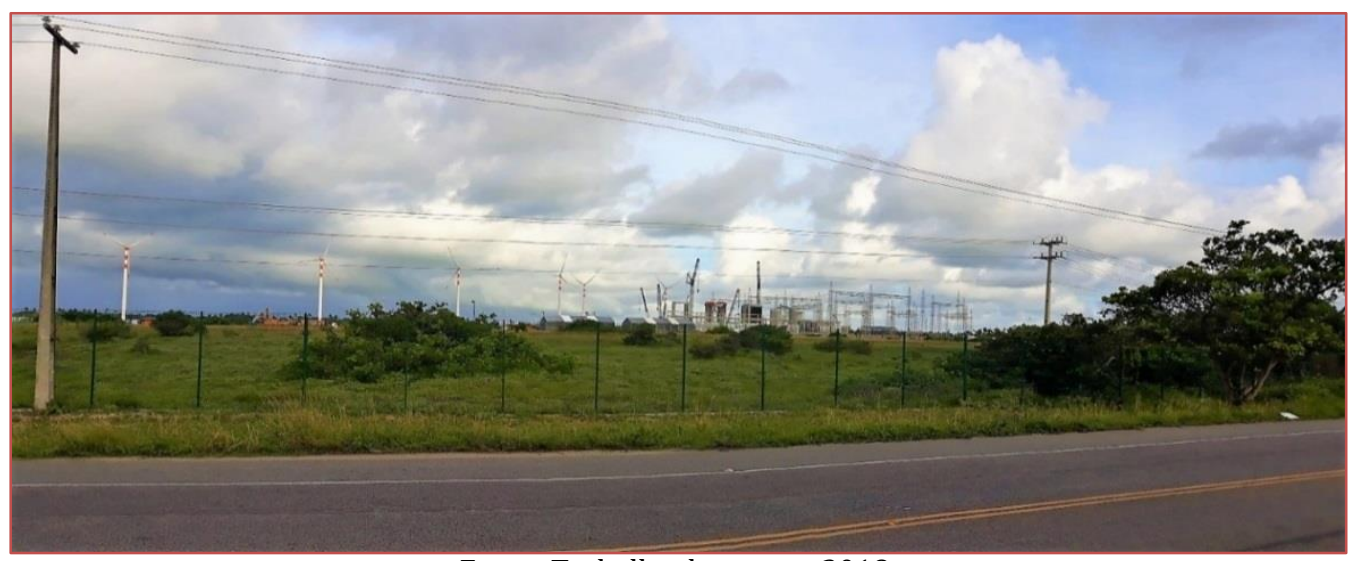

Fonte: Trabalho de campo, 2018.

Segundo os relatórios analisados, é afirmado que somente uma faixa de areia da praia (aproximadamente 0,2 hectares) houve a necessidade de intervenção das APPs - constituída por restinga arbustiva/arbórea fixadora de dunas (Figura 7). 0 fato não foi observado durante as visitas "in loco", havendo contradições de informação, visto que em todo CTPS e seu entorno existem diversas áreas de restinga, mesmo que em pequenas quantidades.

Figura 7: APPs localizada na área de construção dos dutos

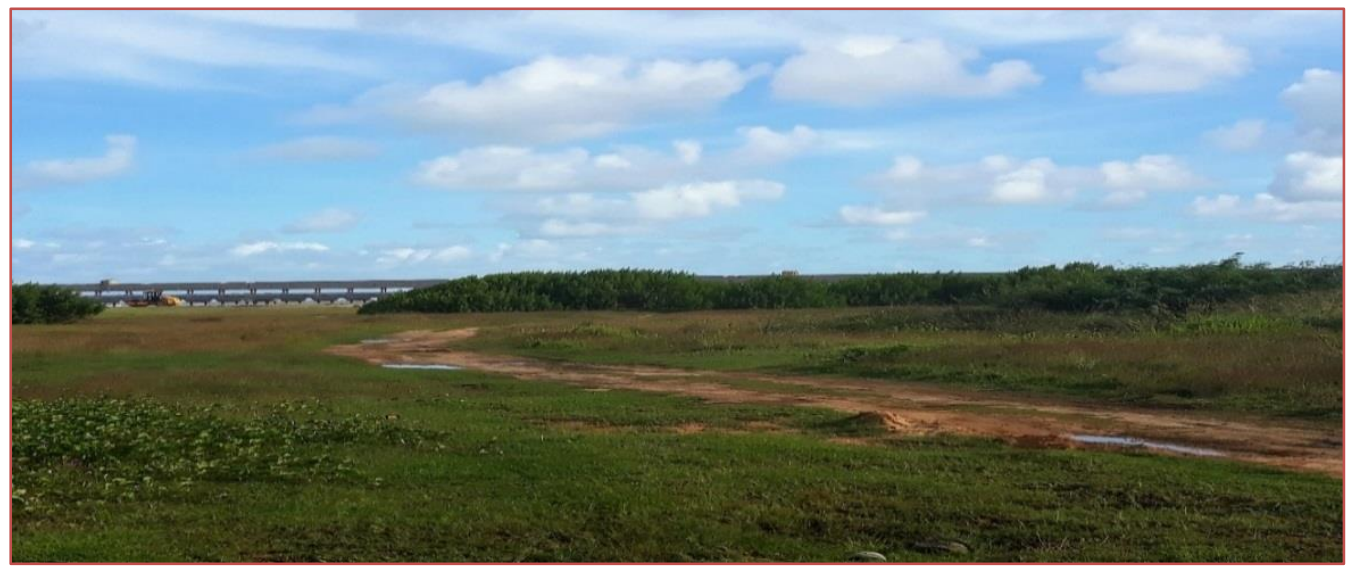

Fonte: Trabalho de campo, 2018.

As APPs que estão presentes na Linha de Transmissão, que ligará o complexo a subestação Jardim (percorrerá por 34,2 Km os municípios de Nossa Senhora do Socorro, Barra dos Coqueiros, Santo Amaro de Brotas e Laranjeiras) e a Unidade offshore de regaseificação, não serão apresentadas nesse estudo, pois o processo construtivo não foi iniciado até a presente data de elaboração deste trabalho.

\subsection{ASPECTOS E IMPACTOS SOCIOAMBIENTAIS DAS COMUNIDADES CIRCUNVIZINHAS AO CTPS}

As entrevistas foram realizadas nas áreas de influência direta (AID), que consiste no espaço geográfico onde as relações sociais, culturais, econômicas e os aspectos físicos e biológicos sofrem os impactos de maneira primária, onde terão suas características alteradas (CEPEMAR, 2004). 
A comunidade Cajueiro está localizada na margem oposta a área onde está sendo implantado o CTPS, situada entre a rodovia SE-100 e as áreas do mangue. Essas ocupações, geralmente, são construções irregulares, ocupadas há aproximadamente 9 anos por moradores ligados ao Movimento de Homens e Mulheres Sem Teto e Sem Terra do Estado de Sergipe (MHOMTESE) (Figura 8).

Figura 8: Área de influência direta - Comunidade Cajueiro

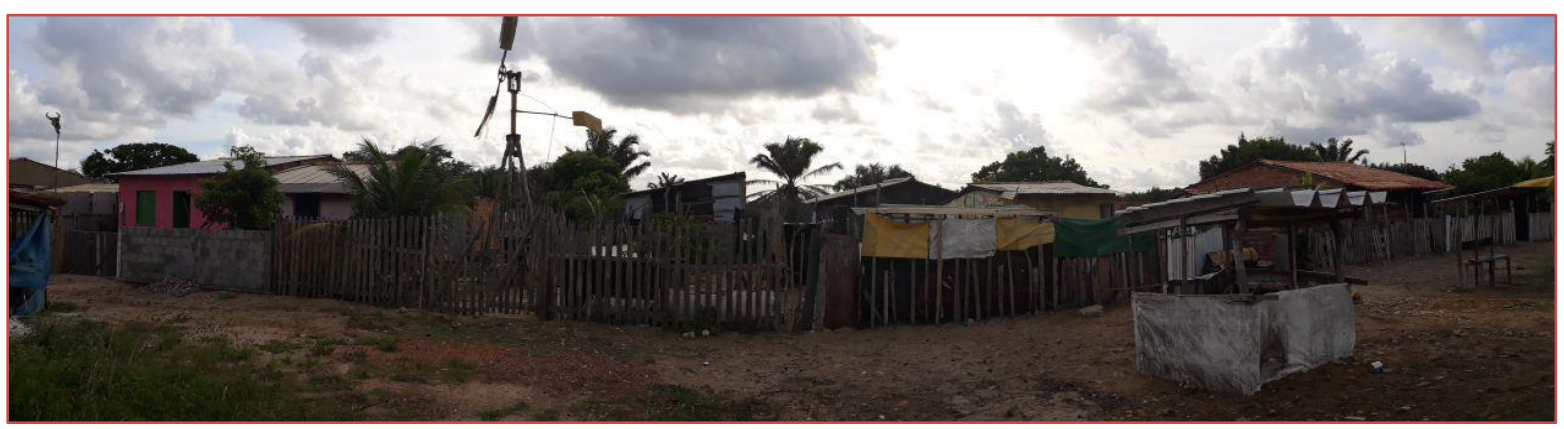

Fonte: Trabalho de campo, 2018.

Os entrevistados para preenchimento dos questionários, de acordo com o perfil socioambiental, eram moradores fixos da região, com faixa etária variável entre 25 e 68 anos (Figura 9). Os moradores demonstraram satisfação com a construção do CTPS, conforme relatado em suas falas, destacando-se a seguinte frase "a melhoria das vendas e emprego pra nossa gente".

Figura 9: Área de influência direta - Comerciante da comunidade Praia do Porto

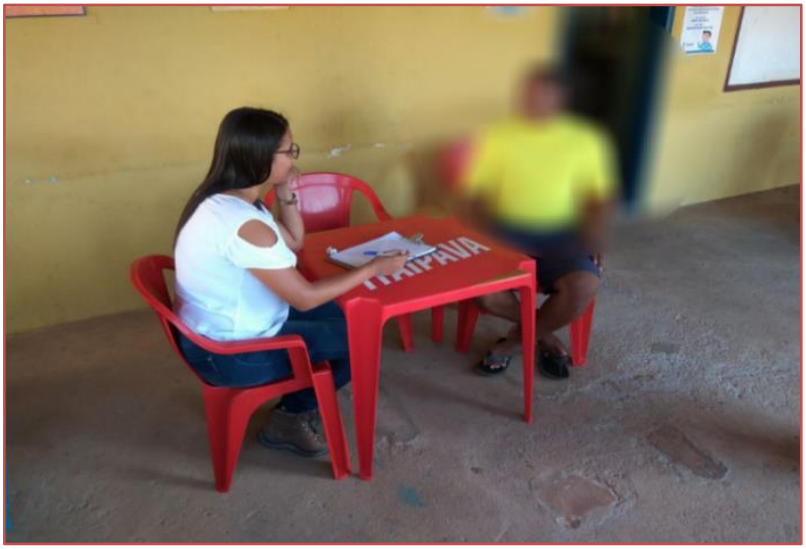

Fonte: Trabalho de campo, 2018.

Os resultados apontam que $60 \%$ dos entrevistados afirmaram que a população está ciente que o empreendimento em construção naquela região será uma usina termelétrica, e que o objetivo será a geração de energia (Figura 10). Para Castelli (2003), a geração de energia está relacionada ao desenvolvimento econômico e social de um país, o que torna importante o suprimento de energia, preservando o meio ambiente, e mantendo a sintonia entre geração energética e novas tecnologias. 
Figura 10: Entrevista - A população está ciente do tipo de obra que está sendo implementada?

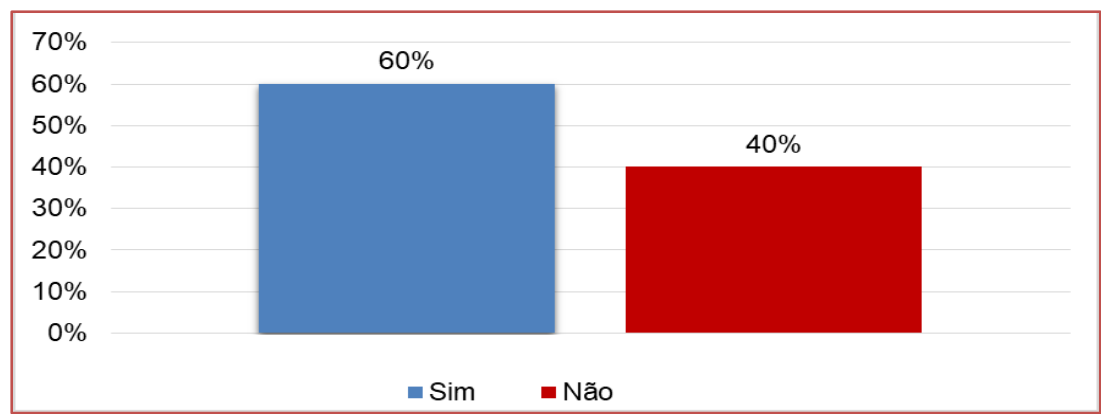

Fonte: Dados obtidos através da pesquisa de campo, 2018.

A divulgação sobre o complexo termoelétrico por parte da incorporadora é realizada através de cartazes nos estabelecimentos comerciais para conhecimento da população (Figura 11).

Figura 11: Cartazes em estabelecimentos comerciais.

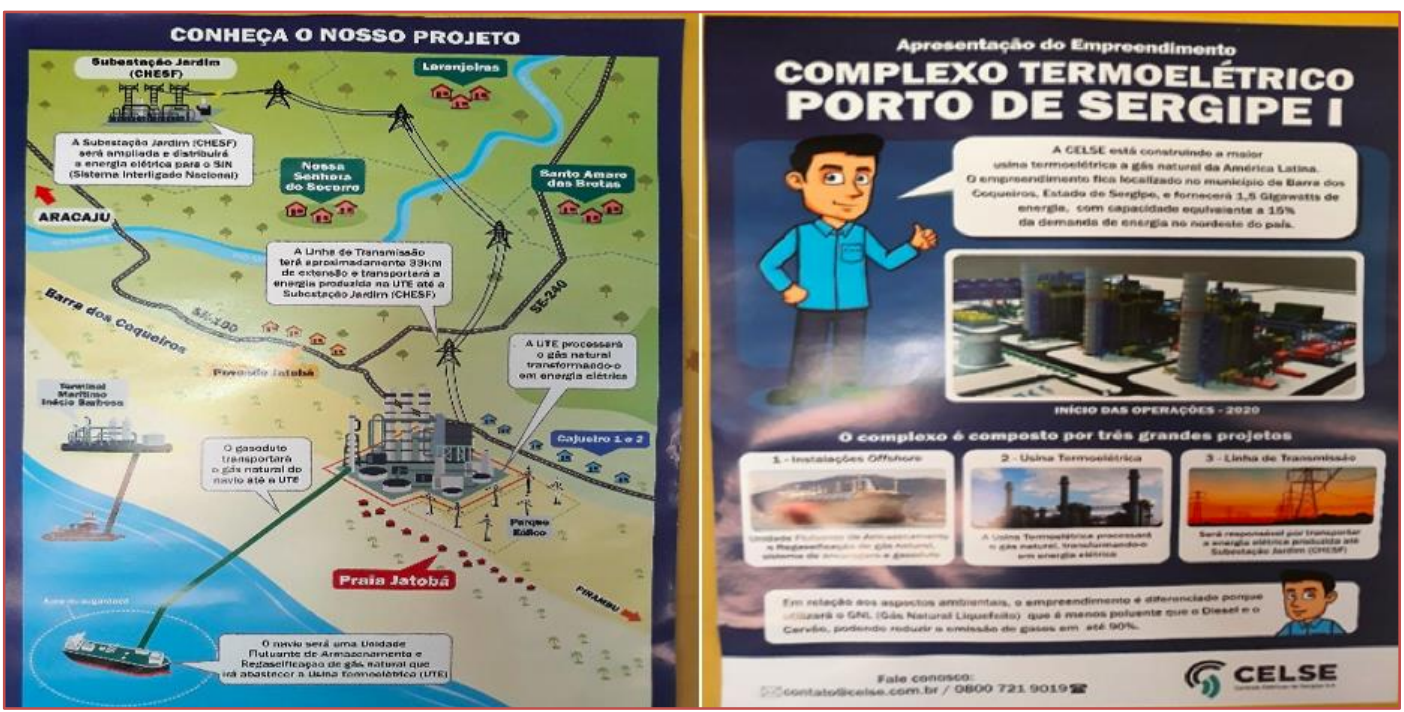

Fonte: Trabalho de campo, 2018.

Contudo, 65\% dos entrevistados não sabiam quais os tipos de impactos ambientais são ocasionados durante sua fase de instalação e posterior operação do CTPS (Figura 12). Desse modo, as poucas informações obtidas pela população foram explanadas superficialmente e as comunidades adjacentes estão leigas no quesito informação sobre impactos ambientais. De acordo com Carvalho (2000), a informação é um conjunto de dados, que, quando transmitidas da maneira e no tempo adequado, amplia o conhecimento do receptor e habilita a desenvolver melhor determinada atividade ou a tomar decisões melhores.

Figura 12: Entrevista - A população está ciente dos tipos de impactos ocasionados pelo empreendimento?

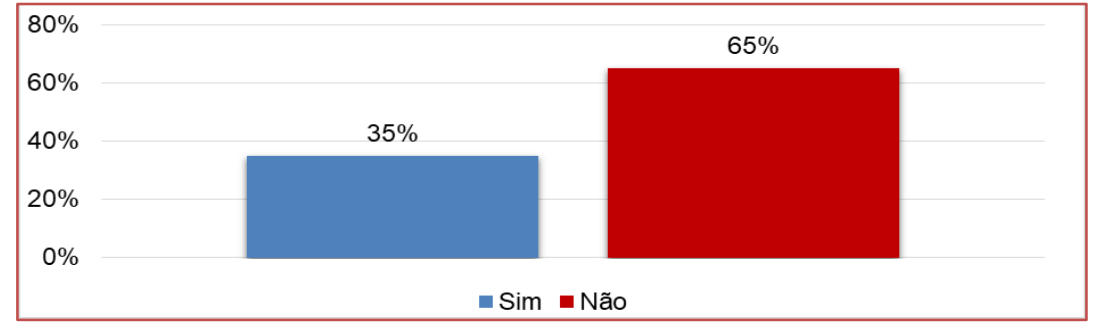

Fonte: Dados obtidos através da pesquisa de campo, 2018. 
Segundo dados analisados, 75\% dos entrevistados (Figura 13) afirmaram que houve algum tipo de abordagem ou pesquisa social, econômica e/ou ambiental, realizadas a partir de audiências públicas, divulgadas através de carros de som e panfletos distribuídos em pontos comerciais das comunidades (Figura 14). Durante as audiências foram realizados cadastros socioeconômicos e cadastros para vagas de emprego.

Figura 13: Entrevista - Houve algum tipo de abordagem ou pesquisa social, econômica e/ou ambiental por parte da empresa incorporadora?

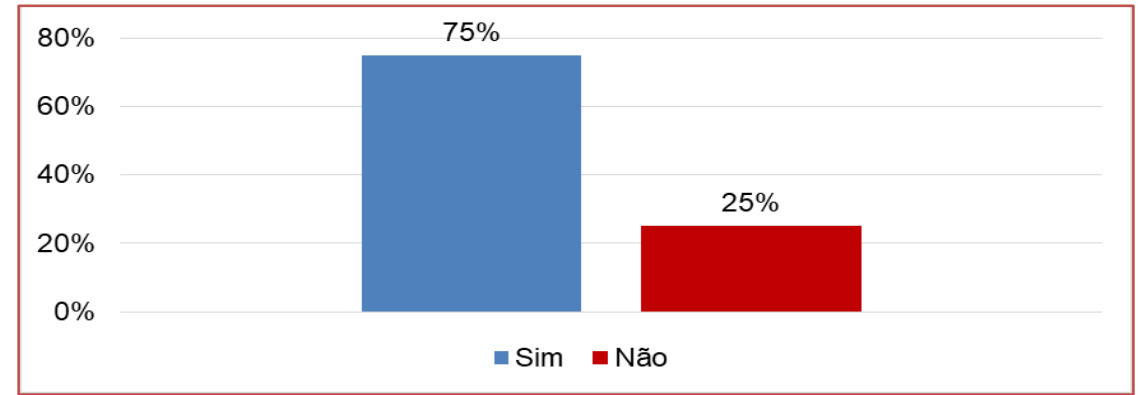

Fonte: Trabalho de campo, 2018.

Figura 14: Cartaz com informações em estabelecimento comercial

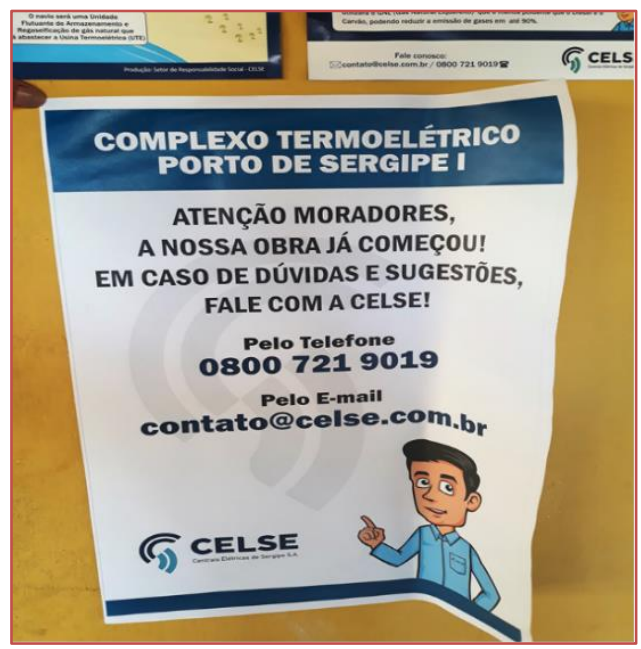

Fonte: Trabalho de campo, 2018.

Dentre as atividades realizadas no canteiro de obras, a mais perceptível entre $60 \%$ dos entrevistados foi o aumento da emissão de poeira, durante o processo de terraplanagem, o que causou bastante incômodo para os moradores (Figura 15).

Figura 15: Entrevista - Percebeu-se a presença de alguma atividade do canteiro de obra (ruído, poeira e vibrações) durante a instalação do Complexo Termelétrico?

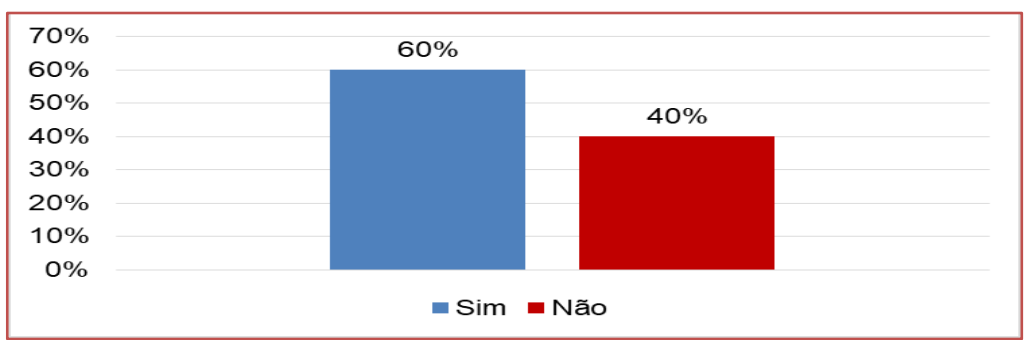

Fonte: Trabalho de campo, 2018. 
Para Canter (1977), impacto ambiental é toda e qualquer alteração ao meio ambiente seja ele no meio físico, químico, biológico, cultural e socioeconômico que seja atribuída a atividades humanas para satisfazer as necessidades de um projeto. Os resultados revelaram que $100 \%$ dos entrevistados afirmam que a redução de animais. Anteriormente eram encontrados com mais frequência na região, os mais citados por eles foram: várias espécies de aves, saguis, saruês, guaxinins, sapos e lagartos. Um dos aspectos para redução de algumas espécies se deve a presença do homem e a emissão de ruídos.

0 trânsito local sofreu um grande aumento na circulação de veículos, afirmaram 100\% doa entrevistados, sendo maioria transportes de cargas pesadas com materiais para a construção do CTPS e ônibus para os transportes dos trabalhadores, todavia ainda não observavam esse fato como um possível tipo de impacto ambiental.

Segundo dados analisados, 100\% dos entrevistados apontaram que nos dias de hoje não é perceptível a redução da área de dunas, visto que a área de construção do CTPS já havia sido terraplanada há muito tempo, informação confirmada pelos moradores mais antigos da região. Com relação as áreas de dunas nos arredores da área construída, foi observado redução ou degradação devido a crescente especulação imobiliária pelas construtoras no município. Os campos de dunas possuem uma importância fundamental para o equilíbrio das zonas costeiras, pois fornece sedimentos para rios e/ou praias, alimentando-as, direta ou indiretamente. Desta maneira, o processo de migração ao longo da costa, as dunas controlam e regulam o balanço sedimentar de todo o ambiente costeiro (PINHEIRO, 2009).

De acordo com 100\% dos entrevistados, não houve até o momento da realização das entrevistas a implementação de programas socioambientais, ainda que nos relatórios analisados, a empresa incorporadora afirma a elaboração e a prática dos mesmos durante a fase de construção e operação CTPS. Para Goldberg (2001), a responsabilidade socioambiental das empresas está traçada em dois princípios básicos: a atividade empresarial deve gerar valor para o meio ambiente e a sociedade, e o segundo que o desafio da economia global sustentável é possível.

Ainda que $80 \%$ do total de entrevistados afirmaram que o benefício econômico foi o que mais se destacou, gerando desenvolvimento da região, principalmente com o aquecimento do comércio e serviços (Figura 16). Todavia, a maioria está insatisfeita com a demanda de vagas de emprego para as comunidades, pois acreditavam que devido ao tamanho do empreendimento e o recebimento de incentivos fiscais pela empresa incorporadora, as vagas de emprego seriam absorvidas, em maioria, pelos trabalhadores da região.

Figura 16: Entrevista - A implantação do Complexo Termelétrico trouxe benefício econômico?

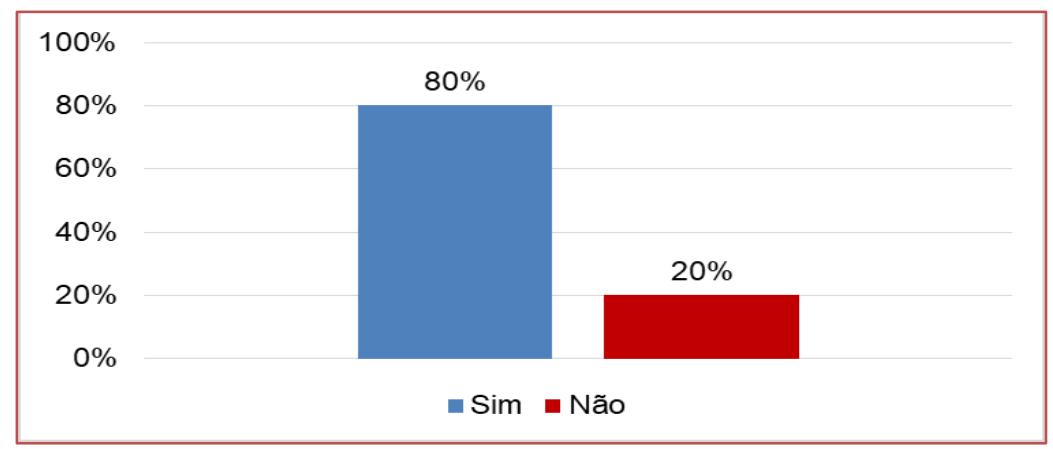

Fonte: Dados obtidos através da pesquisa de campo, 2018.

Para Oliveira (2012), a indústria da construção civil interfere diretamente no desenvolvimento econômico e contribui para o desenvolvimento regional relacionados a diversos fatores do setor, como a geração de empregos e mudanças na economia.

Além desses aspectos, os entrevistados apontaram expectativas futuras com a instalação do CTPS, como: melhorias no saneamento básico dos loteamentos, melhoria da estrutura das tendas (onde são vendidos produtos colhidos pelos moradores) ao longo da SE-100, criação de projetos para construção de orla nas praias, criação de creches para as crianças da comunidade, melhorias no acesso da SE-100 até a praia, como asfalto e iluminação pública, dentre outros.

Segundo a NBR ISO 14.001 Brasil (2005, p. 2): 
Aspecto ambiental é o elemento das atividades, produtos ou serviços de uma organização que pode interagir com o meio ambiente. NOTA - Um aspecto ambiental significativo é aquele que tem ou pode ter um impacto ambiental significativo. Impacto ambiental qualquer modificação do meio ambiente, adversa ou benéfica, que resulte, no todo ou em parte, das atividades, produtos ou serviços de uma organização.

Segundo Degani (2003), os impactos ambientais são consequência dos aspectos ambientais decorrentes das atividades desenvolvidas pelas empresas. Diversos aspectos ambientais poderam ser encontrados durante a construção de um empreendimento. 0 trabalho analisou os seguintes aspectos, seguindo o modelo de Degani (2003):

- Remoção de edificações;

- Supressão da vegetação;

- Ocupação da via pública;

- Emissão de vibração;

- Emissão de ruídos;

- Emissão de material particulado;

- Consumo e desperdício de água;

- Emprego de mão de obra;

- Mudança de uso de imóvel;

- Estímulo ao comércio local.

Por meio dos aspectos foram identificados os impactos aos meios físico, biótico e antrópico. Os impactos são:

a) meio físico - solo

- Alteração das propriedades físicas;

- Indução de processos erosivos;

- Esgotamento de reservas minerais.

b) Meio físico - ar

- Deterioração da qualidade do ar;

- Poluição sonora.

c) Meio físico - água

- Alteração da qualidade águas;

- Aumento da quantidade de sólidos;

- Alteração da qualidade das águas subterrâneas;

- Alteração dos regimes de escoamentos;

- Escassez de água.

d) Meio biótico

- Interferências na fauna local;

- Interferências na flora local;

- Alteração da dinâmica dos ecossistemas locais;

e) Meio antrópico - vizinhança

- Alteração da qualidade paisagística;

- Alteração no tráfego de vias locais;

- Incômodo para a comunidade;

- Alteração nas condições de saúde; 
- Danos a bens edificados;

- Melhoria da economia do município;

- Geração de emprego e renda;

A partir das observações "in loco" a matriz foi preenchida através dos impactos ambientais mais relevantes (Figura 17).

Figura 17:Matriz Aspectos \& Impactos ambientais observados no CTPS

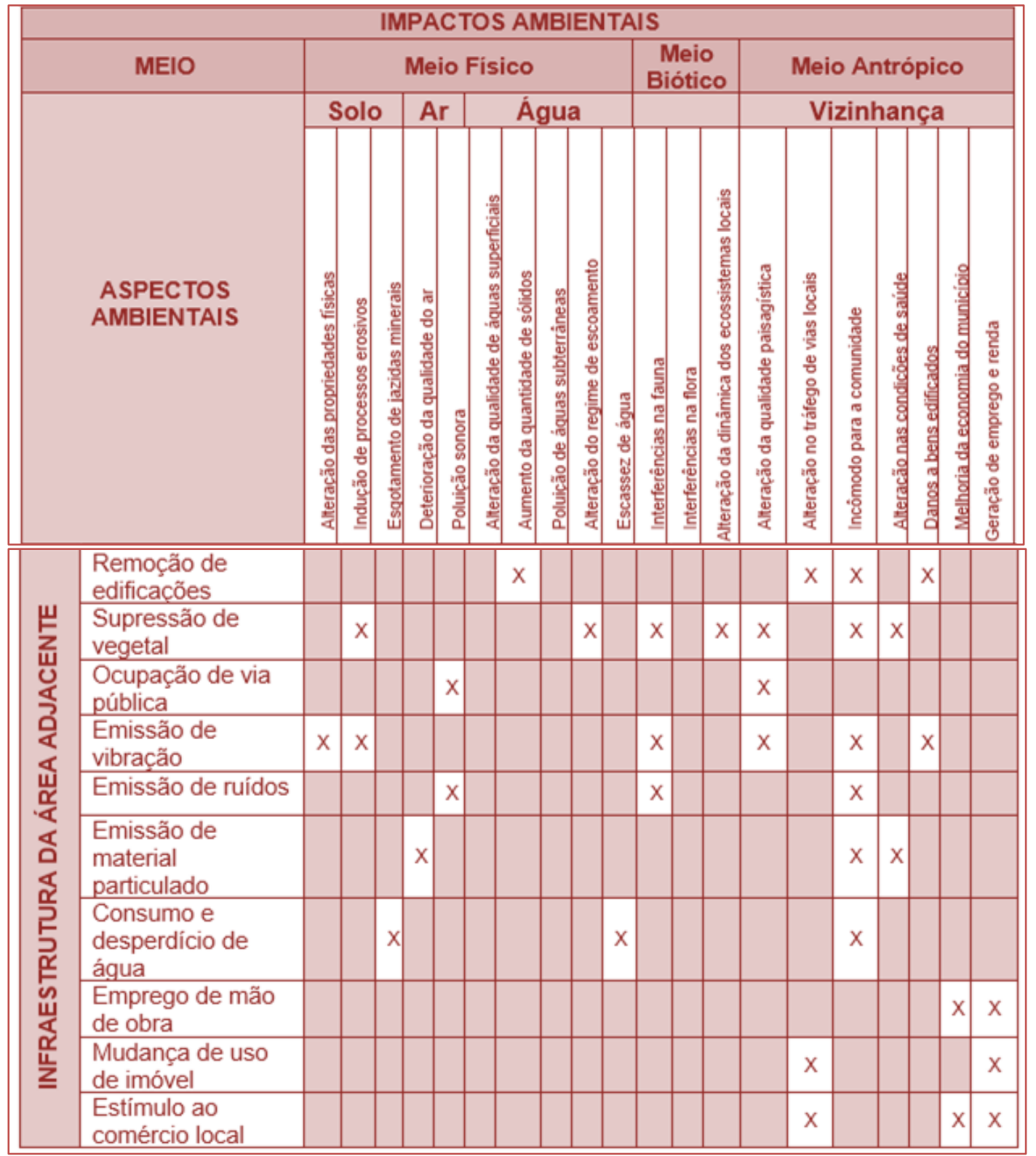

Fonte: Adaptado de (DEGANI, 2003). Legenda: X - Impactos mais relevantes.

0 modelo adotado para esta pesquisa realizou-se através dos aspectos ambientais mais significativos durante o processo construtivo e que exercem maior influência nos meios físico, biótico e antrópico para possíveis impactos ambientais. 0 aspecto ambiental de maior influência foi a supressão de vegetação (Figura 18). 
Figura 18: Avaliação de aspectos ambientais.

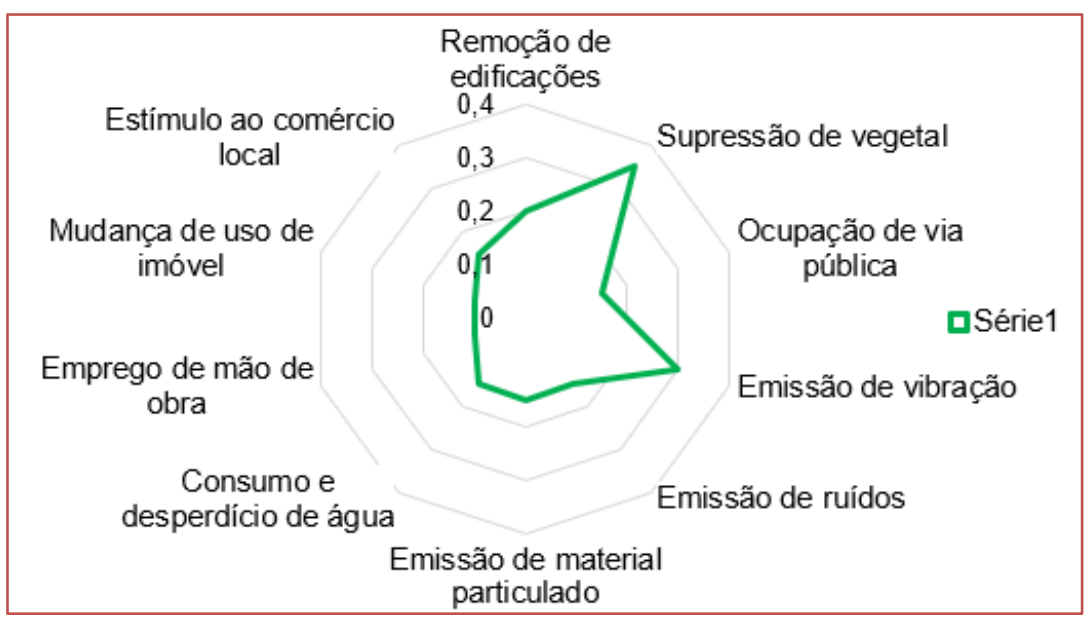

Fonte: Trabalho de campo, 2018.

Já com relação aos impactos ambientais mais significativos durante o processo construtivo e que exerceu maior impacto no meio antrópico foi o incômodo para as comunidades adjacentes (Figura 19).

Figura 19: Avaliação de impactos ambientais- meio antrópico.

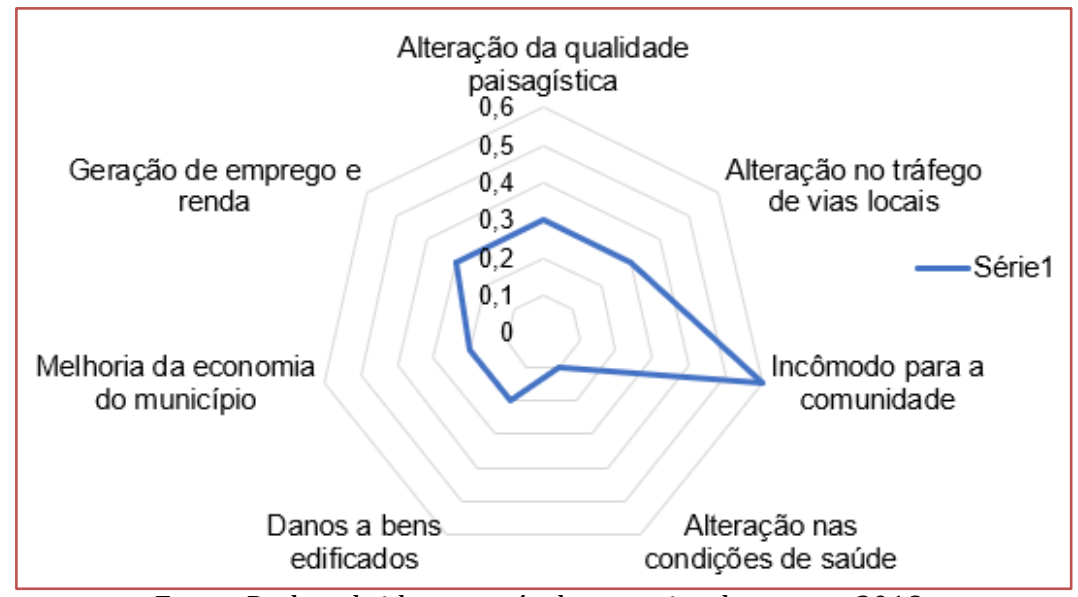

Fonte: Dados obtidos através da pesquisa de campo. 2018

\section{CONSIDERAÇÕES FINAIS}

Na perspectiva das comunidades adjacentes ao Complexo Termoelétrico Porto de Sergipe, durante o processo construtivo, o principal aspecto positivo foi a geração de empregos e o desenvolvimento da economia local. Os impactos ambientais, na perspectiva dos moradores, foram o aumento da emissão de poeira, aumento no tráfego de veículos e redução da presença de animais silvestres. Outro fato observado in loco que contradizem os relatórios emitidos é que, apesar da área já ter sido degradada há muito tempo, a presença de vegetação nativa e APP's ao entorno do complexo são notavelmente significativas. Todavia, de modo geral, os órgãos competentes optam por liberarem as licenças ambientais, pois recuperá-lo tornase inviável economicamente.

Por fim, ainda que existam numerosos órgãos ambientais em diversas instâncias (municipal, estadual e federal), o setor de fiscalização encontra-se deficiente e não é capaz de conduzir a demanda do setor da construção civil. Por conseguinte, faz-se necessário a melhora contínua dos órgãos de fiscalização, através da promoção de avaliação periódicas dos impactos socioambientais, a fim de assegurar uma relação equilibrada entre o meio ambiente, as comunidades adjacentes e as construtoras. 


\section{REFERÊNCIAS}

[1] ASSOCIAÇÃO BRASILEIRA DE NORMA TÉCNICAS. NBR 14.001: Sistemas de gestão ambiental - Especificação e diretrizes para uso. Rio de Janeiro, 1996. Disponível em: <http://www.madeira.ufpr.br/disciplinasghislaine/iso14001-2004.pdf> Acesso em: 26 de março de 2018.

[2] ANTUNES, P. B. Direito Ambiental. 5.ed. Rio de Janeiro: Lumen iuris, 2001.

[3] ARAÚJO, C.B.F.; LAGES, V.D.; AGUIAR, V.G. III Congresso Brasileiro de Gestão Ambiental Goiânia/GO - 19 a 22/11/2012.Disponível em <http://www.ibeas.org.br/congresso/Trabalhos2012/VI-001.pdf IBEAS> Acesso em:21 de março de 2018.

[4] CELSE. Estudo Ambiental Complementar Complexo Termelétrico Porto do Sergipe. Rev 00, de 04/05/2017.

[5] BRASIL, Ministério do Meio Ambiente. Conselho Nacional do Meio Ambiente. Resolução n 01, de 23 de janeiro de 1986.Dispõe sobre critérios básicos e diretrizes gerais para avaliação de impactos ambientais. Brasília/DF: DOU, 1997.Disponível em: <http://www.mma.gov.br/port/conama/legiabr e.cfm?codlegi=23> Acesso em: 10 de maio de 2018.

[6] BRASIL, Ministério do Meio Ambiente. Política Nacional do Meio Ambiente. Lei no 6.938, de 31 de agosto de 1981. Dispõe sobre a Política Nacional do Meio Ambiente, seus fins e mecanismos de formulação e aplicação, e dá outras providências. Brasília-DF: DOU,2000 Disponível em: <http://www.planalto.gov.br/ccivil_03/Leis /L6938.htm > Acesso em: 26 de março de 2018.

[7] BRASIL, Ministério do Meio Ambiente. Novo Código Florestal. Lei no 12.651, de 25 de maio de 2012. Dispõe sobre a proteção da vegetação nativa. Brasília-DF. Disponível em: < http://www.planalto.gov.br/ccivil_03/_Ato20112014/2012/Lei/L12651.htm> Acesso em: 26 de março de 2018.

[8] CANTER, L. W. Environmental Impact Assessment. New York: McGraw-Hill Book, 1977. Disponível em: <https://pt.scribd.com/doc/180399907/Environmental-Impact-Assessment-by-L-W-Canter>. Acesso em: 12 de abril de 2018.

[9] CARVALHO, Rodrigo Baroni de. Tecnologia da informação aplicada à gestão do conhecimento. Belo Horizonte: Editora Arte, 2000.

[10] CASTELLI, Aldo.Energia para gerações. Rio de Janeiro, 2003. Disponível em:<http://www.shell.com/home/content/bra/aboutshell/media_centre/annual_reports _and_publications/book_energy/>. Acesso em: 25 abril de 2018.

[11] CEPEMAR, Áreas de influência da atividade. In: EIA - Estudo de impacto ambiental do campo de Jubarte. Brasil: Rev. 00, 2004.

[12] DEGANI, Clarice M. Sistemas de gestão ambiental em empresas construtoras de edifícios. São Paulo.2003. 223f. e anexos. Dissertação (Mestrado) - Escola Politécnica da Universidade de São Paulo. São Paulo, 2003.Disponível em:< http://docplayer.com.br/5432836-Clarice-menezes-degani-sistemas-de-gestao-ambiental-em-empresasconstrutoras-de-edificios.html>. Acesso em: 11 de março de 2018.

[13] FERREIRA, Paulo. O sistema de licenciamento ambiental e o desafio econômico - proposta para o estado de São Paulo.2010. 244 f. Tese (Doutorado) - Curso de Engenharia, Universidade de São Paulo, São Paulo, 2010.

[14] GIL, Antônio Carlos. Métodos e Técnicas de Pesquisa Social. 6aㅡ Ed. São Paulo: Atlas, 2008.

[15] GOLDBERG, Ruth. Como as empresas podem implementar programa de voluntariado. São Paulo: Instituto Ethos, 2001. Disponível em: <https://pt.scribd.com/document/73788526/Goldberg-Ruth-Como-as-empresaspodem-implantar-Programas-de-Voluntariado-2001. Acesso em: 10 de março de 2018

[16] PINHEIRO, M. V. A. Evolução Geoambiental e Geo-histórica das Dunas Costeiras de Fortaleza, Ceará. Dissertação (Mestrado em Geografia). Universidade Federal do Ceará, 2009. Fortaleza, 2009.

[17] OLIVEIRA, Valéria Faria. O papel da Indústria da Construção Civil na organização do espaço e do desenvolvimento regional. Congresso Internacional de Cooperação Universidade-Indústria. Taubaté (SP), 2012.

[18] REIS, Jorge Luiz Britto Cunha. Licenciamento Ambiental. Disponível em: <http://rodoviasverdes.ufsc.br/files/2010/04/Licenciamento-ambiental.pdf> Acesso em: 20 de abril de 2018.

[19] SANCHES, Roberta. A avaliação de impacto ambiental e as normas de gestão ambiental da série ISO 14000 : características técnicas, comparações e subsídios à integração. Dissertação apresentada à Escola de Engenharia de São Carlos da Universidade de São Paulo. São Carlos, 2011. 


\section{Capítulo 4}

\section{Compatibilização de projetos empregando modelos parametrizados - Concepções da modelagem BIM}

\section{Danilo Leite Almeida de Sá \\ Jorge Eduardo Fontes Leite}

Resumo: 0 presente trabalho tem por objetivo demonstrar a importância da compatibilização de projetos empregando modelos parametrizados baseados na Building Information Modeling - BIM para o setor da construção civil. Por meio de pesquisa bibliográfica, buscou-se uma melhor compreensão da ferramenta (BIM), seus benefícios, interoperabilidade, nível de desenvolvimento LOD, fluxo básico do processo e modelagem. Para melhor entendimento do estudo, foi construído um modelo virtual em três dimensões com área total construída de 44,52 $\mathrm{m}^{2}$ utilizando o Autodesk Revit 2018, com o objetivo de realizar uma compatibilização dos projetos: arquitetônico, estrutural, elétrico, hidráulico e sanitário. Assim, foi possível realizar a compatibilização entre os projetos executados em ambiente virtual, através da parametrização dos objetos gerados por software BIM, evidenciando-se, portanto, a materialização de um projeto mais confiável e consistente, com uma maior economia de tempo e dinheiro.

Palavras-chave: Compatibilização de Projetos. Modelos BIM. Parametrização de Objetos. 


\section{INTRODUÇÃO}

Os sistemas baseados em CAD, assim como os sistemas adotados anteriormente - o desenho na prancheta - estão suscetíveis a enorme possibilidade de falhas na quantificação das partes do objeto. Quando ocorre qualquer alteração em uma vista do desenho, imediatamente e manualmente, deve ser feita a correção nas demais vistas, a fim de manter coerência na informação representada.

$\mathrm{O}$ advento da tecnologia BIM transformou essa realidade, pois esse tipo de situação desaparece. Na plataforma BIM a representação de um objeto, não ocorre em planos, e sim no espaço tridimensional digital, onde qualquer vista do objeto será gerada a partir do modelo em 3D e as atualizações do modelo serão automaticamente refletidas por todas as vistas.

A grande vantagem dessa tecnologia está na coordenação e compatibilização de projetos. Com ela, é possível representar todos os projetos em um mesmo modelo de arquitetura, podendo ainda incluir elementos com medidas reais, por meio de escala. As instalações representadas são mostradas em 3D, modeladas em software como o Revit, traz as dimensões reais, permitindo visualizar e identificar o espaço ocupado por elas.

Alguns softwares, como o Tekla BIMsight, trazem a possibilidade de detecção de conflitos de forma automática, conferindo ao projetista rápida visualização das eventuais intercorrências. Neste sentido a quantificação automática dos elementos e dos sistemas permite gerar relatórios de quantitativos mais precisos, eliminando a possibilidade de erros na compatibilização.

Tentaremos demonstrar aqui a relevância do uso da tecnologia BIM para o setor da construção civil, no campo dos projetos, dadas as enormes vantagens oferecidas por ela. Um projeto construído dentro da plataforma BIM provê grande fidelidade e coordenação entre os elementos elaborados, o que reduz custo, em razão da previsão do resultado, permitindo uma tomada de decisão preventiva, na ocorrência de alguma incompatibilidade.

O objetivo geral desse trabalho é demonstrar de formas simples e clara como a utilização de software, com o conceito BIM, pode ajudar a construção civil na elaboração de projetos, com maior precisão, e detalhamento dos espaços ocupados por cada objeto, assim diminuir os conflitos entre projetos antes que avancem para a fase de construção.

\section{METODOLOGIA}

0 trabalho em estudo foi desenvolvido pelo método bibliográfico, por meio da revisão da literatura e criação de um modelo BIM.

Segundo Mota e Ruschel (2016), a revisão da literatura trata da busca, análise e descrição sempre procurando respostas às perguntas específicas; desta forma, podemos afirmar que a revisão da literatura percorrer todo cabedal à cerca dos materiais disponíveis considerados relevantes sobre o tema.

Por se tratar de um trabalho bibliográfico, foi desenvolvido um projeto demonstrativo, a fim de atender aos objetivos propostos neste estudo (Figura 1). 
Figura 1: Imagem 3D do modelo BIM

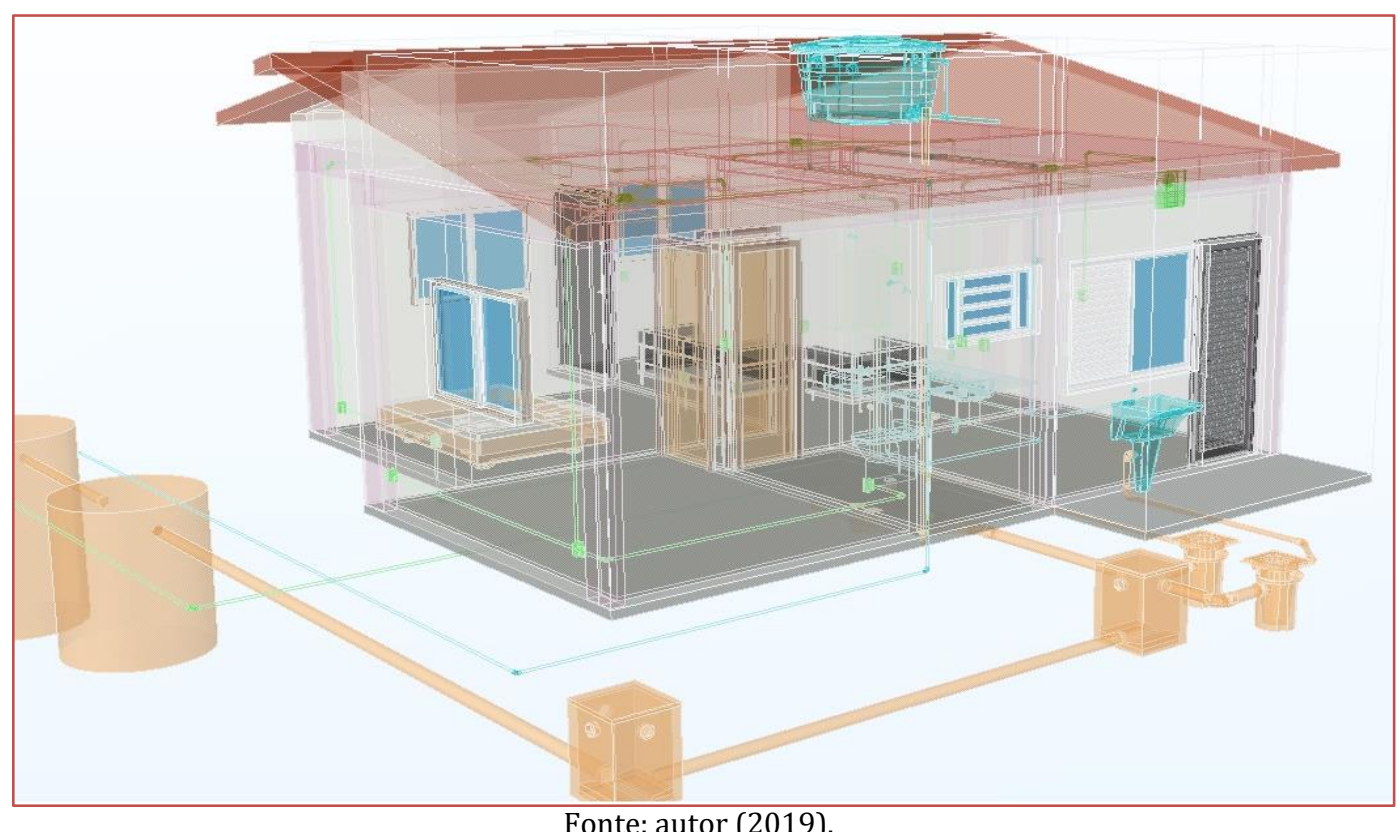

O desenvolvimento do projeto arquitetônico foi elaborado no Autodesk Revit 2018 utilizando a biblioteca, de elementos parametrizados, existente no próprio software e na plataforma online da Autodesk, para isso lançamos mão da NBR 6492/1994 para nortear o desenvolvimento da planta baixa e de todos os itens do projeto arquitetônico.

Utilizando como referência a planta baixa, foram elaborados os seguintes projetos: projeto estrutural, projeto elétrico, projeto sanitário e projeto hidráulico.

0 processo de desenvolvimento do projeto estrutural revelou a necessidade de alteração das dimensões da seção das colunas e das vigas existentes na biblioteca do Revit 2018, tal modificação foi necessária para que os elementos estruturais pudessem ter mesma dimensão, e dos elementos arquitetônicos. A alteração, desses objetos, foi realizada com o editor de família no próprio software (Figura 2).

Figura 2: Editor de Família.

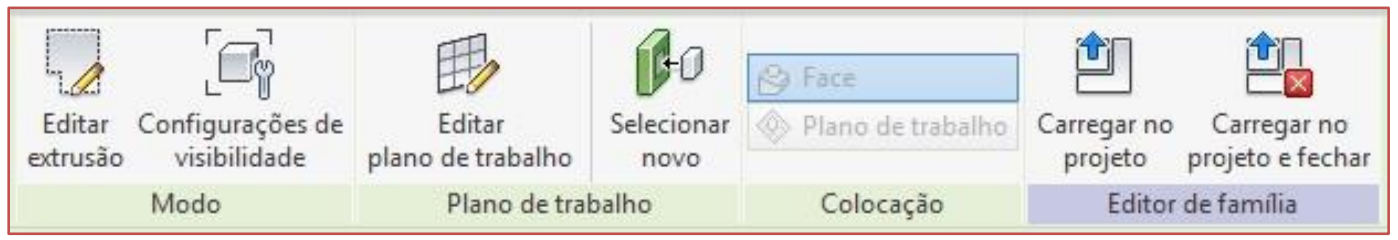

Fonte: Autodesk Revit (2018).

Cada projeto desenvolvido no Revit teve um arquivo IFC gerado e posteriormente exportado para o Tekla Bimsight, no qual após a inserção dos arquivos verificamos a existência de conflitos entre os projetos que foram identificados automaticamente pelo software. As inconsistências nos projetos foram analisadas de tal forma que se priorizou aquelas que afetassem o projeto estrutural, devido a maior complexidade para alteração. Os demais projetos elétrico, sanitário e hidráulico verificando a ocorrência de conflitos entre os mesmos.

A construção de um modelo BIM, em ambiente acadêmico, visando aplicar uma solução para diminuir os índices de retrabalho na construção civil por conta das falhas de projetos.

Por meio da terceira dimensão do BIM, fica evidente, quando se utiliza tecnologia de forma incisiva, passando por uso de software, obtém melhoria no controle de qualidade e nos processos de produção, rastreabilidades os insumos utilizados e treinamento constante da equipe. 
As informações coletadas foram geradas a partir do Revit 2018 compartilhadas com o Tekla por meio dos arquivos IFC com nível de detalhamento LOD 200, usando apenas as informações gráficas, deixando detalhes como quantitativos e orçamento à margem deste trabalho.

O projeto arquitetônico utilizado como base para desenvolver os demais projetos, tanto o estrutural, quanto complementares, é um projeto bastante simples pensado para servir de demonstração. Cada um dos projetos foi elaborado em arquivos individuais para que as detecções dos conflitos pudessem ser mais eficientes, permitindo ser executada conforme a necessidade, todos de uma vez só e em pares, otimizando assim a utilização do Tekla BIMsight, que nos permite estabelecer parâmetros norteadores para realizar a compatibilização entre projetos.

Para analisar os dados e alinha-los ao desenvolvimento do BIM com as melhores práticas para elaboração de projetos, foi idealizada uma residência de baixo padrão com 44,52 $\mathrm{m}^{2}$ de área construída, (Figura 3) na qual foi modelado utilizando o Revit 2018. A arquitetura segundo a NBR 6492, projeto estrutural em concreto armado conforme NBR 6118, projeto elétrico seguindo a NBR 5410, projeto hidráulico conforme NBR 5626 e projeto sanitário conforme NBR 8160.

Mesmo seguindo as especificações das NBR's citadas alguns conflitos entres os projetos foram colocados de forma intencional para servir de referência no momento da compatibilização dos projetos, através do software Tekla, com os arquivos IFC gerado pelo Revit 2018 de cada projeto.

Figura 3: Planta baixa

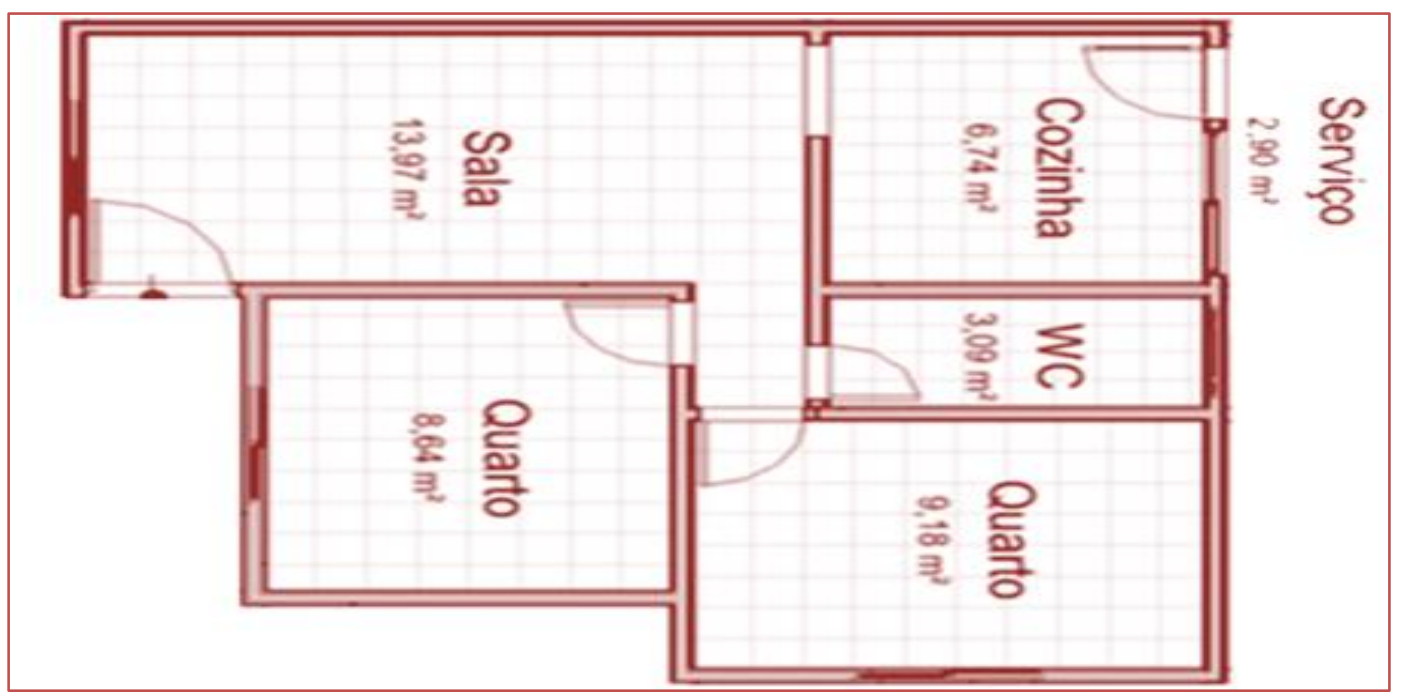

Fonte: autor (2019).

O planejamento, que foi pensado para este projeto, visa a compatibilidade, definindo como prioridade a compatibilização do projeto estrutural, o qual não deve sofrer alterações quanto ocorrer algum tipo de conflito com os demais projetos auxiliares. Para a melhor identificação dos possíveis conflitos e depuração do software a (Figura 4) mostra um ponto aonde os projetos elétricos (verde) e hidráulico (azul), entram em conflito. 
Figura 4: Conflito entre o projeto elétrico e o projeto hidráulico.

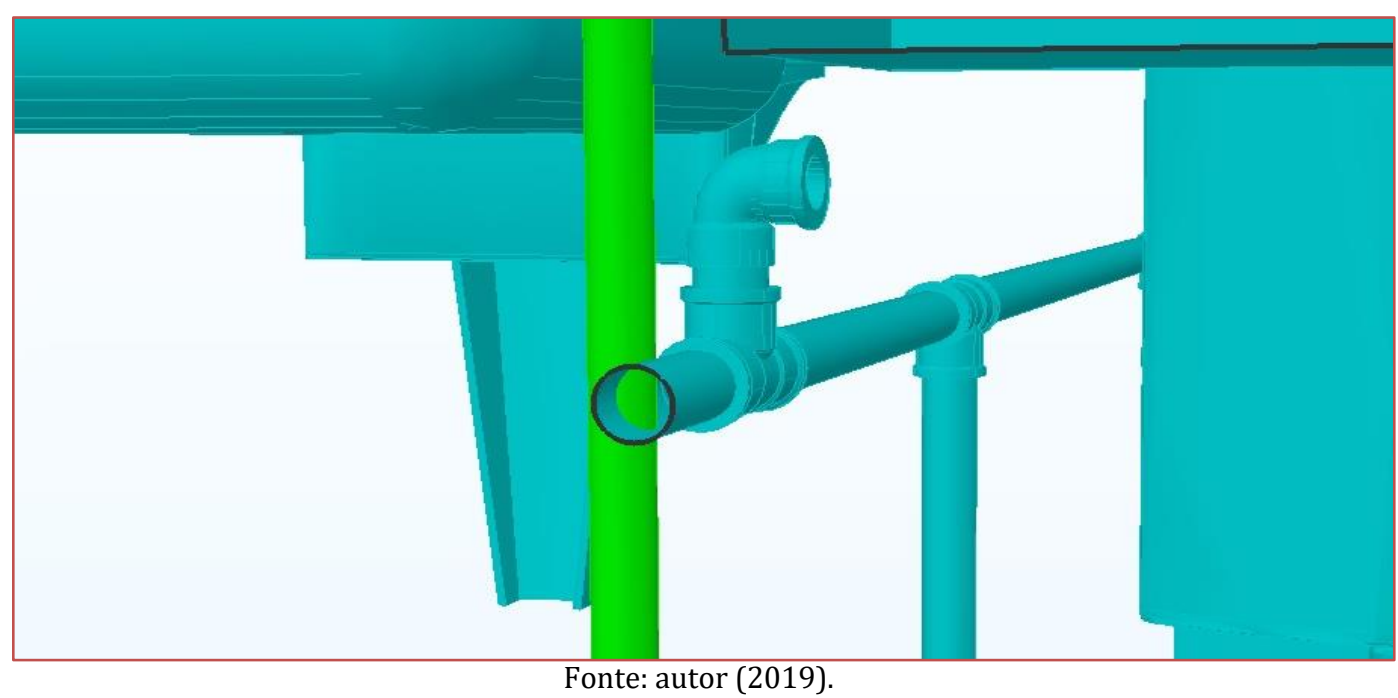

Um segundo conflito detectado entre o projeto elétrico e hidráulico, como mostra a (Figura 5), estes conflitos foram colocados de maneira intencional pelo autor, para servir de exemplo, pois outros conflitos foram detectados pelo software, os quais este autor não havia percebido previamente.

Figura 5: Conflitos nos ramais de entrada entre o projeto elétrico e o hidráulico

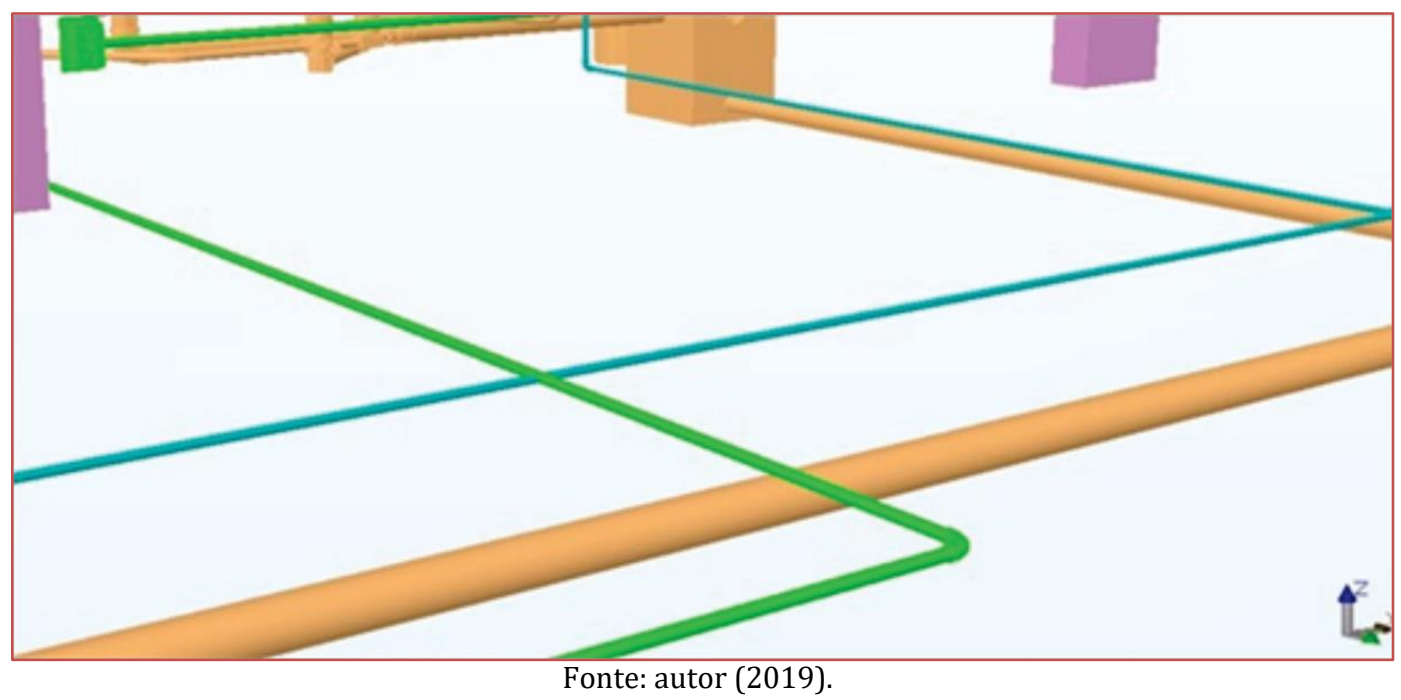

\section{RESULTADOS E DISCUSSÃO}

A necessidade de melhorar os processos de projetos na indústria da construção civil, vez que uma das causas de patologias com maior impacto na construção civil é a falha de projetos, busca criar condições para que esses problemas sejam minimizados ou mesmo extintos (Figura 6). 
Figura 6: Gráfico das causas das patologias na construção civil

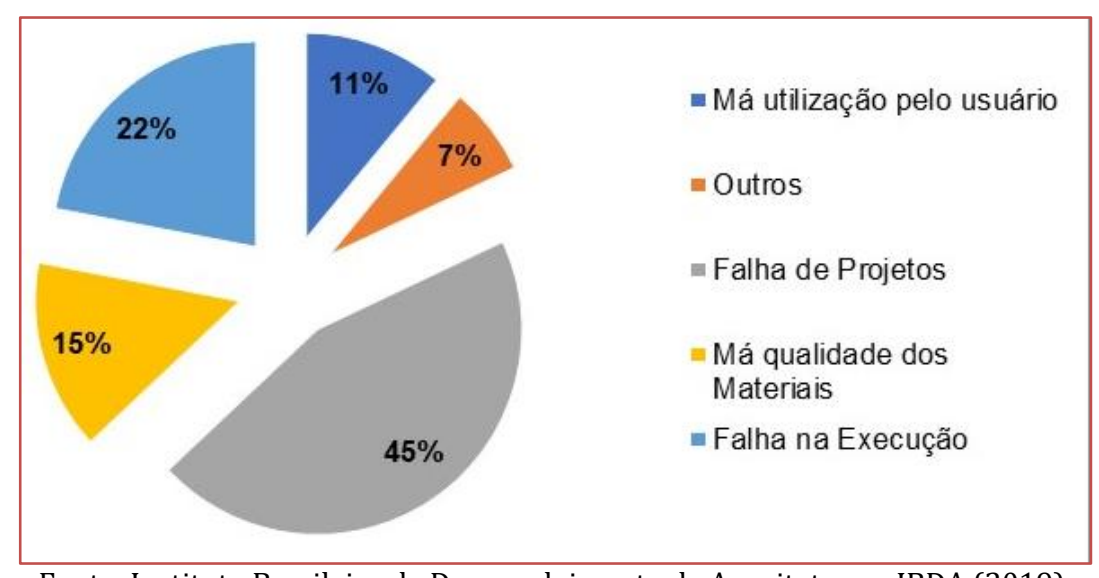

Fonte: Instituto Brasileiro de Desenvolvimento da Arquitetura - IBDA (2019).

Os arquivos exportados pelo Revit 2018 incluem dados da geometria do modelo, nível de detalhamento LDO 200 com significativas informações técnicas do projeto. Para desenvolvimento deste trabalho sob o conceito BIM era fundamental que os projetos, das disciplinas modeladas, pudessem ser compatibilizados, visando solucionar as interferências entre a estrutura de concreto armado, rede elétrica e rede hidrossanitária.

A interoperabilidade entre os softwares Revit 2018, gerando os arquivos IFCs, e o Tekla BIMsight que recebeu esses arquivos funcionaram com alto grau de precisão, não havendo perdas significativas de detalhes do projeto, como o posicionamento no espaço 3D, nem falta dos elementos que foram modelados.

A compatibilização por meio do Tekla BIMsight recebeu como regras principais de verificação para intercorrências a tolerância de sobreposição com $0,00 \mathrm{~mm}$ e distância mínima de 0,00 $\mathrm{mm}$ com a opção de procurar conflitos entre todos os objetos visíveis de disciplinas distintas (Figura 7).

Figura 7: Regras para encontrar conflitos. (Tekla BIMsight)

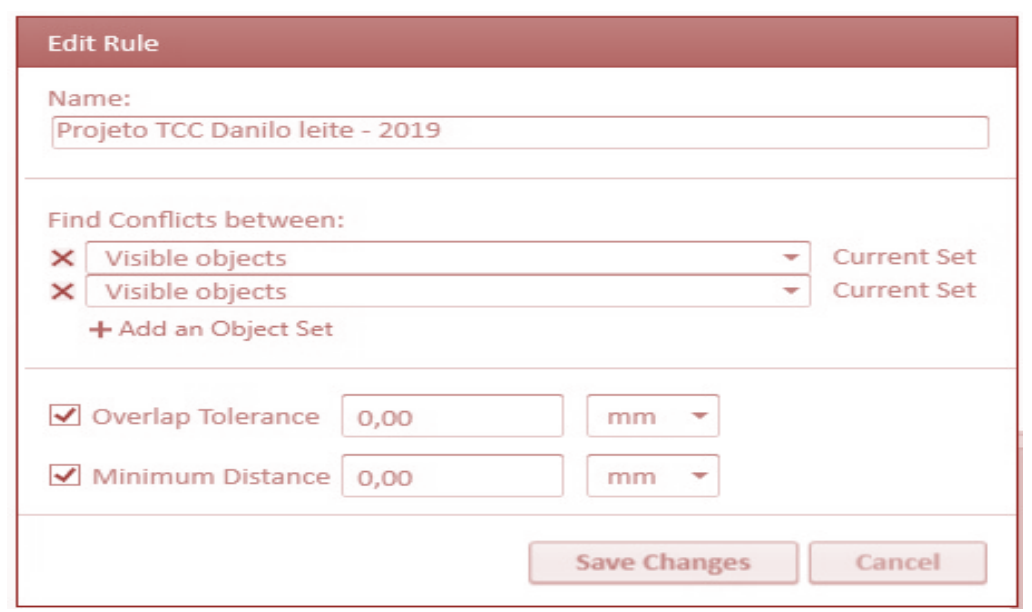

Fonte: autor (2019).

Foram encontradas um total de 54 intercorrências, sendo o projeto estrutural e o projeto elétrico com o maior número de casos de conflitos. Já o projeto arquitetônico e estrutural não houve nenhum conflito. Isto se deve ao processo de modelagem dos projetos o qual foi determinado uma espessura de parede de $0,15 \mathrm{~m}$ e sendo essa mesma medida para as vigas e pilares.

A (Figura 8) mostra uma viga com dois pontos de intersecção, sedo em direções opostas, aumentando, em um caso real, a possibilidade que essas intersecções encontrem o aço usado na viga de modo que este também sofra alguma alteração por conta deste conflito. 
Figura 8: Conflito crítico entre o estrutural e o elétrico.

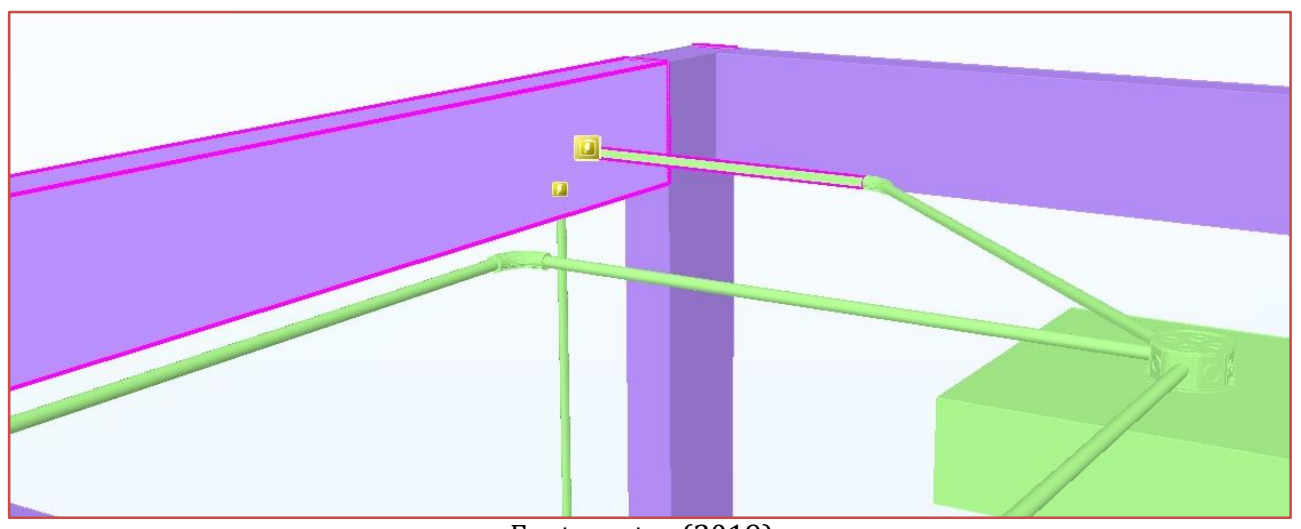

Fonte: autor (2019).

O projeto estrutural e o projeto hidráulico tiveram 17 intercorrências, sendo a maior parte delas consideradas suaves, devido a simplicidade em resolver o conflito, apenas uma apresentou grau mais alto de atenção, como mostra a (Figura 9), onde a tubulação desce por dentro do pilar, além de comprometer a estrutura de concreto armado, seria também um problema caso houvesse necessidade de algum tipo de reparo nesta parte da tubulação.

Figura 9: Conflito crítico entre o hidráulico e o estrutural.

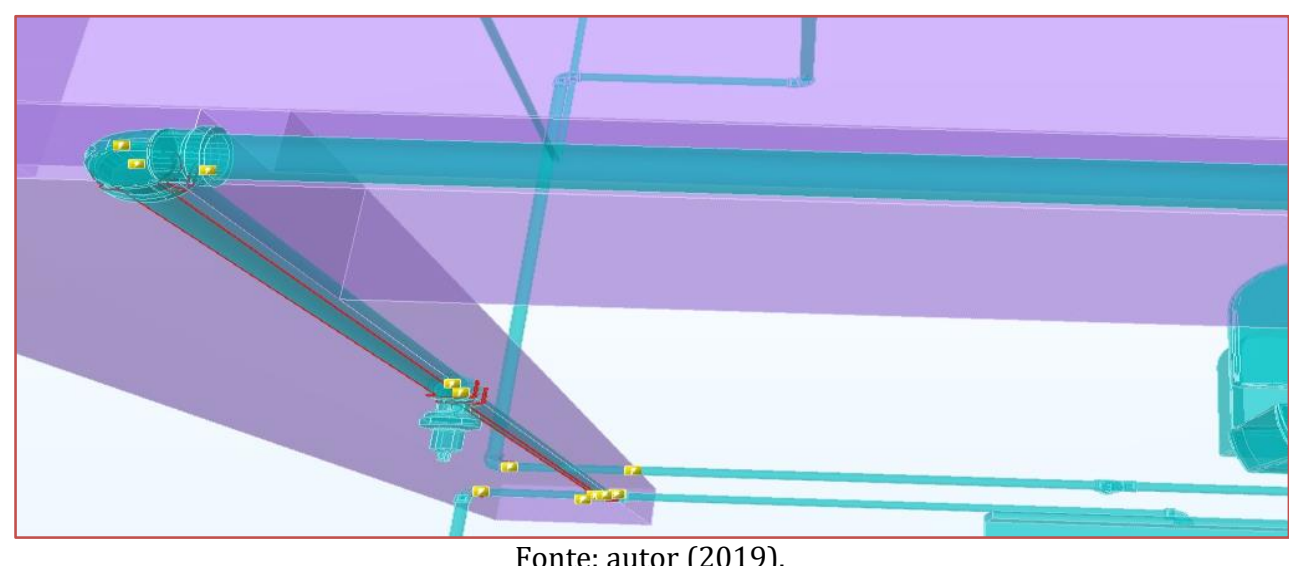

O projeto elétrico e o projeto sanitário como podemos ver na (Figura 10), não apresentaram nenhuma intercorrência. 
Figura 10: Ausência de conflito entre o projeto elétrico e hidráulico.

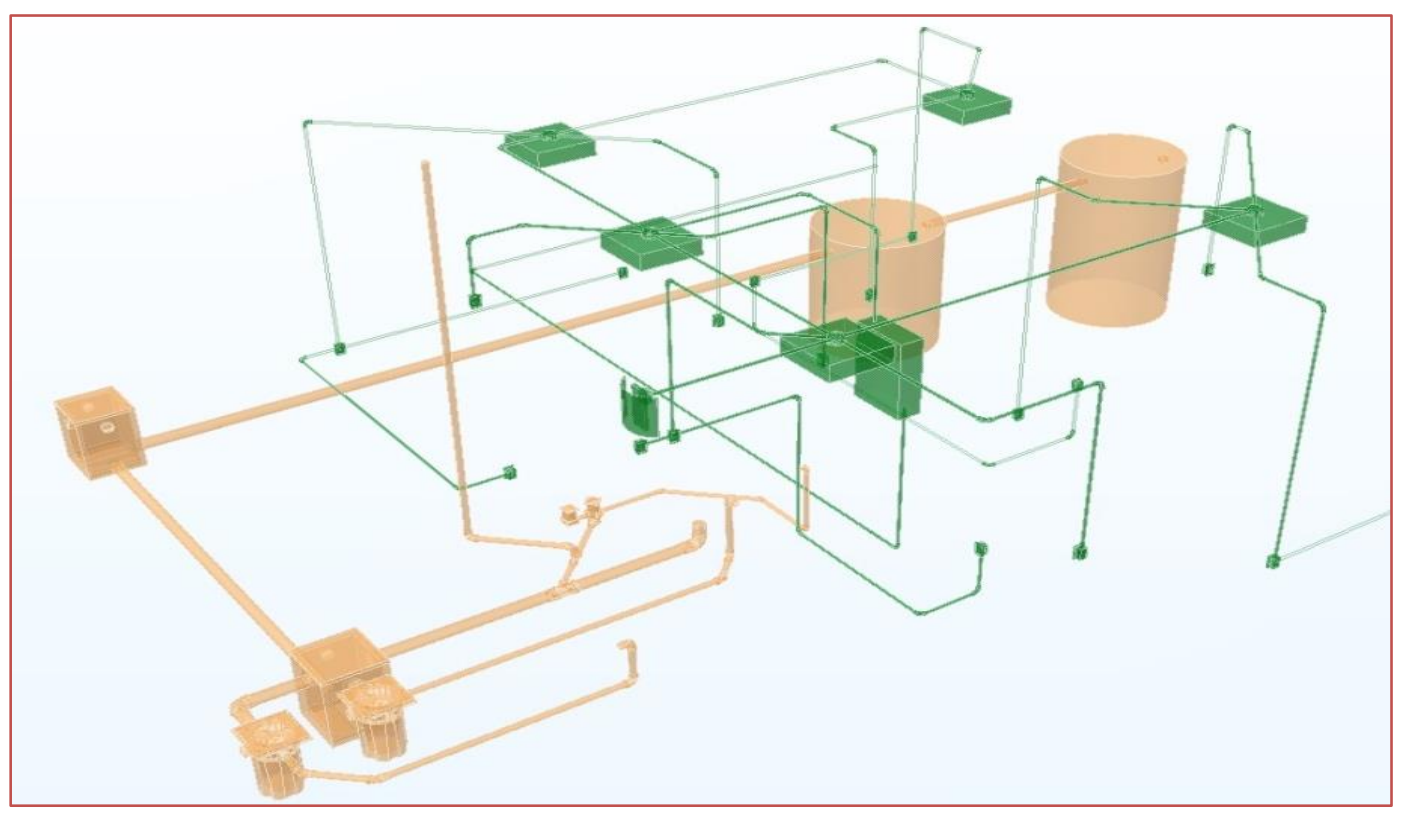

Fonte: autor (2019).

Foram detectados apenas dois conflitos entre o projeto estrutural e o projeto sanitário. Conforme (Figura 11), a tubulação sanitária secciona a parte estrutural nos elementos laje e viga, exigindo atenção para correção devida.

Figura 11: Conflito entre o projeto estrutural e o projeto sanitário.

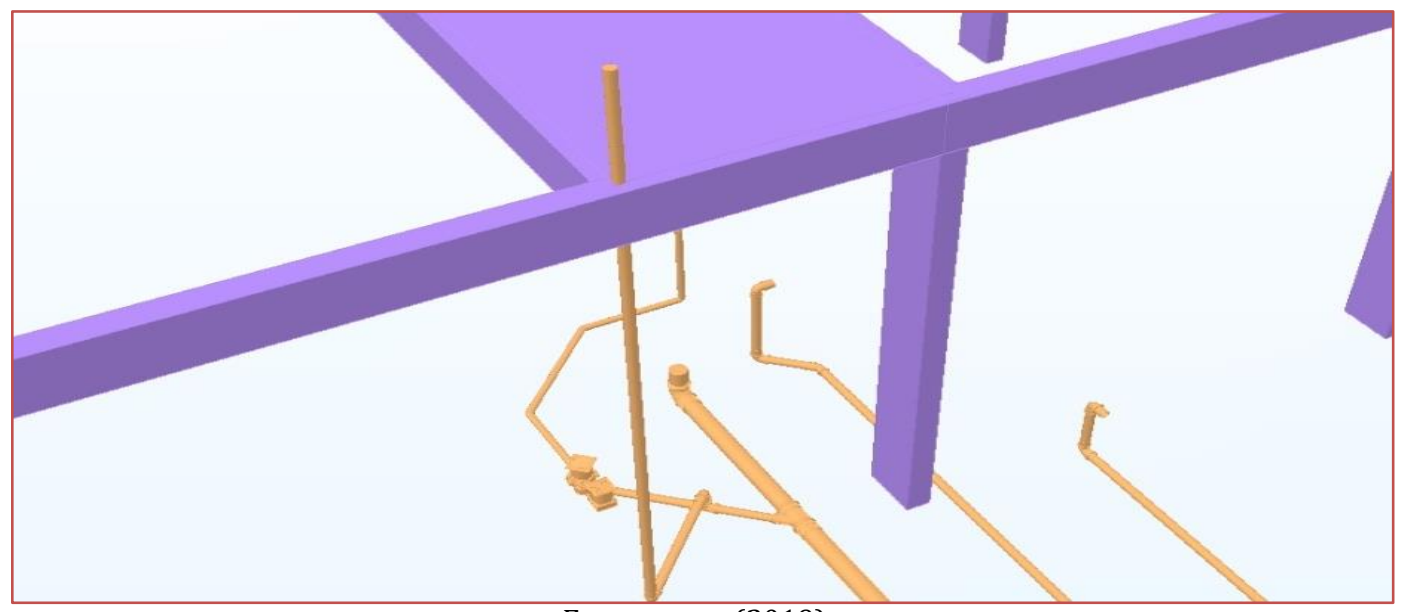

Fonte: autor (2019).

A (Figura 12) tem em destaque dois pontos de conflitos, onde o projeto sanitário entra em conflito com o projeto estrutural e o projeto hidráulico. Esse tipo de situação reforça ainda mais o conceito da colaboração entre os projetistas envolvidos, pois é possível que o conflito entre a parte hidráulica e sanitária seja agravado na tentativa de correção do conflito entre o sanitário e o estrutural. 
Figura 12: Conflito entre os projetos estrutural, sanitário e hidráulico

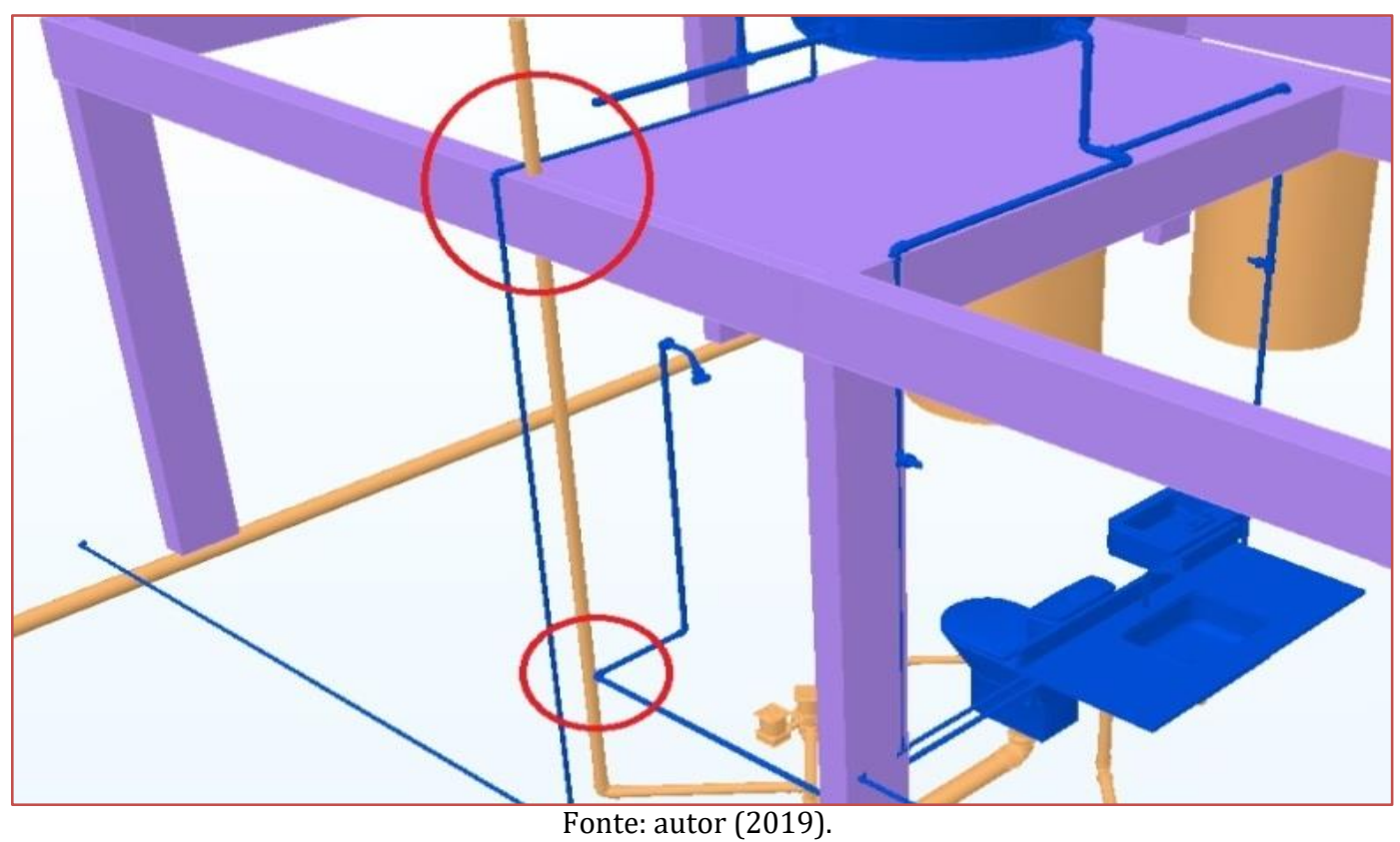

A (Tabela 1) foi criada para expor de forma mais concisa todos os conflitos e foram detectados neste projeto. A peculiaridade de cada tipo de construção faz com que o resultado obtido, neste trabalho, não seja um exemplo fiel a realidade. Com as dificuldades de cada projeto é possível e até mesmo provável que os projetos com maior número de conflitos sejam diferentes dos que aqui foram encontrados.

Tabela 1 - Ocorrência de conflitos entre os projetos.

\begin{tabular}{cc|c|c|c}
\multirow{2}{*}{ Projetos } & \multicolumn{5}{c}{ Ocorrência de conflitos } \\
& Suave & Médio & Crítico & Total parcial \\
\hline Estrutural / Elétrico & 5 & 19 & 8 & 32 \\
\hline Estrutural / Sanitário & - & - & 2 & 2 \\
\hline Estrutural / Hidráulico & 1 & 8 & 8 & 17 \\
\hline Hidráulico / Elétrico & - & 2 & - & 2 \\
\hline Hidráulico / Sanitário & - & 1 & - & 1 \\
\hline & Totais & & 54 \\
\hline
\end{tabular}

A estrutura projetada em concreto armado foi pensada da forma mais simples possível e não colocamos os detalhamentos do aço usado nas vigas, pilares e laje (Figura 13). 
Figura 13: Esquema do projeto estrutural

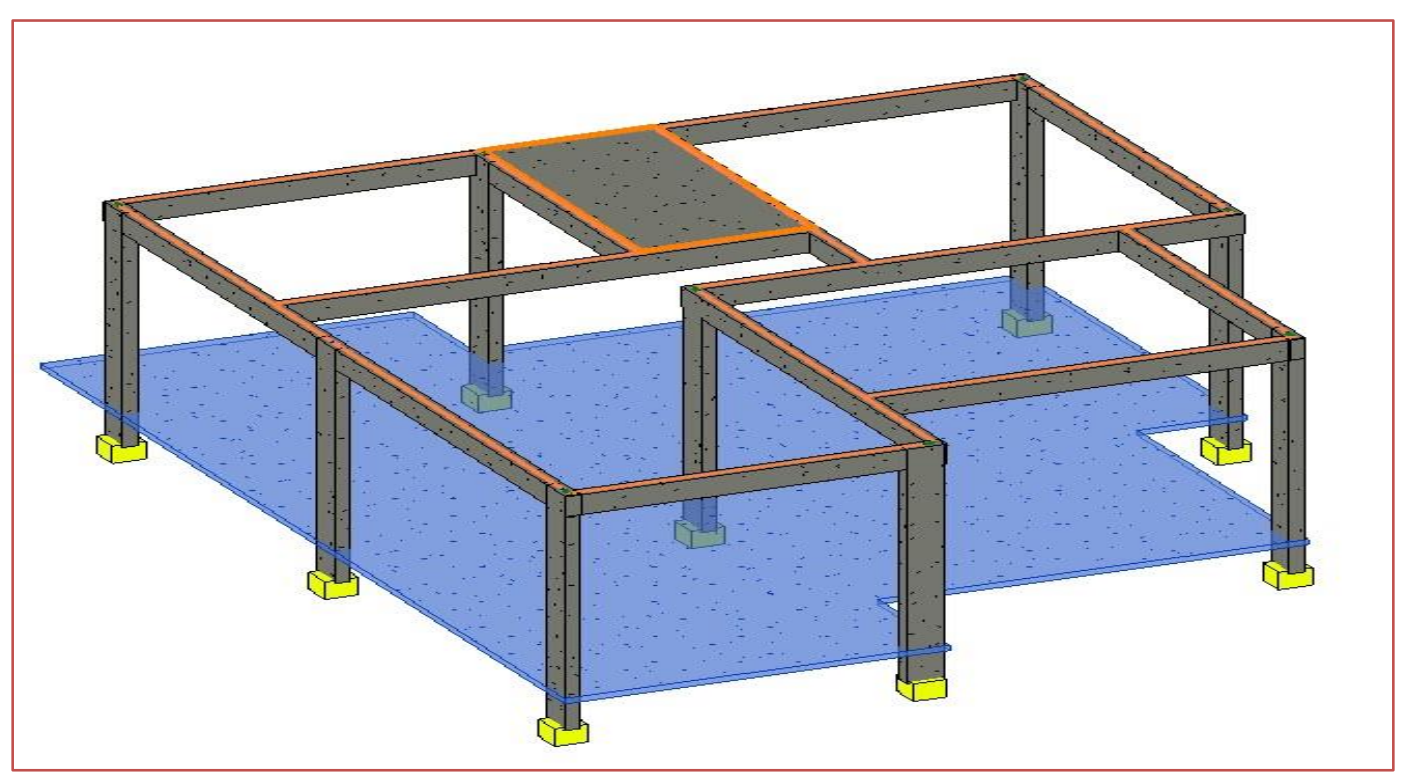

Fonte: autor (2019).

O projeto elétrico pode ser visualizado na (Figura 14), onde é exposto de forma esquemática sem o dimensionamento das tomadas, luminárias e interruptores.

Figura 14: Detalhe do projeto elétrico compatível com LDO 200

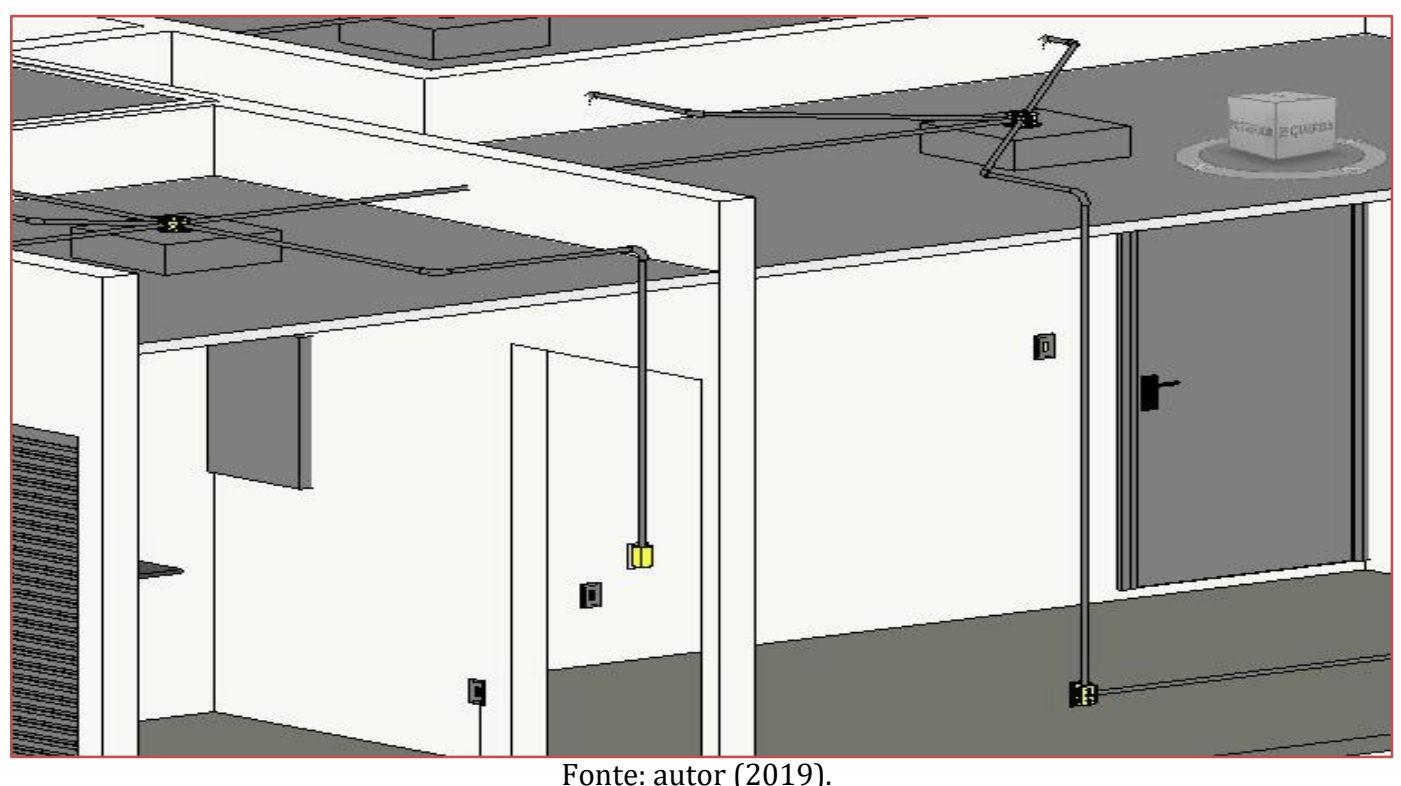

O nível de detalhamento do projeto elétrico é compatível com o LDO 200, na (Figura 14) pode ser visto detalhes das luminárias utilizadas, do tipo Plafon $300 \times 120 \mathrm{~mm}$, bem como os pontos de conexão dos conduítes e os detalhes dos interruptores de duas teclas em caixas $2 \times 4$ simples.

A apresentação do projeto hidráulico exibe o detalhamento do banheiro e da pia da cozinha com os respectivos pontos de saída de água (Figura 15). 
Figura 15: Projeto hidráulico.

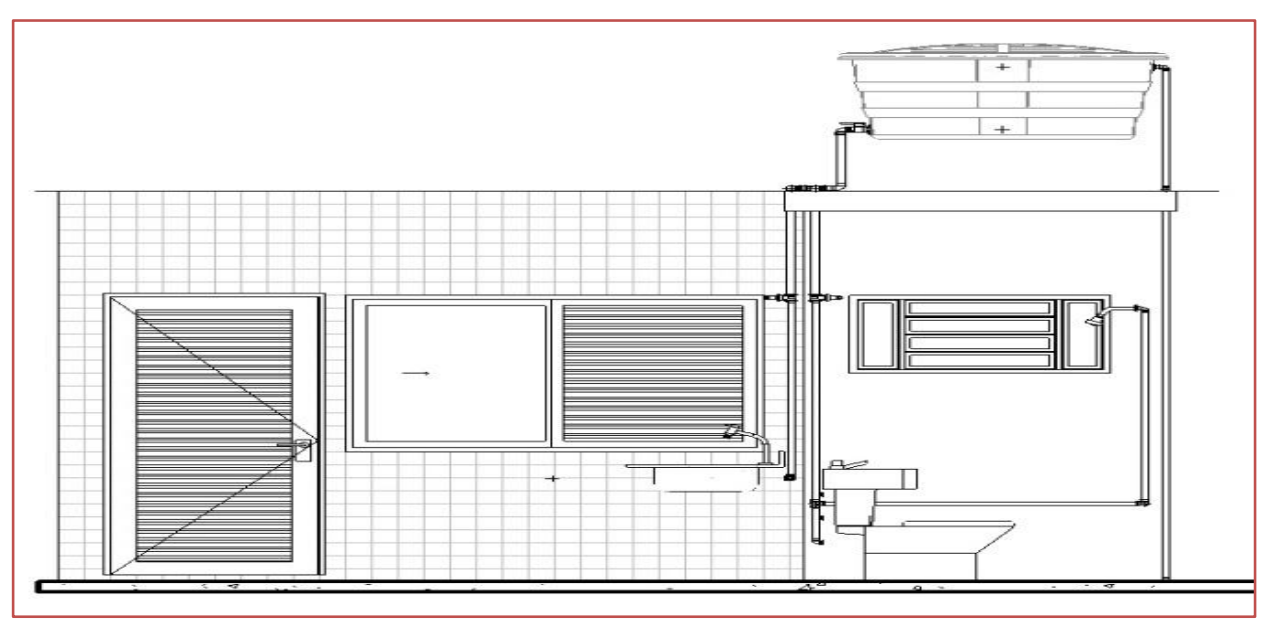

Fonte: autor (2019).

A caixa d'água está em uma posição acima da laje do banheiro para melhor visualizar o ponto de entrada de água (a direita da imagem) e o ponto de saída de água (a esquerda da imagem). Apesar de usados peças e conexões hidráulicas convencionais não foi realizado os dimensionamentos das tubulações, usou-se então as peças disponíveis na biblioteca padrão do Revit 2018, com algumas alterações nos diâmetros internos e externos para elaborar o projeto hidráulico como está apresentado.

O detalhe das peças usadas no projeto hidráulico, com nível de desenvolvimento LDO 200, tem destacado o reservatório, de capacidade 500 l para água fria, com os pontos prováveis de conexão tanto para entrada como para saída d'água (Figura 16). Ainda o destaque exibe a torneira boia para caixa d'água de $1 / 2$ ' e a montagem do extravasor.

Figura 16: Nível de detalhamento do projeto hidráulico compatível com LDO 200

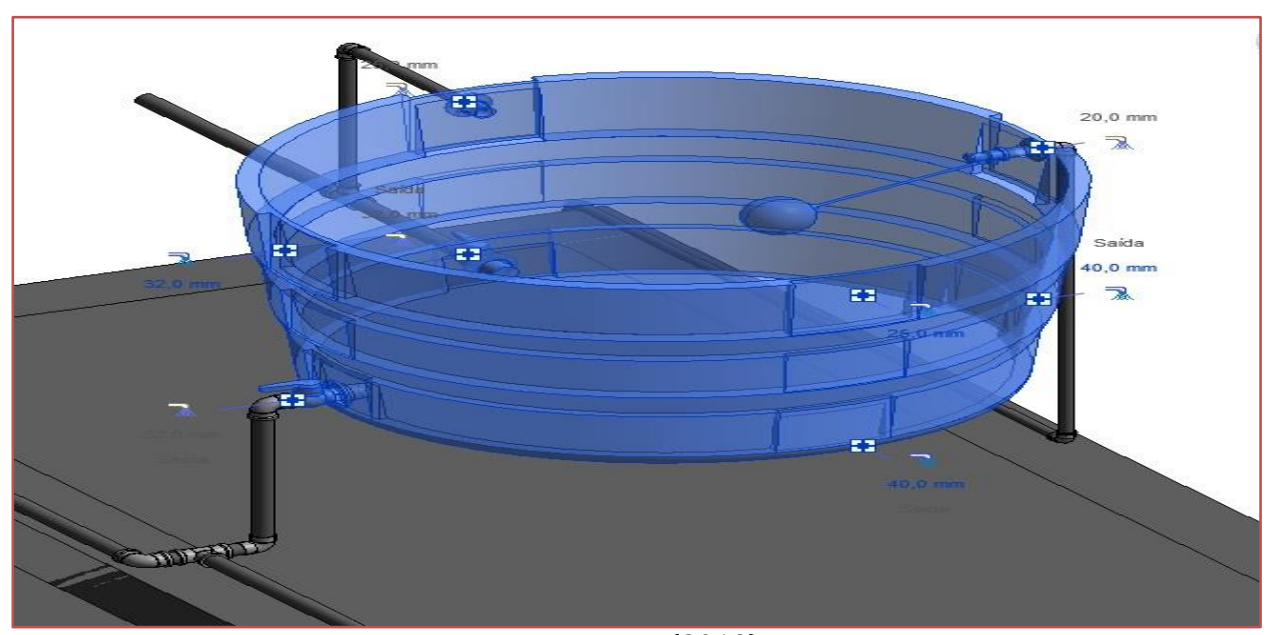

Fonte: autor (2019).

O projeto sanitário, aqui exposto na (Figura 17), não foi pensado para se conectar com a rede de esgoto municipal, em vez disso utilizou-se fossa circular e sumidouro. 
Figura 17: Projeto sanitário

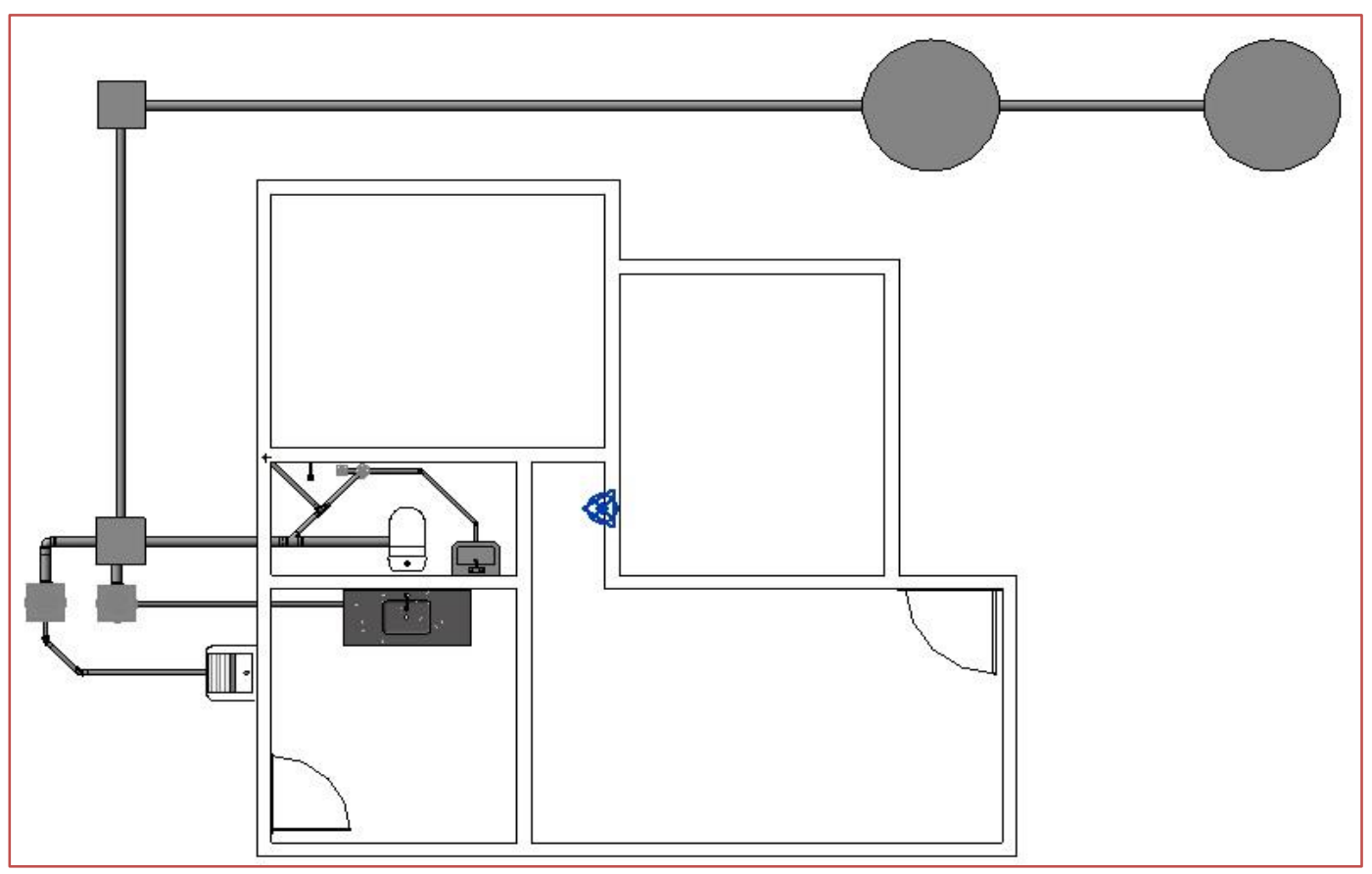

Fonte: autor (2019).

No detalhamento do projeto sanitário, embora não dimensionado, apresenta todas as peças convencionais como caixa de gordura, caixa de inspeção, caixa de passagem e no banheiro ralo quadrado e caixa sifonada (Figura 18).

Figura 18: Detalhe do projeto sanitário compatível com LDO 200.

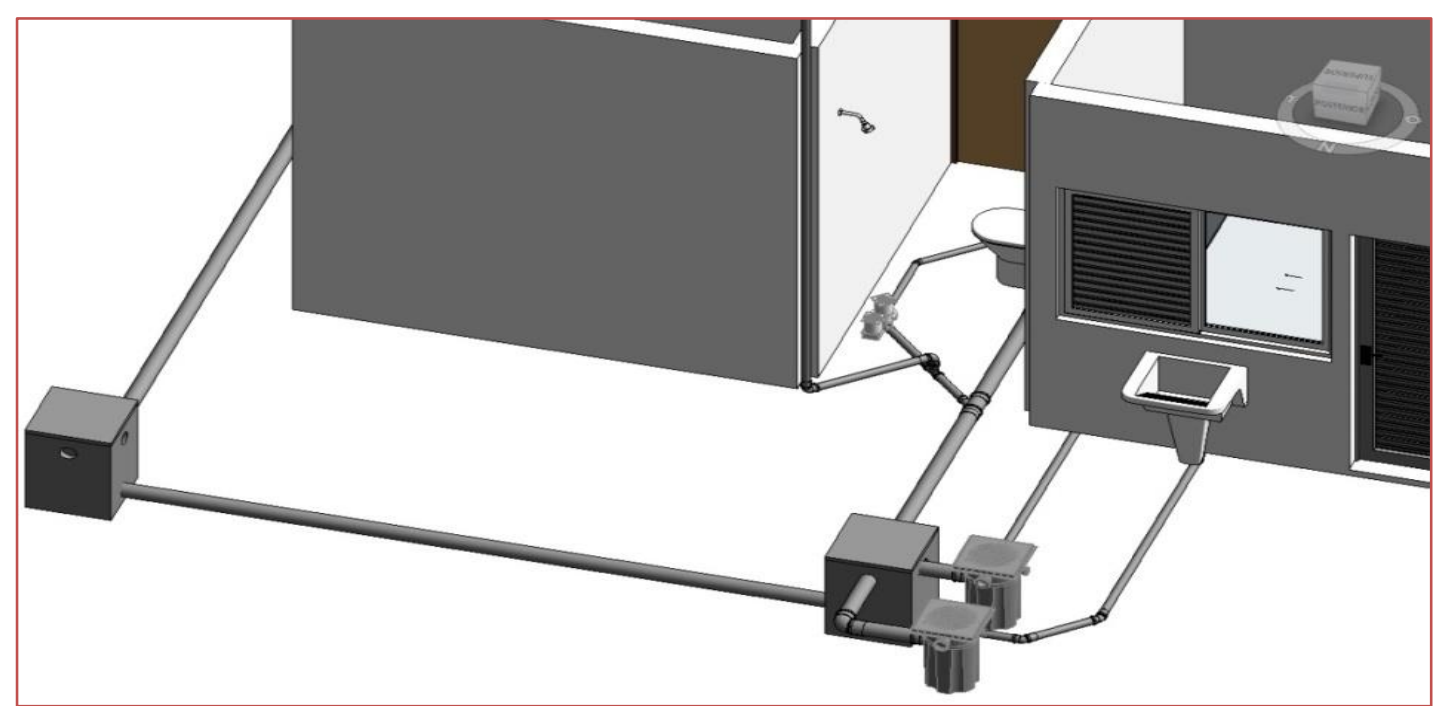

Fonte: autor (2019).

\section{CONSIDERAÇÕES FINAIS}

Ao longo do presente trabalho buscou-se demostrar a utilidade e eficiência das ferramentas BIM. Pode-se considerar bastante exitosa esta experiência, levando em conta que a modelagem BIM requer obrigatoriamente a interação de diversos profissionais especializados em cada tipo de projeto 
desenvolvido. Fato esse que foi superado adotando uma modelagem arquitetônica 3D mais simples para que os projetos complementares também exigissem menor esforço na concepção de cada um deles.

A utilização do software Revit 2018 foi possível graças à política de divulgação da Autodesk, que fornece licenças originais gratuitamente para estudantes, da qual utilizamos virtuosamente. Já a escolha do Tekla BIMsight para compatibilizar os projetos deu-se pela excelente interoperabilidade entre os softwares, visto que a leitura dos arquivos IFC gerados pelo Revit apresentam pequena perda de detalhes dos projetos quando abertos no Tekla BIMsight, possibilitando uma compatibilização mais eficiente. Sem contar com a possibilidade de utilizar um software original com licença aberta.

A compatibilização dos projetos, utilizando software, detectou os dois conflitos inseridos de forma proposital neste projeto e ainda encontrou outros 52 conflitos. Notabilizou-se mais conflitos que o esperado, vez que, a quantidade de 54 tipos de conflitos entre todos os projetos é um número significativo, ainda mais levando em conta que os projetos foram elaborados por um único profissional.

Pelo exposto, verifica-se a necessidade de mais tempo de estudo e detalhamento nos projetos, principalmente, em se tratando de construções que venham a ser executada.

Por fim, foi apresentada uma vasta revisão bibliográfica que corrobora com a intenção deste autor em mostrar a tendência irreversível de utilização do BIM para melhorar a gestão de projetos e tornar o setor da construção civil mais competitivo, fazendo uso das melhores e mais modernas práticas construtivas.

\section{REFERÊNCIAS}

[1] ASSOCIAÇÃO BRASILEIRA DE NORMAS TÉCNICAS. NBR 5410: Instalações elétricas de baixa tensão. 2 ed. Rio de Janeiro: ABNT, 2008. 209 p.

[2] ASSOCIAÇÃO BRASILEIRA DE NORMAS TÉCNICAS. NBR 5626: Instalação predial de água fria. Rio de Janeiro: ABNT, 1998. $41 \mathrm{p}$.

[3] ASSOCIAÇÃO BRASILEIRA DE NORMAS TÉCNICAS. NBR 6118: Projeto de estruturas de concreto procedimentos. 1 ed. Rio de Janeiro: ABNT, 2004. 221 p.

[4] ASSOCIAÇÃO BRASILEIRA DE NORMAS TÉCNICAS. NBR 6492: Representação de projetos de arquitetura. Rio de Janeiro: ABNT, 1994. $27 \mathrm{p}$.

[5] ASSOCIAÇÃO BRASILEIRA DE NORMAS TÉCNICAS. NBR 8160: Sistemas prediais de esgoto sanitário - Projeto e Execução. Rio de Janeiro: ABNT, 1999. 74 p.

[6] INSTITUTI BRASILEIRO DE DESENVOLVIMENTO DA ARQUITETURA - FÓRUM DA CONSTRUÇÃO (Brasil)

(Org.). 0 que é Patologia das Construções? 2019. Disponível em:

<http://www.forumdaconstrucao.com.br/conteudo.php?a=17\&Cod=1620>. Acesso em: 02 set. 2019.

[7] MOTA, Paula; RUSCHEL, Regina. Identificação do conhecimento acadêmico de BIM integrado ao gerenciamento de facilities. Entac, São Paulo, p.16-28, 21 set. 2016. 


\section{Capítulo 5}

Caracterização geotécnica de solo com vistas à aplicação em camada de base de pavimentos da cidade de Aracaju/SE

\section{Mayara Sales Sobral Freitas \\ Victor Manuel de Queiroz Lourenço}

Resumo: No Brasil, o transporte terrestre é o mais utilizado, principalmente para o deslocamento de pessoas e transporte de cargas. Por outro lado, as rodovias apresentam condições precárias e pouco investimento de manutenção, devido ao mal emprego de materiais em diferentes camadas de pavimentação. Diante disso, esta pesquisa tem a finalidade de caracterizar e avaliar o comportamento geotécnico dos solos, com vistas à sua utilização em camada de pavimentos enfatizando a caracterização e classificação de solos. Para isso, realizou-se ensaios laboratoriais, tais como, granulometria, limites de Atterberg, compactação e CBR. Os resultados de granulometria e limite de plasticidade identificaram o comportamento solo como material de camada de base em pavimentos, bem como os ensaios para classifica-los. Os resultados obtidos nos ensaios foram considerados satisfatórios, atendendo as especificações das normas para pavimentação.

Palavras-chave: Pavimentação. Caracterização. Classificação. 


\section{INTRODUÇÃO}

Os solos são materiais abundantes na natureza e desse modo, são utilizados como material de construção em diferentes ramos da engenharia. 0 uso do solo como material remete ao homem pré-histórico e a sua evolução, sua necessidade de deslocamento e de criar vias transitáveis, proporcionando crescimento e o desenvolvimento de estradas. No Brasil, o transporte terrestre é o modal mais utilizado no deslocamento de pessoas e de cargas.

De acordo com estudos da Confederação Nacional do Transporte - CNT, relacionados a infraestrutura rodoviária, a maioria dos acidentes acontecem devido as características dos pavimentos, os quais apresentam condições insatisfatórias e conferem insegurança para a sociedade, em consonância com baixos investimentos para infraestrutura e falta de manutenção.

Diante desse cenário, faz-se necessário conhecer e entender as características do solo, seu comportamento e os parâmetros para aplicação de acordo com sua utilização e solicitações. Essas propriedades são determinadas por meio de ensaios realizados em laboratório, que fornecem resultados importantes de identificação e classificação do solo.

O objetivo desta pesquisa é a caracterização geotécnica de um solo e da possível aplicação como camada de pavimento. Para isso foram estudados e analisados o comportamento do material por intermédio de ensaios laboratoriais, com o intuito de se obter resultados compatíveis com as normas.

\section{METODOLOGIA}

Localizado na região nordeste e, em extensão territorial, considerado o menor estado do Brasil, Sergipe limita-se ao norte com o estado de Alagoas, ao sul com o estado da Bahia e ao leste com o Oceano Atlântico. Possui área territorial de 21.926,908 $\mathrm{Km}^{2}$ dividido em 75 munícipios, 2.068.017 habitantes e densidade demográfica de 94,36 hab./km (IBGE, 2010).

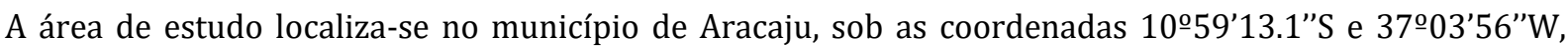
Bairro Aeroporto. 0 acesso ao local se dá pela Avenida Senador Júlio César Leite e pela Rua Cândido Inácio (Figura1).

Figura 1: Mapa do Brasil com localização do estado de Sergipe e município de Aracaju

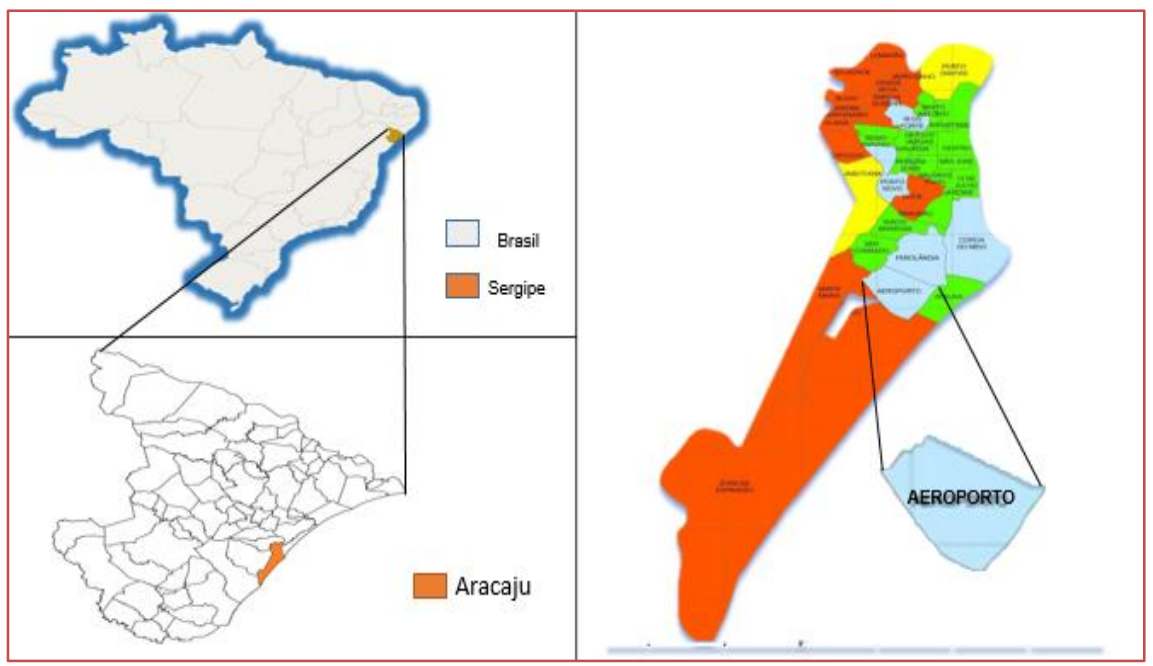

Fonte: Google Maps e Plano diretor de Aracaju.

O início do estudo relacionado ao tema da pesquisa deu-se mediante prévia pesquisa bibliográfica referente a área de estudo. Esta pesquisa foi direcionada para caracterização geotécnica de um solo, sendo abordado suas principais características e particularidades das propriedades para sua classificação.

O método desta pesquisa pode ser classificado como pesquisa de campo, pois foi coletada a amostra de solo e realizado ensaios em laboratório com a aplicação das normas para caracterizar o método escolhido. 
Quanto à forma de abordagem, pode ser classificada como qualitativa, visto que, os resultados obtidos foram analisados e interpretados.

Com o objetivo de avaliar um material utilizado em pavimentação, especificamente a camada de base, uma amostra deformada foi coletada em uma obra do sistema de macrodrenagem e pavimentação da cidade, antes e o durante da obra (Figura 2) (Figura 3).

Figura 2: Imagem aérea do local de estudo antes da realização da obra (a) e material de base (b)

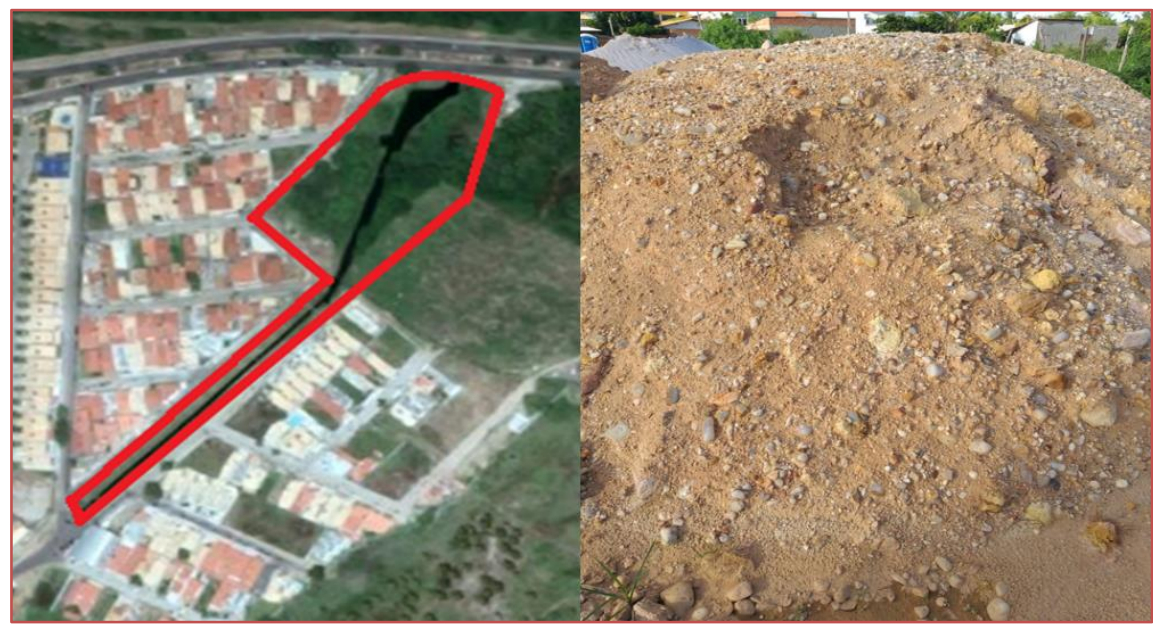

Figura 3: Imagem atualizada do local Fonte: Acervo pessoal, 2019.

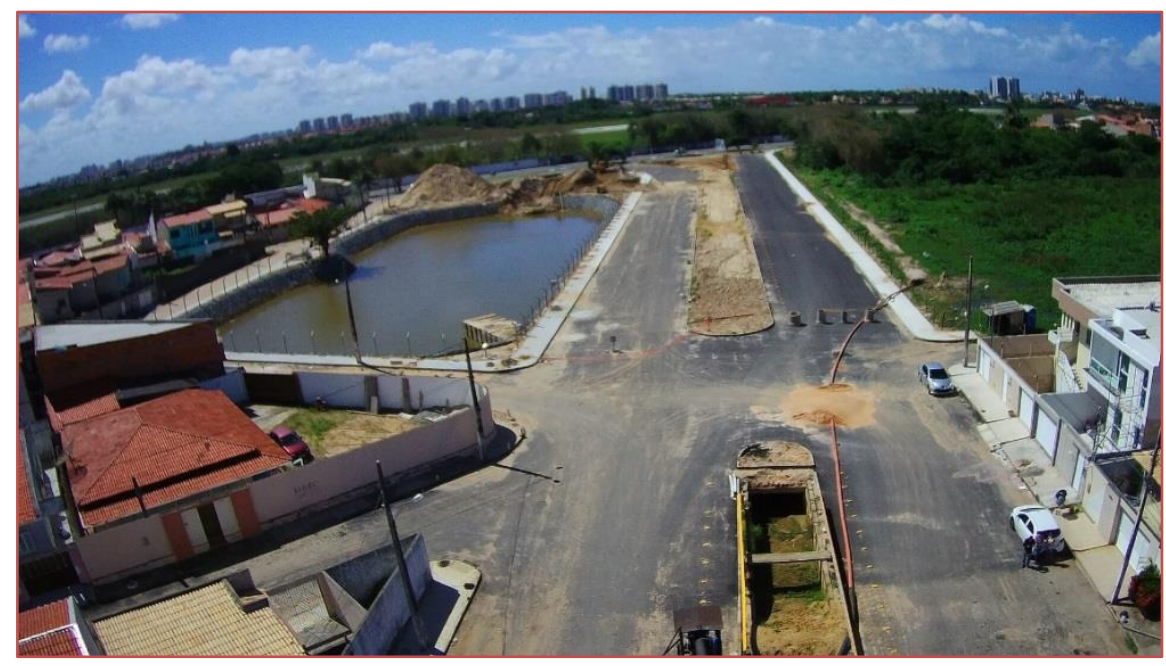

Os ensaios de caracterização foram realizados no Laboratório da Faculdade Pio Décimo Campus Jabotiana e no Laboratório de Geotecnia e Pavimentação da Universidade Federal de Sergipe, entre os dias 27 de abril a 31 de maio de 2019.

Os ensaios geotécnicos de caracterização e classificação das amostras que foram coletadas na área de estudo, foram realizados no laboratório seguindo as determinações das normas da ABNT e do DNIT, mostradas a seguir:

- Preparação para ensaios de Compactação e ensaios de Caracterização ABNT (NBR 6457,1986);

- Grãos de pedregulho retidos na peneira de 4,8 mm - Determinação da massa específica, massa específica aparente e da absorção de água ABNT (NBR 6458,1984);

- $\quad$ Análise Granulométrica de Solos ABNT (NBR 7181, 1984); 
- $\quad$ Limite de Plasticidade ABNT (NBR 7180, 1984)

- Compactação DNER (1994, ME 129/94).

- Índice de Suporte Califórnia DNER (1994, ME 049/94)

No laboratório da Faculdade Pio Décimo as amostras de solo coletada foram submetidas à secagem, destorroadas, e posteriormente, homogeneizadas. Em seguida, foram armazenadas em sacos plásticos para serem realizados os ensaios (Figura 4).

Figura 4: Preparação da amostra para ensaios
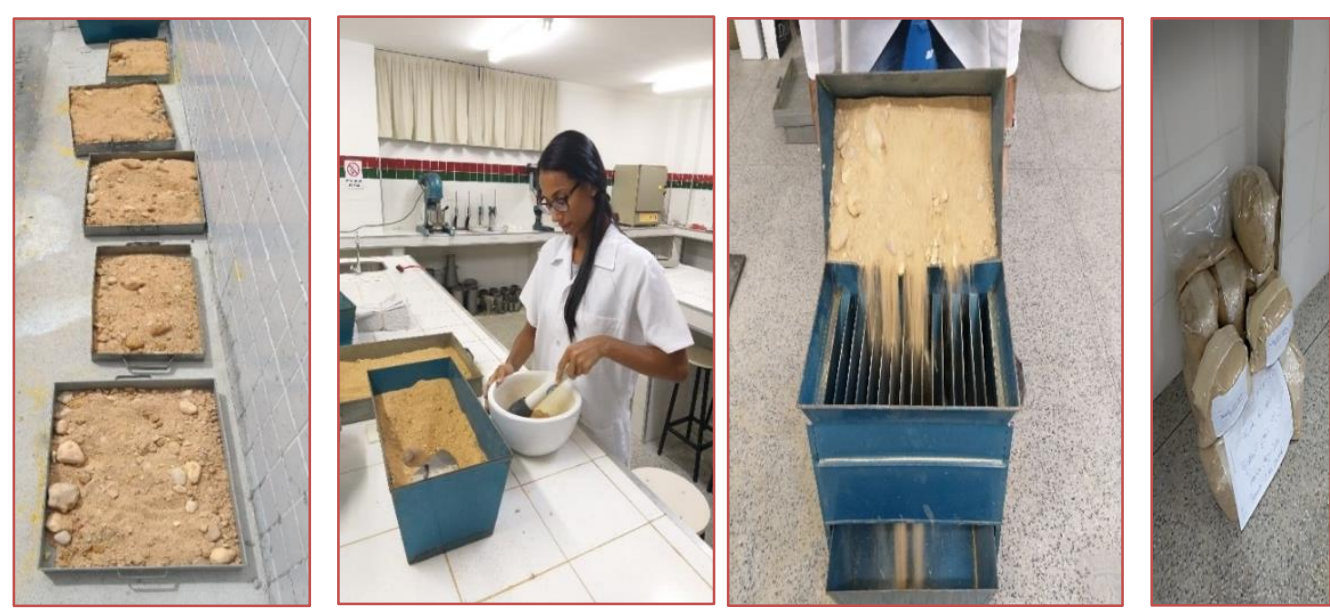

Fonte: Acervo pessoal, 2019

Para o ensaio de análise granulométrica foi utilizada balança digital, estufa, aparelho de dispersão, proveta de vidro, densímetro de bulbo, termômetro, cronômetro digital e peneiras de 50;38; 25; 19; 9,5; 4,8; 2,0; 1,$2 ; 0,6 ; 0,42 ; 0,30 ; 0,15$ e $0,075 \mathrm{~mm}$.

Após a preparação das amostras segundo a NBR 6457, iniciou a análise granulométrica por peneiramento grosso. Em seguida, foram separadas duas amostras, passadas no almofariz para desmanchar possíveis torrões e posterior determinação das massas. Logo após, esses materiais foram passados na peneira № 10 e o percentual retido foi lavado e seco em estufa por 24 horas.

Do material que passou na peneira $2,0 \mathrm{~mm}$, foram tomados cerca de $150 \mathrm{~g}$ para três determinações da umidade, utilizadas nas equações para obter a curva granulométrica.

Foram realizados dois ensaios de sedimentação, um para cada amostra, separando $120 \mathrm{~g}$ de material que passou na peneira № 10. Para a sedimentação o solo foi colocado em um béquer de $250 \mathrm{ml}$ e colocado 125 $\mathrm{ml}$ de defloculante e uma solução de hexametafosfato de sódio com a concentração de $45,7 \mathrm{~g} / \mathrm{cm}^{3}$. 0 béquer foi agitado até que todo material ficasse imerso e posto em repouso por no mínimo 12 horas (Figura 5.1).

Depois de transcorrido 12 horas, as amostras foram colocadas no copo de dispersão, onde foi adicionada água e posteriormente, o aparelho dispersor foi acionado no decorrer de 15 minutos (Figura 5.2), em seguida o material dispersado foi transferido para a proveta e completado com água destilada até a linha de referência de $1000 \mathrm{~cm}^{3}$ (Figura 5.3).

Logo após, a proveta foi agitada em movimentos de rotação no decorrer de 1 minuto (Figura 5.4), em seguida, foi colocada sobre a bancada e o horário do início da sedimentação foi anotado (Figura 5.5). 0 densímetro foi mergulhado cautelosamente na dispersão para realizar as leituras referentes aos tempos de 0,5, 1 e 2 minutos, sendo essas três leituras iniciais repetidas uma vez (Figura 5.6). As leituras conseguintes a 4, 8, 15 e 30 minutos, 1, 2, 4, 8 e 24 horas, a cada leitura a temperatura foi aferida (Figura 5.7). Após a última leitura o material na proveta foi vertido na peneira de №200, sem deixar nenhum resquício de solo que estava aderido nas paredes da proveta, e lavado a baixa pressão (Figura 5.8). 
0 material retido na peneira de $0,075 \mathrm{~mm}$, foi colocado para secar em estufa no período de 24 horas e em seguida foi colocado para peneirar com o auxílio do agitador mecânico, passando pelas peneiras de 1, 2, $0,6,0,42,0,30,0,15$ e $0,075 \mathrm{~mm}$. As frações retidas em cada peneira foram pesadas e suas massas anotadas.

Figura 5: Processo de sedimentação

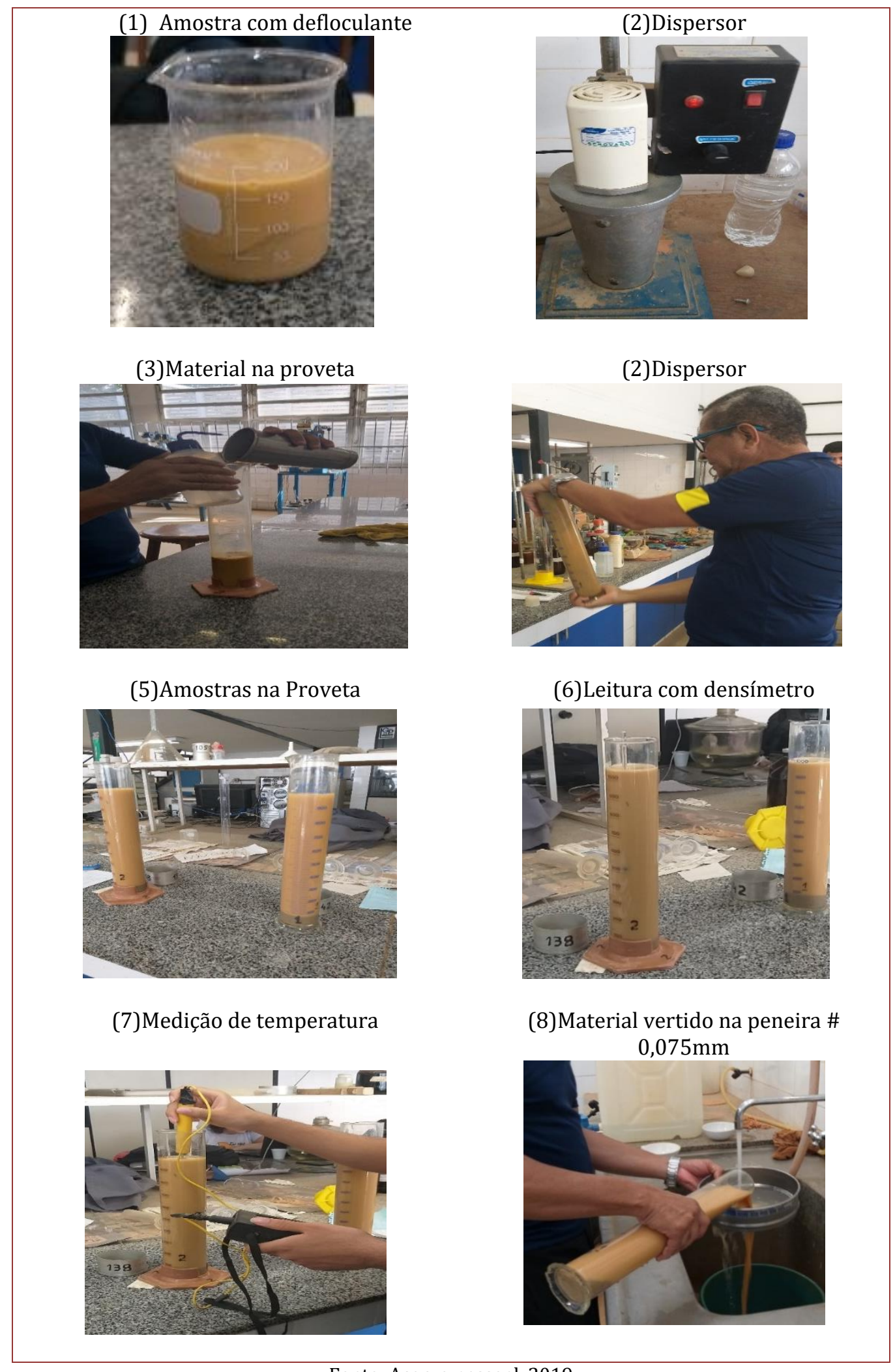

Fonte: Acervo pessoal, 2019 
Para o ensaio de determinação do limite de plasticidade seguiu-se a norma da ABNT NBR 7180, sendo realizado dois ensaios.

As amostras preparadas de acordo com a NBR 6457, foram separadas $100 \mathrm{~g}$ de cada. Foi utilizado para o ensaio, uma balança, uma placa de vidro de superfície esmerilhada, um gabarito cilíndrico com $3 \mathrm{~mm}$ de diâmetro e $100 \mathrm{~mm}$ de comprimento, uma cápsula de porcelana e uma espátula de lâmina flexível.

Após a pesagem, o solo foi depositado na cápsula de porcelana, adicionando água destilada em pequenas quantidades, misturando com o auxílio da espátula, de forma que obtivesse uma mistura homogênea. Uma pequena quantidade da amostra foi separada e sobreposta na placa de vidro para ser moldada. A amostra se fragmentou, o procedimento se repetiu e adicionou mais água destilada. 0 solo esfarelou ao ser moldado, caracterizando o solo (Figura 6).

Figura 6: Amostra de solo

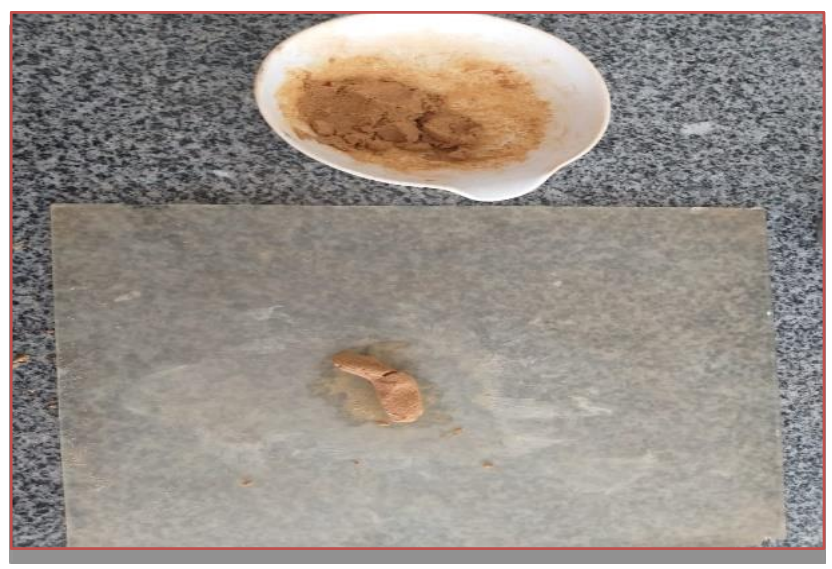

Fonte: Acervo pessoal, 2019.

Para determinar o peso específico das partículas que constituem o solo, realizou-se o ensaio de densidade real, utilizando o método do picnômetro.

Os ensaios da massa específica real dos grãos do solo seguiram o prescrito pelo DNER - ME 093/94. A amostra de solo seco, 10g, foi separada conforme o método de preparação de amostras.

Pesou-se o picnômetro vazio, que estava seco e limpo. Posteriormente a amostra foi colocada no picnômetro e seu peso foi anotado (Figura 7.1). Adicionou-se água destilada no picnômetro até cobrir o material, em seguida, ele foi para a bomba de vácuo e ficou durante 15 minutos, agitando-o de modo que todo ar existente entre as partículas do solo fosse expulso (Figura 7.2).

0 volume do picnômetro foi complementado com água destilada (Figura 7.3). Todo o material que continha no picnômetro foi retirado, lavado e preenchido com água destilada (Figura 7.4). Colocou a rolha e pesou o conjunto picnômetro mais água. 
Figura 7: Método do picnómetro

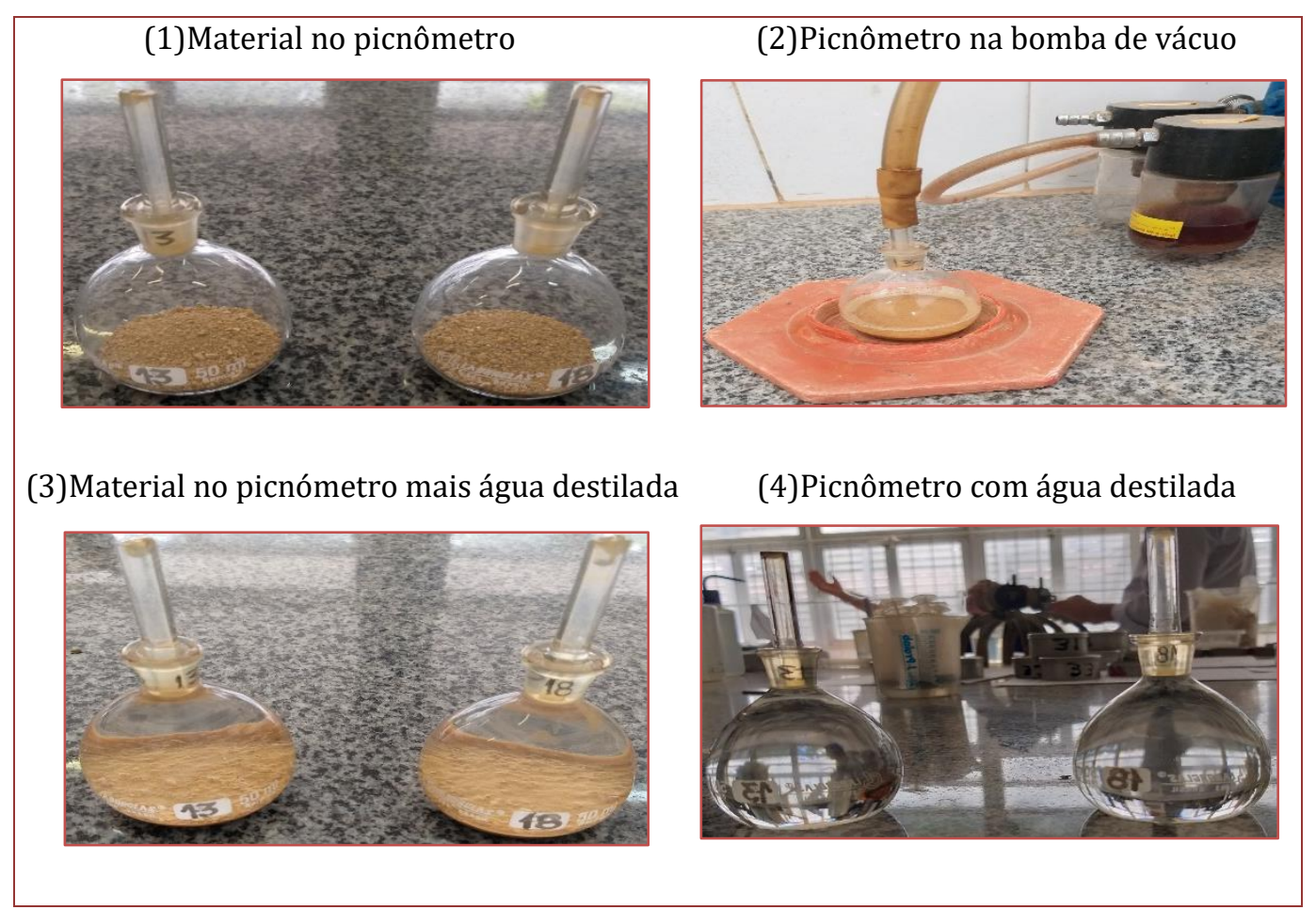

Fonte: Acervo pessoal, 2019.

O ensaio de compactação foi realizado segundo as normas do DNER - ME 129/94. No ensaio foram determinadas o peso específico seco máximo e o teor de umidade ótimo, para as duas amostras de solo analisadas. A energia de compactação utilizada corresponde a do Proctor intermediário, sendo 5 camadas e 26 golpes por camada.

Foram realizados dois ensaios de compactação, e o peso da amostra de solo de ambos foi de $6000 \mathrm{~g}$. Os solos foram compactados em um molde com um volume de $2,08 \mathrm{dm}^{3}$. Para a realização do ensaio adicionou-se a água inicial e homogeneízou-se a amostra. A amostra foi colocada no cilindro, com o cilindro complementar ajustado, fixado na base metálica e com o disco espaçador. 0 material foi compactado no molde em camadas iguais, os golpes foram distribuídos em toda camada uniformemente.

A Figura 8(1), mostra a última camada compactada, já com o cilindro complementar removido e execução do arrasamento com o auxílio da régua de aço biselada e a Figura 8(2) mostra o corpo de prova sendo removido do cilindro.

Figura 8: Ensaio de compactação

(1)Arrasamento da última camada

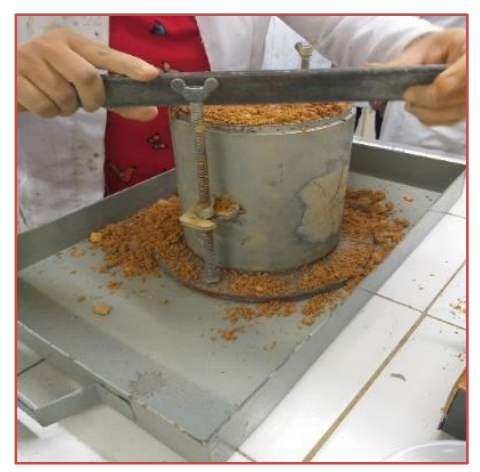

(2)Corpo de prova

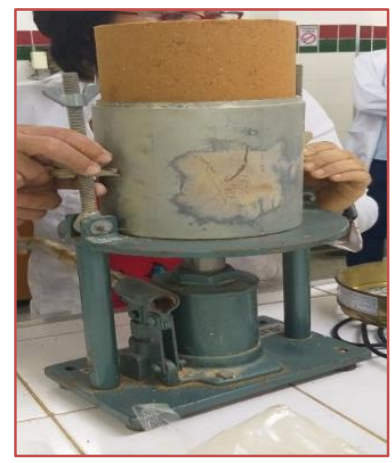


Realizou-se os ensaios para traçar a curva de compactação, os pontos devem definir a umidade ótima e a densidade seca da curva. Nos dois ensaios de compactação foram repetidos os mesmos processos.

Para o ensaio de Índice de Suporte Califórnia (CBR), a moldagem do corpo de prova correspondeu a energia intermediária, seguindo a energia de compactação. 0 ensaio de CBR é executado de acordo com o método adotado no Brasil (DNER - ME 049/94), citado anteriormente.

Os corpos de prova ficaram imersos por quatro dias, e suas leituras foram anotadas durante o período, sendo efetuadas no extensômetro de 24 em 24 horas (Figura 9).

Figura 9: Submersão dos corpos de prova

E01

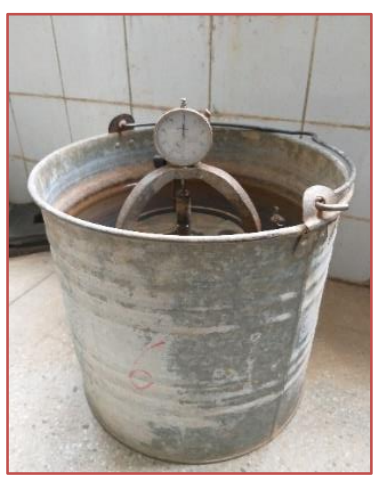

E02

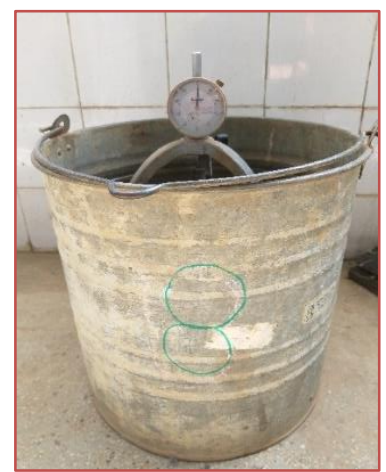

Fonte: Acervo pessoal, 2019.

Após o período de 96 horas, o molde com o corpo de prova foi retirado da imersão e deixado drenar por 15 minutos. Foi pesado o conjunto, molde e amostra úmida compactada, antes e depois da imersão. Posteriormente, foram anotados, de acordo com o tempo, as leituras dos valores de penetração do pistão no solo. Com esses valores é possível traçar a curva pressão versus penetração do pistão.

Para a análise de dados foi realizado ensaios em laboratório para obter resultados confiáveis e fidedignos. Com os valores obtidos através dos ensaios, foi possível a construção de tabelas e gráficos, utilizando um software da Microsoft, o Excel, através dele é possível interpretar os dados para caracterizar e classificar o solo.

\section{RESULTADOS E DISCUSSÃO}

Nesse capítulo são apresentados e argumentados os resultados referentes a esta pesquisa, obtidos através dos ensaios de caracterização e classificação.

\subsection{ENSAIOS DE CARACTERIZAÇÃO GEOTÉCNICA}

A distribuição granulométrica dos agregados é uma de suas principais propriedades e tem influência no desempenho dos revestimentos asfálticos (BERNUCCI et al, 2006).

Os resultados dos ensaios da análise granulométrica do solo puro, obtidos no Laboratório de Geotecnia e Pavimentação da UFS, estão representados por meio das curvas granulométricas dois ensaios realizados (Figura 10) (Figura 11). 
Figura 10: Curva granulométrica do Ensaio 01

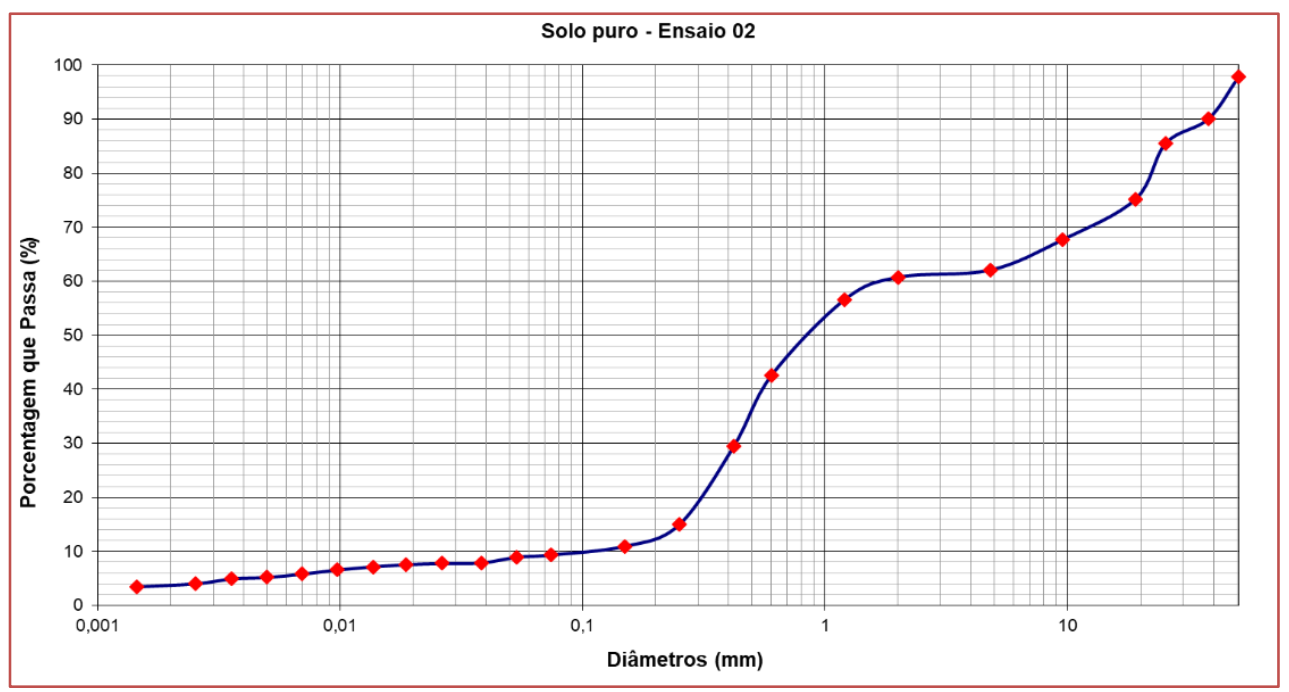

Fonte: Acervo pessoal, 2019.

Figura 11: Curva granulométrica do Ensaio 02

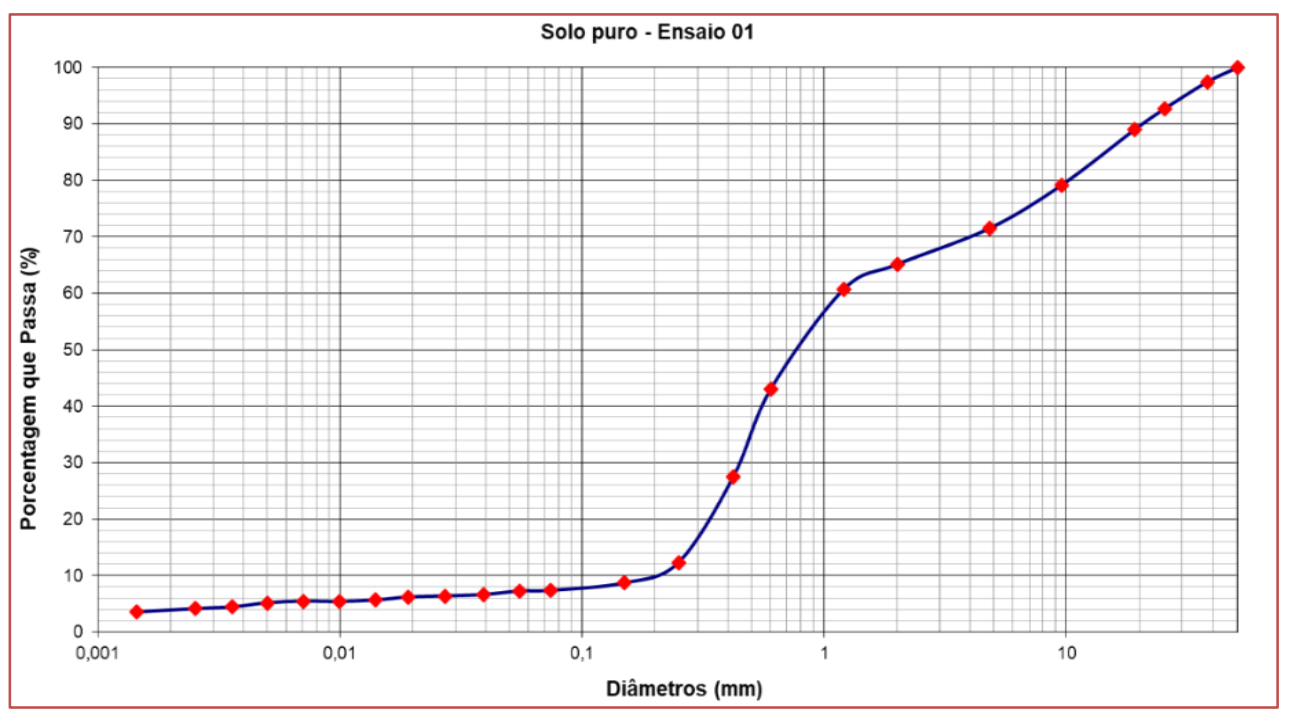

Fonte: Acervo pessoal, 2019.

Através das Figuras 10 e 11 observa-se que a curva granulométrica em ambas é descontínua, ou seja, o material não apresenta uniformidade nas frações. Trata-se de solo arenoso, bem homogêneo e com aproximadamente de $10 \%$ de finos.

Esse resultado é satisfatório, a presença de frações finas em materiais granulares, representado pela porcentagem que passa na peneira №200, usualmente é limitada para o uso como materiais em obras de pavimentação.

Bernucci et al (2006) afirmam que essa limitação de finos, ocorre pela sua propriedade de plasticidade, na maioria das vezes reduzem a permeabilidade dos materiais e sua rigidez. Além disso, apresenta variação de volume devido sua expansão em presença de água, provocando a redução da sua resistência.

Para melhor precisão quanto aos valores das frações granulométricas dos ensaios, a Tabela 1 apresenta as dimensões do solo divididas em grupos de acordo com o DNIT (2006) e suas proporções relativas ao peso total da amostra. 
Tabela 1 - Frações granulométricas das amostras por grupo

\begin{tabular}{c|c|c|c|c}
\multicolumn{2}{c}{ Ensaios } & \multicolumn{2}{c}{ Pedregulho } & \multicolumn{2}{c}{ Areia } & \multicolumn{2}{c}{ Silte } & $\begin{array}{c}\text { Argila } \\
<0,005 \mathrm{~mm}\end{array}$ \\
\hline E-01(\%) & $76,2 \mathrm{~mm} \mathrm{a} 2,0 \mathrm{~m}$ & $2,0 \mathrm{~mm}$ a 0,075 mm & $0,075 \mathrm{a} 0,005 \mathrm{~mm}$ & 5,17 \\
\hline E-02(\%) & 34,86 & 57,77 & 2,20 & 5,19 \\
\hline
\end{tabular}

Fonte: Acervo pessoal, 2019.

A Tabela 2 apresenta, respectivamente, os resultados dos ensaios por peneiramento e sedimentação e a correlação entre a Tabela 1, referente a faixa granulométrica exigida pelo DNIT.

Tabela 2 - Resultado da granulometria e correlação da faixa classificatória.

\begin{tabular}{c|c|c|c}
\hline \multirow{2}{*}{ Tamanho da peneira } & \multicolumn{2}{c}{ Porcentagem que passa (\%) } & $\begin{array}{c}\text { Faixa D } \\
\text { (Classificação - } \\
\text { DNIT) }\end{array}$ \\
\cline { 2 - 4 } 2" & E-01 & E-02 & -- \\
\hline 1" & 100 & 97,86 & 100 \\
\hline 3/8" & 92,72 & 85,56 & $60-100$ \\
\hline №4 & 79,13 & 67,66 & $50-85$ \\
\hline №10 & 71,50 & 62,08 & $25-45$ \\
\hline №40 & 65,14 & 60,76 & $10-25$ \\
\hline №200 & 27,42 & 29,42 & \\
\hline & 7,37 & 9,34 & \\
\hline
\end{tabular}

Segundo o DNIT (2006), quando o material é submetido aos ensaios de caracterização, deve apresentar propriedades relativas ao indicado pela norma. Com a representação dos dados na Tabela 2 é possível identificar em qual faixa da norma, a composição granulométrica faz-se satisfatória, o material em questão, base granular, está enquadrado na Faixa D.

A Tabela 3, apresenta os valores da umidade higroscópica da amostra de solo, sendo realizado dois ensaios para determiná-lo.

Tabela 3 - Resultado do teor de umidade.

\begin{tabular}{|c|c|c|c|c|c|}
\hline \multicolumn{6}{|c|}{ TEOR DE UMIDADE } \\
\hline & Cápsula (g) & $\begin{array}{c}\text { Cáp. + Solo } \\
\text { úmido (g) }\end{array}$ & Cáp. + Solo úmido (g) & Umidade (\%) & $\begin{array}{c}\text { Média } \\
\text { Umidade (\%) }\end{array}$ \\
\hline \multirow{3}{*}{ E-01 } & 21,41 & 72,35 & 72,25 & 0,20 & \multirow{3}{*}{0,19} \\
\hline & 21,72 & 71,89 & 71,79 & 0,20 & \\
\hline & 21,41 & 71,79 & 71,70 & 0,18 & \\
\hline \multirow{3}{*}{ E-02 } & 21,81 & 72,18 & 72,06 & 0,24 & \multirow{3}{*}{0,21} \\
\hline & 21,78 & 72,23 & 72,17 & 0,12 & \\
\hline & 21,70 & 72,21 & 72,07 & 0,28 & \\
\hline \multicolumn{5}{|c|}{ Média do teor de umidade (\%) } & 0,19 \\
\hline
\end{tabular}

Fonte: Acervo pessoal, 2019.

Os ensaios dos limites de consistência têm influência do comportamento do solo, por ser um solo bastante arenoso e com poucos finos, não foi possível manuseá-lo sem que o mesmo não se desmanchasse. Sendo assim, não foi possível determinar os valores dos limites de consistência da amostra. 0 solo foi classificado como não plástico, ou seja, IP=LP.

Os valores da Tabela 4 ilustram o cálculo da densidade real do solo, que se refere ao peso específico dos grãos. 
Tabela 4 - Resultado do peso específico real dos grãos.

\begin{tabular}{|c|c|c|c|c|c|c|c|c|c|}
\hline Ensaio & P1 & P2 & P3 & P4 & $\begin{array}{l}\text { M.Esp. } \\
\text { Real }\end{array}$ & $\mathrm{T}^{\mathrm{o}} \mathrm{C}$ & K20 & D 20 & Média \\
\hline E-01 & 33,743 & 44,691 & 90,745 & 83,924 & 2,653 & 27,7 & 0,99809 & 2,648 & \multirow[t]{2}{*}{2,645} \\
\hline E-02 & 31,881 & 42,968 & 93,779 & 86,880 & 2,647 & 27,8 & 0,99806 & 2,642 & \\
\hline
\end{tabular}

Fonte: Acervo pessoal, 2019.

Descrição: P1 = Peso do picnômetro; P2 = Peso do picnomêtro + solo; P3 = Peso do picnomêtro + solo + água; P4 = Peso do picnomêtro + água; $\mathrm{T}^{\mathrm{o}} \mathrm{C}=$ Temperatura da água destilada.

Senço (2009) afirma que para uma camada de base de solo estabilizado ser construída, ela deve satisfazer determinados parâmetros, como: granulometria e limites de consistência, podendo ser estabilizada de forma natural ou artificial. Entretanto, ela deve atender as exigências normatizadas pelo DNIT (2006), apresentar o limite de liquidez máximo de $25 \%$ e ou índice de plasticidade máximo de $6 \%$, quantidade equivalente de areia maior que $30 \%$, e se enquadrar nas faixas granulométricas citadas anteriormente, que satisfaça as condições do CBR.

\subsection{ENSAIOS DE CLASSIFICAÇÃO DO SOLO}

As curvas de compactação do solo analisado são apresentadas com o objetivo de definir a umidade ótima do solo, associada ao seu peso específico aparente seco (Figura 12) (Figura 13).

Figura 12: Curva de compactação do primeiro ensaio

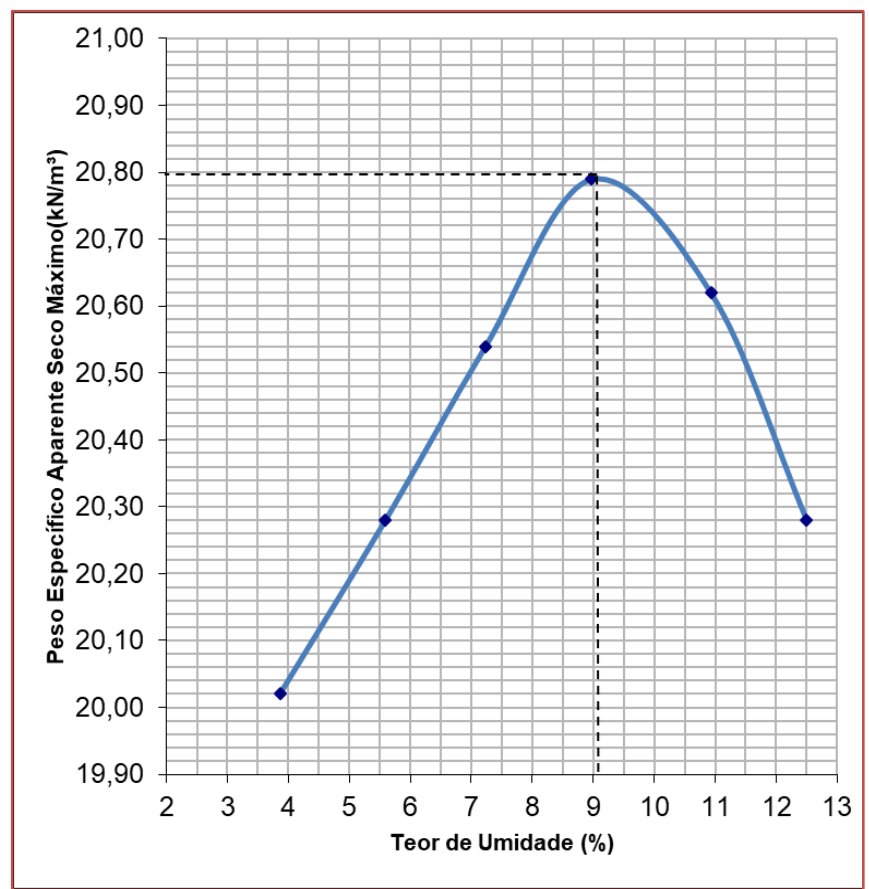

Curva de compactação E-01

Fonte: Acervo pessoal, 2019. 
Figura 13: Curva de compactação do segundo ensaio Curva de Compactação E-02

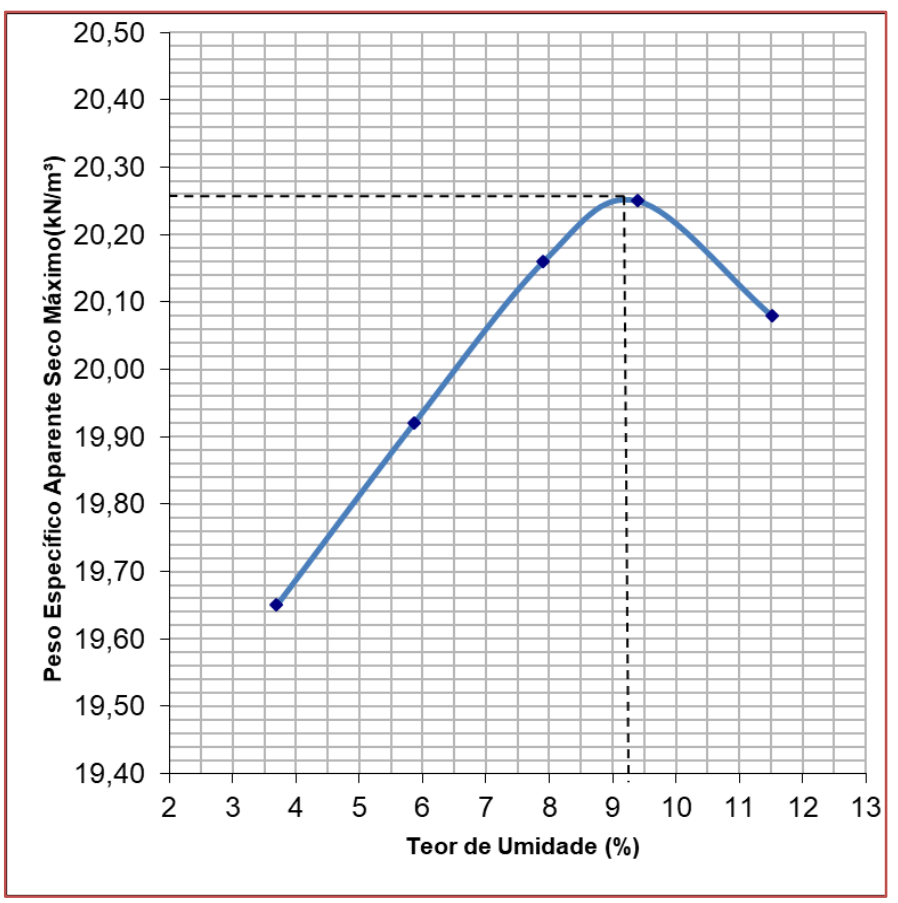

Fonte: Acervo pessoal, 2019.

Posterior a apresentação das curvas de compactação, segue os dados obtidos pelos ensaios (Tabelas 5) (Tabela 6).

Tabela 5 - Dados do primeiro ensaio de Compactação.

\begin{tabular}{|c|c|c|c|c|c|c|}
\hline \multicolumn{7}{|c|}{ ENSAIO 01} \\
\hline $\begin{array}{c}\text { Ensaio } \\
\text { № }\end{array}$ & $\begin{array}{c}\text { Amostra } \\
\text { Compactada (g) }\end{array}$ & $\begin{array}{l}\text { Cáps. + solo } \\
\text { úmido (g) }\end{array}$ & $\begin{array}{l}\text { Cáps. + solo } \\
\text { seco (g) }\end{array}$ & $\begin{array}{l}\text { Peso } \\
\text { cápsula } \\
\text { (g) }\end{array}$ & $\begin{array}{l}\% \text { de } \\
\text { água }\end{array}$ & $\begin{array}{l}\text { Densidade do } \\
\text { solo seco }\end{array}$ \\
\hline 1 & 4325 & 139,08 & 134,67 & 20,52 & 3,86 & 20,02 \\
\hline 2 & 4453 & 129,09 & 123,35 & 20,70 & 5,59 & 20,28 \\
\hline 3 & 4580 & 152,39 & 143,47 & 20,10 & 7,23 & 20,54 \\
\hline 4 & 4711 & 140,74 & 130,81 & 20,16 & 8,97 & 20,79 \\
\hline 5 & 4758 & 138,11 & 126,52 & 20,48 & 10,93 & 20,62 \\
\hline 6 & 4746 & 138,43 & 125,38 & 20,98 & 12,50 & 20,28 \\
\hline \multicolumn{5}{|c|}{ Umidade ótima de compactação } & \multicolumn{2}{|c|}{$9,10 \%$} \\
\hline \multicolumn{5}{|c|}{ Peso específico aparente seco máximo } & \multicolumn{2}{|c|}{$20,79 \mathrm{KN} / \mathrm{m}^{3}$} \\
\hline
\end{tabular}

Fonte: Acervo pessoal, 2019. 
Tabela 6 - Dados do segundo ensaio de Compactação

\begin{tabular}{|c|c|c|c|c|c|c|}
\hline \multicolumn{7}{|c|}{ ENSAIO 02} \\
\hline $\begin{array}{c}\text { Ensaio } \\
\text { № }\end{array}$ & $\begin{array}{c}\text { Amostra } \\
\text { Compactada (g) }\end{array}$ & $\begin{array}{l}\text { Cáps. + solo } \\
\text { úmido (g) }\end{array}$ & $\begin{array}{c}\text { Cáps. + solo } \\
\text { seco (g) }\end{array}$ & $\begin{array}{c}\text { Peso } \\
\text { cápsula } \\
\text { (g) }\end{array}$ & $\begin{array}{l}\% \text { de } \\
\text { água }\end{array}$ & $\begin{array}{l}\text { Densidade do } \\
\text { solo seco }\end{array}$ \\
\hline 1 & 4237 & 125,96 & 122,45 & 27,20 & 3,69 & 19,65 \\
\hline 2 & 4387 & 123,52 & 118,21 & 27,67 & 5,86 & 19,92 \\
\hline 3 & 4523 & 127,94 & 120,61 & 27,90 & 7,91 & 20,16 \\
\hline 4 & 4607 & 128,63 & 119,98 & 27,92 & 9,40 & 20,25 \\
\hline 5 & 4657 & 118,50 & 109,07 & 27,21 & 11,52 & 20,08 \\
\hline \multicolumn{5}{|c|}{ Umidade ótima de compactação } & \multicolumn{2}{|c|}{$9,20 \%$} \\
\hline \multicolumn{5}{|c|}{ Peso específico aparente seco máximo } & \multicolumn{2}{|c|}{$20,60 \mathrm{KN} / \mathrm{m}^{3}$} \\
\hline
\end{tabular}

Fonte: Acervo pessoal, 2019.

A curva de compactação do Proctor Intermediário do ensaio 01 (Figura 12) foi obtida utilizando os 6 pontos de umidades, sendo necessário realizar 6 ensaios para traçar a curva. Para a curva de compactação do ensaio 02 foi preciso 5 pontos para determinar a umidade ótima e o peso específico (Figura 13).

A compactação tem em vista o aspecto de acrescentar água para diminuir a resistência às deformações e aumentar o contato entre os grãos. A partir desse momento, reduz o índice de vazios e não existe a possibilidade de saída de ar. Ao evidenciar-se com um peso específico seco máximo, para uma energia aplicada, que conduz a uma umidade ótima, a compactação do solo é satisfatória (Pinto, 2006).

Os resultados do Índice de Suporte Califórnia (ISC) ou CBR (s) dos ensaios realizados com energia intermediária são mostrados pelo gráfico (Figuras 14) (Figura 15). Os gráficos representam também, os valores das pressões corrigidas, correspondentes as penetrações 0,1 e 0,2 de distância. Em seguida, a apresentação dos gráficos, segue os dados obtidos pelos ensaios (Tabelas 7) (Tabela 8).

Figura 14: Resultado CBR do ensaio 01.

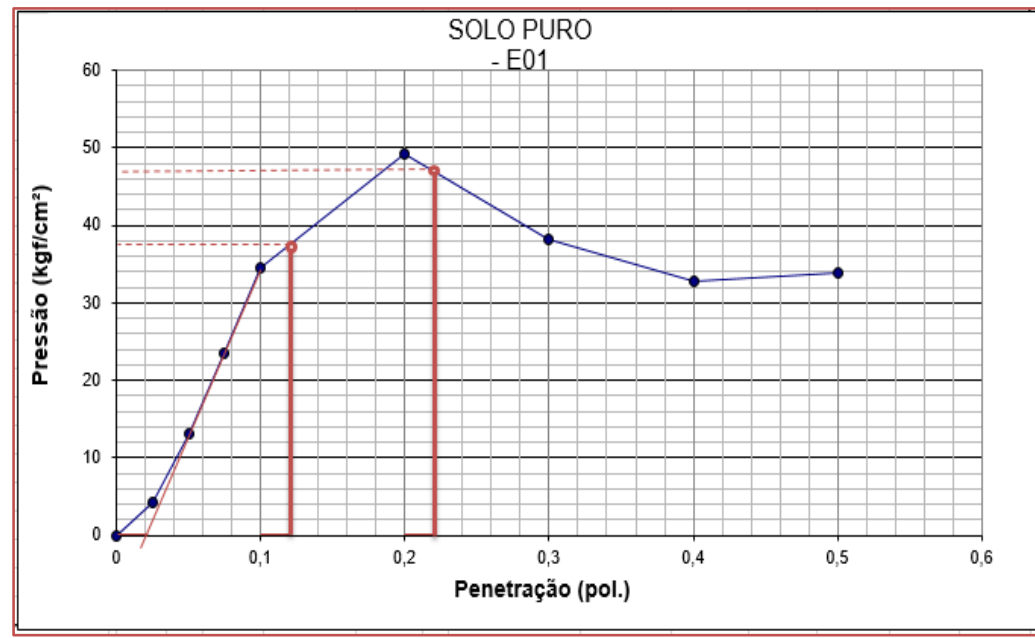

Fonte: Acervo pessoal, 2019. 
Figura 15: Resultado CBR do ensaio 02.

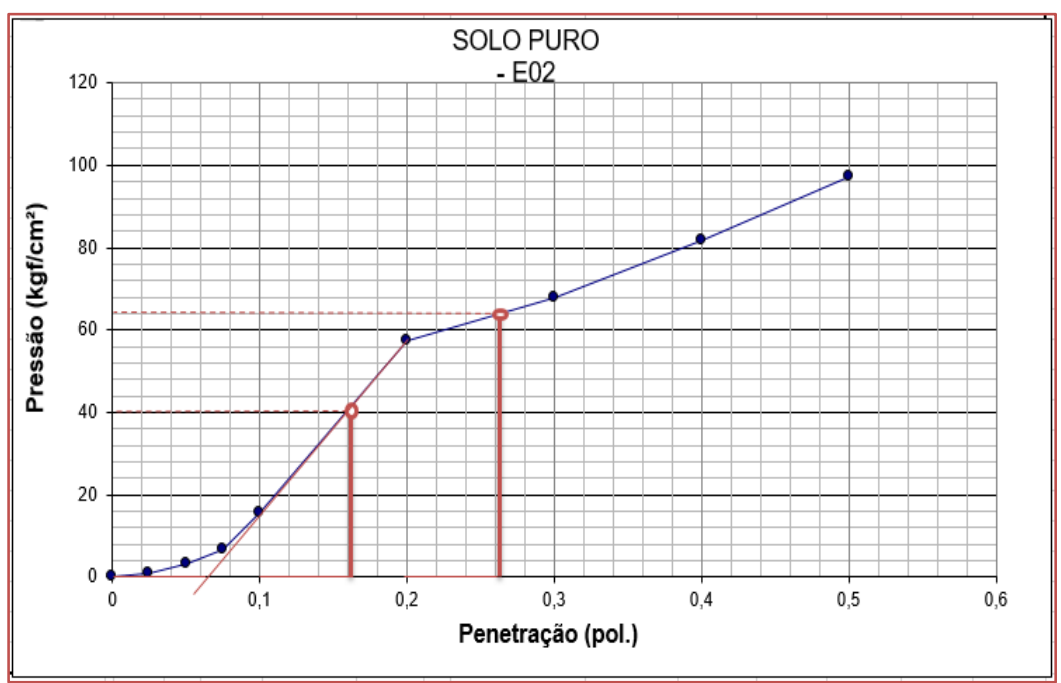

Fonte: Acervo pessoal, 2019.

Tabela 7 - Valores do ensaio de Determinação do I.S.C. 01

\begin{tabular}{|c|c|c|c|c|c|c|c|}
\hline \multirow{2}{*}{$\begin{array}{l}\text { Tempo } \\
\min \end{array}$} & \multicolumn{2}{|c|}{ Penetração } & \multirow{2}{*}{$\begin{array}{l}\text { Pressão } \\
\text { Padrão } \\
\left(\mathrm{kgf} / \mathrm{cm}^{2}\right)\end{array}$} & \multirow{2}{*}{$\begin{array}{c}\text { Leitura no } \\
\text { Extensômetro }\end{array}$} & \multicolumn{2}{|c|}{ Pressão (Kgf/cm²) } & \multirow{2}{*}{$\begin{array}{l}\text { I.S.C. } \\
(\%)\end{array}$} \\
\hline & $(\mathrm{mm})$ & (pol.) & & & Calculada & Corrigida & \\
\hline \multirow[t]{2}{*}{0,5} & 0,63 & 0,025 & 1,0 & 42 & 4,27 & & \\
\hline & 1,27 & 0,050 & --- & 129 & 13,10 & & \\
\hline 1,5 & 1,90 & 0,075 & --- & 231 & 23,47 & & \\
\hline 2,0 & 2,50 & 0,100 & 70,0 & 340 & 34,54 & 37,80 & 54,00 \\
\hline 4,0 & 5,08 & 0,200 & 105,0 & 484 & 49,17 & 47,00 & 44,76 \\
\hline 6,0 & 7,62 & 0,300 & 132,0 & 375 & 38,10 & & \\
\hline 8,0 & 10,16 & 0,400 & 161,0 & 322 & 32,71 & & \\
\hline 10,0 & 12,70 & 0,500 & 182,0 & 334 & 33,93 & & \\
\hline \multicolumn{6}{|c|}{ Umidade ótima } & \multicolumn{2}{|c|}{9,00} \\
\hline \multicolumn{6}{|c|}{ Densidade máx. } & \multicolumn{2}{|c|}{2085} \\
\hline \multicolumn{6}{|c|}{ \% de água absorvida } & \multicolumn{2}{|c|}{2,11} \\
\hline \multicolumn{6}{|c|}{ Expansão (\%) em 4 dias } & \multicolumn{2}{|c|}{0,01} \\
\hline
\end{tabular}

Fonte: Acervo pessoal, 2019.

Tabela 8 - Valores do ensaio de Determinação do I.S.C. 02

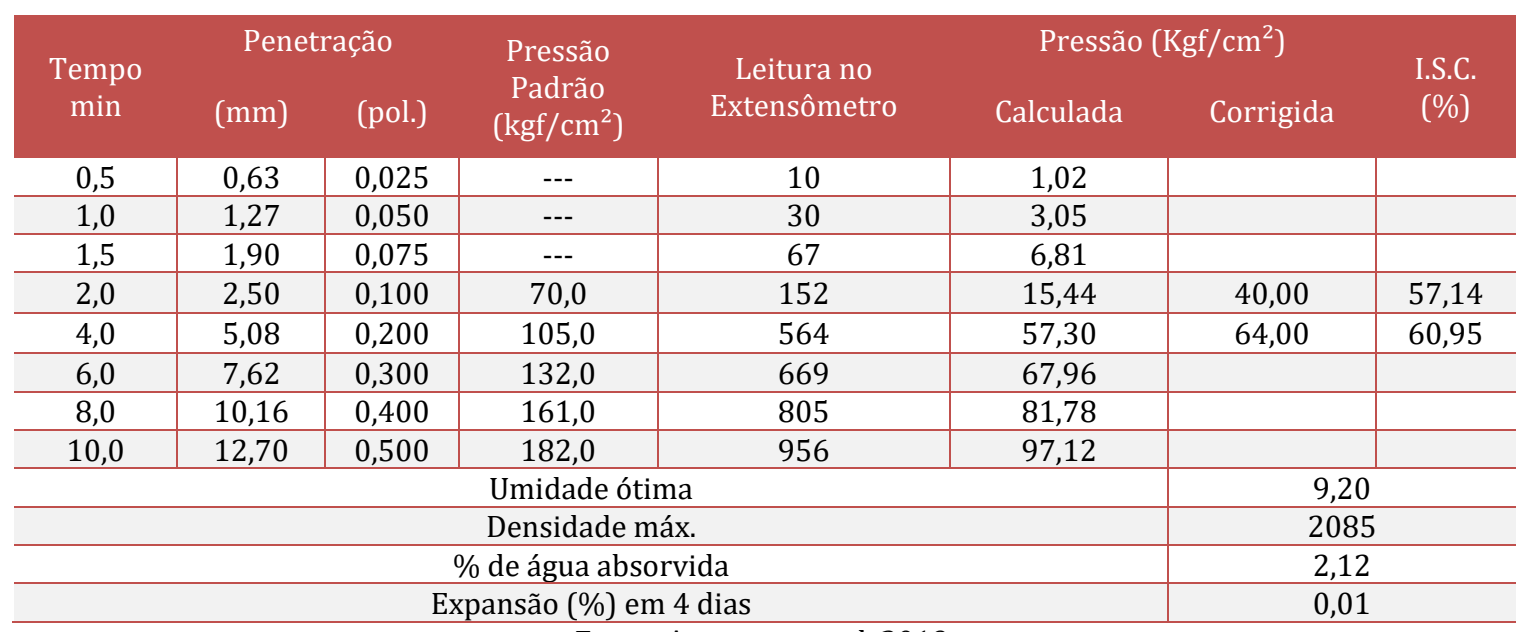

Fonte: Acervo pessoal, 2019. 
Os resultados finais, com a correção, ensaio 1: CBR =54\%; e o ensaio 2: CBR = 61\%, visto que, é adotado o maior valor encontrado. Já o valor da expansão foi 0,01\% em ambos ensaios.

\section{CONSIDERAÇÕES FINAIS}

A presente pesquisa analisou o comportamento do solo que vem sendo aplicado como camada base estabilizada granulometricamente no município de Aracaju, estado de Sergipe.

A fim de caracterizar o solo que será utilizado na infraestrutura urbana, os ensaios indicaram o comportamento do solo, apresentando granulometria enquadrada na Faixa D do DNIT e a determinação de material não plástico. Observou-se também, que quanto as condições do solo para a compactação, visando o melhor teor de umidade e a máxima resistência correspondente ao CBR, este apresentou valor aceitável para rodovias urbanas.

De acordo com os resultados obtidos nos ensaios realizados e análise dos dados, os resultados atenderam as exigências normatizadas pelo Departamento Nacional de Infraestrutura de Transportes (DNIT). Portanto, o material apresenta condições ideais para ser empregado em camada de pavimentação como base estabilizada granulometricamente.

\section{REFERÊNCIAS}

[1] ASSOCIAÇÃO BRASILEIRA DE NORMAS TÉCNICAS - ABNT. NBR 6457: Amostra de Solo - Preparação para ensaios de compactação e ensaios de caracterização - Método de ensaio. Rio de Janeiro, 1986.

[2] ___ NBR 6459: Solo - Determinação do limite de liquidez - Método de ensaio. Rio de Janeiro, 1984.

[3] ___ NBR 7180: Solo - Determinação do limite de plasticidade - Método de ensaio. Rio de Janeiro, 1984.

[4] __ _ NBR 7181: Solo - Análise granulométrica - Método de ensaio. Rio de Janeiro, 1984.

[5] BERNUCCI, Liedi Bariani et al. Pavimentação asfáltica: formação básica para engenheiros. Rio de Janeiro: Abeda, 2006. $544 \mathrm{p}$.

[6] BRASÍLIA. Cnt. Confederação Nacional do Transporte (Org.). Acidentes rodoviários e infraestrutura. 2018. Disponível em: <https://cnt.org.br/acidentes-rodoviarios-infraestrutura>. Acesso em: 03 jun. 2019.

[7] DEPARTAMENTO NACIONAL DE ESTRADAS DE RODAGEM. ME 093/94 - Determinação da densidade real. 1994.

[8] DNIT (2006). Manual de pavimentação. Publicação IPR - 179. Ministério dos Transportes. Departamento nacional de infra-estrutura de transporte, Instituto de pesquisas rodoviárias.

[9] IBGE. Cidades e Estados. Disponível em: <https://www.ibge.gov.br/cidades-e-estados/se.html?>. Acesso em: 13 maio 2019.

[10] PDM. PLANO DIRETOR DE DESENVOLVIMENTO URBANO DE ARACAJU - DIAGNÓSTICO MUNICIPAL. 2015. Prefeitura Municipal de Aracaju. Disponível em: <file:///C:/Users/mayar/Downloads/relatorio-propostas-final.pdf>. Acesso em: 13 maio 2019.

[11] SENÇO, Wlastermiller de. MANUAL DE TÉCNICAS DE PAVIMENTAÇÃO. 2. ed. São Paulo: Pini, 2007. 1 v. 


\section{Capítulo 6}

\section{Inspeção e catalogação de manifestações patológicas}

em estrutura metálica de terminal de integração

\section{Iris Sterfanie Santos \\ Leonardo Medina Rosário \\ Ihana Gabriela Conceição de Jesus}

Resumo: Os aços estruturais são difundidos na engenheira civil, seja na utilização como elemento de reforço a tração em estrutura de concreto ou em sua utilização plena, como estrutura metálica. Dentre suas características está alta resistência a tração e ductilidade, além de agilidade no processo construtivo, onde, em obras públicas pode conferir comodidade e conforto ao usuário. Contudo, como todo sistema construtivo necessita de manutenções, a sua ausência, seja de ordem preventiva ou corretiva, acarreta em danos críticos a estrutura metálica, que podem levar ao comprometimento do sistema e sua integridade. Nesse cenário, buscou-se analisar e catalogar manifestações patológicas presentes em estrutura metálica de terminal de integração do município de Aracaju SE, inferindo origem, causa e grau de urgência nas intervenções. A análise foi realizada a partir de anamnese, inspeção visual e ensaio com líquido penetrante. A partir dos resultados obtidos pode-se constatar uma estrutura com graus variados de deterioração e presença de corrosão, sobretudo em pontos de solda e perfis treliçados. O grau de urgência, com maior percentual crítico, infere ausência de manutenções ou manutenções ineficientes. 0 cenário leva a corroborar a respeito da ausência de cuidados e planos de manutenção em obras públicas, bem como atuação da população como contribuinte para degradação de patrimônio público.

Palavras-chave: Manifestação patológica. Estrutura metálica. Sistema GUT. 


\section{INTRODUÇÃO}

O sistema integrado de transporte urbano nasceu como uma alternativa para aperfeiçoar a mobilidade urbana, ou seja, expandir a acessibilidade ao transporte, aumentar a mobilidade e reduzir custos aos usuários (ANTP, 2004). 0 tipo de estrutura utilizado nos terminais de integração do Brasil, são basicamente estrutura metálica, em concreto e mista (RIBEIRO, 2009).

A estrutura metálica possui como diferencial em relação as outras, rapidez na execução, o que em obras públicas torna-se crucial. Os principais requisitos para aplicações como aço estrutural são elevada tenacidade, tensão de escoamento, homogeneidade microestrutural, boa soldabilidade e trabalhabilidade em operações (TEOBALDO, 2004). Com relação a sua conservação, a forma mais comum e eficaz é mantêla protegida por um sistema de revestimento (GARDNER, 2019).

A escolha do sistema de pintura apropriado considera aspectos como o tipo e vida esperada, clima local e outras condições ambientais (KREISLOVA e GEIPLOVA, 2012). De acordo com Kreislova e Geiplova (2012), é essencial ter acesso a toda a superfície para a pintura inicial e de manutenção. A ISO 8501-3 exige uma preparação rigorosa para evitar a corrosão, porém solda em desacordo com a norma e não tratadas, resulta no início da falha do revestimento (KOGLER, 2005).

A corrosão é apontada como a principal manifestação patológica em estrutura metálica, seguida de patologia das ligações, deformação e fadiga, as quais geram contaminação, deterioração, descontinuidade e perda de material (CASTRO, 1999) (SCHINCA, 2010) (COSTA, 2012). De acordo com Gardner (2019) fissuras por fadiga e falha de revestimento são dois tipos principais de deterioração.

Quando as manifestações patológicas estão presentes na estrutura, um diagnóstico preciso deve ser estabelecido para identificação e correção do problema (LICHTENSTEIN, 1989). A estimativa das prováveis consequências dos danos e a tomada de medidas emergenciais são uma posição importante tomada pelo responsável pela vistoria (RIPPER e SOUZA, 1998).

Desse modo, estudo em questão se propôs a analisar as manifestações patológicas presentes em estrutura metálica de um terminal de integração através da inspeção visual e ensaio não destrutivo, para catalogação das manifestações patológicas, inferência das causas e origem e indicação de medidas profiláticas de acordo com o grau de necessidade anomalia ou falha.

\section{METODOLOGIA}

O estudo foi desenvolvido em um Terminal de Integração construído em estrutura metálica localizado próximo ao Rio Sergipe, município de Aracaju SE. 0 terminal em questão possui duas plataformas e alto fluxo de passageiros, pois atende demanda de municípios vizinhos, e está em pleno funcionamento desde janeiro de 2000 (Figura 1).

Figura 1: Localização e indicação das plataformas do terminal de integração

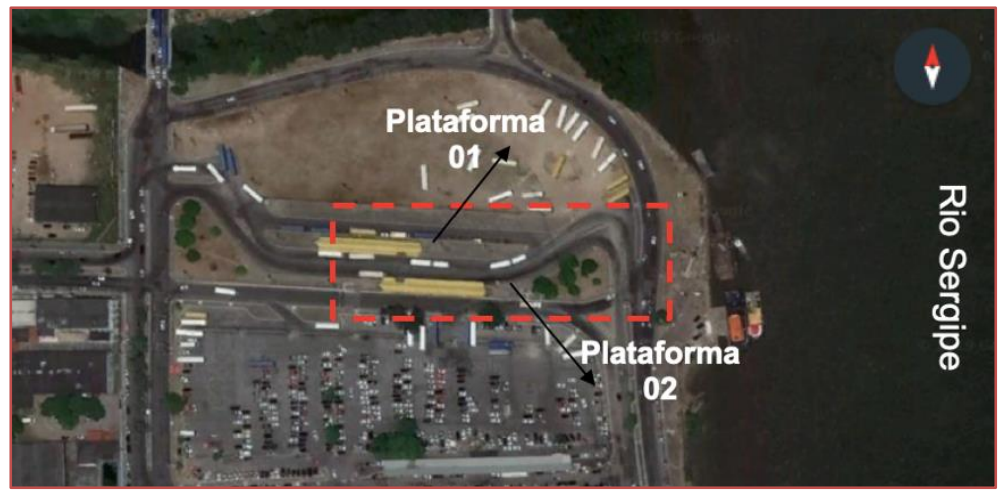

Fonte: Google Earth, 2017. 
O terminal de integração em questão é um bem público, de responsabilidade do município e as manutenções realizadas por empresas de transporte coletivo. Desse modo, antes de adentrar ao espaço, foi encaminhado à Superintendência Municipal de Transportes e Trânsito (SMTT) um Ofício com o intuito de formalizar a entrada e solicitar a autorização para realização da pesquisa.

A coleta de dados foi dividida em duas etapas. A primeira etapa correspondeu a entrevista com a engenheira civil responsável pela fiscalização na época da construção do terminal e pesquisa bibliográfica com busca de matérias da mídia digital de 2000 a 2017, ambos com o intuito de traçar o histórico da estrutura, resultando em uma anamnese detalhada.

A segunda etapa correspondeu a vistoria, inspeção visual e realização de ensaio. A vistoria foi realizada inicialmente para reconhecimento do ambiente e confecção de um roteiro de inspeção. A inspeção visual foi realizada posteriormente cujo objetivo foi fazer o levantamento das manifestações patológicas na estrutura metálica e realizar o ensaio com líquido penetrante. A inspeção visual seguiu os preceitos da NBR NM 315 (ABNT, 2007).

A partir da inspeção visual foi analisado o acabamento das peças, alinhamento, juntas soldadas, revestimentos, indicação do estado de superfície, deformações e avarias mecânicas e outros pontos que contemplam o presente trabalho. Os materiais utilizados para inspeção foram câmera para registro fotográfico, projeto arquitetônico, trena, prumo, escalímetro e paquímetro.

O ensaio não destrutivo desenvolvido foi com líquido penetrante, cujo objetivo é analisar descontinuidades nos perfis metálicos. Os materiais utilizados para o ensaio foi o penetrante, revelador e removedor. Para execução do ensaio com líquido penetrante, a superfície do perfil tubular inicialmente foi limpa com água, seca e então, aplicado o líquido penetrante a base de água, de cor vermelha, retirando o excesso e após 15 minutos aplicado o revelador (ABNT, 2011), (ABNT, 2012). Com a secagem do revelador, de cor branca, foi possível verificar os pontos onde o material penetrou, caracterizados pela coloração avermelhada.

A avaliação do roteiro de inspeção foi obtida de acordo com a metodologia GUT (Gravidade, Urgência e Tendência) adaptada por Gomide, Neto e Gullo (2009). A metodologia dispõe de um ranking classificatório do potencial de risco e grau de urgência para cada manifestação patológica, com pesos distribuídos em 1 , 3, 6, 8 e 10, que refletem desde "nenhuma" até uma "total" gravidade/urgência/tendência. 0 grau de risco é distribuído em três níveis: crítico, regular e mínimo. O grau "crítico" corresponde a um impacto irrecuperável o qual acarreta em dano a vida, segurança e ao meio, bem como a perda do desempenho do sistema construtivo.

O grau "regular", por sua vez, indica que a estrutura é parcialmente recuperável, existe uma nítida perda da funcionalidade e desempenho, porém a intervenção não precisa ser imediata, mas deve ser feita a curto prazo e por fim, o grau "mínimo" informa a respeito de impactos recuperáveis, causadores de prejuízos pequenos, onde não há probabilidade de risco iminente, onde a intervenção pode ser realizada a médio ou longo prazo (GOMIDE, NETO e GULLO, 2009).

A pintura e as peças que apresentaram corrosão foram analisandas utilizando a NE-009 (ELETROBRÁS, 2016), que apresenta em seu Item 5.1 a classificação da degradação da pintura distribuídas em seis níveis, do Grau 0 ao Grau 10 (Figura 2). 
Figura 2: Grau de deterioração da pintura com descrição da graduação para inspeção

\begin{tabular}{c|l}
\hline $\begin{array}{c}\text { GRAU DE } \\
\text { DETERIORAÇÃO }\end{array}$ & \multicolumn{1}{|c}{ DESCRIÇÄo } \\
\hline Grau 0 & $\begin{array}{l}\text { O severo processo de corrosão do substrato, com muitos } \\
\text { alvéolos, e revestimento sem aderência e com } \\
\text { descascamento intenso. }\end{array}$ \\
\hline Grau 2 & $\begin{array}{l}\text { Pintura com empolamento, perda de cor/brilho, ou manchas } \\
\text { de oxidação do substrato. De 10\% a 33\% da área total } \\
\text { inspecionada com corrosão, bolnas e/ou descascamento do } \\
\text { revestimento. }\end{array}$ \\
\hline Grau 4 & $\begin{array}{l}\text { Pintura com empolamento, perda de cor/brilho, ou manchas } \\
\text { de oxidação do substrato. De 1\% a 10\% da área total } \\
\text { inspecionada com corrosão, bolhas e/ou descascamento do } \\
\text { revestimento. }\end{array}$ \\
\hline Grau 6 & $\begin{array}{l}\text { Pintura com empolamento, perda de cor/brilho, podendo } \\
\text { apresentar as tintas intermediária ou de fundo expostas. } \\
\text { Menos de 1\% da área total inspecionada com corrosão, } \\
\text { bolhas e/ou descascamento do revestimento. }\end{array}$ \\
\hline Grau 8 & $\begin{array}{l}\text { Pintura com empolamento e perda de cor/brilho da tinta de } \\
\text { acabamento. }\end{array}$ \\
\hline Grautura sem alteração em relação à condição inicial.
\end{tabular}

Fonte: NE 009 (ELETROBRÁS, 2016).

A NE-009 apresenta, além da graduação de deterioração da pintura, parâmetros de aceitação e rejeição, com critérios para manutenção corretiva e preventiva.

\section{RESULTADOS E DISCUSSÃO}

O Terminal de Integração é administrado por algumas empresas de ônibus do município, as quais também são responsáveis pelas manutenções periódicas. Com 19 anos de construção, até a presente publicação, passou apenas por uma reforma em 2009 com o intuito de melhorar a acessibilidade. 0 jornal Contexto publicou em 2013 que a estrutura geral dos terminais estava necessitando ser reformada, pois faltava acessibilidade e os banheiros estavam em condições inadequadas. Em maio de 2014 o Jornal do Dia SE publicou a respeito da solicitação realizada por vereador para reformar o local, na Indicação 197/2014 foi pedido urgência, pois o mesmo apresentava problemas na cobertura, nos banheiros, no calçamento e nas sinalizações.

Em outubro de 2014 o Jornal da Cidade.net informou que, segundo o diretor de Planejamento e Sistemas da Superintendência Municipal de Transportes e Trânsito de Aracaju (SMTT), Francisco Navarro, toda a estrutura do Terminal estava condenada e paliativos estavam sendo executados pelas empresas que administravam o terminal até a construção de um novo, pois uma reforma "seria caracterizada como improbidade administrativa". Ainda de acordo com a matéria, o diretor afirmou que a estrutura não suportaria uma reforma, por isso um novo projeto estava sendo elaborado para ser entregue final de 2014 e em janeiro de 2015 encaminhado à Caixa Econômica Federal (CEF) para a liberação da realização da licitação, pois a obra integraria o PAC da Mobilidade.

Em 2015 ocorreram reformas em outros terminais de integração, mas, de acordo com a Agência Jornal de Notícia, o Terminal em questão não seria reformado, pois iria passar por uma intervenção maior, passando a atender todo o centro da cidade, inclusive frota de terminal vizinho, pois este seria desativado. Contudo, até a presente publicação o Terminal permanece com as condições declaradas e a demolição e construção de um novo Terminal não foi realizada.

Com relação aos ensaios de campo, a inspeção visual no Terminal resultou na catalogação das manifestações que estavam presentes em seus sistemas construtivos, sobretudo estrutural. O Terminal apresenta variabilidade de manifestações patológicas, voltadas em sua maioria para corrosão, manifestação característica de estruturas metálica (CASTRO, 1999), (SCHINCA, 2010), (COSTA, 2012) (Figura 3). 
Figura 3: Identificação e incidência de manifestações patológicas em terminal de estrutura metálica

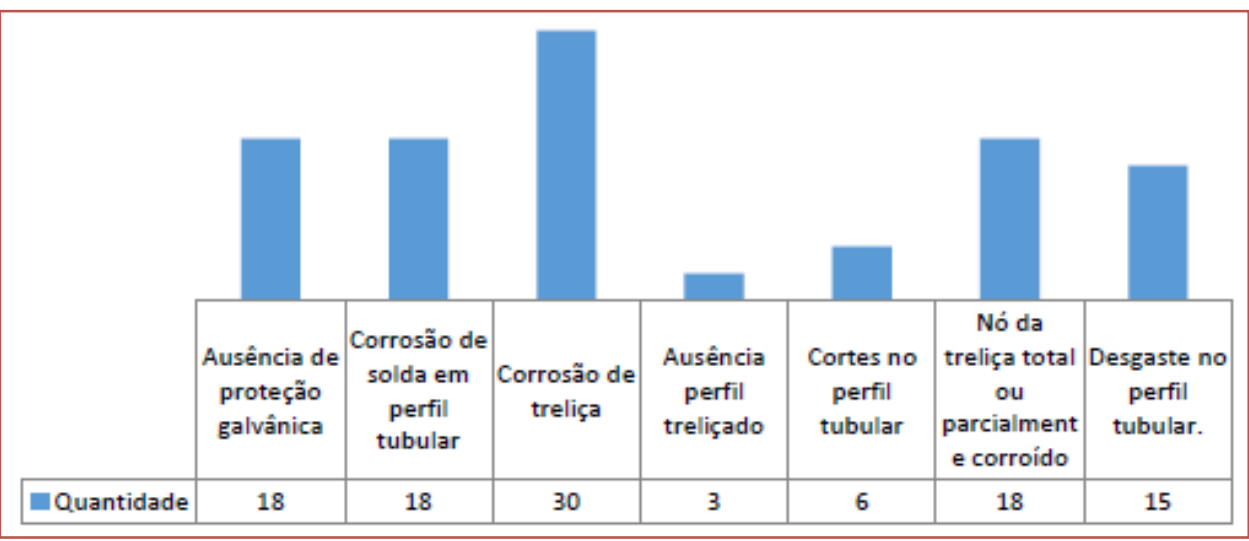

Fonte: autor (2017)

A corrosão estava presente em pontos de solda da estrutura tubular, nós e perfis treliçados, porém não foi observada corrosão nos perfis tubulares dos pilares e vigas, apenas degradação significativa da pintura (Figura 4). Os pontos de solda da estrutura tubular correspondiam a união vigas e pilares. A corrosão nesses pontos podem ser oriundas da diferença de potencial gerada durante o processo de soldagem, bem como deficiência ou ausência da pintura de proteção ou comprometimento e descascamento da pintura oriundos de fatores externos ou alcance da vida útil da pintura.

Figura 4: Corrosão de ponto de solda localizado na conexão viga-pilar em terminal de estrutura metálica

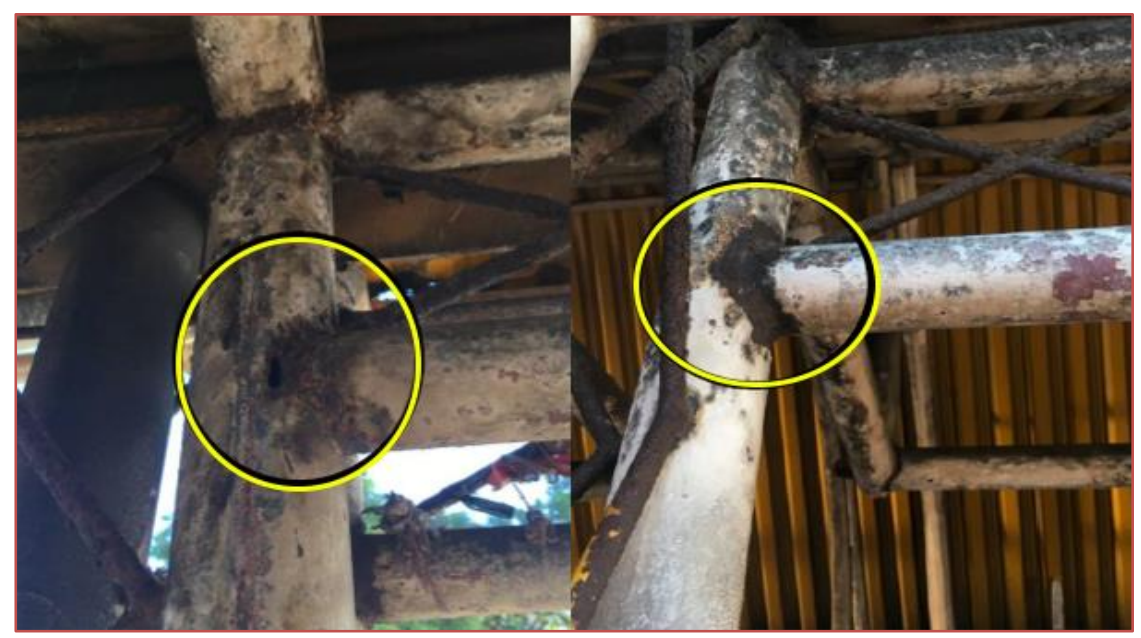

Fonte: autor (2017)

Os perfis treliçados dos pilares apresentavam-se parcialmente ou totalmente corroídos, porém os perfis treliçados das vigas encontravam-se totalmente corroídos na Plataforma 01 e parcial a totalmente corroídos na Plataforma 02. Dos pontos de solda que se encontravam oxidados, os nós das treliças foram os mais comprometidos, cujo grau de deterioração se mostrava presente em todos os pilares.

Alguns nós e perfis das treliças estava em estado avançado de corrosão, onde o nó possuia aproximadamente $60 \%$ de sua seção reduzida ou totalmente oxidado, com destacamento da treliça do perfil tubular, resultando perda de sua função estrutural (Figura 5). 
Figura 5: Estado de corrosão avançado em nós e treliças dos pilares do Terminal em estrutura metálica
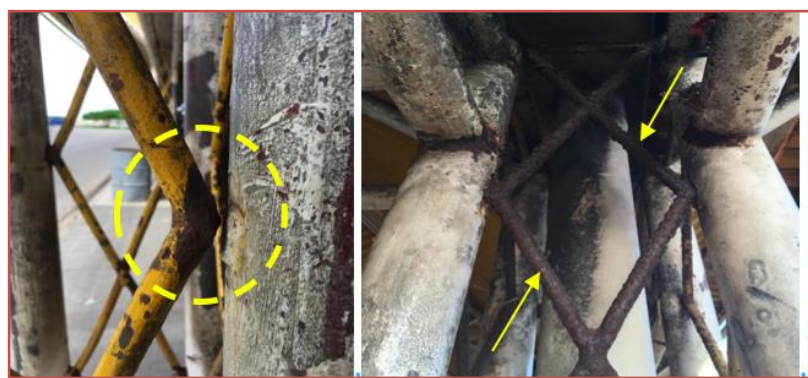

Fonte: autor (2017).

O ensaio com Líquido Penetrante revelou que a peça estrutural não apresentava descontinuidade, pois o penetrante (vermelho) não se mostrou no revelador (branco) em forma de linhas, porém a presença dos pontos infere a existência de microperfurações, podendo ser oriundas da corrosão por pite (Figura 6).

Figura 6: Ensaio com líquido penetrante indicando surgimento de pontos de corrosão por pite em Terminal de estrutura metálica

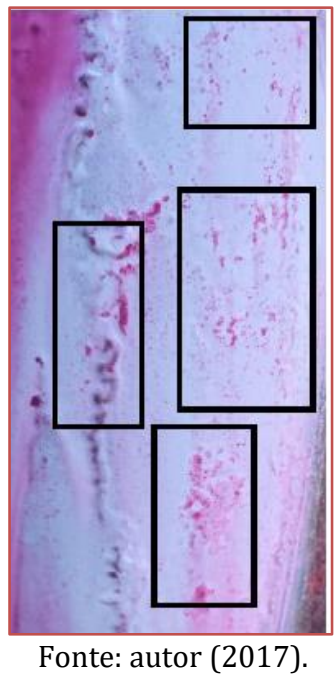

A oxidação foi observada nos pontos de soldas dos perfis tubulares e nos nós da treliça de forma acentuada. Os pontos de solda são elementos que demandam atenção, pois apresentam pré-disposição ao aparecimento de corrosão devido à heterogeneidade resultante de uma diferença de potencial quando o material é aquecido. Contudo, a área em torno da solda - levando em consideração que o cordão de solda é de um material de alta qualidade, passa a funcionar como ânodo, ocorrendo assim o processo de oxidação (CASTRO, 1999).

As causas das manifestações patológicas estão atreladas aos agentes deletérios provenientes da atmosfera, assim como sobrecarga estrutural, vício construtivo e ausência ou ineficiência da pintura (CASTRO, 1999). Em relação a estrutura metálica do Terminal de Integração, o agente causador com impacto significativo pode ser a pintura. De acordo com os projetos observados, não há indicação da especificação da pintura, o que não pode ser afirmado que a pintura original foi inadequada. Contudo, mediante inspeção pode-se constatar que a pintura está perdendo sua função protetora e em muitos pontos ela é inexistente.

A inspeção visual revelou que cerca de $80 \%$ da estrutura metálica estava com pintura comprometida. A graduação da degradação de acordo com o elemento estrutural foi: vigas com Grau 0 e pilares com Grau 0 , 2, 4 e 6. 0 grau de deterioração nos pilares variava de acordo com a altura, com maior grau de degradação na parte superior (Figura 7). 
Figura 7: Degradação da pintura nos elementos estruturais como perfis tubulares dos pilares (a) e vigas (b) e perfis treliçados (c) de Terminal em estrutura metálica

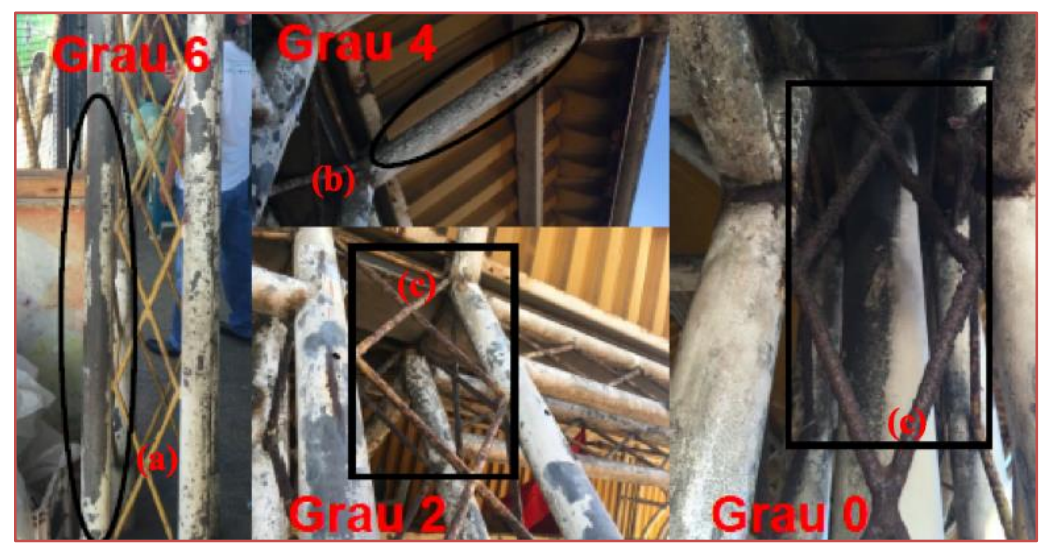

Fonte: autor (2017).

A degradação da pintura Grau 6 e 4 podem indicar uma um defeito de ordem estética, pois gera apenas desconforto visual (CASTRO, 1999). Já a de Grau 2 pode ser classificado, de acordo com Castro (1999), um defeito de ordem geral e, diferente do de ordem estética, resulta no comprometimento da função de proteção que a película de tinta possui.

De acordo com Sartorti (2008), uma maneira de combater a oxidação é a pintura periódica, executadas de 5 a 10 anos, variando de acordo com a região e agressividade ambiental. Contudo, de acordo com a anamnese, pode inferir que não foi realizada pintura periódica dentro do intervalo de construção, apenas serviços referentes a acessibilidade.

O nível de deterioração da pintura e o grau de oxidação apresentado pode não está apenas correlacionado com a ausência de manutenção. A taxa de deterioração do revestimento varia significativamente dependendo do tipo de revestimento, do número de camadas do revestimento, qualidade do trabalho de aplicação de revestimento e condições de exposição que podem incluir vários níveis de severidade dentro de uma estrutura de aço (KREISLOVA et al, 2011).

Aracaju é uma cidade litorânea e quente a maior parte do ano, a radiação UV, por exemplo, pode quebrar o aglomerante, deixando os pigmentos expostos ao ambiente (KREISLOVA et al, 2011). Algumas cores são mais sensíveis a esse tipo de deterioração (azul, branco e cinza claro), mas essas cores são frequentemente requeridas pelos arquitetos (KREISLOVA et al, 2011).

A ausência da proteção/película galvânica e desgaste no perfil tubular deixa o aço completamente exposto a ação de intempérie. Desse modo, tomando os graus de avaliação de degradação da pintura da NE 009 (ELETROBRÁS, 2016), quanto menor era o grau de degradação maior o grau de oxidação da peça.

Desse modo, nas treliças das vigas já se observava formação de escamas no aço e perda de seção por oxidação, com redução de $\emptyset 15 \mathrm{~mm}$ para $\emptyset 14,25 \mathrm{~mm}$ de espessura. Apesar da perda de seção ser aproximadamente $1 \%$ em relação ao diâmetro total, os perfis treliçados e os perfis tubulares são vazados, o que torna o percentual significativo.

A oxidação era mais intensa nas vigas da Plataforma 01 e na parte superior das treliças dos pilares de ambas as plataformas. A diferença do grau de oxidação pode ser explicada devido à inclinação do telhado a qual propicia o acúmulo da fuligem e sua adesão na parte superior do material. A orientação do Terminal em relação ao norte magnético também pode ser fator preponderante. Os ventos NE vindos do Rio Sergipe trazem consigo agentes deletérios da própria atmosfera, como $\mathrm{CO2}$, assim como salinidade do Rio, com concentrações de sódio provindas do mar.

Segundo Gentil (1996), a atmosfera juntamente com seus fatores de umidade relativa, poluentes, gases e temperatura comprometem a película da superfície metálica, como por exemplo um aço sob a ação da umidade relativa do ar a $60 \%$ possui processo corrosivo lento, porém acima de $70 \%$ o processo acelera.

Os perfis tubulares não apresentavam grau de oxidação significativo. Eles apresentavam, além da pintura, proteção galvânica, a qual não foi observada nos perfis treliçados. Desse modo, a espessura ou tipo de tinta 
deveria ser distinto para os elementos estruturas, pois a ausência da proteção galvânica nas treliças induz aplicação de pintura com maior proteção.

Com relação ao desgaste do perfil tubular, este corresponde a ranhuras verticais na peça e a maioria encontram-se localizadas a cerca de $1,50 \mathrm{~m}$ de altura, com comprimento variável, onde os cortes que demandavam atenção estavam localizados em seis pilares (Figura 8). A inspeção visual também revelou presença de furos em todos os pilares com aproximadamente 1,5 cm de diâmetro, onde sua origem pode estar relacionada a furos para suporte de caixas coletoras de lixo.

Figura 8: Furo e corte em pilar com seção tubular de Terminal em estrutura metálica.

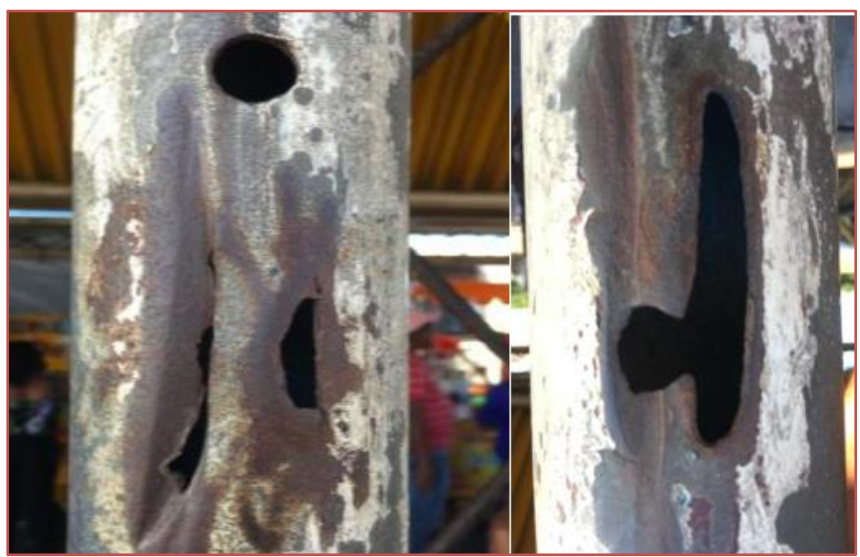

Fonte: autor (2017)

Os cortes apresentavam comprimento que variavam de $2 \mathrm{~cm} \mathrm{a} \mathrm{6,4} \mathrm{cm,} \mathrm{com} \mathrm{abertura} \mathrm{de} \mathrm{1,1} \mathrm{cm} \mathrm{a} 2 \mathrm{~cm}$. Os furos ou cortes podem comprometer o desempenho estrutural e aumentar a propensão à penetração de agentes externos no interior do perfil tubular.

Com relação ao alinhamento dos pilares, foi observado falta de prumo em mais de 50\% dos pilares de ambas as plataformas, variando de 1 a $3 \mathrm{~cm}$. Em virtude do elevado número de elementos estruturais com o defeito, infere-se que a causa pode ser vício construtivo somado a sobrecarga estrutural.

Os pilares, além do desalinhamento vertical, apresentavam flambagem das treliças e descolamento do nó (Figura 9).

Figura 9: Desalinhamento vertical de pilares e deformação de perfis treliçados de Terminal em estrutura metálica

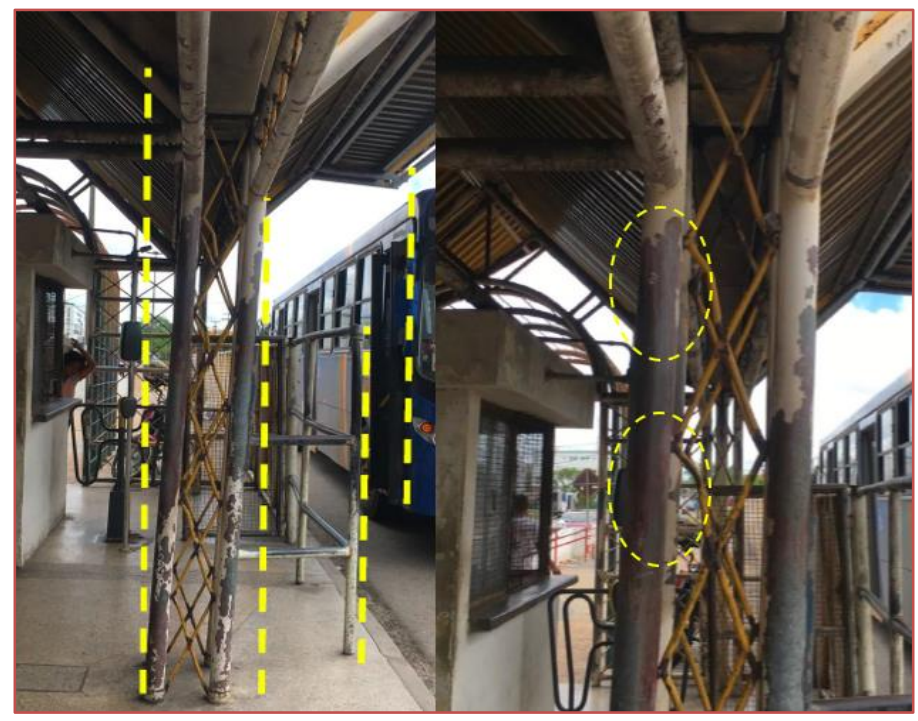

Fonte: autor (2017). 
Dentre os pilares que apresentavam desalinhamento, dois, um em cada plataforma, chamaram a atenção, pois além da visível falta de prumo, apresentava deformação das treliças. As treliças em questão podem funcionar como contraventamento do pilar, isto é, uma estrutura de fixação cujo objetivo é garantir a solidez do elemento estrutural. Entretanto, as treliças não suportaram a compressão sofrida pelos nós, a qual atingiu seu limite de escoamento e deformou plasticamente.

Em síntese, a flambagem do pilar devido ao desaprumo pode ter sobrecarregado as treliças que não suportaram as forças de compressão e deformaram significativamente. Além da deformação, houve o rompimento do nó, causado pela sobrecarga ao grau elevado de oxidação e redução de sua seção.

O pilar da Plataforma 1, com falta de prumo acentuada, pode ser considerado crítico, pois está interligado a uma viga em balanço da cobertura. 0 ponto de solda entre o pilar e a viga da cobertura estava rompido, inferindo que a sobrecarga favoreceu o rompimento. A oxidação presente no ponto de solda pode ter sido fator contribuinte, fragilizando a estrutura, ou pode ter surgiu posteriormente ao rompimento, devido a exposição gerada pela fratura (Figura 10).

Figura 10: Fratura em ponto de solda na união pilar-viga de Terminal em estrutura metálica

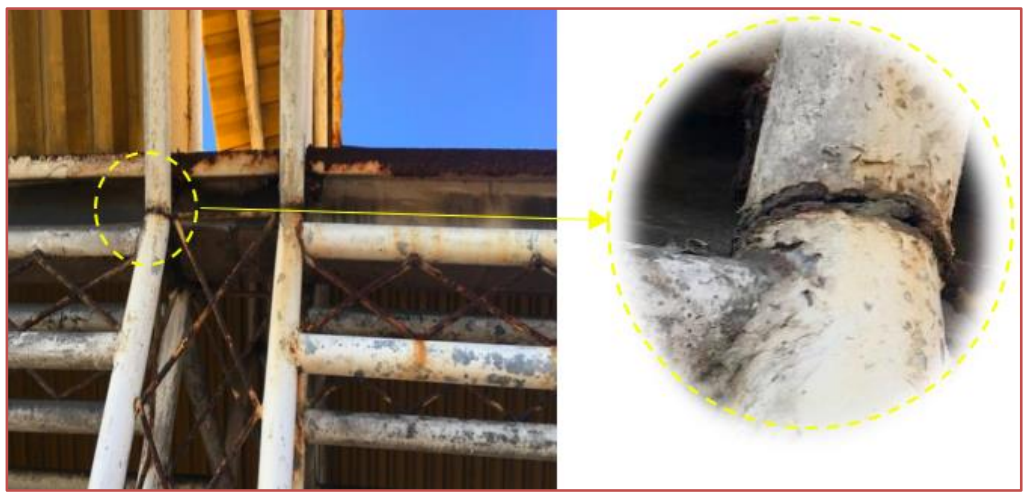

Fonte: autor (2017).

A viga que está transferindo a carga para o pilar da Figura 10 também apresentava pontos de oxidação ao longo do seu comprimento. Além disso, é possível verificar pontos de soldagem numa área do elemento estrutural e nesse mesmo ponto, flambagem da viga (Figura 11).

Figura 11: Viga da cobertura com pontos de corrosão em seu comprimento e ponto de solda na extremidade direita oxidado e flambagem

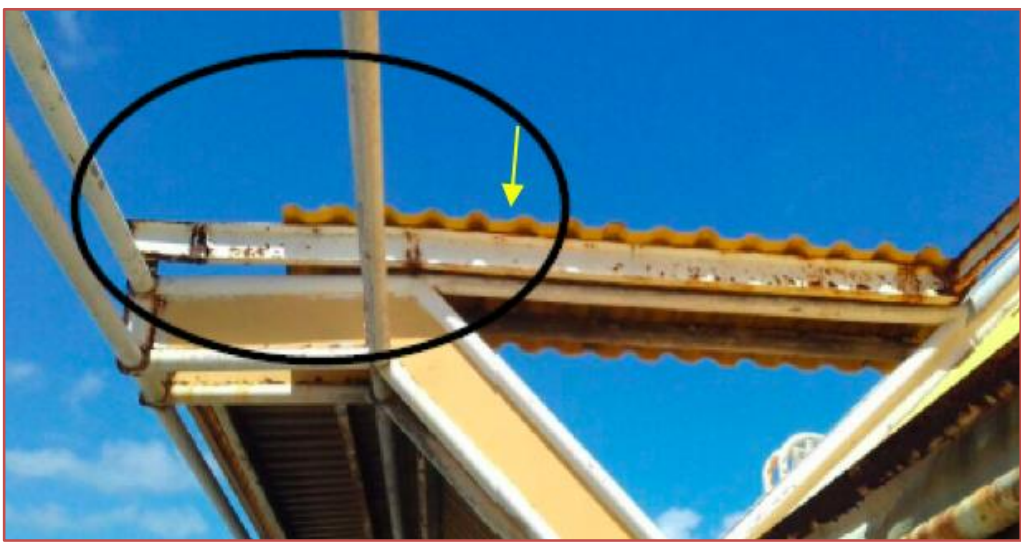

Fonte: autor (2017).

A flambagem sofrida pela viga pode estar relacionada a sobrecarga e fragilização do ponto de solda. As cargas da viga da cobertura não são distribuídas de maneira uniforme devido ao comprometimento da 
peça estrutural, sobrecarrega o perfil diagonal e o pilar, os quais não suportam a tensão e rompe no ponto de solda, que, se oxidado, acentua a falta de prumo e a deformação das treliças.

Nesse cenário, a ocorrência da corrosão pode também estar atrelada a magnitude do carregamento. Testes de corrosão em estrutura de concreto armado mostraram que a magnitude e o tipo da carga influenciaram significativa na corrosão da armadura (GARDNER, 2019). Estudos revelaram que a taxa de corrosão de vigas de concreto armado com carga foi maior que vigas sem carga (GARDNER, 2019). Desse modo, quanto maior a carga, mais rápida foi a taxa de corrosão.

A avaliação do grau de urgência das manifestações patológicas presentes na estrutura metálico do terminal de integração, após o levantamento das manifestações foi realizado de acordo com o sistema GUT (GOMIDE, NETO e GULLO, 2009), e mostra-se fundamental para nortear as intervenções (Figura 12).

Figura 12: Grau de urgência das manifestações patológicas de Terminal em estrutura metálica

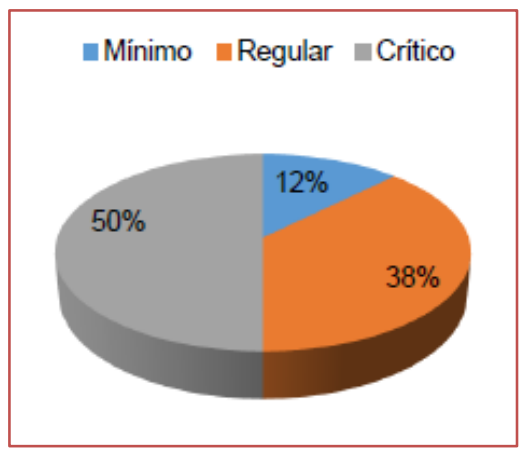

Fonte: autor (2017).

O Terminal apresentou 50\% das manifestações patológicas com grau crítico, necessitando de interferência imediata, porém a maioria das manifestações não é recuperável. A afirmativa do diretor de Planejamento da SMTT, Francisco Navarro, ao Jornal da Cidade.net corrobora com o grau crítico observado, pois o mesmo pontuou em 2014 que a estrutura não suportaria uma reforma.

Cunha e Castro (2016) afirmam que o desempenho do sistema estrutural está correlacionado com seu processo construtivo, bem como uso e manutenção, sendo que a estrutura de aço demanda manutenções periódicas com períodos curtos de tempo, sobretudo ao que tange a pintura.

Das manifestações patológicas cabíveis de intervenção, a ordem de prioridade pode ser estabelecida através do grau de risco e tomando a avaliação do Sistema "GUT" (Tabela 01).

Tabela 1 - Ordem das prioridades das intervenções

\begin{tabular}{|c|c|c|}
\hline Ordem & Manifestação Patológica & GUT \\
\hline $1^{\mathrm{o}}$ & Corrosão em ponto de solda conexão viga-pilar & 480 \\
\hline 2 o & Corrosão das treliças das vigas & 360 \\
\hline $3 \underline{0}$ & Perda da seção em nós de vigas & 180 \\
\hline 4 鱼 & Ausência de proteção galvânica & 90 \\
\hline 5 o & Corte com perda de área de aço & 90 \\
\hline 60 & Deslocamen to do nó & 60 \\
\hline $7 \underline{0}$ & Ranhuras das peças tubulares & 30 \\
\hline $8^{\circ}$ & Furo circular $\varnothing 1,5 \mathrm{~m}$ & 30 \\
\hline
\end{tabular}

De acordo com a Tabela 1, quanto maior a pontuação GUT, maior o grau de atenção a ser dado a manifestação. A corrosão encontrada nos pontos de solda e nas treliças das vigas são os itens de 
prioridade, visto que a oxidação já se encontra num estado moderado, havendo descamação e perda de seção, onde sua evolução pode elevador o comprometimento do desempenho estrutural.

Contudo, para os itens críticos agrupados na Figura 12 e ordem de prioridade da Tabela 1, é indicado intervenção imediata com escoramento da estrutura e acompanhamento do comportamento estrutural, a fim de evitar danos à segurança dos usuários.

Com relação às medidas de intervenção e o grau de urgência, as manifestações de grau mínimo e regular são passíveis de intervenção corretiva, já que necessita de um reparo, restauração ou substituição de material que venha garantir a restauração do sistema e desempenho originalmente concebido em projeto (CUNHA E CASTRO, 2016). As manifestações críticas, por sua vez, não são passíveis de reparos ou manutenções. As manifestações patológicas de grau crítico estão em maior percentual no Terminal e medidas de intervenção baseadas na ordem de prioridade e um plano de recuperação não se mostra viável.

As medidas preventivas são as primeiras a serem consideradas para manutenção da estrutura, a qual garante o desempenho mínimo e prolonga a vida útil. Contudo, quando as manifestações patológicas elevam seu grau de criticidade, são necessárias intervenções corretivas na estrutura. As medidas corretivas nem sempre apresentam viabilidade econômica e em situações críticas deve abdicar da manutenção corretiva e adotar a recuperação ou mesmo demolição da estrutura.

\section{CONSIDERAÇõES FINAIS}

A estrutura metálica do Terminal de integração apresenta manifestações patológicas que necessitam de atenção especial, pois estão contribuindo para a redução da eficiência estrutural e segurança dos usuários. A manifestação mais recorrente e de elevado grau de urgência foram os pontos de oxidação distribuídos nos pilares, vigas, treliças e cobertura, que variou de grau leve a severo, desencadeando outras manifestações e contribuindo para o comprometimento da vida útil da construção.

o Terminal analisado não se mostra passível de intervenção preventiva devido a evolução das manifestações patológicas presentes, assim também como uma recuperação estrutural não apresentaria viabilidade econômica. De acordo com os resultados da inspeção e ensaios seria indicado escoramento dos elementos estruturais com grau crítico e, tratando-se de órgão pública, licitação para demolição e nova construção.

Os fatos observados reforçam a importância da manutenção, mostrando-se crucial e determinante para manter as condições de uso do sistema construtivo. Esse conjunto de ações preventivas garante a durabilidade e desempenho. As manifestações oriundas do uso inadequado, quando se trata de bem público, como os terminais de integração, exige uma corresponsabilidade da sociedade a qual deve zelar pela integridade do patrimônio. Por fim, compete aos fiscais e administradores criar planos de manutenção com o intuito de elevar a vida útil e dirimir os danos causados.

\section{REFERÊNCIAS}

[1] AGÊNCIA JORNAL DE NOTÍCIA. Prefeitura de Aracaju reforma Terminais de Integração. Sergipe, 2015. Disponível em <https://ajn1.com.br/prefeitura-de-aracaju-reforma-terminais-de-integracao/>. Acessado em 06 de julho de 2017.

[2] ASSOCIAÇÃO BRASILEIRA DE NORMAS TÉCNICAS. NBR NM 315:2007 - Ensaios não destrutivos - Ensaio visual - procedimentos.

[3] ASSOCIAÇÃO BRASILEIRA DE NORMAS TÉCNICAS. NBR NM 327:2011. Ensaios Não Destrutivos - Líquido Penetrante - Terminologia.

[4] ASSOCIAÇÃO BRASILEIRA DE NORMAS TÉCNICAS. NBR NM 334:2012. Ensaios Não destrutivos - Líquidos Penetrantes - Detecção de descontinuidades.

[5] ASSOCIAÇÃO NACIONAL DE TRANSPORTES PÚBLICOS (ANTP). Súmula da 3a reunião da comissão de integração de sistema de transporte e desenvolvimento de terminais de passageiros. São Paulo: Banco Nacional de Desenvolvimento Econômico e Social, 2004.

[6] CASTRO, Eduardo Mariano Cavalcante de. Patologia dos edifícios em estrutura metálica. Dissertação. Universidade Federal de Ouro Preto. Ouro Preto: 1999. 
[7] CONTEXTO ONLINE. Terminais de integração aguardam reformas. Universidade Federal de Sergipe: Jornal laboratorial dos estudantes de jornalismo, 2013. $\quad$ Disponível em <https://ufscontexto.wordpress.com/2013/12/19/terminais-de-integracao-aguardam-reformas/>. Acessado em 06 de julho de 2017.

[8] COSTA, Fabio Gomes da. Manutenção das estruturas metálicas com utilização dos ensaios não destrutivos. Congresso Latinoamericano da Construção Metáliza, 2012.

[9] CUNHA E CASTRO, Tiago Felipe. Manutenção em estruturas de concreto armado baseado no conceito de manutenção centrada em confiabilidade. São Paulo: Escola Politécnica da Universidade de São Paulo, 2016.

[10] ELETROBRÁS. NE 009:2016. Classificação do grau de degradação em pintura.

[11] GARDNER, Leroy. Stability and design of stainless steel structures: Review and outlook. Thin-Walled Structures. 2019, vol 141, p 208-216.

[12] GENTIL, Vicente. Corrosão. 3a Edição. Rio de Janeiro: Livros Técnicos e Científicos, 1996.

[13] GOMIDE, Tito L. F.; NETO, Jerônimo C. P. F. e GULLO, Marco A. Engenharia Diagnóstica. 2ª Ed. Rio de Janeiro: Pini, 2009.

[14] JORNAL DA CIDADE.NET. Usuários criticam situação do terminal do mercado. Sergipe, 2014. Disponível em <http://jornaldacidade.net/noticia-leitura/66/80017/usuarios-criticam-situacao-do-terminal-domercado.html\#.WWtf2NTytdg>. Acessado em 06 de julho de 2017.

[15] JORNAL DO DIA ONLINE. Iran solicita reforma dos terminais de integração de ônibus de Aracaju. Sergipe, 2014. Disponível em <http://www.jornaldodiase.com.br/noticias_ler.php?id=10520>. Acessado em 06 de julho de 2017.

[16] KOGLER, R. Weathering steel and painted steel: complementary corrosion protection solutions for highway bridges. Journal of Protective Coatings and Linings, vol 22, 2005.

[17] KREISLOVA, Katerina; GEIPLOVA, Hana; LANIK, Tomas. The effect of road environment on corrosion of the infrastructure $\quad$ constructions. $2011 . \quad$ Disponível em <http://www.svuom.cz/images/publikace/clanky/2011_the_effect_of_road.pdf>. Acessado em 15 de julho de 2019.

[18] LICHTENSTEIN, Norberto B. Patologia das construções: procedimento para diagnóstico e recuperação. São Paulo: Boletim técnico, 1989.

[19] RIBEIRO, Paulo de Castro. Terminal urbano de integração no Brasil: análise crítica de sua arquitetura. Dissertação de Mestrado apresentada ao Programa de Pós-graduação em Arquitetura, Faculdade de Arquitetura e Urbanismo, da Universidade Federal do Rio de Janeiro, 2007.

[20] RIPPER, Thomaz; SOUZA, Vicente Custódio Moreira de Souza. Patologia, recuperação e reforços de estruturas de concreto. 1ª Edição. São Paulo: Pini,1998.

[21] SARTORTI, Artur Lenz. Identificação de patologias em pontes de vias urbanas e rurais no município de Campinas-SP. Dissertação - Faculdade de Engenharia Civil, Arquitetura e Urbanismo. Universidade Estadual de Campinas, 2008.

[22] SCHINCA, Jorge. Patología en elementos estructurales: madera, hierro - acero y muro portante cerámico. 2010. Disponível em <https://www.colibri.udelar.edu.uy/bitstream/123456789/4352/5/JEL65.pdf>. Acessado em 02 de julho de 2017.

[23] TEOBALDO, Izabela Naves Coelho. Estudo do aço como objeto de reforço estrutural em edificações antigas. Belo Horizonte: Dissertação (Mestrado em Engenharia de Estruturas) - Escola de Engenharia - Universidade Federal de Minas Gerais, 2004. 


\section{Capítulo 7}

\section{A degradação da nascente do Riacho do Xoxota no município de São Cristóvão por despejo de efluentes domésticos}

\section{Caynara Santos Costa}

\section{Almir Querino de Melo}

Resumo: os impactos causados pelo crescimento acelerado e desordenado da população têm acarretado em inúmeros prejuízos ao meio ambiente, dentre eles, a poluição da água por despejo de efluentes domésticos. 0 devido tratamento desses resíduos antecedendo o seu lançamento ao meio ambiente ou em corpos d'água já é uma realidade em países desenvolvidos, porém, em países em desenvolvimento, que é o caso do Brasil, a coleta e tratamento de efluentes domésticos ainda apresentam taxas muito baixas. Diante disso, o presente trabalho tem por objetivo analisar as preocupantes alterações ocorridas na nascente do riacho da Xoxota causadas pelo despejo de efluentes líquidos. Para isso, é necessário identificar as ações antrópicas nela ocorridas, além de avaliar a sustentabilidade dos sistemas de esgotamento sanitário. Para tanto, foram feitas abordagens e definições relativas ao tema de acordo com as legislações vigentes e literatura. Os procedimentos metodológicos incluem pesquisas bibliográficas e documentais, observações em nível local e ao longo do curso d'água no limite de 300 metros lineares a partir da nascente, permitindo assim, a análise macroscópica da área estudada, bem como os fatores que vêm causando a assolação desta no que diz respeito à falta de saneamento básico. Para isso, a busca por novas soluções para os serviços de saneamento da região se faz necessária, em conjunto com a participação comunitária, de forma a cientificá-la sobre a importância da preservação da nascente.

Palavras-chave: Meio ambiente, ação antrópica, saneamento básico 


\section{INTRODUÇÃO}

Os recursos oferecidos pela natureza são essenciais para a manutenção da vida, seja humana, animal ou vegetal. A água é um desses recursos, vital para todos os seres. 0 crescimento acelerado e desordenado da população tem acarretado impactos significativos ao meio ambiente. Os serviços de saneamento básico de baixa qualidade e a falta de fiscalização por parte de órgãos competentes tem contribuído para o aumento da degradação do meio ambiente, principalmente no que se refere aos corpos hídricos.

Nos dias atuais, diversos sistemas de abastecimento e coleta para os serviços de saneamento tem se modernizado. Em países desenvolvidos o tratamento dos resíduos domésticos antecede o lançamento no meio ambiente ou em corpos d'água. O Brasil já possui diversas estações de tratamento de esgoto, mas, infelizmente, as taxas de esgotamento sanitário coletado e tratado antes do despejo ainda são muito baixas.

Em Sergipe não é diferente, de todo esgoto produzido no Estado, apenas $21,64 \%$ possui coleta e tratamento adequado e mais de $55 \%$ da população não possui coleta e tratamento de esgoto. Ao focar no município de São Cristóvão, este número é ainda maior, $61,30 \%$ da população não possui coleta e tratamento adequado e apenas $25 \%$ coletada pela única estação de tratamento do município, situada no bairro Eduardo Gomes.

Nesse sentido, a pesquisa objetiva analisar a degradação ambiental por despejo de efluentes líquidos na nascente do Riacho do Xoxota em São Cristóvão e desta forma será necessário identificar os tipos de ações antrópicas ocorridas na nascente, bem como avaliar a sustentabilidade dos sistemas de esgotamento sanitário do entorno.

\section{METODOLOGIA}

A metodologia empregada neste trabalho visa demonstrar o tipo de pesquisa e como fora desenvolvida a coleta, análise e tratamento das informações.

Prodanov (2013, p. 14) define metodologia como sendo:

A aplicação de procedimentos e técnicas que devem ser observados para construção do conhecimento, com o propósito de comprovar sua validade e utilidade nos diversos âmbitos da sociedade.

Sendo a quarta cidade mais antiga do país, São Cristóvão foi fundada em 1590 por Cristóvão de Barros e foi a primeira capital do estado de Sergipe até o ano de 1855, quando o então Governador Inácio Joaquim Barbosa transferiu a capital para Aracaju, alegando a necessidade de um porto para comercialização de açúcar e do algodão (IBGE, 2018).

O Município de São Cristóvão encontra-se localizado a $25 \mathrm{~km}$ da capital Aracaju (Figura 1), no leste do estado de Sergipe, que está situado na região nordeste do Brasil, sendo um dos quatro municípios que compõem a região metropolitana. O município faz fronteiras com o Município de Nossa Senhora do Socorro ao norte, ao sul e a oeste com o Município de Itaporanga D'Ajuda e a leste com Aracaju (BOMFIM, 2002).

Com aproximadamente $4 \mathrm{~km}$ de extensão e classificado como um riacho de água perene, o riacho da Xoxota é um afluente do rio Poxim (Figura 1). Tem uma de suas nascentes localizada na sede da Associação Beneficente Vida sem Drogas, do Conjunto Eduardo Gomes, entre os conjuntos habitacionais Lafaiete Coutinho e Rosa do Oeste, sua localização está compreendida a $10^{\circ} 55^{\prime} 42.6^{\prime \prime}$ latitude sul e 3707'18.4" longitude oeste no Município de São Cristóvão/SE (FERREIRA, et al., 2011; SEMARH, 2012). 
Figura 1. Localização do Município de São Cristóvão e riacho do Xoxota.

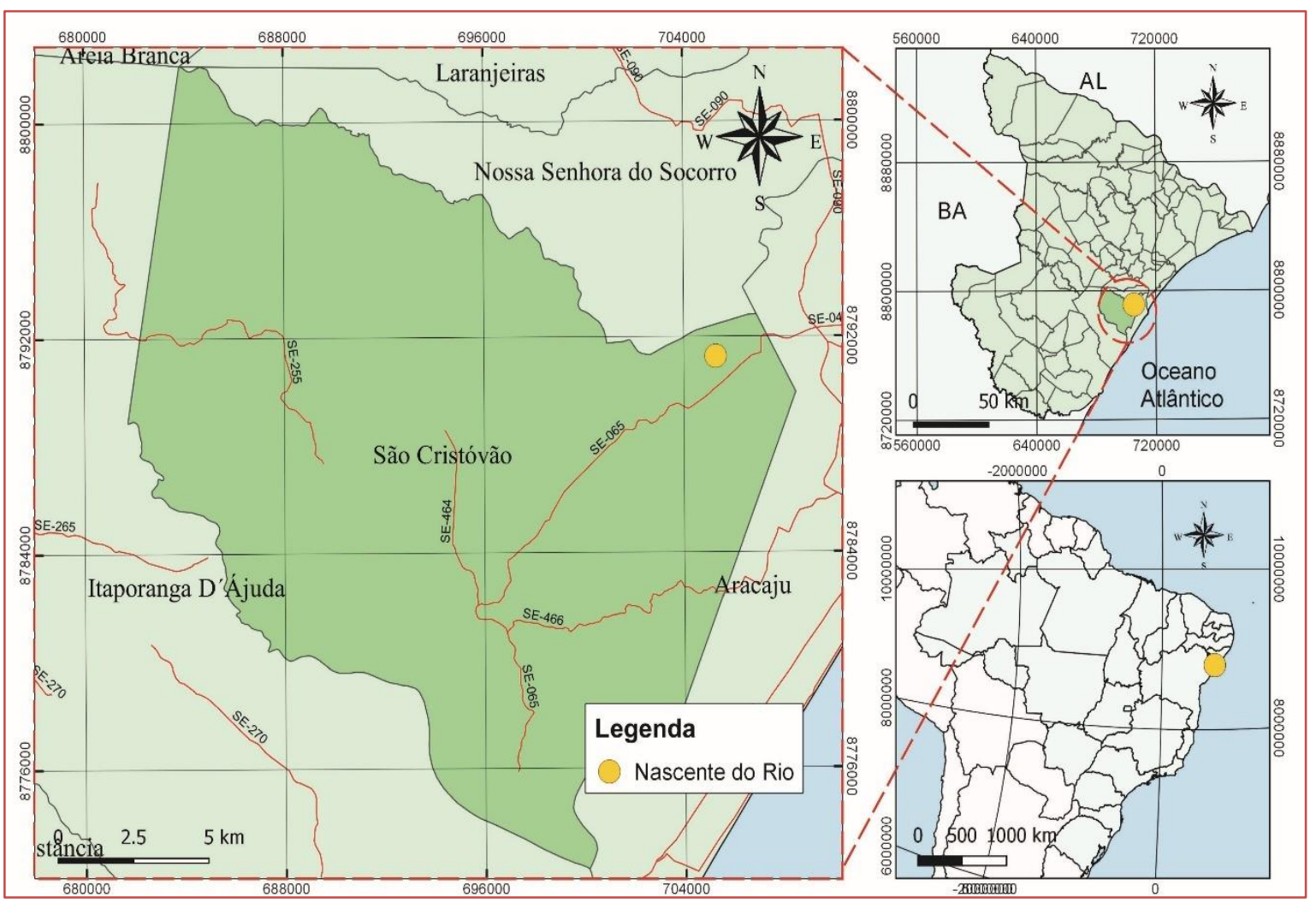

Elaborador: José Carlos Benício do N. Filho ～DATUM: SIRGAS 2000

Fonte: SEMARH - 2016

Ferreira, et al. (2011) classifica a nascente quanto ao estado de conservação e tipo de reservatório, caracterizada como degradada (ausência de vegetação mínima com finalidade de proteção) e difusa (o fluxo ocorre em mais de um local), respectivamente.

É importante salientar que o riacho recebe as águas advindas dos bairros Rosa Elze, Rosa Maria e do Eduardo Gomes, fato que gera a necessidade de ações de limpeza como forma de evitar o acúmulo de dejetos e entulhos e, consequentemente, o alagamento da região em períodos chuvosos (SÃO CRISTÓVÃO, 2018).

Os dados bibliográficos fornecem informações essenciais para conhecimento do tema, uma vez que fornece subsídios necessários para o desenvolvimento do projeto (LAKATOS, 2003).

Diante do tema proposto, foi feito um levantamento bibliográfico e desenvolvidas atividades de fichamento de livros relacionados as temáticas de saneamento, corpos hídricos, meio ambiente e sustentabilidade; artigos científicos publicados em revistas nacionais e internacionais; teses de doutorado encontradas em repositórios de universidades nacionais e internacionais.

Desta forma, conceitos pertinentes ao uso da água no que se refere às instalações sanitárias, desde a sua coleta, tratamento, qualidade, quantidade, passando pela utilização por parte da população até a destinação final foram definidos e serviram de base para o aprofundamento do estudo.

No que diz respeito a natureza, a pesquisa sobre a degradação da nascente de rio no centro de São Cristóvão por despejo de efluentes domésticos é do tipo qualitativa. Quanto ao objetivo, é de caráter exploratório, onde, através da observação direta das regiões circunvizinhas à nascente foram obtidos dados a respeito da situação do local.

A pesquisa qualitativa é exposta de acordo com a abordagem do problema e não é representada em números, nela, o pesquisador obtém através de análise, diversas interpretações, podendo assim, chegar a uma conclusão (RAMOS; RAMOS; BUSNELLO, 2005 apud DALFOVO, 2008). 
O caráter exploratório objetiva a formulação de uma pesquisa, através da identificação dos problemas, cuja questão da presente pesquisa é a degradação de nascente de rio por ações antrópicas, ou levanta hipóteses a serem pesquisadas em futuros projetos a fim de desenvolver, esclarecer e modificar conceitos e ideias (SANTOS, 2016).

O método de observação pode ser comparado ao método experimental, o que os distingue é que na observação é analisado um acontecimento que já ocorreu ou que ainda irá ocorrer e no experimental, o fato é provocado pelo cientista a fim de observar o comportamento de algo (PRODANOV, 2013).

Neste ínterim, as coletas de dados foram feitas in loco como forma de análise macroscópica, através da visita à nascente objeto do estudo entre os dias 04 e 13 de maio de 2019, onde se pode constatar a situação que ela se encontra através da verificação das ações antrópicas ocorridas no local como: despejo de efluentes no rio, existência de mata ciliar no entorno e o raio de abrangência, fatores que foram catalogados e registrados fotograficamente.

De acordo com os dados e informações obtidos através das etapas anteriores, os resultados e discussões serão apresentados objetivando orientar para uma melhor solução à degradação através do modelo Pressão-Estado-Impacto-Resposta - PEIR.

Trata-se de um método adaptado do modelo PER - Pressão-Estado-Resposta, que foi criado pela Organização de Cooperação e Desenvolvimentos Econômicos - OCDE, onde as atividades humanas alteram a qualidade e quantidade de recursos no meio ambiente, exercendo pressão e modificando o seu estado, então a sociedade desenvolve políticas ambientais como forma de resposta.

Devido ao crescimento da degradação ambiental, foi necessário integrar o componente "I", que sugere identificar os impactos causados pela ação antrópica que comprometem o meio ambiente, constituindo assim, a sigla PEIR (KEMERICH, RITTER e BORBA, 2014).

Quanto aos procedimentos técnicos, a pesquisa utilizou:

- Revisão bibliográfica;

- Documental, através de observação direta e levantamento de informações relativas à situação da área;

- E de campo por investigar os tipos de instalações de esgotamento sanitário.

Desta maneira, a pesquisa será desenvolvida através de etapas interligadas.

Uma breve definição sobre o tema faz-se necessário para que possa ser apresentado o universo e amostra da pesquisa. A primeira se refere ao conjunto de elementos contendo determinadas características. 0 conjunto deste trabalho se refere a degradação da nascente, objeto de estudo. E, como subconjunto do universo, a amostra de uma pesquisa é tida como uma parcela selecionada do universo a ser pesquisado, neste caso, às instalações hidrossanitárias localizadas próximo a nascente objeto do estudo, além de outros fatores que ocasionam esta degradação (GIL, 2008; LAKATOS, 2003).

A partir da observação direta conforme descrito na seção 2.2, foi possível quantificar o grau de preservação da nascente realizada através do padrão de quantificação a partir das informações coletadas: I) Cor aparente da água; II) Odor; III) Lixo no entorno; IV) Materiais flutuantes; V) Espumas e óleo; VI) Esgoto; VII) Vegetação; VIII) Uso por animais; IX) Uso antrópico; X) Proteção; XI) Identificação; XII) Residências; XIII) Tipo de área de inserção.

Cada informação possui uma pontuação enquadrada, que será somada e enquadrada conforme o Padrão de Quantificação (Tabela 1) (GOMES, MELO e VALE, 2005).

Tabela 1 - Classificação da nascente quanto ao grau de preservação

\begin{tabular}{c|c|c} 
Classe & Grau de Preservação & Pontuação \\
A & Ótima & Entre 37 e 39 pontos \\
\hline B & Boa & Entre 34 e 36 pontos \\
\hline C & Razoável & Entre 31 e 33 pontos \\
\hline D & Ruim 30 pontos \\
\hline E & Péssimo & Abaixo de 28 Pontos \\
\hline \multicolumn{2}{r}{}
\end{tabular}


Quanto aos elementos da matriz indicadora de sustentabilidade, o método PEIR tem a função de responder as seguintes questões: "o que está acontecendo com o meio ambiente?" (estado); "por que isto está acontecendo?” (pressão); “qual é o impacto?” (impacto); “o que estamos fazendo?” (resposta) (ARIZA e ARAUJO NETO, 2010).

\section{RESULTADOS E DISCUSSÃO}

\subsection{IDENTIFICAÇÃO DOS TIPOS DE AÇÕES ANTRÓPICAS OCORRIDAS NA NASCENTE.}

São vários os problemas constados na atualidade com relação ao meio ambiente, mesmo empiricamente. A olhos nus podem ser observadas diversas formas de degradação ambiental. Esta constatação levou ao estudo de meios que pudessem conservar o ambiente, surgindo então o conceito de sustentabilidade no fim do século XX. Muitas são as definições e entendimentos deste termo.

De forma resumida e rápida entende-se como sustentabilidade a manutenção dos recursos naturais tanto para esta como para as futuras gerações, o que leva a afirmar que as questões ambientais não podem ser entendidas isoladamente, mas de forma ampla e integrada. É preciso um esforço conjunto da humanidade para que se consigam as necessárias transformações. Para alcançar a sustentabilidade, portanto, se faz necessário uma mudança de atitude. Os hábitos dos homens devem ser repensados. A tão sonhada sustentabilidade não depende só de poucos, mas sim de todos e a falta de conscientização nos faz crer que a sustentabilidade ainda é uma utopia, encontrando-se apenas no plano teórico (AFONSO, 2006 apud DALTRO FILHO e SOARES, 2010).

Em menos de vinte anos, o entorno da nascente do riacho da Xoxota sofreu sérias modificações (Figuras 2) (Figura 3). Estas modificações vêm ocasionando sérios problemas, dentre eles, o impacto ambiental negativo como aterro da nascente, lançamento de resíduos sólidos, desmatamento e invasão urbana.

Figura 2: Imagens via satélite do riacho do Xoxota no ano de 2003

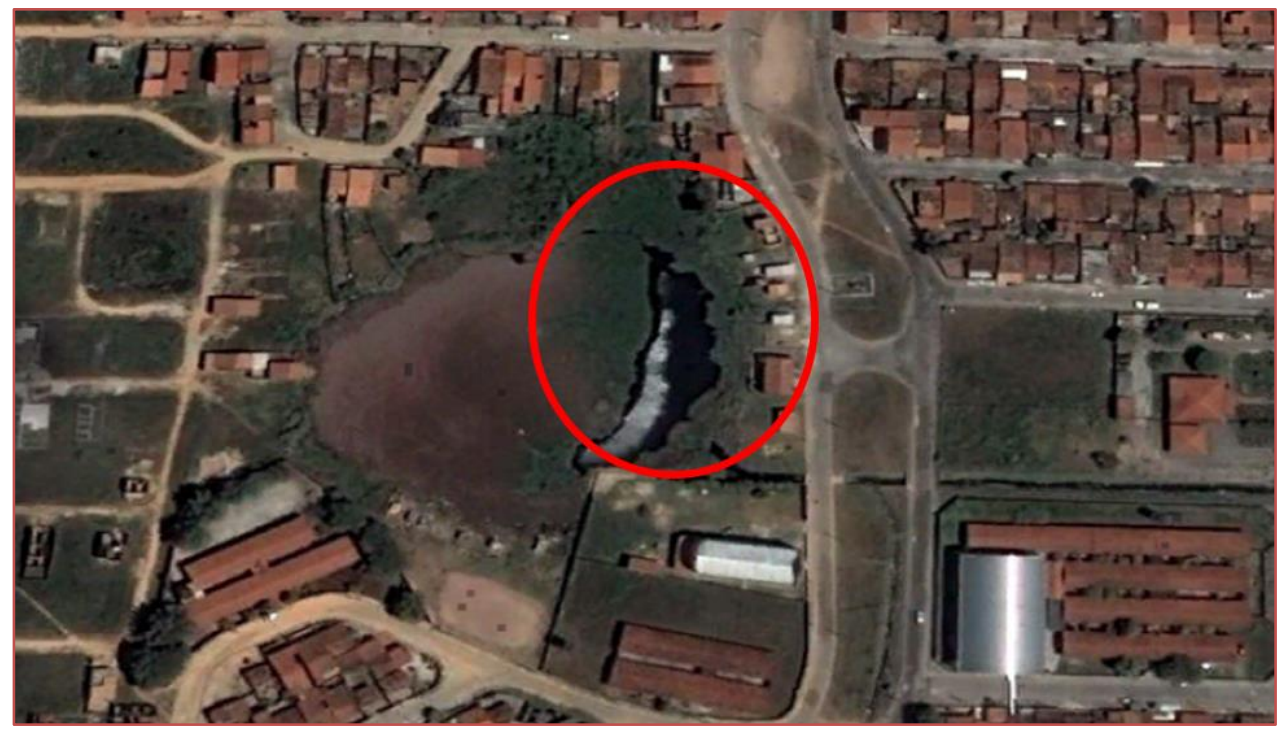

Fonte: Google Earth, 2018. 
Figura 3: Imagens via satélite do riacho do Xoxota no ano de 2017

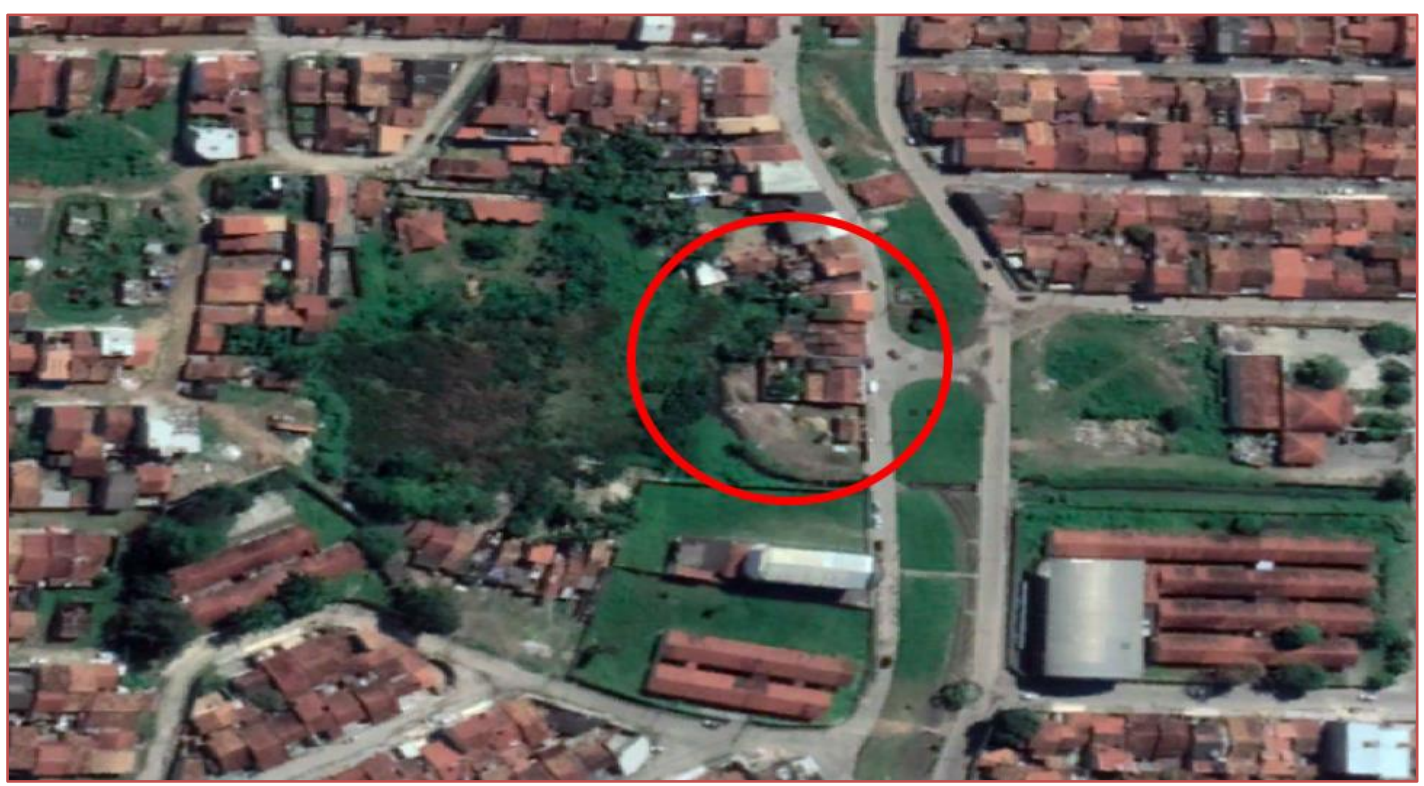

Fonte: Google Earth, 2018.

Com base nas observações realizadas in loco, de acordo com os parâmetros, a nascente está enquadrada na classe "E", obtendo 21 pontos, considerada como grau de preservação péssima.

Foram encontrados: a água apresentou duas colorações diferentes, a primeira foi de coloração escura, com odor forte, sem presença de espumas e óleos na superfície, identificadas em visita feita dia 04 de maio de 2019 (Figura 4). Já na visita realizada dia 13 de maio do mesmo ano, verificou-se a coloração marrom clara, decorrente das chuvas ocorridas no período da noite anterior (Figura 6).

Figura 4: Evidência da alteração da coloração da água

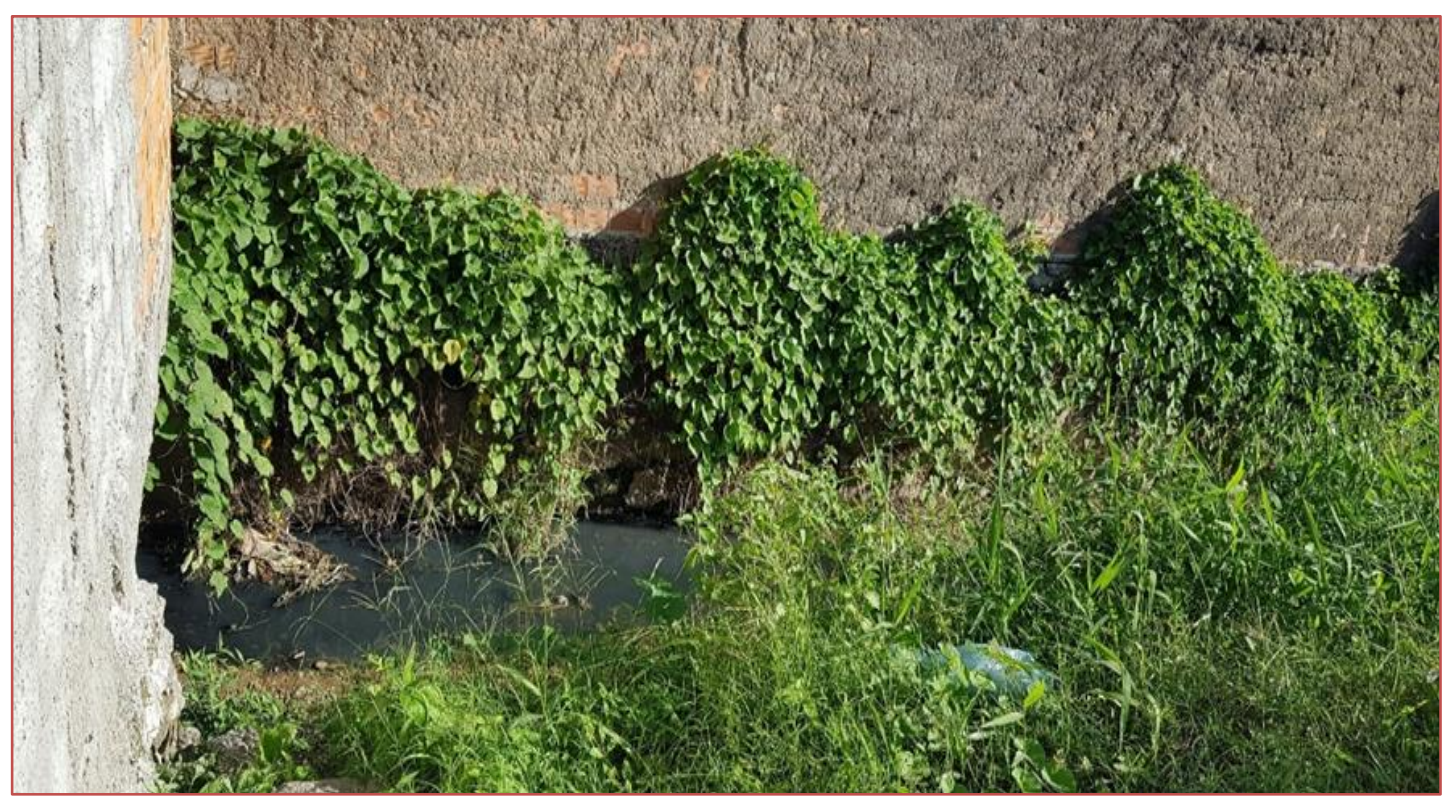

Fonte: autor, 2019.

No que diz respeito a esgoto doméstico, não foram detectadas ligações com a nascente, porém, ao analisar o curso do riacho, é possível observar o desague de águas cinzas advindas da rede de águas pluviais (Figura 5). 
Figura 5: Desague de esgoto doméstico no curso do riacho

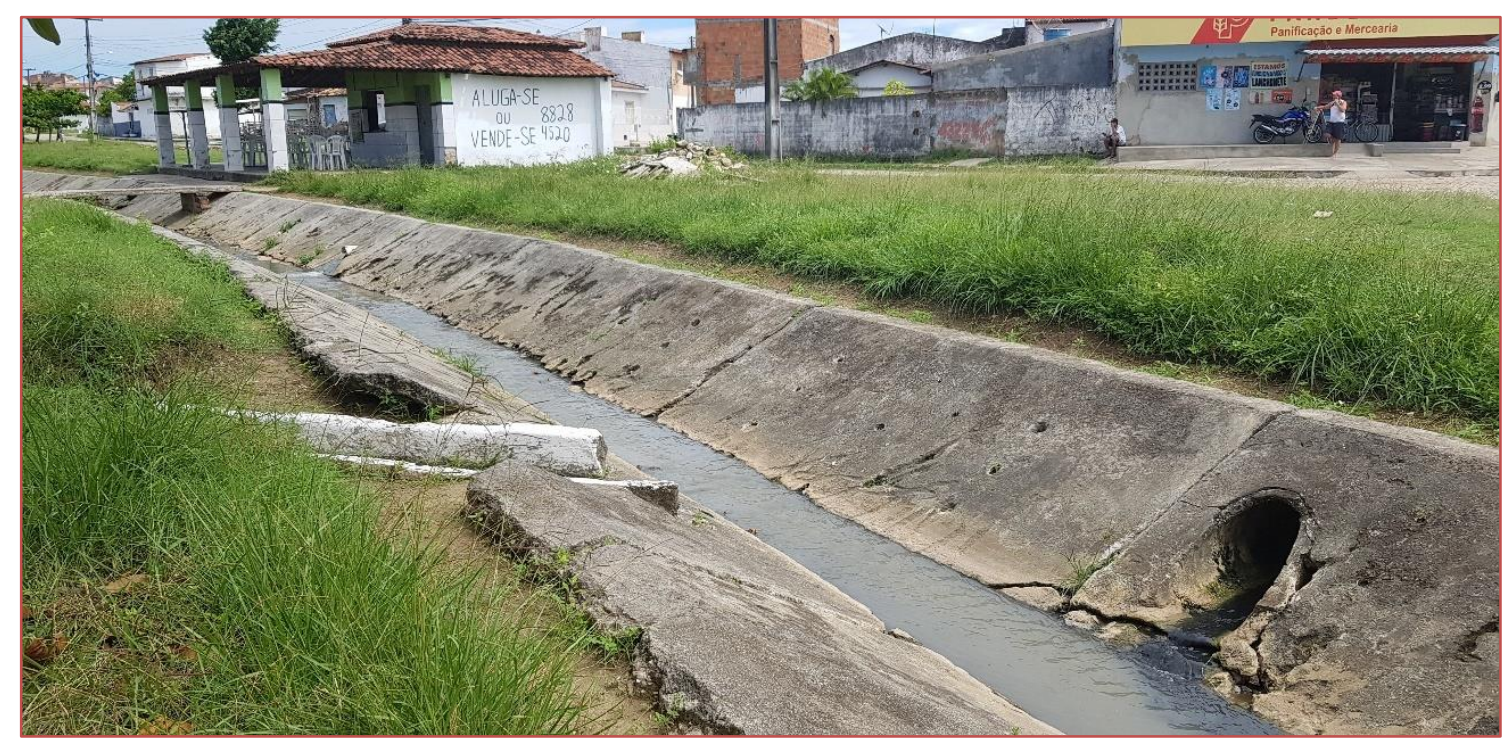

Fonte: autor, 2019.

Às margens da nascente, identificou-se elevada quantidade de resíduos da construção civil - RCC, juntamente com embalagens plásticas, de alumínio, isopor, dentre outras, advindas do lixo doméstico (Figura 6), bem como o acúmulo desses mesmos tipos de materiais flutuando nas águas (Figura 7). É possível identificar também o depósito de RCC ao longo do curso do riacho (Figura 8). 0 lançamento deste material em local indevido, descumpre o que determina o Art. 4ํㅡ, § 1ํ da Resolução no $307 / 2002$ do CONAMA, que informa que os resíduos provenientes da construção civil não devem ser dispostos em corpos d'água.

Figura 6: RCC depositados no entorno da nascente

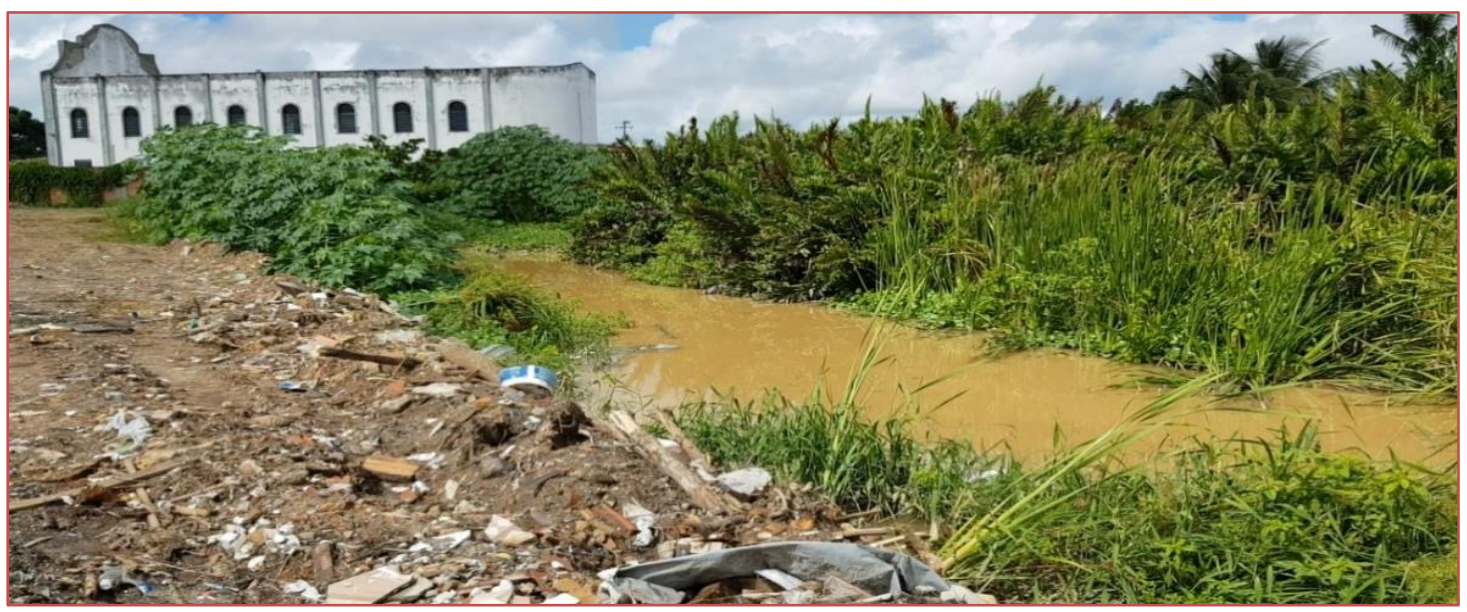

Fonte: autor, 2019. 
Figura 7: Lixo flutuante acumulado na nascente

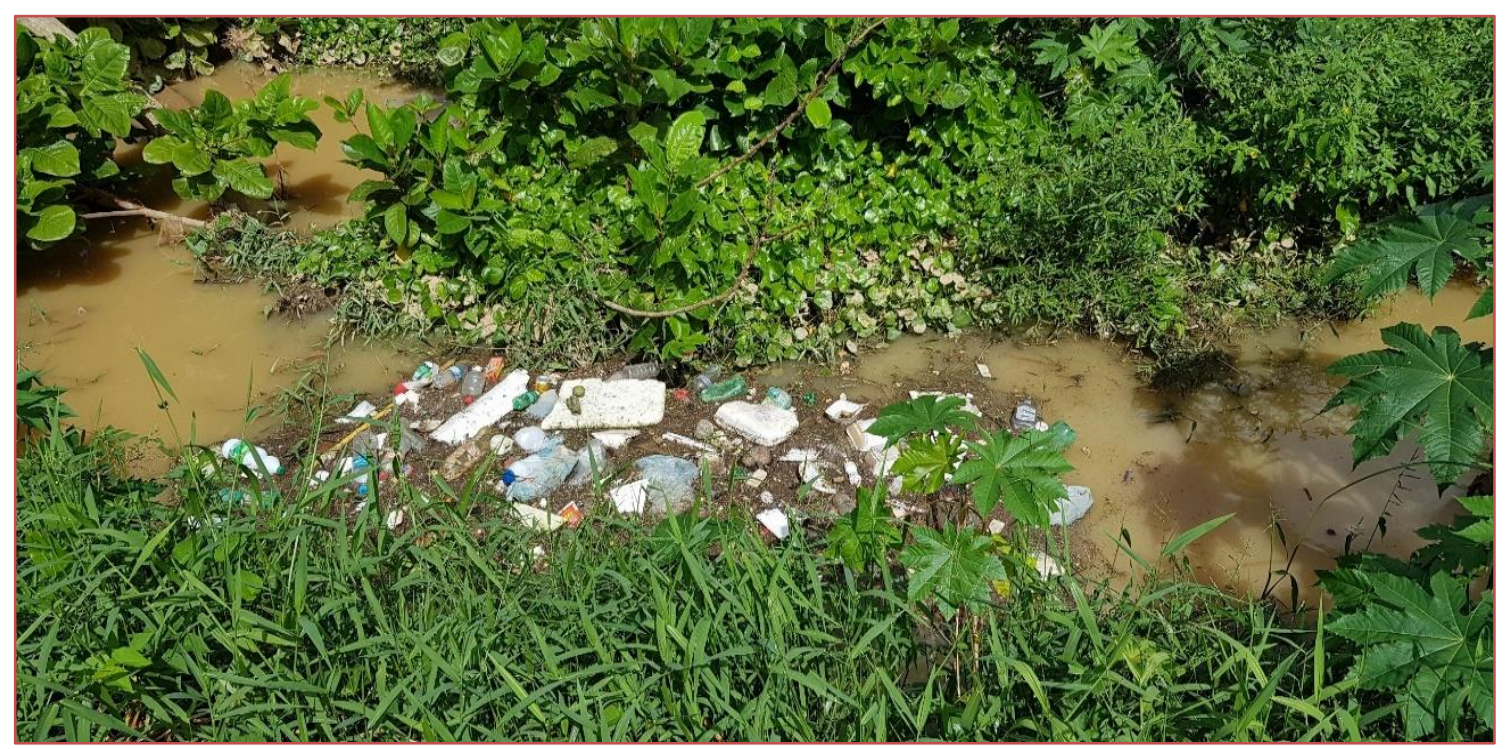

Fonte: autor, 2019.

Figura 8: Entrada de acesso à nascente, assoreamento por depósito de RCC no curso do riacho

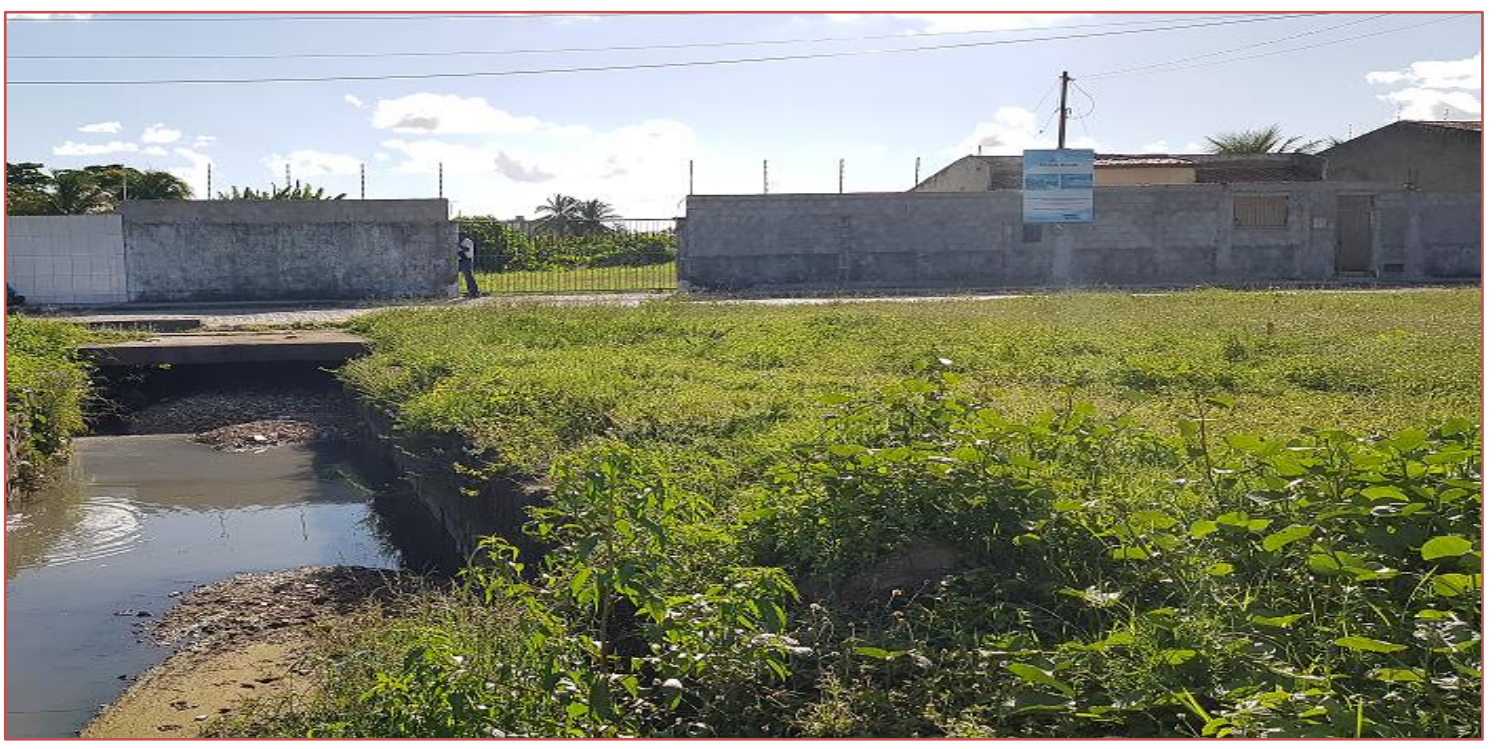

Fonte: autor, 2019.

A vegetação na posição próxima a Av. Canal até as margens é mínima, composta por algumas plantas invasivas, mamonas e árvores frutíferas (como bananeiras) que estão situadas nos quintais dos imóveis, que possuem acesso para a nascente. Mas a vegetação de predominância é da espécie Typha domingensis, popularmente conhecida como "taboa ou pau-de-lagoa" e está localizada ao fundo da nascente (Figura 9). 
Figura 9: Vegetação tipo "taboa ou pau-de-lagoa" em parte da nascente

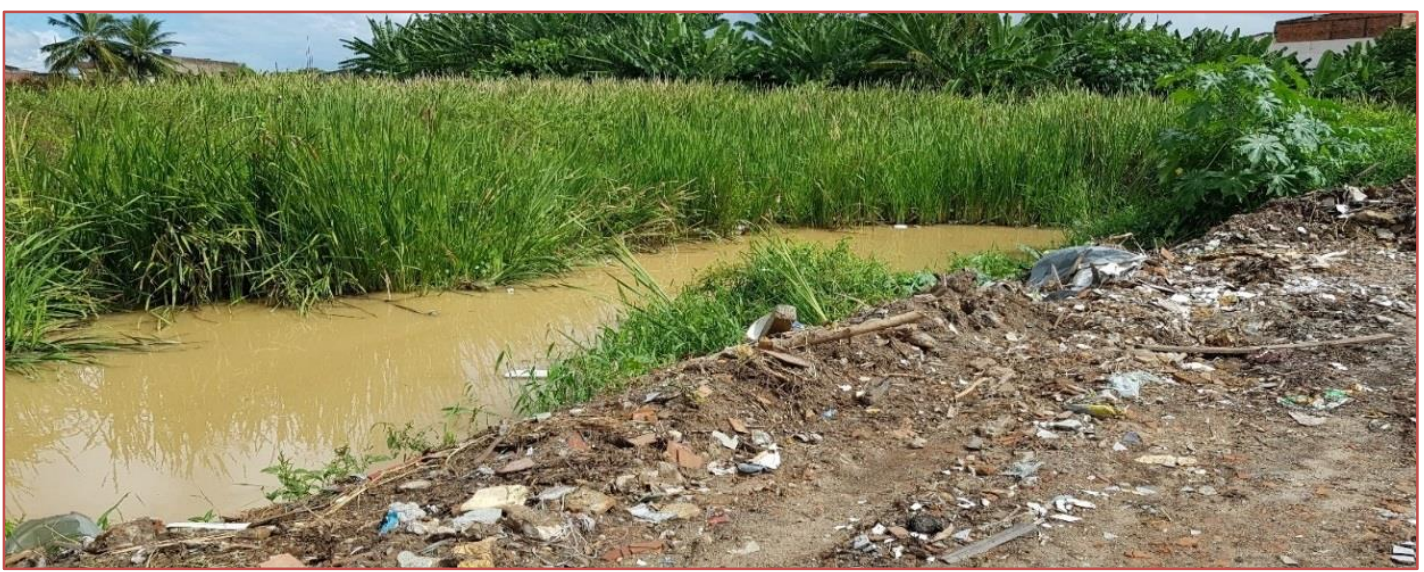

Fonte: autor, 2019.

A proteção da nascente é feita por muros (Figura 8), além de imóveis residenciais localizados a menos de 10 metros, o que dá acesso a nascente, significando interferência humana na APP - Área de Preservação Permanente (Figura 9).

Este fato contraria a Resolução no 303/2002 do CONAMA, em seu Art. 3o, inciso II, que determina um raio mínimo de $50 \mathrm{~m}$ destinados a área de preservação permanente, objetivando proteger as nascentes ou olhos d'água, ainda que seja intermitente (Figura 10).

Figura 10: Raio mínimo de 50m demonstrando o descumprimento da Resolução no 303/2002

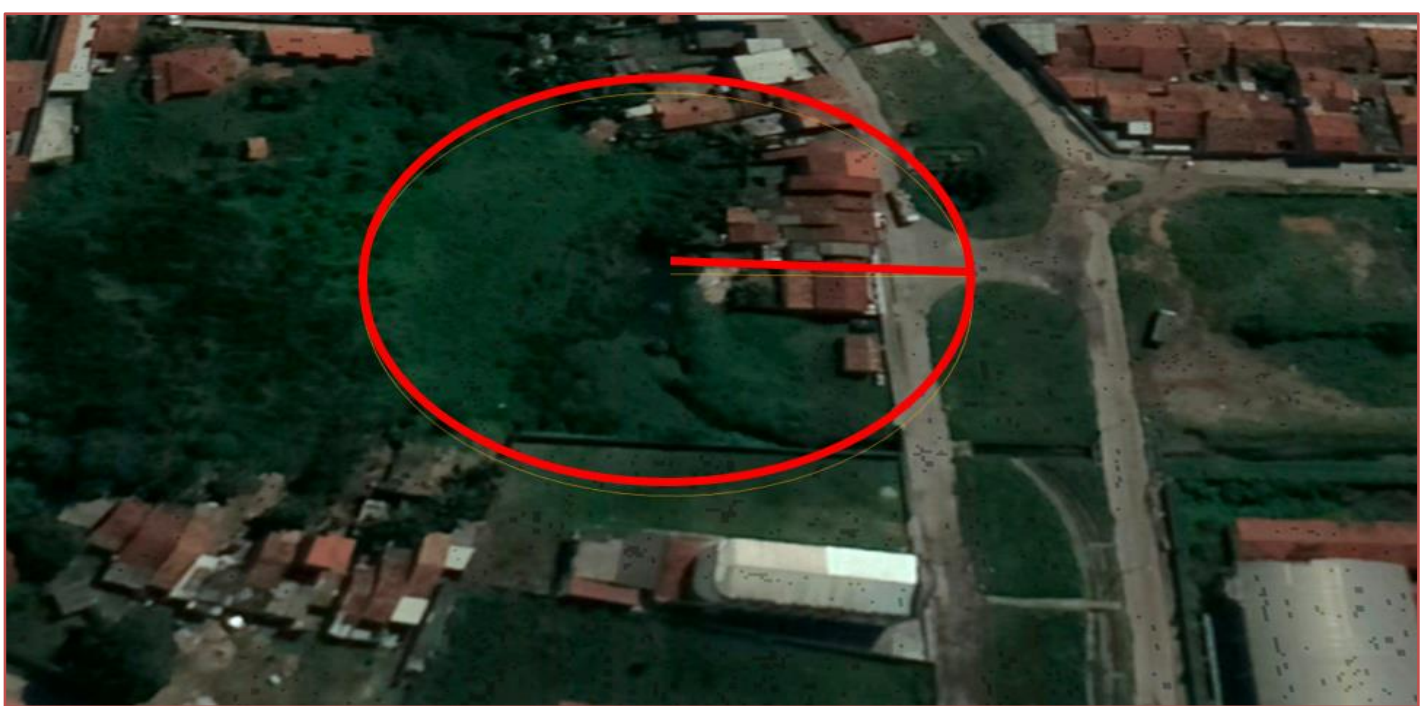

Fonte: Google Earth, 2018.

Conforme Figuras 11 e 12, no que diz respeito a drenagem de águas pluviais, torna-se evidente a falta de sarjetas e bueiros ao longo da via, o que acarreta em alagamentos em períodos de chuva, causando transtorno aos moradores. 
Figura 11: Lado esquerdo - Ausência de bueiros ao longo da Av. Canal

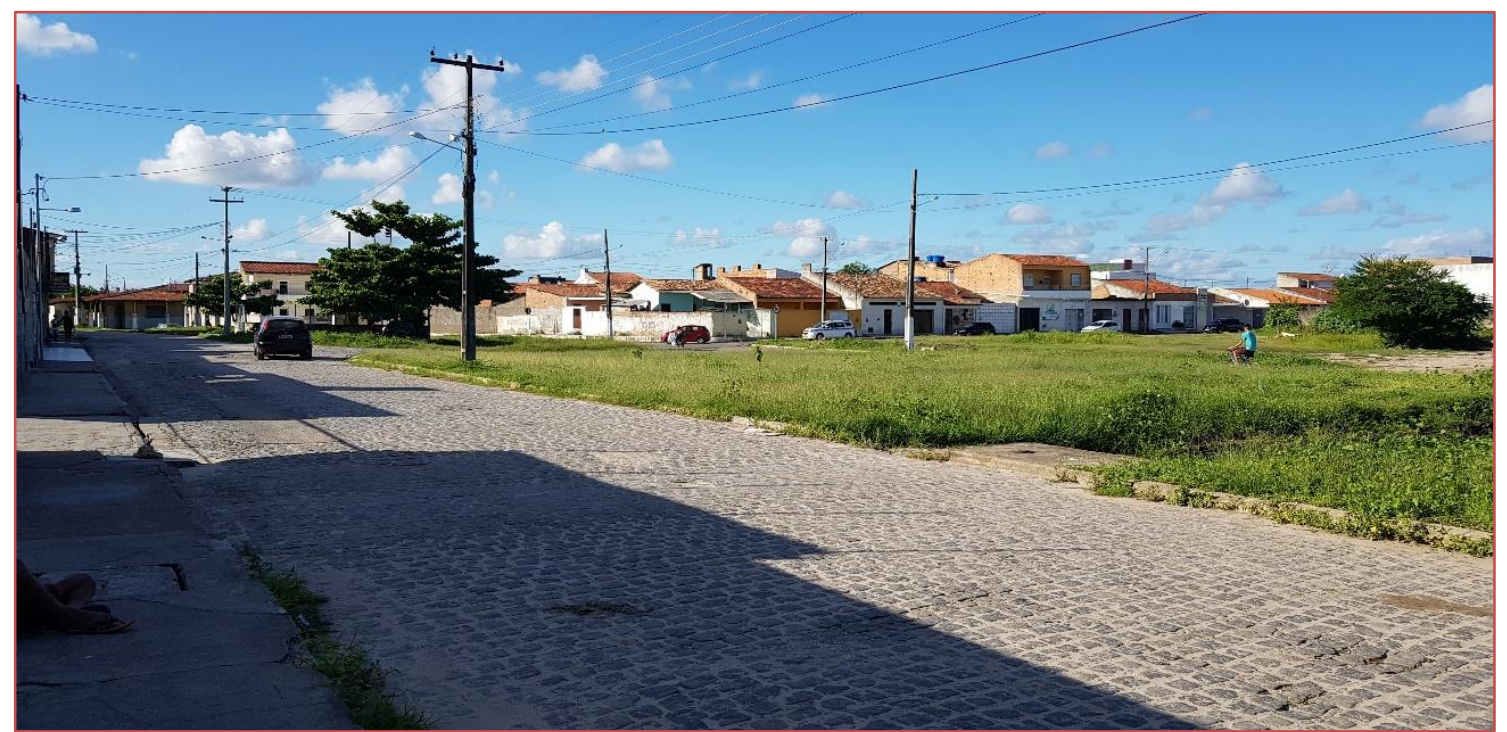

Fonte: autor, 2019.

Figura 12: Lado direito - Ausência de bueiros ao longo da Av. Canal

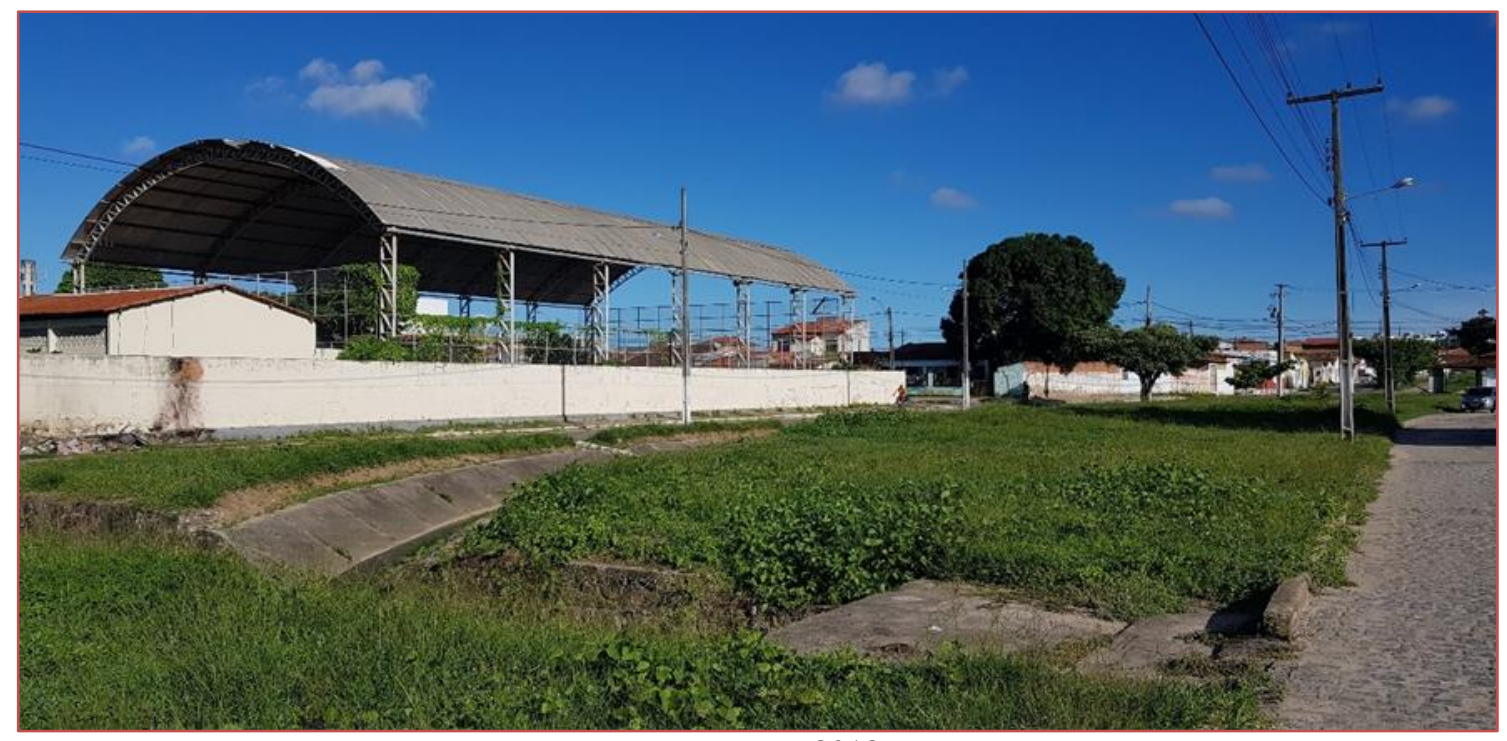

Fonte: autor, 2019.

Phillip (2005) relata que, no Brasil, um dos motivos das inundações urbanas está diretamente ligada a falta de moradia para a maioria da população que vive em estado de pobreza. 0 que vem gerando um grande número de favelas nas zonas periféricas dos grandes centros.

Outro fator relevante é a impermeabilização do solo juntamente com falta de planejamento da drenagem de águas pluviais, gerando um escoamento superficial, diminuindo assim, a infiltração e retenção da água que, quando o volume de escoamento ultrapassa a capacidade de escoamento, ocorrem as inundações.

\subsection{AVALIAÇÃO DA SUSTENTABILIDADE DOS SISTEMAS DE ESGOTAMENTO SANITÁRIO.}

A ausência de um sistema eficiente de coleta, disposição final e tratamento de esgoto doméstico pode causar graves impactos ao meio ambiente e a população. A correta destinação e tratamento destes reduz a ocorrência de diversas doenças para a população. 
Diversos equipamentos compõem a infraestrutura urbana e o saneamento básico é de fundamental importância para a manutenção da qualidade da saúde pública. Um fator que tende a reduzir a eficiência do abastecimento público, esgotamento sanitário, drenagem pluvial e gestão de resíduos sólidos é a existência de falhas em suas estruturas, além de aumentar o impacto no meio ambiente. Avaliando a sustentabilidade, pode-se aplicar os indicadores do sistema PEIR, conforme exposto na seção 2.2.

Os indicadores de Pressão podem ser conceituados como aqueles que geram pressão advindas das ações humanas sobre o meio ambiente. Na nascente objeto de estudo, puderam ser identificados cinco fatores que estão causando a degradação, são eles: o desague de águas residuais ao longo do curso do riacho, fator que deveria estar ocorrendo apenas para desague de águas pluviais; falta de estrutura para coleta e desague de águas pluviais; depósito de RCC no entorno da nascente e ao longo do curso do riacho; a retirada da vegetação local, que tem a função de proteção ao solo e à nascente e o aumento de construções no entorno da nascente.

Os indicadores de Estado são aqueles que expõem a atual situação do ambiente e sua evolução no tempo quanto as implicações quali-quantitativas. A atual situação é de completa degradação, poluição e desmatamento. Estes indicadores são reflexo dos indicadores anteriores, que vem ao longo do tempo alterando desfavoravelmente o contexto do local.

Os indicadores de Impacto demonstram os efeitos que a ações antrópicas vem causando e o quanto elas estão afetando o meio ambiente. Com desague de esgotamento sanitário, a água tem sua qualidade depreciada, além da contaminação do lençol freático, assim, não é possível ter uma fonte de consumo segura. Muitos litros de água contaminadas são desaguados em rios, isso afeta diretamente a vida aquática, fauna, flora e até mesmo a saúde humana, aumentando a possibilidade de contaminação e contração de doenças. A presença da cobertura vegetal é de suma importância. Ela é a defesa natural do solo e a falta dela deixa o solo vulnerável a ações da chuva, causando a erosão do terreno e possível assoreamento do riacho.

Os indicadores de Resposta são expostos como forma de encontrar possíveis soluções para os problemas encontrados na nascente. Por se tratar de um local habitado por pessoas de classe social menos assistida, uma solução que requer baixo custo de investimento é a fossa verde, sua aplicação se torna benéfica por haver plantação de bananeiras no local.

A ampliação da infraestrutura para coleta e destinação final de esgotamento sanitário também é uma possível solução, porém requer planejamento e investimento por parte dos gestores, juntamente com projeto e execução de obras para desague das águas pluviais, uma vez que atualmente está sendo lançado em conjunto com o esgoto doméstico.

Outras ações necessárias para complementar a solução para o desague de águas residuais são: a promoção da educação ambiental junto à população conscientizando-as quanto a importância das ligações sanitárias às redes coletoras; políticas públicas de implementação do plano municipal de saneamento básico de saneamento básico no Município de São Cristóvão; adoção de instrumentos de gestão da água e ambiental; reflorestamento e fiscalização da APP no entorno da nascente e fortalecimento da participação comunitária.

A exclusão social pode ser avaliada em diversos pontos da cidade a partir da infraestrutura existente. Em geral, as áreas mais abastadas possuem melhores condições, enquanto as periféricas acumulam apenas exclusão sócio ambiental, ocasionando diversos riscos ambientais devido a pressão nas áreas de preservação (JACOBI, 2006 apud DALTRO FILHO, 2010).

É preciso um esforço conjunto da humanidade para que se consigam as necessárias transformações. Para alcançar a sustentabilidade, portanto se faz necessário uma mudança de atitude. Os hábitos dos homens devem ser repensados. A tão sonhada sustentabilidade não depende só de poucos, mas sim de todos e a falta de conscientização nos faz crer que a sustentabilidade ainda é uma utopia, encontrando-se apenas no plano teórico (AFONSO, 2006 apud DALTRO FILHO e SOARES, 2010).

\section{CONSIDERAÇÕES FINAIS}

O estudo realizado buscou identificar as ações antrópicas ocorridas na nascente do riacho do Xoxota e, com isso, buscar possíveis soluções como forma de reduzir os impactos por ela sofrida.

Recomenda-se o aprofundamento das questões ambientais neste estudo levantadas, de modo que, as informações obtidas possam auxiliar à tomada de decisões por parte dos gestores municipais. 
A articulação destes gestores em conjunto com ações integradas, auxiliariam a população mudar sua percepção ambiental e trocar os hábitos inadequados por hábitos que serão benéficos a comunidade. Assim, poderiam atingir melhores indicadores ambientais, não só no entorno da nascente, mas também em toda São Cristóvão.

Assim, executar efetivamente as legislações vigentes, bem como revisá-las com o intuito de estar em frequente melhoria, são metas essenciais para uma boa gestão, evitando e mitigando os impactos que incidem diretamente sobre a nascente e o riacho do Xoxota e afetam diretamente a população local.

A frequente e correta aplicação da legislação, bem como a devida fiscalização, potencializará a conservação do ambiente urbano, proporcionando um ambiente equilibrado, fundamental à qualidade de vida dos moradores da área no entorno da nascente do riacho do Xoxota e demais transeuntes da área.

Concluindo, é notório que a nascente vem sofrendo com as ações antrópicas. Sendo assim, percebe-se que a curto prazo, se nenhuma ação efetiva com vistas a manutenção for implementada, a tendência será o aterro da nascente por completo, provocando prejuízos irreversíveis ao meio ambiente.

\section{REFERÊNCIAS}

[1] ARIZA, C. G.; ARAUJO NETO, M. D. Contribuições da geografia para avaliação de impactos ambientais em áreas urbanas, com o emprego da metodologia pressão - estado impacto - resposta (P.E.I.R.). Caminhos de Geografia, Uberlândia v. 11, n. 35, p. 128 - 139, 2010.

[2] BOMFIM, Luiz Fernando Costa, Projeto Cadastro da Infra-Estrutura Hídrica do Nordeste: Estado de Sergipe. Diagnóstico do Município São Cristóvão, Aracaju: CPRM, 2002.

[3] BRASIL. Resolução CONAMA no. 303, de 20 de março de 2002. Dispõe sobre parâmetros, definições e limites de Áreas de Preservação Permanente. Publicada no D.O.U. no 90 de 13 de maio de 2002.

[4] BRASIL. Resolução CONAMA no. 307, de 05 de julho de 2002. Estabelece diretrizes, critérios e procedimentos para a gestão dos resíduos da construção civil. Publicada no D.O.U. no 136 de 17 de julho de 2002.

[5] DALFOVO, M. S. et al. Métodos quantitativos e qualitativos: um resgate teórico. Revista Interdisciplinar Científica Aplicada, Blumenau, v. 2, n. 4, p. 01-13, Sem. II. 2008.

[6] DALTRO FILHO, José, Saneamento Ambiental: doença, saúde e o saneamento da água, São Cristóvão: Editora UFS; Aracaju, Fundação Oviedo Teixeira, 2006.

[7] DALTRO FILHO, José. II SOARES, Maria José Nascimento. Meio ambiente, sustentabilidade e saneamento: relatos sergipanos / José Daltro Filho, Maria José Nascimento Soares (Organizadores). - Porto Alegre: Redes Editora, 2010.

[8] FERREIRA, R. A., et al. Nascentes Da Sub-Bacia Hidrográfica Do Rio Poxim, Estado De Sergipe: Da Degradação À Restauração. Revista Árvore, Viçosa-MG, v.35, n.2, p.265-277, 2011.

[9] GOMES, Priscila Moreira; MELO, Celine de; VALE, Vagner Santiago do. Avaliação dos impactos ambientais em nascentes na cidade de Uberlandia-MG: Análise Macroscópica. Sociedade \& Natureza, Uberlândia, v. 32, n. 17, p.103120, 20 jun. 2005.

[10] GIL, Antonio Carlos, Métodos e técnicas de pesquisa social, 6 ed, São Paulo: Atlas, 2008KEMERICH; RITTER; BORBA, 2014.

[11] KEMERICH, Pedro Daniel da Cunha; RITTER, Luciana Gregory; BORBA, Wilian Fernando. Indicadores de sustentabilidade ambiental: métodos e aplicações Revista Monografias Ambientais - REMOA, UFSM, Santa Maria V. 13, N.5 p. 3723, 2014.

[12] LAKATOS, Eva Maria, Fundamentos de metodologia científica, 5 ed, São Paulo: Atlas, 2003.

[13] PHILIPPI, Arlindo Jr, Saneamento, Saúde e Ambiente: Fundamentos para um desenvolvimento Sustentável, Coleção Ambiental, Editora Manole, 1 Ed., 2005

[14] População estimada: IBGE, Diretoria de Pesquisas, Coordenação de População e Indicadores Sociais, Estimativas da população residente com data de referência 10 de julho de 2018.

[15] PRODANOV, Cleber Cristiano, Metodologia do trabalho científico: métodos e técnicas da pesquisa e do trabalho acadêmico, 2 ed., Novo Hamburgo: Freevale, 2013.

[16] SANTOS, Lidiane Alonso Paixão dos. Análise e gestão de corpos hídricos urbanos na bacia hidrográfica do alto Tietê.2016. 224 f. Dissertação (Mestrado) - Curso de Ambiente, Saúde e Sustentabilidade, Universidade de São Paulo, São Paulo, 2017. 
[17] SÃO CRISTÓVÃO. PREFEITURA MUNICIPAL DE SÃO CRISTÓVÃO. (Org.). Prefeitura realiza limpeza no riacho da Xoxota. 2018. Disponível em: <https://www.saocristovao.se.gov.br/page.php?sa=0\&pgref=noticiadetalhe\&cod=810 >. Acesso em: 29 mar. 2019.

[18] SEMARH. Atlas Digital de Recursos Hídricos de Sergipe, 2012. 


\section{Capítulo 8}

Patologia em revestimento de argamassa em residências unifamiliar provenientes dos efeitos da umidade

\section{Gladston Nogueira Matos}

\section{Giseli Barbosa de Lima}

Resumo: A ocorrência de manifestações patológicas nas edificações é um fator preocupante, pois estes problemas interferem diretamente na vida útil das construções, por comprometer a funcionalidade dos elementos construtivos em que se instalam. Estas são provenientes do uso de materiais de forma inadequada, mão-de-obra desqualificada e falhas de projetos. 0 presente trabalho tem por objetivo fazer uma análise das manifestações patológicas no revestimento de argamassa provenientes da umidade, em residências unifamiliares no bairro Conjunto Jardim do município de Nossa Senhora do Socorro, Sergipe. A metodologia utilizada foi o estudo de caso de forma qualitativa e exploratória. Para concretização deste estudo, foram realizadas inspeções com o intuito de fazer a identificação das manifestações patológicas e confecção de plantas, em três residências selecionadas para tal. Com os resultados obtidos, foram verificados a presença de diversos pontos de aflorações das manifestações patológicas ocasionadas por umidade nos revestimentos de argamassa das residências analisadas, estabelecida hipóteses de atuação do agente vinculante, bem como exposto os procedimentos para fazer a correção das mesmas.

Palavras-chave: Patologia. Revestimento. Umidade. 


\section{INTRODUÇÃO}

Desde os primórdios o homem tem a técnica da construção e essa prática se difunde de geração para geração. Com o passar do tempo, o homem vem buscando cada vez mais aprimorar suas técnicas construtivas, na busca de conceber estruturas que garantam mais conforto e segurança para os usuários.

Com o desenvolvimento de forma acelerada da construção civil para suprir a procura crescente por edificações, começaram a surgir muitas estruturas com desempenho insatisfatório, provenientes do uso de materiais de forma inadequada, erros na concepção de projetos, uso de mão-de-obra desqualificada, a falta de fiscalização, enfim são diversos os motivos contribuintes para a deterioração das estruturas. A partir da ocorrência desses problemas, buscou-se aprimorar os estudos para identificar as origens, os tipos de manifestações, os mecanismos de ocorrência dos problemas e suas consequências; a esse estudo dar-se o nome de Patologia das Estruturas.

As manifestações patológicas são as principais causas para ocorrência dos problemas que interferem na vida útil das edificações. Dentre as patologias, destacam-se as que ocorrem por umidade, sendo estas o objeto de estudo deste trabalho.

Conforme o dicionário Aurélio (2010), a palavra Umidade, é "qualidade ou estado de úmido, estado de molhado ou um pouco molhado, relento da noite". Associando com as patologias, no contexto para engenharia a umidade é a "qualidade ou estado úmido ou ligeiramente molhado" (KLEIN, 1999).

Este trabalho tem como objetivo, o estudo das manifestações patológicas no revestimento de argamassa provenientes da umidade, em residências unifamiliares no bairro Conjunto Jardim do município de Nossa Senhora do Socorro, Sergipe. Esse estudo foi realizado a partir da abordagem de informações que contribuam para o entendimento e a caracterização dos problemas, bem como definir uma forma conveniente de corrigi-las.

\section{METODOLOGIA}

A metodologia adotada para realização foi o de estudo de caso, tendo como referência para o seu desenvolvimento o método de Lichtenstein (1986), o qual possui metodologia qualitativa e exploratória.

De acordo com Gerhardt e Silveira (2009) a metodologia qualitativa objetiva a realização do estudo aprofundado, não preocupando-se em quantificar, apresentando assim uma metodologia própria de desenvolvimento. Já a metodologia exploratória busca no seu desenvolvimento a análise de semelhança ao problema abordado, para obtenção de uma melhor compreensão e análise, onde pode ser realizada por meio de pesquisa bibliográfica e estudo de caso.

As residências tomadas como referência para o desenvolvimento do estudo estão localizas no bairro Conjunto Jardim no município de Nossa Senhora do Socorro, localizado na Região Metropolitana de Aracaju (Figura 1). Possui um clima tropical quente e úmido, com um a três meses secos, além de moderado excesso de inverno caracterizado por um período de chuva entre os meses de março a agosto. A precipitação anual média é de 1.689,0 mm/ano e temperatura de 25,2 C (CLIMATE, 2018). 
Figura 1: Mapa com a localização da cidade de Nossa Senhora do Socorro, com destaque na localização da área de estudo

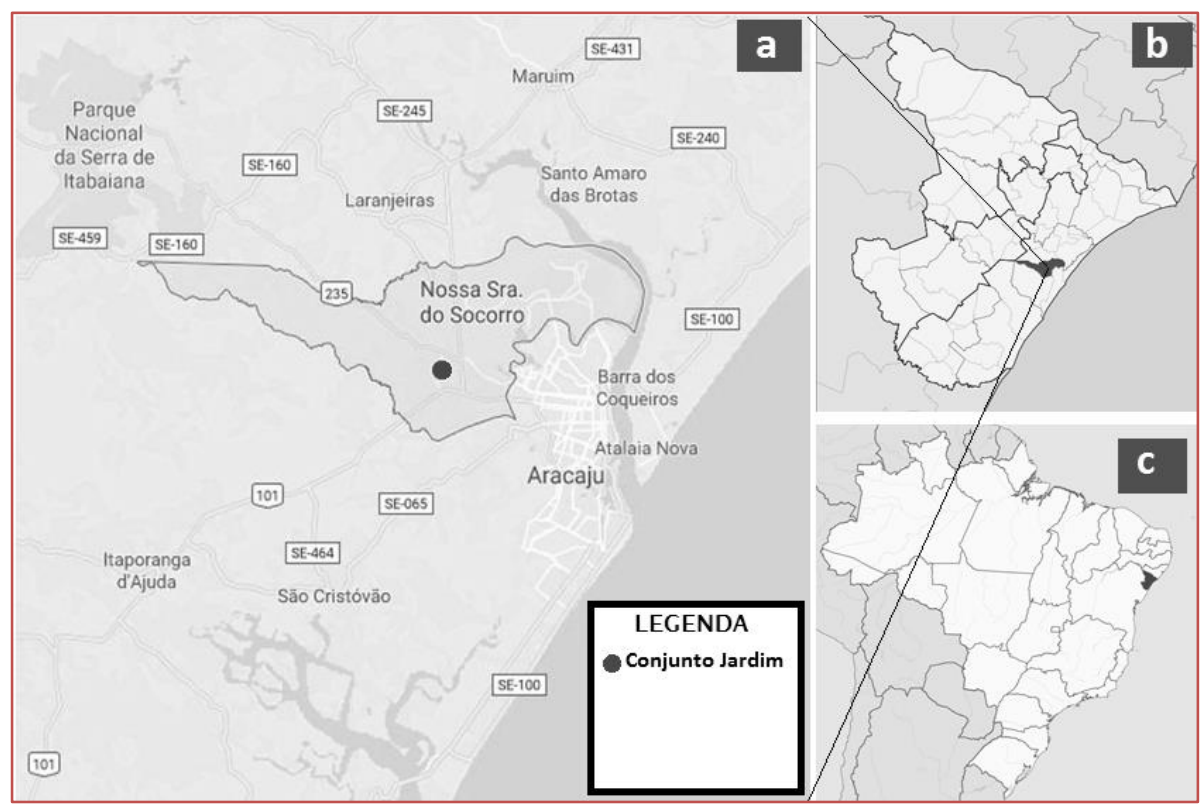

Fonte: (a) Google Maps (2018); (b) e (c) Mapas Blog (2018).

O método adotado neste presente estudo caracteriza-se como uma pesquisa qualitativa que visa a análise e identificação dos problemas patológicos ocasionados pela umidade no revestimento de argamassa de residências por meio de coleta de dados obtidos através de visitas in loco e referenciadas a partir de pesquisas bibliográficas.

As etapas desenvolvidas estão apresentadas na Figura 2.

Figura 2: Representação das etapas do estudo

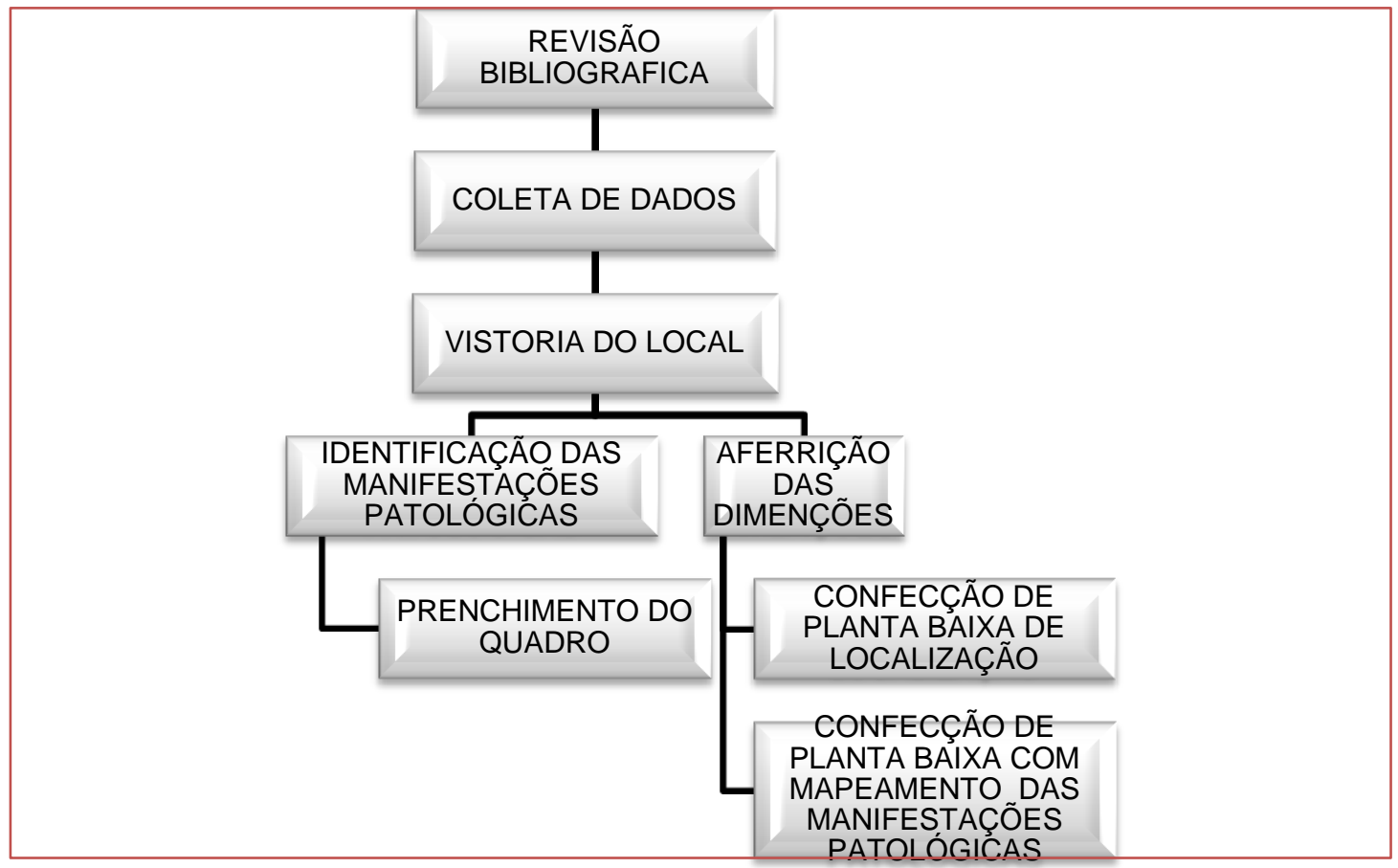

Fonte: Autor (2018). 
Conforme apresentado na Figura 2, na fase inicial do estudo ocorreu uma busca por informações que pudesse fundamentar e auxiliar na compreensão do estudo a ser realizado, estas informações foram obtidas através de pesquisa bibliográfica utilizando como fonte artigos científicos, literatura de livros técnicos, revistas técnicas, dissertações e materiais disponíveis na internet.

Após a revisão bibliográfica foi efetuado a coleta de dados, sendo que para estas foram realizadas visitas in loco nas residências selecionadas para o estudo, com o intuito de analisar o tipo e a ocorrência das manifestações patológicas no revestimento argamassado provenientes da umidade. Segundo De Milito (2009), tais manifestações patológicas provenientes da umidade manifestam-se por manchas de umidade, acompanhadas ou não pela formação de eflorescência, desagregação do revestimento com pulverulência, desagregação do revestimento com empolamento, ou formação de bolor em pontos onde não há incidência de sol.

Para identificação dos tipos de patologias encontradas tomou-se por base conceitos e características definidas na Tabela 1.

Tabela 1 - Definições dos tipos de manifestações patológicas no revestimento de argamassa provenientes dos efeitos da umidade

\begin{tabular}{|c|c|c|}
\hline $\begin{array}{l}\text { MANIFESTAÇÃO } \\
\text { PATOLÓGICA }\end{array}$ & AUTOR & DEFINIÇÃO \\
\hline Eflorescência & Bauer (1997) & $\begin{array}{l}\text { Agregações salinas, que se instalam na superfície de alvenarias ou } \\
\text { revestimentos, caracterizados pelo surgimento de manchas de umidade e } \\
\text { acúmulo de material pulverulento de coloração esbranquiçada sobre a } \\
\text { superfície do revestimento argamassado. }\end{array}$ \\
\hline Mofo Ou Bolor & $\begin{array}{l}\text { Alucci et al., } \\
\quad(1988)\end{array}$ & $\begin{array}{l}\text { É uma alteração de fácil observação na superfície dos materiais, sendo uma } \\
\text { consequência do desenvolvimento de microrganismos pertencentes ao } \\
\text { grupo dos fungos. }\end{array}$ \\
\hline $\begin{array}{l}\text { Desagregação } \\
\text { Com } \\
\text { Pulverulência }\end{array}$ & Segat (2005) & $\begin{array}{l}\text { Caracteriza-se por uma argamassa frágil, cujo sinal mais frequente de } \\
\text { pulverulência é a desintegração da argamassa ao ser pressionada } \\
\text { manualmente, normalmente, camada de tinta destaca-se juntamente com a } \\
\text { argamassa que se desagrega com facilidade. }\end{array}$ \\
\hline $\begin{array}{l}\text { Desagregação } \\
\text { Com } \\
\text { Empolamento }\end{array}$ & Cincotto (1988) & $\begin{array}{l}\text { Ocorre quando o reboco descola do emboço, formando bolhas que } \\
\text { aumentam drasticamente de tamanho. }\end{array}$ \\
\hline
\end{tabular}

Fonte: autor (2018).

A partir das definições supracitadas, o passo seguinte executado foi à identificação dos tipos de manifestações patológicas e a possível origem das umidades que acarretam o surgimento de tais manifestações patológicas. Para tal foi feito o preenchimento dos quadros que relaciona os tipos de manifestações patológicas existente, por ambiente das residências.

Após esta etapa foram aferidas as dimensões dos ambientes bem como os desníveis entre as residências vizinhas para assim confeccionar duas plantas, sendo uma de locação com demonstração dos desníveis e a planta baixa da residência com mapeamento dos pontos de incidência das manifestações patológicas nas residências.

A quantidade de residências tomadas como amostra para a realização da pesquisa foi determinada de maneira a proporcionar uma análise estatística dos resultados. Desta forma, adotaram-se três residências como referência para o estudo sendo estas nomeadas como residência " $A$ ", residência "B" e residência " $C$ ". Todas as unidades residenciais estão providas de infraestrutura de esgotamento sanitário, água potável e energia elétrica.

As visitas nas residências "A" e "B" foram efetuadas no dia 28/08/2018 onde foram coletados os dados necessários em cada residência para a realização do estudo. Já a visita na residência "C" foi efetuada no dia 30/08/2018 onde foram coletados os dados necessários na residência para compor e estruturar a realização do estudo.

Na presente pesquisa foram utilizados os seguintes materiais e equipamentos: 
- $\quad$ Prancheta, caneta e papel para anotação dos dados, medidas e confecção do esboço das plantas das residências;

- $\quad$ Fita métrica metálica para a aferição dos desníveis e das dimensões dos cômodos da residência e a propagação das manifestações patológicas;

- Computador para armazenamento das informações e processamento dos dados;

Com a realização das visitas nas residências tomadas como referência para o estudo foi analisada a ocorrência e tipologia das manifestações patológicas em diversos cômodos, bem como a presença da umidade visível nos locais de incidência dos mesmos. Os resultados das análises realizadas foram inseridos em quadros.

\section{RESULTADOS E DISCUSSÃO}

\subsection{CARACTERÍSTICAS DA INSPEÇÃO DAS RESIDÊNCIAS}

Foram realizadas as visitas nas residências selecionadas para o estudo, sendo as mesmas acompanhadas pelos seus respectivos proprietários. Nesta fase, foi devidamente verificado cada ambiente das residências, sendo realizado a identificação das manifestações patológicas existentes bem como a alimentação dos quadros que relaciona o tipo de manifestação patológica existente por cômodo.

Outro procedimento que foi englobado nesta fase foi à aferição das dimensões dos cômodos das residências para confecção das plantas baixas, uma de locação com demonstração dos desníveis e outra com mapeamento dos pontos de incidência das manifestações patológicas nas residências.

\subsubsection{RESIDÊNCIA “A”}

A unidade residencial "A" possui uma área construída de 120,00 m2, divididos em garagem, sala, banheiro, dois quartos, cozinha e área de serviço. Possui um sistema construtivo convencional com alvenaria estrutural de blocos cerâmicos, sendo seu revestimento feito com argamassa convencional. Possui um sistema de cobertura convencional de telha colonial de cerâmica.

Através da realização da vistoria na residência " $A$ " foram devidamente verificados e identificados os pontos de incidência das manifestações patológicas bem como seu tipo (Tabela 2).

Tabela 2 - Representação dos tipos de manifestações patológicas por cômodo da residência "A"

\begin{tabular}{l|c|c|c|c}
\multirow{2}{*}{ MANIFESTAÇÕES PATÓLOGICAS } & \multicolumn{5}{c}{ CÔMODOS DA RESIDÊNCIA } \\
\cline { 2 - 4 } Eflorescência & Garagem & Sala & Quarto 1 & Quarto 2 \\
\hline Mofo ou Bolor & & $\mathrm{X}$ & & $\mathrm{X}$ \\
\hline Desagregação com Pulverulência & $\mathrm{X}$ & $\mathrm{X}$ & & $\mathrm{X}$ \\
\hline Desagregação com Empolamento & & $\mathrm{X}$ & $\mathrm{X}$ & \\
\hline
\end{tabular}

Fonte: autor (2018).

Com o intuito de demonstrar com maior clareza os dados obtidos para análise, foram elaboradas duas plantas, uma de locação com identificação dos desníveis (Figura 3) e uma planta baixa da residência com mapeamento dos pontos de incidência das manifestações patológicas na residência através de cores conforme legenda (Figura 4). 
Figura 3: Localização da residência com relação à quadra e desnível entre as residências vizinhas (sem escala)

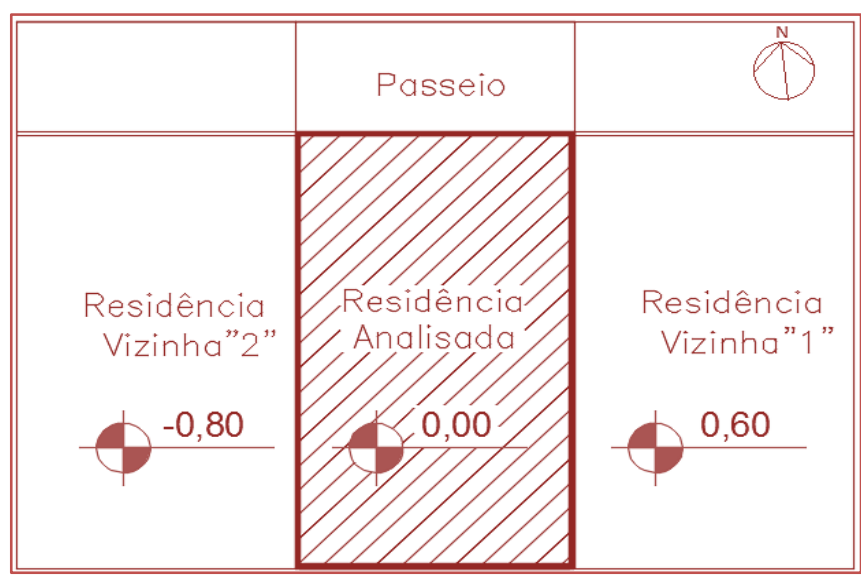

Fonte: autor (2018).

Como demostrado na Figura 3, a residência "A" está localizada $0,60 \mathrm{~m}$ abaixo da residência vizinha "1" situada à margem direita, caracterizando assim o elemento construtivo que faz a divisão entre as residências como uma estrutura enterrada. Segundo Righi et al. (2009), esta enquadra-se como tal, pelo fato da ocorrência do contato direto da alvenaria com o solo fazendo a contenção deste. Ressalta ainda que no caso da ausência de um tratamento eficaz contra a umidade, estas condições possibilitam um meio favorável para a ocorrência de infiltrações pelos capilares do material em contato.

Figura 4: Planta da residência com mapeamento dos pontos de incidência das manifestações patológicas

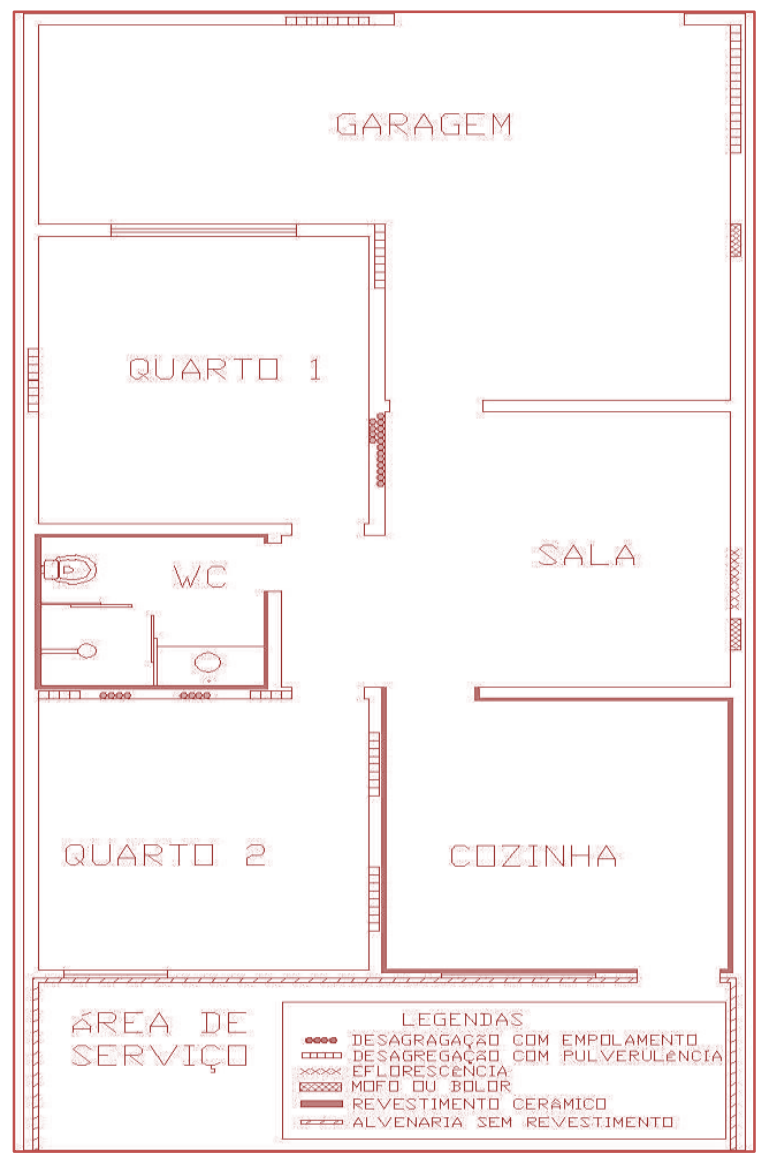

Fonte: autor (2018). 
Fazendo uma análise da Figura 4 verifica-se que em quase toda sua totalidade da residência foram identificadas manifestações patológicas nos seus cômodos. Tais manifestações patológicas foram caracterizadas como: eflorescência, mofo (bolor), desagregação do revestimento com empolamento e desagregação com pulverulência. Foi constatado também a presença de umidade nos pontos de incidência das manifestações patológicas sendo estes localizados na parte inferior do revestimento de argamassa.

Outro fator que pode ser notado é que nos cômodos banheiro, cozinha e área de serviço não foram possíveis identificar a incidência de manifestações patológicas, sendo imperceptível pelo fato de o banheiro e cozinha possuírem revestimento cerâmico e na área de serviço pela inexistência de revestimento argamassado.

\subsubsection{RESIDÊNCIA "B"}

A unidade residencial "B" possui uma área construída de 105,00 m2, divididos em área comercial, varanda, sala, quarto 1, quarto 2, cozinha, banheiro 1, banheiro 2, depósito e área de serviço. Possui um sistema construtivo convencional com alvenaria estrutural de blocos cerâmicos, sendo seu revestimento feito com argamassa convencional. Possui um sistema de cobertura convencional de telha colonial de cerâmica.

Através da realização da vistoria na residência "B" foram devidamente verificados e identificados os pontos de incidência das manifestações patológicas bem como seu tipo (Tabela 3). Nos pontos identificados foi constatado a presença de umidade.

Tabela 3 - Representação dos tipos de manifestações patológicas por cômodo da residência "B"

\begin{tabular}{|c|c|c|c|c|c|c|c|}
\hline \multirow[b]{2}{*}{$\begin{array}{c}\text { MANIFESTAÇÕES } \\
\text { PATOLÓGICAS }\end{array}$} & \multicolumn{7}{|c|}{ CÔMODOS DA RESIDÊNCIA } \\
\hline & $\begin{array}{c}\text { Área } \\
\text { Comercial }\end{array}$ & Varanda & Sala & Quarto 1 & Quarto 2 & Deposito & $\begin{array}{l}\text { Área de } \\
\text { Serviço }\end{array}$ \\
\hline Eflorescência & & & & & & & \\
\hline Mofo ou Bolor & $\mathrm{X}$ & $\mathrm{X}$ & $\mathrm{X}$ & & $\mathrm{X}$ & $\mathrm{X}$ & $\mathrm{X}$ \\
\hline $\begin{array}{l}\text { Desagregação com } \\
\text { Pulverulência }\end{array}$ & $\mathrm{X}$ & $\mathrm{X}$ & $\mathrm{X}$ & & $\mathrm{X}$ & $\mathrm{X}$ & $\mathrm{X}$ \\
\hline $\begin{array}{l}\text { Desagregação com } \\
\text { Empolamento }\end{array}$ & $\mathrm{X}$ & $\mathrm{X}$ & & $\mathrm{X}$ & $\mathrm{X}$ & $\mathrm{X}$ & $\mathrm{X}$ \\
\hline
\end{tabular}

Com o intuito de demonstrar com maior clareza os dados obtidos para análise, foram elaboradas duas plantas baixas, uma de locação com demonstração dos desníveis e outra com mapeamento dos pontos de incidência das manifestações patológicas na residência (Figura 5) e (Figura 6) respectivamente.

Figura 5: Localização da residência com relação à quadra e desnível entre as residências vizinhas (sem escala)

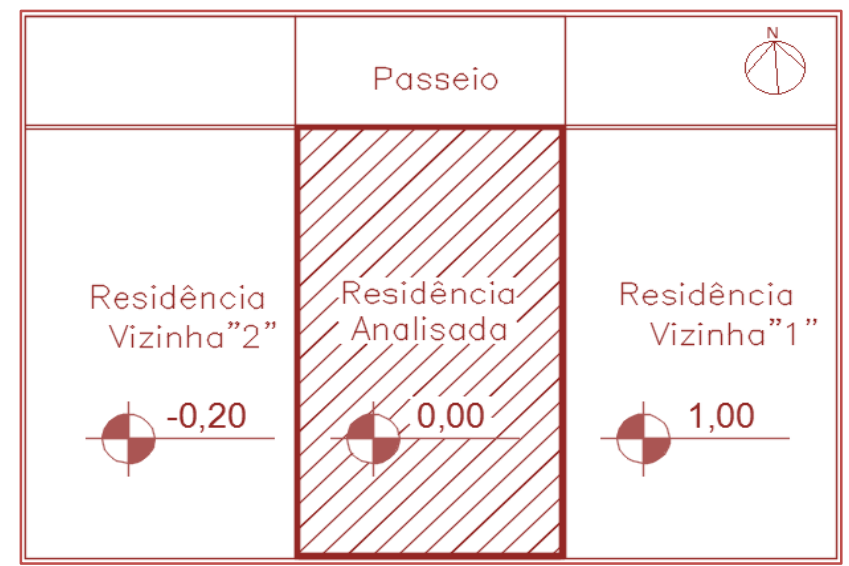

Fonte: autor (2018). 
Como demostrado na Figura 5, a residência "b" está localizada 1,00 m abaixo da residência vizinha "1" situada à margem direita, caracterizando assim o elemento construtivo que faz a divisão entre as residências como uma estrutura enterrada. Segundo Righi et al. (2009), esta enquadra-se como tal, pelo fato da ocorrência do contato direto da alvenaria com o solo fazendo a contenção deste. No caso da ausência de um tratamento eficaz contra a umidade estas condições possibilita um meio favorável para a ocorrência de infiltrações pelos capilares do material em contato com o solo.

Figura 6: Planta Baixa da residência "B" com mapeamento dos pontos de incidência das manifestações patológicas

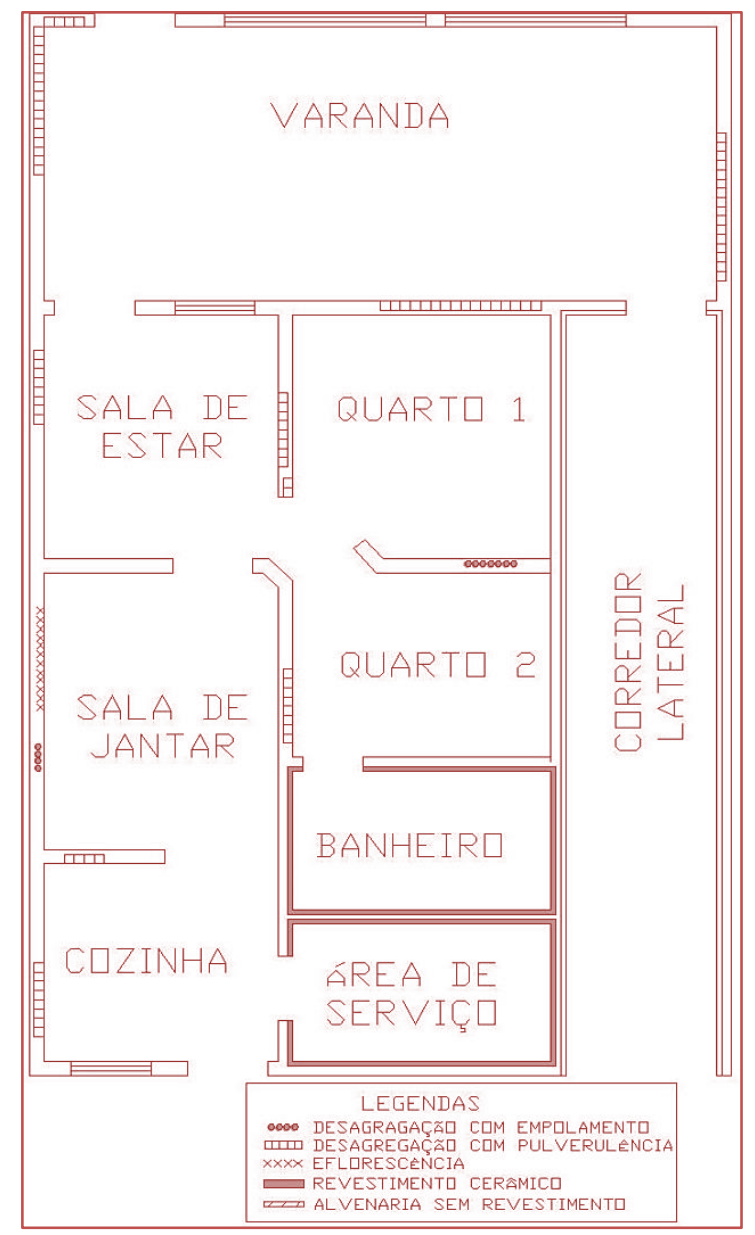

Fonte: Autor (2018).

Fazendo uma análise da Figura 6 observa-se que na maioria dos ambientes da residência foram identificadas a presença de manifestações patológicas, exceto nos ambientes banheiro1, banheiro2 e cozinha por estes possuírem revestimento cerâmico, impossibilitando assim a visualização do revestimento argamassado.

Outro fator que é possível ser analisado é a inexistência de manifestações de eflorescência na residência, sendo as manifestações patológicas identificadas foram caracterizadas como: mofo (bolor), desagregação do revestimento com empolamento e desagregação com pulverulência. Tais manifestações patológicas foram localizadas em maior concentração na parte inferior do revestimento de argamassa, sendo encontradas em alguns pontos da parte superior a incidência de mofo (bolor).

\subsubsection{RESIDÊNCIA “C”}

A unidade residencial “C” possui uma área construída de 85,00 m2, divididos em varanda, sala de estar, sala de jantar, quarto 1 , quarto 2, cozinha, banheiro e área de serviço. Possui um sistema construtivo 
convencional com alvenaria estrutural de blocos cerâmicos, sendo seu revestimento feito com argamassa convencional. Possui um sistema de cobertura convencional de telha colonial de cerâmica.

Através da realização da vistoria na residência "C" foram devidamente verificados e identificados os pontos de incidência das manifestações patológicas bem como seu tipo (Tabela 4). Constatou-se também a presença de umidade nos locais de incidência das manifestações patológicas.

Tabela 4 - Representação dos tipos de manifestações patológicas por cômodo da residência "C"

\begin{tabular}{|c|c|c|c|c|c|c|}
\hline \multirow{2}{*}{$\begin{array}{l}\text { MANIFESTAÇÕES } \\
\text { PATOLÓGICAS }\end{array}$} & \multicolumn{6}{|c|}{ CÔMODOS DA RESIDÊNCIA } \\
\hline & Varanda & $\begin{array}{l}\text { Sala de } \\
\text { Estar }\end{array}$ & $\begin{array}{l}\text { Sala de } \\
\text { Jantar }\end{array}$ & Quarto 1 & Quarto 2 & Cozinha \\
\hline Eflorescência & & & $\mathrm{X}$ & & & \\
\hline Mofo ou Bolor & & & & & & \\
\hline $\begin{array}{l}\text { Desagregação com } \\
\text { Pulverulência }\end{array}$ & $\mathrm{X}$ & $\mathrm{X}$ & & $\mathrm{X}$ & $\mathrm{X}$ & $\mathrm{X}$ \\
\hline $\begin{array}{l}\text { Desagregação com } \\
\text { Empolamento }\end{array}$ & $\mathrm{X}$ & & $\mathrm{X}$ & $\mathrm{X}$ & & \\
\hline
\end{tabular}

Fonte: autor (2018).

Com o intuito de demonstrar com maior clareza os dados obtidos para análise, foram elaboradas duas plantas baixas, uma de locação com demonstração dos desníveis e outra com mapeamento dos pontos de incidência das manifestações patológicas na residência (Figura 7) e (Figura 8) respectivamente.

Figura 7: Localização da residência com relação à quadra e desnível entre as residências vizinhas (sem escala)

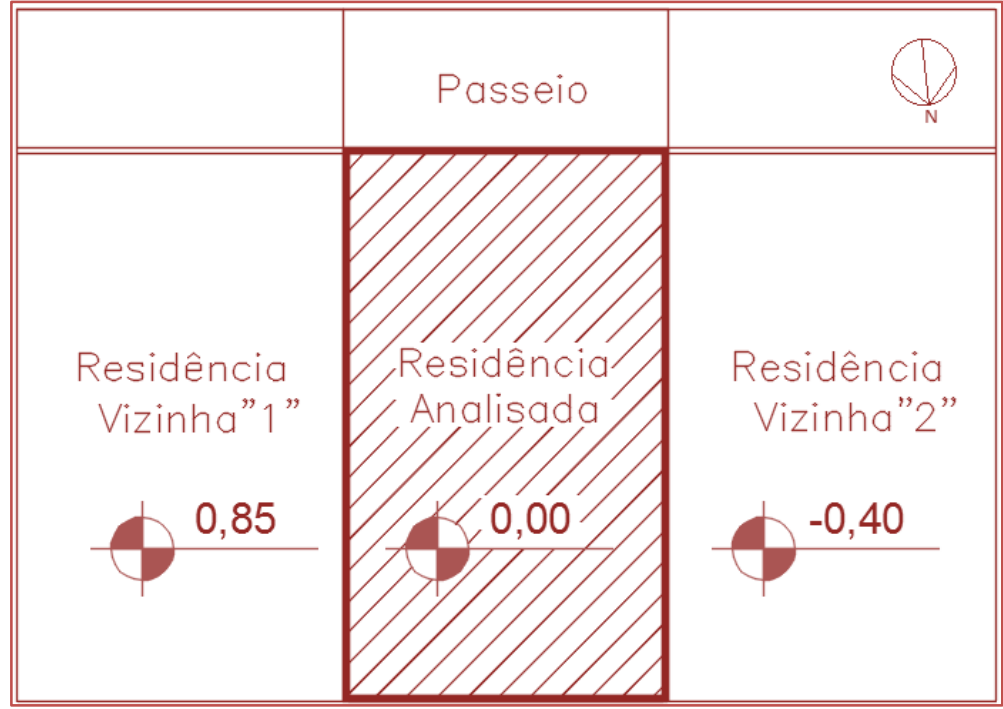

Fonte: autor (2018).

Como demostrado na Figura 7, a residência "C" está localizada 0,85 m abaixo da residência vizinha "1" situada à margem esquerda, caracterizando assim o elemento construtivo que faz a divisão entre as residências como uma estrutura enterrada. Segundo Righi et al. (2009), esta enquadra-se como tal, pelo fato da ocorrência do contato direto da alvenaria com o solo fazendo a contenção deste. No caso da ausência de um tratamento eficaz contra a umidade estas condições possibilita um meio favorável para a ocorrência de infiltrações pelos capilares do material em contato com o solo. 
Figura 8: Planta Baixa da residência "C" com mapeamento dos pontos de incidência das manifestações patológicas

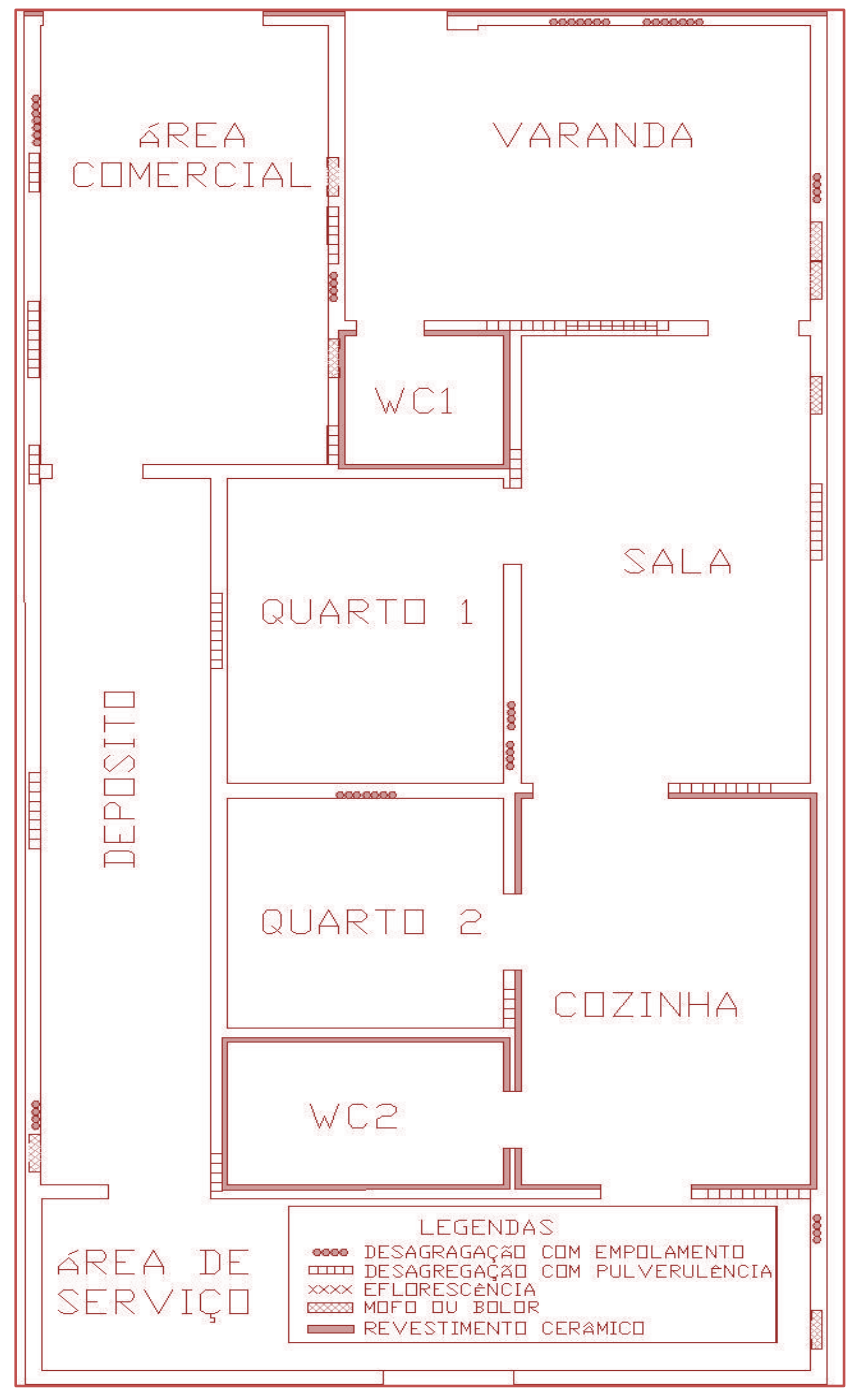

Fonte: Autor (2018).

Fazendo uma análise da Figura 8 verifica-se que em quase toda sua totalidade da residência foram identificadas manifestações patológicas nos seus cômodos. Tais manifestações patológicas foram caracterizadas como: eflorescência, desagregação do revestimento com empolamento e desagregação com pulverulência. É perceptível a inexistência da manifestação patológica mofo ou bolor na residência. Outro ponto relevante é que tais manifestações patológicas foram localizadas na parte inferior do revestimento de argamassa.

Outro fator que pode ser notado é que nos ambientes banheiro, área de serviço e corredor lateral não foram possíveis identificar a incidência de manifestações patológicas, sendo imperceptível pelo fato de o banheiro e a área de serviço possuírem revestimento cerâmico e no corredor lateral pela inexistência de revestimento argamassado.

\subsection{MÉTODO PARA CORREÇÃO DAS ANOMALIAS APRESENTADAS NA PARTE INFERIOR DO REVESTIMENTO}

Através da inspeção visual foram estabelecidas as seguintes hipóteses de diagnóstico para as anomalias. Conforme apresentado, constatou-se que em diversos pontos do revestimento das residências analisadas há a incidência das manifestações patológicas, sendo a maioria destas localizadas na parte inferior do 
revestimento de argamassa da alvenaria. Nos pontos de incidência das manifestações foi perceptível a presença de manchas características da ocorrência do agente vinculante (umidade).

A umidade presente nos pontos situados na parte inferior da alvenaria é proveniente do solo, que ascende por capilaridade oriunda tanto por presença permanente de umidade de lençóis freáticos superficiais quanto por fenômenos sazonais de aumento de umidade (QUERUZ, 2007).

No entanto, possui a possibilidade de atuação da umidade por infiltração nos revestimentos argamassados das alvenarias que limitam-se com as residências vizinhas que estão em cota superior em relação as residências de estudo, pois, de acordo com Righi et al. (2009), estas caracterizam-se como estruturas enterradas por estarem em contato permanente da alvenaria com o solo da residência de cota superior possibilitando assim, na ausência de um tratamento eficaz contra a umidade, um meio favorável para a ocorrência de infiltrações pelos capilares do material em contato com o solo.

Independente do meio de atuação, as causas da ocorrência destas umidades supracitadas estão vinculadas ao término da vida útil da impermeabilização, má execução ou até mesmo a inexistência da mesma, possibilitando assim o deslocamento da umidade livremente nos capilares dos materiais.

Para eliminar esta umidade seja ela proveniente da ascensão por capilaridade ou por infiltração as etapas propostas para a solução conforme Instituto Brasileiro de Impermeabilização - IBI (2009) são:

0 primeiro procedimento a ser realizado é fazer a delimitação da área a ser trada, fazendo a marcação de uma faixa $30 \mathrm{~cm}$ acima da manifestação patológica percorrendo toda a parede que apresentar sinais de umidade ascendente.

Nessa área que foi demarcada deve ser removido todo revestimento da parede de tal forma que a alvenaria fique exposta. Em seguida devem ser corrigidas irregularidades na alvenaria utilizando para isto argamassa.

Após a elaboração desta etapa deve ser aplicada a argamassa polimérica seguindo as instruções descritas pelo fabricante do produto.

Posteriormente executa-se novamente o revestimento que foi retirado adicionando na argamassa um aditivo hidrófugo para assim obter um melhor desempenho. A aplicação da argamassa deverá ser executada em duas ou três camadas de aproximadamente $1 \mathrm{~cm}$ de espessura, sendo feita o acabamento desejado na última camada.

Para realização da pintura ou aplicação de alguma massa acrílica ou PVA, deve ser esperado o tempo de cura da argamassa.

Solucionado o problema, deve-se evitar fazer perfurações no revestimento que foi executado o tratamento, bem como, outros procedimentos que possa danificar a impermeabilização trazendo como consequência o retorno dos problemas.

\subsection{MÉTODO PARA CORREÇÃO DAS ANOMALIAS APRESENTADAS NA PARTE SUPERIOR DO REVESTIMENTO}

Através da inspeção visual foi estabelecida a seguinte hipótese de diagnóstico para as anomalias que se situam na parte superior do revestimento argamassado da alvenaria: a umidade que propicia o meio favorável para a proliferação das manifestações patológicas é proveniente de infiltração. Esta infiltração é causada por falha na junção do telhado com o rufo, sendo uma forma de correção à realização de impermeabilização das áreas afetadas. Para realização desta impermeabilização, segundo Salgado (2014), deverá ser utilizando um impermeabilizante flexível, pois esta é uma área que possui muita variação térmica sendo inviável o uso de uma impermeabilização rígida.

Depois de realizado os procedimentos de aplicação da impermeabilização flexível, sendo esta feita de acordo com o especificado pelo fabricante do produto utilizado, deverá ser realizado o tratamento das áreas afetadas pelas manifestações patológicas.

Como as manifestações identificadas em ambos os pontos foi à proliferação de mofo ou bolor, Uemoto (1988) apresenta que para fazer esse tipo de tratamento é preciso fazer os seguintes procedimentos:

- Fazer a remoção da camada superficial do revestimento na área que esta afetada com a proliferação da manifestação patológica. 
- Lavar o local e trata-lo com produtos desinfetantes, fazendo assim a extinção como também evitando a proliferação desses fungos.

- $\quad$ Posteriormente deverá ser aplicada uma nova camada de argamassa.

- $\quad$ E para melhores resultados deverá ser utilizado uma tinta antimofo.

- $\quad$ Para evitar novos problemas deve ser feita manutenções preventivas, a fim de evitar novos problemas.

\section{CONCLUSÃO}

Conclui-se que, as residências selecionadas possuem diversos tipos de manifestações patológicas onde apresentam-se em um estado de degradação avançada, estas foram devidamente identificadas e caracterizadas. A presença da umidade que propicia o surgimento destas manifestações patológicas está vinculada a inexistência ou até mesmo ineficiência dos sistemas de impermeabilização. Isso se dá por falhas de projetos, uso de mão-de-obra desqualificada na execução ou até mesmo a utilização de impermeabilizantes inadequados.

Diante das manifestações patológicas apresentadas foram estabelecidas possíveis soluções para recuperação do revestimento argamassado afetado, bem como maneiras de barrar a presença do agente vinculante (umidade).

Pelo estado em que se encontram as manifestações patológicas, percebe-se que não há manutenções preventivas e corretivas com frequência ou mesmo o uso de procedimentos corretivos eficientes executados por profissionais qualificados. Sendo feito de forma adequada, garantirá a funcionalidade do revestimento de argamassa desempenhando o seu papel na proteção dos elementos de vedação contra agentes deteriorantes, isolamento termoacústico, além da regularização da superfície para posterior acabamento desejado. Além de tornar os ambientes das residências mais aconchegantes, livres de umidades indesejadas e com um aspecto visual harmonioso.

\section{REFERÊNCIAS}

[1] ALUCCI, M. P., FLAUZINO, W. D., MILANO, S. Bolor em edifícios: causas e recomendações. Tecnologia de Edificações, São Paulo. Pini, IPT - Instituto de Pesquisas Tecnológicas do Estado de São Paulo, Coletânea de trabalhos da Div. de Edificações do IPT. 1988. p.565-70.

[2] BAUER, R.J.F. Patologia em revestimentos de argamassa inorgânica. In: SIMPÓSIO BRASILEIRO DE TECNOLOGIA DAS ARGAMASSAS, II, 1997, Salvador. Anais... Salvador: CETA / ANTAC, 1997.

[3] CINCOTTO, M. A., SILVA, M. A. C., CARASEK, H. Argamassas de revestimento; Características, propriedades e métodos de ensaio (Publicação IPT 2378). 1.ed. São Paulo: Instituto de Pesquisas Tecnológicas, 1995. 118p.

[4] Climate data. Org. Clima Nossa Senhora do Socorro. https://pt.climate-data.org/america-dosul/brasil/sergipe/nossa-senhora-do-socorro-4456. Acesso em 10/11/2018.

[5] Dicionário Aurélio. Disponível em https://dicionariodoaurelio.com/umidade. Acessado em 09 de junho de 2018.

[6] GERHARDT, Tatiana Engel; SILVEIRA, Denise Tolfo (organizadoras). Métodos de Pesquisa. 1a Ed. Porto Alegre: Editora da UFRGS, 2009.

[7] IBI - Instituto Brasileiro de Impermeabilização. Disponível em: <http://www.ibibrasil.com.br>. Acessado em setembro/2018.

[8] KLEIN, D. L. Apostila do Curso de Patologia das Construções. Porto Alegre, 1999 - $10^{\circ}$ Congresso Brasileiro de Engenharia de Avaliações e Perícias.

[9] LICHTENSTEIN, N. B. Patologia das Construções: procedimento para formulação do diagnóstico de falhas e definição de conduta adequada à recuperação de edificações. São Paulo: Escola Politécnica da USP, 1985. Dissertação (M estrado em Engenharia Civil) - Universidade de São Paulo, 1985.

[10] Mapas Blog. Mapas de Sergipe. Disponível em https://mapasblog.blogspot.com/2011/11/mapas-desergipe.html. Acesso em 10/11/2018.

[11] MILITO, J. A. de. Técnicas de construção civil e construção de edifícios. Anotações de aula. Campinas. 
[12] QUERUZ.F. contribuição para identificação dos principais agentes e mecanismos de degradação em edificações da Vila Belga. Santa Maria:UFSM, 2007. 150 p. Dissertação (Mestrado em Engenharia Civil) - Universidade Federal de Santa Maria, 2007.

[13] RIGHI, G. V. Estudo dos sistemas de impermeabilização: patologias, prevenções e correções - analise de caso. Dissertação (Mestrado em Engenharia Civil), Universidade Federal de Santa Maria. Rio Grande do Sul, 2009.

[14] SALGADO, J.C. P. Técnicas e práticas construtivas para edificação. 3. ed. São Paulo: Érica, 2014.

[15] SEGAT, G. T. Manifestações patológicas observadas em revestimentos de argamassa: estudo de caso em conjunto habitacional popular na cidade de Caixias do Sul (RS). Dissertação (Mestrado em Engenharia Civil), Escola de Engenharia Universidade Federal do Rio Grande do Sul, 2005.

[16] UEMOTO, K. L. Patologia: Danos causados por eflorescência. Tecnologia de Edificações, São Paulo. Pini, IPT Instituto de Pesquisas Tecnológicas do Estado de São Paulo, Coletânea de trabalhos da Div. de Edificações do IPT. 1988. 


\section{Capítulo 9}

Embargo e interdição na indústria da construção civil em Aracaju/SE: Análise da percepção de alunos e profissionais da área

\section{Maria Daylanne Oliveira Santos}

Sandro Iury Valverde Lima da Cruz.

Resumo: 0 ramo da construção civil apresenta-se como uma das principais atividades para a economia do país, sendo ela responsável por aproximadamente 4,5\% do PIB brasileiro. Porém a atividade também é responsável por um dos maiores índices de acidentes e doenças do trabalho, devido às fortes pressões exercidas pelas empresas para que as obras sejam concluídas em curtos espaços de tempo, o despreparo da mão de obra que normalmente é proveniente de classes com baixo nível cultural, a grande rotatividade da mão de obra e principalmente pela cultura de descaso das construtoras pela saúde e segurança dos trabalhadores do ramo. Diante desse cenário o Ministério do Trabalho e Emprego vem intensificando, cada vez mais, fiscalizações às obras de construção civil, com o intuito de identificar situações de Risco Grave e Iminente. Quando essas situações são identificadas a obra que pode sofrer interdições ou embargos, eventos que além de apresentar altos custos para as empresas, prejudicam todo o cronograma de execução das obras. Por isso, é de suma importância que os profissionais do ramo da construção civil estejam preparados para prevenir ou enfrentar situações como essas nas obras sob sua responsabilidade. 0 presente trabalho busca analisar o nível de conhecimento dos profissionais e acadêmicos do ramo da construção civil, identificar as principais causas de embargo e interdição no município de Aracaju/SE, indicar quais as medidas de controle para evitar tais situações e orientar sobre os procedimentos de suspensão de embargo e interdição uma vez que a penalidade já tenha sido aplicada. 0 trabalho apresenta-se como uma rica fonte de pesquisa para futuros trabalhos, uma vez que é visível a escassez de referências sobre o tema.

Palavras-chave: Construção civil. Segurança do Trabalho. Embargo e Interdição. 


\section{INTRODUÇÃO}

A indústria da construção civil no Brasil é um setor que está ligado diretamente com economia nacional. De acordo com dados do IBGE esse setor tem sido responsável por aproximadamente $4,5 \%$ do Produto Interno Bruto (PIB). Outro fator importante é geração de empregos, que segundo dados da Política de Desenvolvimento Produtivo, estima-se que foi empregado aproximadamente 1.671 pessoas em 2011 (Brasil, PDP - 2012).

0 aquecimento do setor tem aumentado à quantidade de trabalhadores nas obras e consequentemente os riscos de acidentes (MONTEIRO, 2011). A Segurança do Trabalho atua na prevenção dos acidentes de trabalho (AT), visto que no canteiro de obras existem inúmeras situações de risco que podem variar de acordo com a atividade, com processo de produção e medidas de controle existentes.

Nesse contexto, uma das principais causas de acidentes em canteiro de obra é a falta de um plano de gestão de segurança, pois o mesmo consegue diminuir ou eliminar os riscos no ambiente em que o trabalhador está exposto, evitando quaisquer despesas com acidentes envolvendo profissionais, como também a paralisação da obra ou de qualquer setor de serviço. 0 Ministério do Trabalho e Emprego (MTE) criou normas regulamentadoras - NR'S, por meio da portaria $\mathrm{n}^{\circ} 3.214 / 78$, com finalidade de mostrar as irregularidades e as situações de grave e iminente risco que são encontradas no canteiro de obra (CIESP, FIESP, 2008).

As Normas Regulamentadoras $\mathrm{n}^{\circ} 03$ (Embargo e Interdição) e $\mathrm{n}^{\circ} 18$ (Condições e Meio Ambiente de Trabalho na Indústria da Construção) são importantes para padronização dos canteiros de obra, obrigando o empregador a implantar medidas administrativas de segurança, preservando assim a saúde e a integridade física do trabalhador. A empresa que descumprir qualquer procedimento acaba correndo risco de multas e infringindo a NR28, podendo ocasionar em embargo, através de uma paralisação total ou parcial da obra ou ainda acarretar numa interdição por meio de uma paralisação de máquinas, setor, estabelecimentos ou equipamentos.

0 presente trabalho teve como objetivo realizar uma investigação sobre o conhecimento dos profissionais e acadêmicos da área da Engenharia Civil, referente as principais causas e consequências de embargos e interdições em obras de construção civil no município de Aracaju/SE, além de servir como fonte de referência para futuros estudos, tendo em vista a escassez de referências que tratam sobre o tema.

\section{METODOLOGIA}

0 trabalho foi desenvolvido através de pesquisas bibliográficas, artigos da internet, consulta a sites especializados, visitas a órgãos oficiais e aplicação de questionário com engenheiros e formandos em engenharia civil da Faculdade Pio Décimo, em Aracaju/SE.

0 trabalho foi realizado na Faculdade Pio Décimo, localizada na capital Aracaju/Se, na Avenida Tancredo Neves, no Bairro Jabotiana de $\mathrm{N}^{\circ} 5655$, com uma área de aproximadamente $30.634 \mathrm{~m}^{2}$, com latitude e longitude de -10924885 e -37081605, respectivamente (Figura 1).

A faculdade atualmente dispõe de dez cursos de graduação, aproximadamente quarenta cursos de especializações nas diversas áreas de conhecimento, possui um quadro de aproximadamente de 4.000 alunos, onde 807 alunos são do curso de engenharia civil e 192 desses alunos estão matriculados no décimo período. 
Figura 1: Área de estudo e local de coleta de dados.

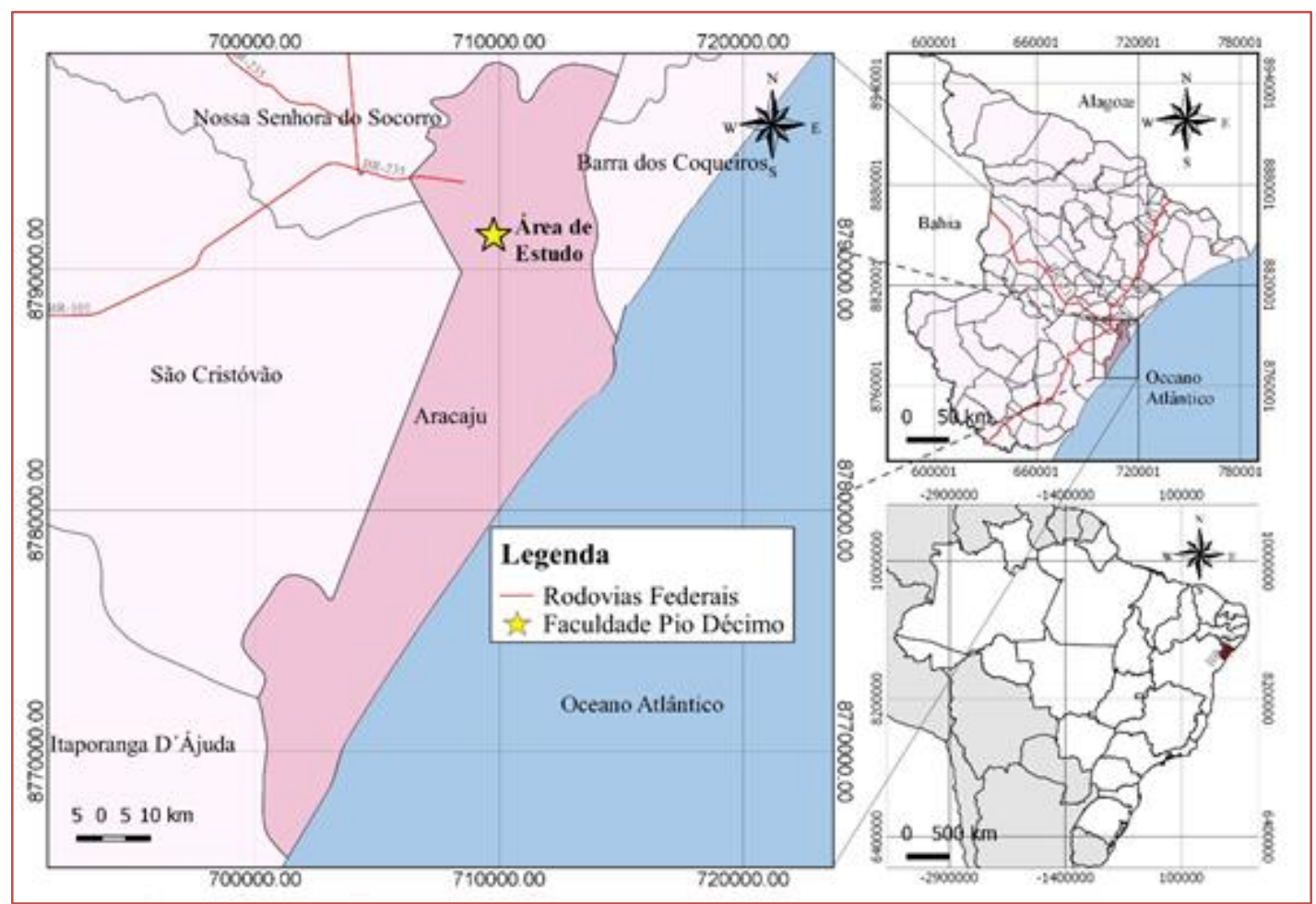

Fonte: Atlas de Recursos Hídricos, SEMARH - 2016. Projeção UTM Datum: SIRGAS 2000

A pesquisa foi de origem qualitativa e quantitativa. A coleta dos dados foi explorada através de literaturas e artigos acadêmicos, normas regulamentadoras e visita ao STRE-SE (Superintendência Regional do Trabalho e Emprego de Sergipe) no dia sete de maio de dois mil e dezoito pela manhã, permitindo um entendimento mais aprofundado do assunto, para acrescentar as informações obtidas e caracterizar melhor a coleta desses dados, esses dados foram enviados via e-mail pelo auditor fiscal do MTE.

0 questionário foi elaborado através de um método semiestruturado, o qual foi aplicado entre alunos de graduação em engenharia civil e alunos de pós-graduação em engenharia de Segurança do Trabalho, ambos na Faculdade Pio Décimo. 0 formulário é composto por quatorze questões, sendo elas de caráter objetivo e subjetivo, com o objetivo de verificar o conhecimento desses profissionais e dos formandos, no que diz respeito à embargo e interdição.

Ressalta que o curso de pós-graduação em engenharia de Segurança do Trabalho possui um número de 150 alunos matriculados, totalizando três turmas. No dia da visita para aplicação do questionário foi levado um total de 50 questionários e foi feita a distribuição desses questionários, porém 39 desses foram devolvidos em brancos e apenas 11 desses questionários foram respondidos. Segundo Fachin (2017), o pesquisado pode devolver o questionário em branco ou incompleto em face do desinteresse ou da falta de tempo. Considerou-se essa etapa como Momento 1.

Já para a turma do décimo período de graduação em engenharia civil que possui um número de 192 alunos matriculados no curso, dividindo-se em duas turmas. 0 questionário foi aplicado durante uma semana e foi impresso um total de 60 questionários, porém durante a aplicação notou-se a insatisfação dos alunos para respondê-lo por apresentar muitas questões abertas.

Dos 60 questionários entregues, 30 foram respondidos. Entretanto nas turmas do curso de engenharia civil existiam alunos matriculados no décimo período, mas com matérias pendentes em outros períodos. Considerou-se esta etapa como Momento 2. No final de toda atividade, somou-se as amostras do Momento 1 e Momento 2, totalizando 41 alunos que contribuíram nesta pesquisa, considerando um erro experimental de $15 \%$ desses alunos (BARBETA, 1999).

O objetivo do questionário era perceber alguns conceitos sobre risco grave e iminente, qual a norma que rege o embargo e interdição, diferença entre eles, quais os procedimentos relativos e de suspensão do mesmo, se obtiveram algum conceito durante a graduação ou na vida profissional, as causas mais frequentes de embargo e interdição, de que forma o embargo e interdição implica no custo de uma obra, se 
os mesmos saberiam como lidar com esse tipo de situação e sobre a autoridade do auditor fiscal para embargar ou interditar uma obra.

As respostas dos questionários aplicados foram comparadas com os conceitos obtidos da Norma Regulamentadora $\mathrm{N}^{\circ} 03$ e posteriormente os resultados foram tabulados para a elaboração de gráficos desenvolvidos no software Microsoft Excel versão 2016, que possibilitou a melhor compreensão do nível de conhecimento da amostragem proposta.

\section{RESULTADOS E DISCUSSÃO}

Dos questionários avaliados $73,17 \%$ foi aplicado com os graduandos no curso de engenharia civil e 26,83\% do questionário foi desenvolvido com alunos de pós-graduação em Engenharia de Segurança do Trabalho.

Segundo Silveira (2005), o engenheiro civil possui um papel social que sofre influência pela imagem construída pelo Sistema Educacional de sua formação que transmite tanto para o mercado quanto para sociedade, em razão disso esses papéis se afastam, em bom grau de suas funções técnicas e passa a ser definido como um status social desses profissionais.

Das quatorze questões presentes no questionário, foram selecionadas nove e no decorrer da aplicação foram observadas algumas dificuldades no desenvolver das questões. As dificuldades estavam relacionadas ao raso conhecimento obtido durante a graduação, ou não aprofundamento do conteúdo estabelecido na Norma Regulamentadora $\mathrm{n}^{\circ}$ 3, do Ministério do Trabalho e Emprego, e identificou-se ainda a falta total de conhecimento sobre o tema abordado.

Dentro das questões avaliadas estava o conceito de risco grave e iminente, que segundo a NR3 (2011,p.1) "considera-se toda condição ambiental de trabalho que possa causar acidente do trabalho ou doença profissional com lesão grave à integridade física do trabalhador".

Levando em consideração o conceito da norma citado acima, metade dos graduandos tem conhecimento sobre o conceito de risco grave e iminente e os outros $50 \%$ desconhecem do assunto. Já em relação aos percentuais dos profissionais, $63,64 \%$ sabiam desse conceito e $36,36 \%$ ficou entre os que deixaram o campo de resposta em branco e os que responderam ou preencheram de maneira incorreta (Figura 02).

0 pesquisado de número 9

Risco Iminente que pode ocorrer a qualquer momento

Risco Grave depende do dano que ele possa causar

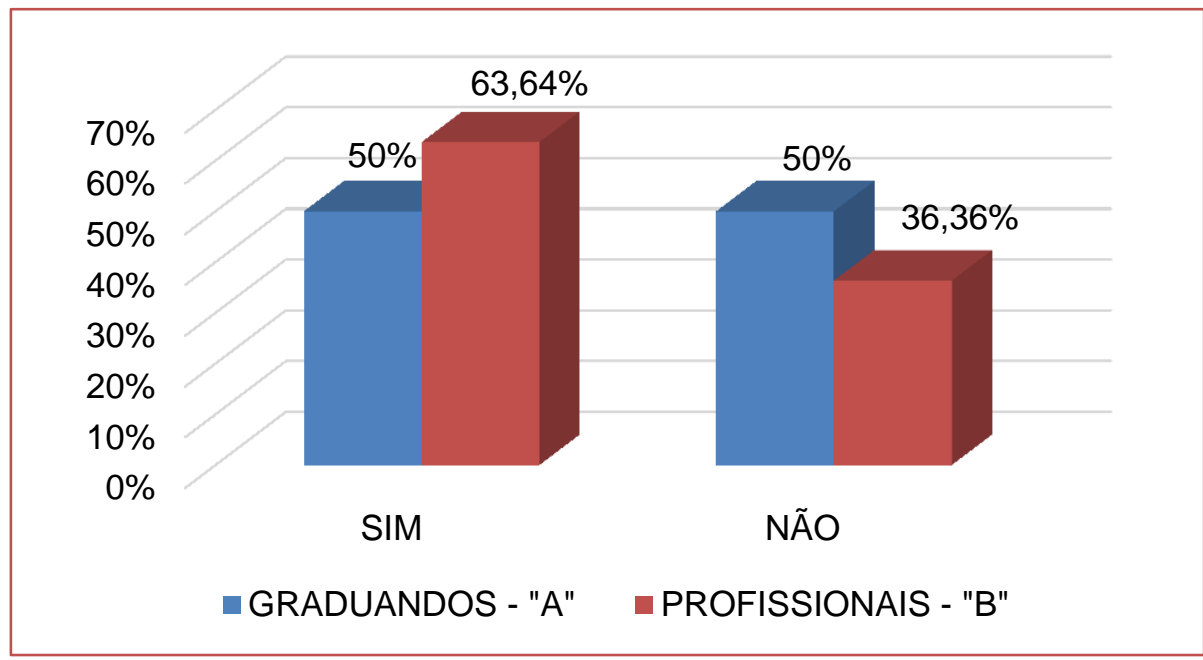

Figura 2: Quantitativo de pessoas quanto ao conhecimento sobre risco grave e iminente

Fonte: autor, 2018. 
Das questões selecionadas estava também os procedimentos de suspensão do embargo ou interdição, que de acordo com a portaria $n^{\circ} 1.719$ (2014) da Lei, esses procedimentos podem ser requeridos, desde que todas as medidas de segurança e saúde no trabalho indicadas no relatório técnico sejam cumpridas, o requerimento para embargo e interdição será incorporado no processo administrativo.

O setor de inspeção do trabalho deverá fazer uma nova inspeção no local para que seja verificada se todas as irregularidades foram sanadas e deverá elaborar um novo relatório técnico e formalizado por meio de Termos de Suspensão de Embargo e Interdição.

As respostas da questão 5 do questionário, comparada com o que é estabelecido na portaria ${ }^{\circ} 1.719$ (2014) sobre os procedimentos de embargo e interdição, 100 \% dos graduandos e 100\% dos profissionais não possuem nenhum conhecimento desses procedimentos (Figura 03).

O pesquisado de número 16

Apresentação de relatório, projeto de cálculo, laudo ou outro documento pelo empregador, conforme previsto no relatório técnico.

Figura 3: Quantitativo de pessoas quanto ao conhecimento dos procedimentos de suspensão do embargo e

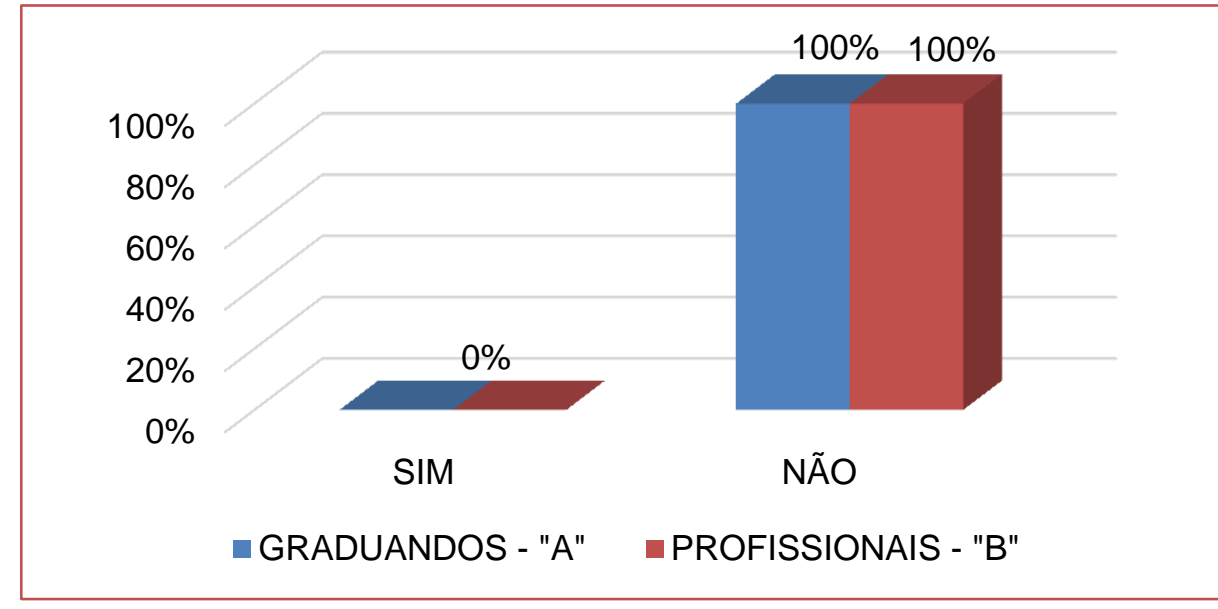

interdição

Fonte: autor, 2018.

A questão sobre o conhecimento dos indivíduos sobre a abordagem desse conteúdo na graduação e seu aprofundamento revelou que 70\% dos graduandos tiveram algum conhecimento sobre o tema, porém de forma bem superficial e 30\% não possuíam entendimento sobre o assunto. No que diz respeito a parcela dos profissionais, $36,36 \%$ teve o conteúdo abordado durante graduação e $63,64 \%$ responderam que esse assunto não foi abordado durante o curso superior (Figura 04).

0 pesquisado de número 32

Sim, bem superficial. 
Figura 04: Quantitativo de entrevistados quanto ao conhecimento durante a graduação

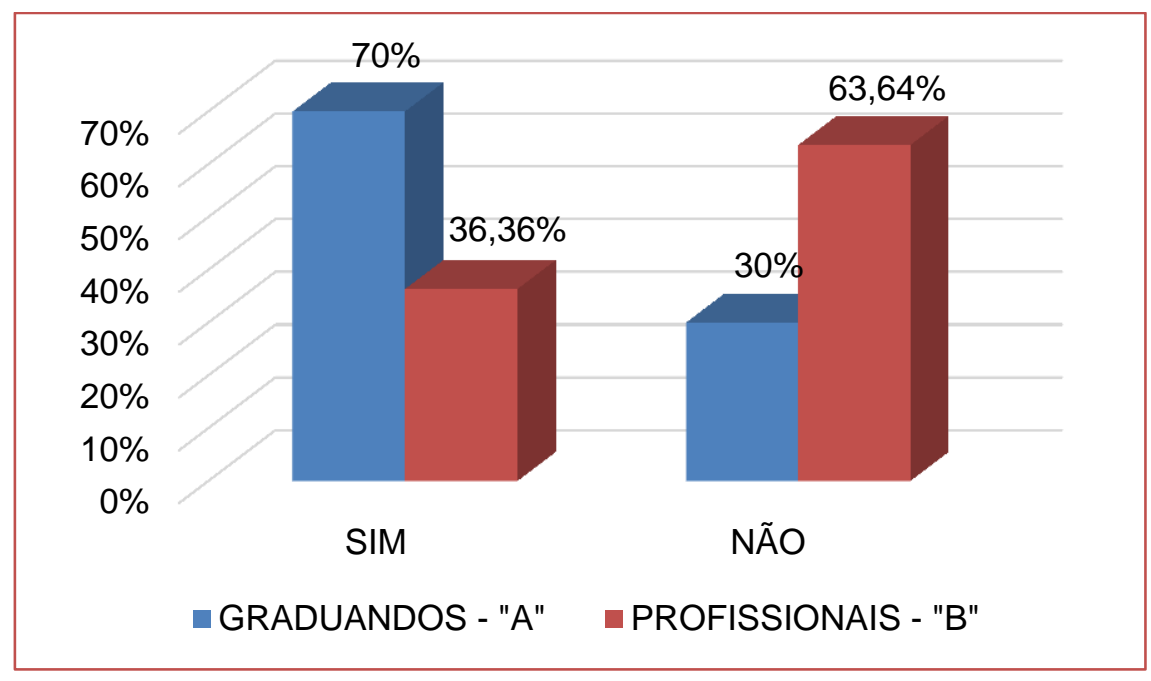

Fonte: autor, 2018.

De acordo com Neto (2018), muitas faculdades de engenharia aplicam o método tradicional de ensino, que acontecem através da transmissão de conteúdos por meio de aulas expositivas, no qual os alunos têm apenas a função de adquirir conhecimento através dos professores. Entretanto, o mundo profissional de hoje precisa de profissionais técnicos e com habilidades no exercício profissional e essas habilidades devem ser desenvolvidas durante a graduação.

A pergunta sobre como as pessoas saberiam resolver uma situação de embargo e interdição, dos graduandos, $76,67 \%$ responderam que não saberiam resolver um caso como esse e $23,33 \%$ saberiam resolver esse tipo de situação. Os profissionais, apesar de apresentar um percentual menor de questionários respondidos, observou-se que $72,73 \%$ não saberiam lidar com esse problema, já profissionais da área, e 27,27\% conseguiriam resolver esse tipo de situação (Figura 05).

0 pesquisado de número 1

Não, mas iria buscar informações relacionadas para que seja possível tomar as medidas de contorno da situação.

Figura 05: Quantitativo de pessoas quanto a resolver uma situação de embargo ou interdição

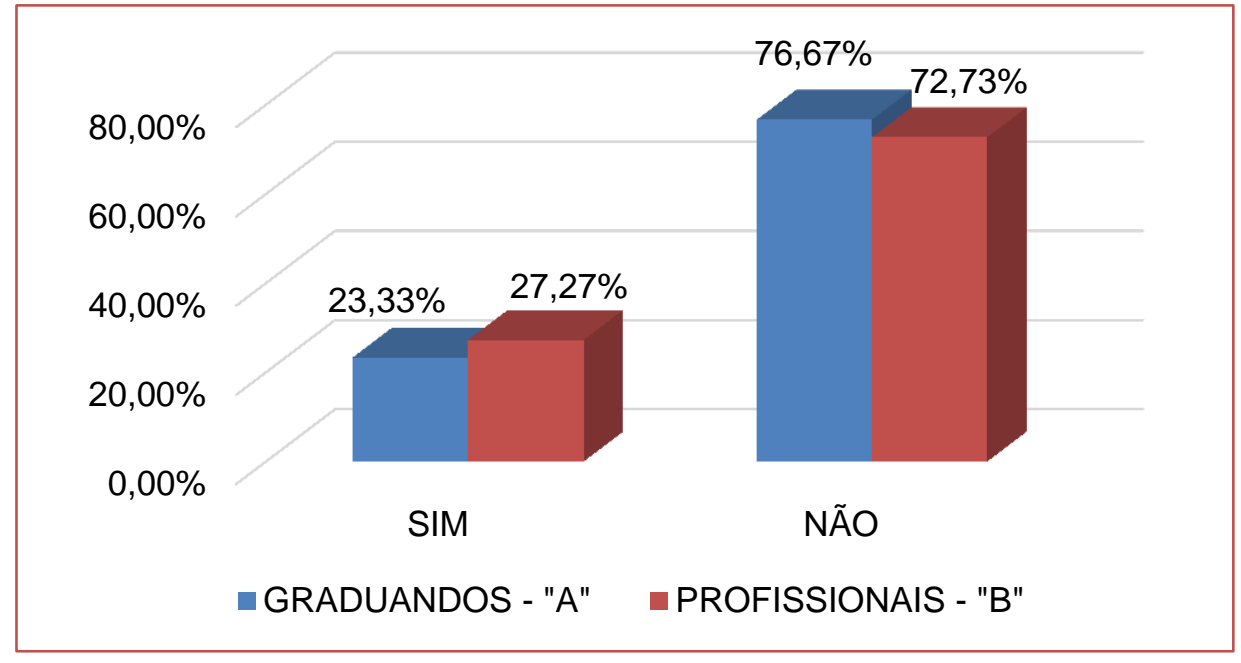

Fonte: autor, 2018 
Na prática, o profissional de engenharia parte da concepção de problemas gerados no seio da sociedade e das inovações tecnológicas e que para resolver esses problemas é necessário capacitação, habilidades, competências e valores, porém, esses requisitos ainda não estão presentes na formação dos profissionais da área (SILVEIRA, 2005).

Entre as questões avaliadas do questionário, estava a pergunta sobre de que forma o embargo ou interdição implica no custo de uma obra (Figura 06). Da análise, 63,63\% não tinham conhecimento de como o embargo e interdição implica no custo de uma obra e 36,36\% sabiam dessa informação. Apesar de ter uma menor quantidade de questionários aplicados, os profissionais obtiveram um maior percentual das pessoas que não tinham conhecimento desse fato em relação aos graduandos.

Já os alunos do décimo período de engenharia civil, 46,67\% tinham conhecimento do embargo e interdição implica no custo de uma obra e 53,33\% não tinham esse conhecimento (Figura 06). Apesar de alguns não atuarem no mercado de trabalho, os graduandos tiveram um percentual mais significativo que os profissionais, o que preocupa, com isso mostra a importância do aprofundamento de conhecimento sobre o tema.

0 pesquisado de número 2

Dependerá do porte da obra e em que ponto foi embargado.

Figura 06: Quantitativo de pessoas referente ao conhecimento sobre o quanto embargo ou interdição implica no custo de uma obra.

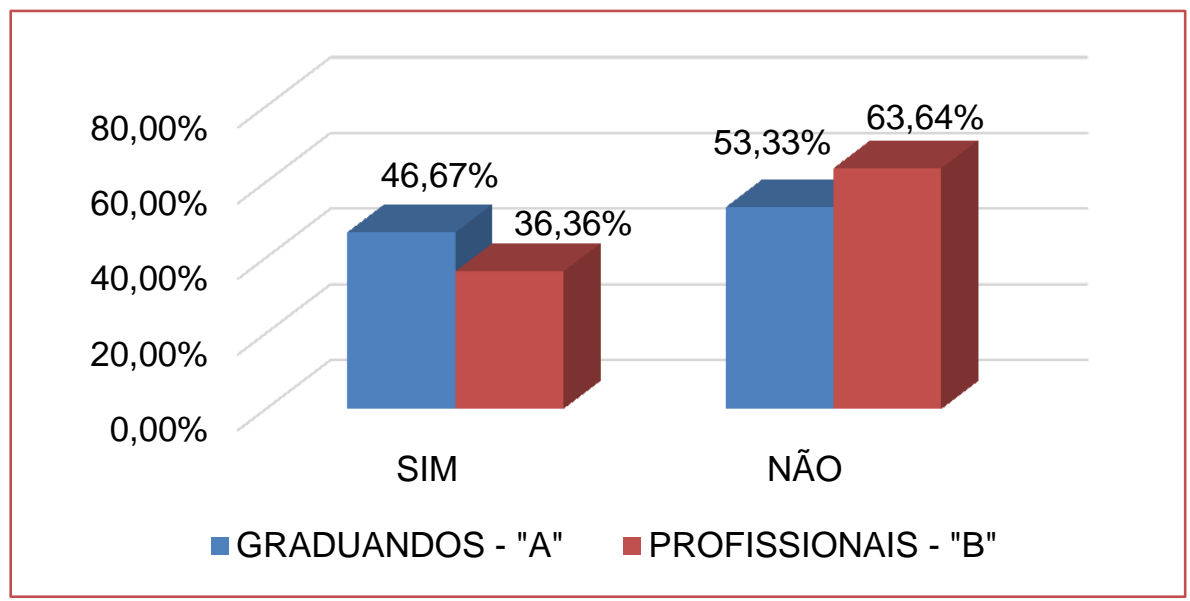

Fonte: autor, 2018.

Os danos causados pela falta de segurança nos canteiros de obras não se restringem só aos custos relacionados com os acidentes de trabalho, o que acarreta na insatisfação entre os trabalhadores, mas também aos danos provocados pelas atuações, embargos e interdições (BRASIL, 2012).

A pergunta a respeito de se as pessoas presenciaram alguma situação de embargo e interdição apontou que $100 \%$ dos graduandos e 100\% dos profissionais nunca presenciaram uma situação de embargo ou interdição, mesmo aqueles que já trabalham na área ou fazem estágio no ramo da construção civil, todos os pesquisados deixaram o campo de resposta em branco (Figura 07). 
Figura 07: Quantitativo de pessoas que não presenciaram uma situação de embargo e interdição

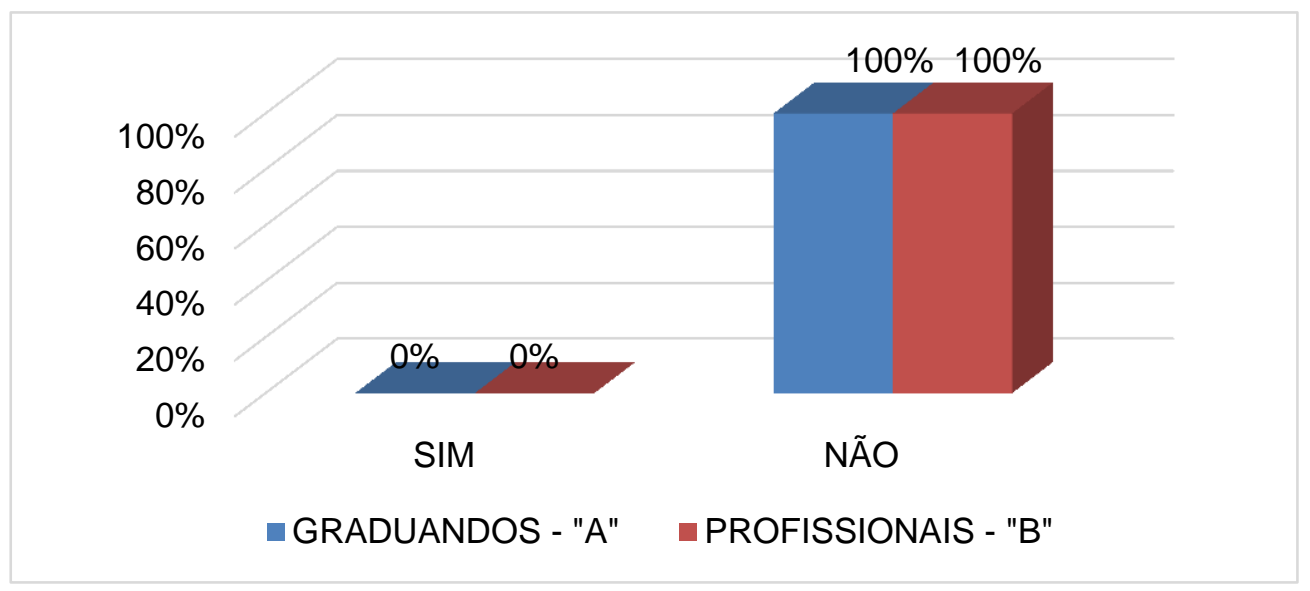

Fonte: autor, 2018.

Segundo Lucena (2001), a aprendizagem é um conceito que não se pode dissociar do ato de viver, que também acontece no exercício profissional e que através da experiência e da prática, é estabelecido o processo de formação do conhecimento.

Das perguntas analisadas, estava a questão sobre as causas mais frequentes para a ocorrência de embargo ou interdição. Segundo o MTE (2018), as causas mais frequentes para ocorrência de embargo ou interdição são: trabalho em altura pelo não cumprimento da NR-35, andaimes irregulares, o não uso de proteção de periferia, sistemas de transmissão de força desprotegidos como polias e engrenagens, falta de aterramento de máquinas e equipamentos elétricos, falta de gestão em saúde e segurança por parte de gestores, instalações elétricas sem projeto e instaladas de forma irregular, desprotegida e fora dos padrões da NR-10 e NR-18.

De posse desses dados do MTE, quanto as causas mais frequentes de embargo e interdição, que representa a questão 12 do questionário, $40 \%$ dos graduandos tem conhecimento dessas causas e $60 \%$ não possui essa informação, quanto aos profissionais $36,36 \%$ e $63,64 \%$ responderam que sabiam dessas causas e que desconheciam dessas causas, respectivamente (Figura 08).

0 pesquisado de número 12

As condições de risco grave e iminente causados por um equipamento ou obra.

Figura 08: Quantitativo de pessoas referente ao conhecimento das causas mais frequentes para ocorrência de embargo ou interdição

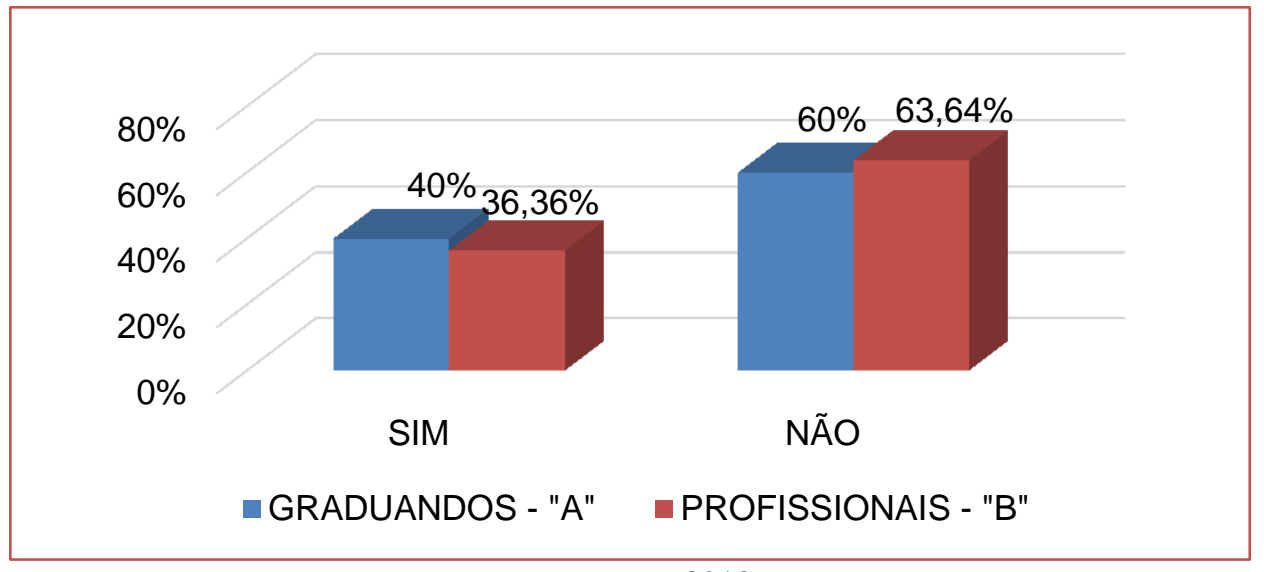

Fonte: autor, 2018. 
Segundo a NR3 (2011, p.1):

Responderá por desobediência, além das medidas penais cabíveis, quem, após determinada a interdição ou o embargo, ordenar ou permitir o funcionamento do estabelecimento ou de um dos seus setores, a utilização de máquinas ou equipamento, ou o prosseguimento da obra, se em consequência resultarem danos a terceiros.

Comparando-se com o conceito da NR3, citado acima, a maioria das pessoas que responderam o questionário, tem o conhecimento que no descumprimento do embargo ou interdição o empregador pode responder criminalmente por isso. Dos graduandos, $66,67 \%$ tem conhecimento de que o empregador responde criminalmente por não cumprir o que foi solicitado e 33,33\% não sabem que o empregador responde criminalmente por descumprir uma situação como essa, logo os profissionais, 90,91\% responderam ter esse conhecimento do assunto e 9,09\% não possuía esse entendimento (Figura 09).

Figura 09: Quantitativo de pessoas quanto ao conhecimento do empregador responder criminalmente pelo descumprimento do embargo ou interdição

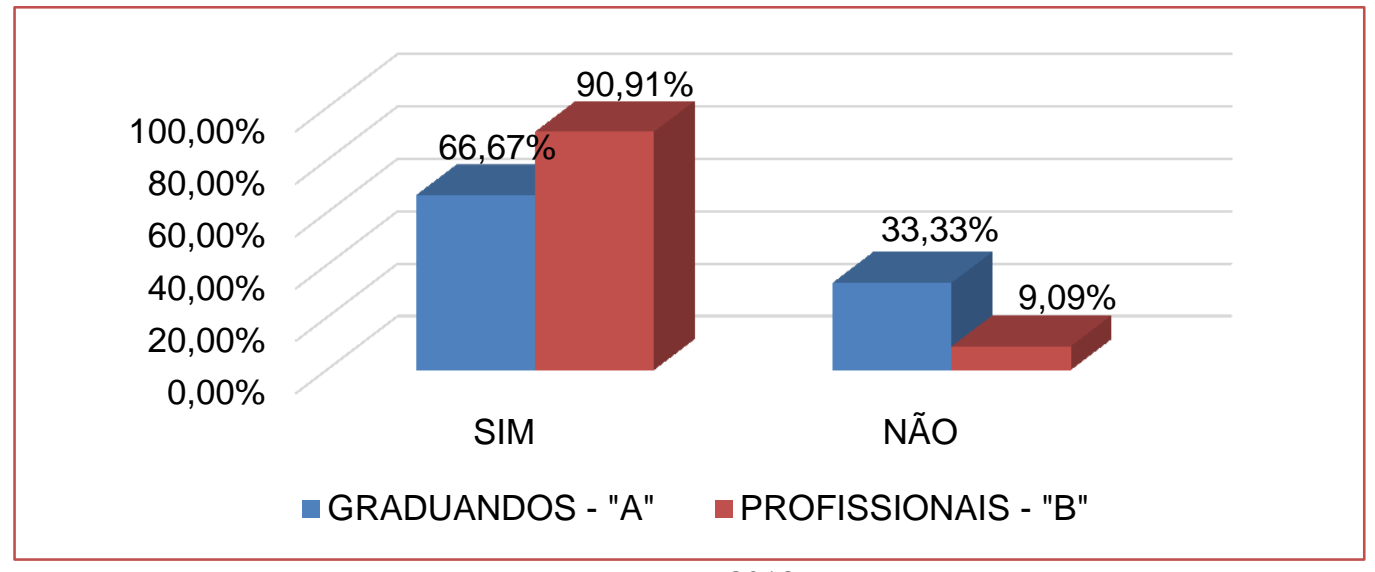

Fonte: autor, 2018.

Dentro das perguntadas analisadas estava também a questão do auditor fiscal necessitar de especialização para embargar ou interditar uma obra, que de acordo com a Lei 10593/02 do Art. 11, para ocupar o cargo de auditor fiscal, eles têm por atribuições assegurar no cumprimento de disposições legais e regulamentares, até mesmo relacionadas à segurança e à medicina do trabalho e no âmbito das relações de trabalho e emprego (BRASIL, 2002).

Segundo o que é estabelecido na Lei 10593/02 do Art. 11, comparou-se com as repostas da questão 14 do questionário e poucas pessoas sabiam da necessidade de especialização do auditor fiscal para embargar ou interditar uma obra. A percentagem dos graduandos ficou distribuída entre 20\% dos que tinham conhecimento dessa especialização, 66,67\% não sabiam que o auditor fiscal precisa de uma especialização para embargar ou interditar uma obra e 13,33\% desconheciam dessa especialização do auditor fiscal, já os profissionais, 36,36\% tinha conhecimento que para embargar ou interditar o auditor fiscal necessita de especialização, 36,36\% não possuíam esse conhecimento e 27,28\% desconheciam do assunto (Figura 10).

O pesquisado de número 31

Precisa saber o principal motivo que está gerando o embargo ou interdição. 
Figura 10: Quantitativo de pessoas referente ao conhecimento do auditor fiscal necessitar de especialização para embargar ou interditar uma obra

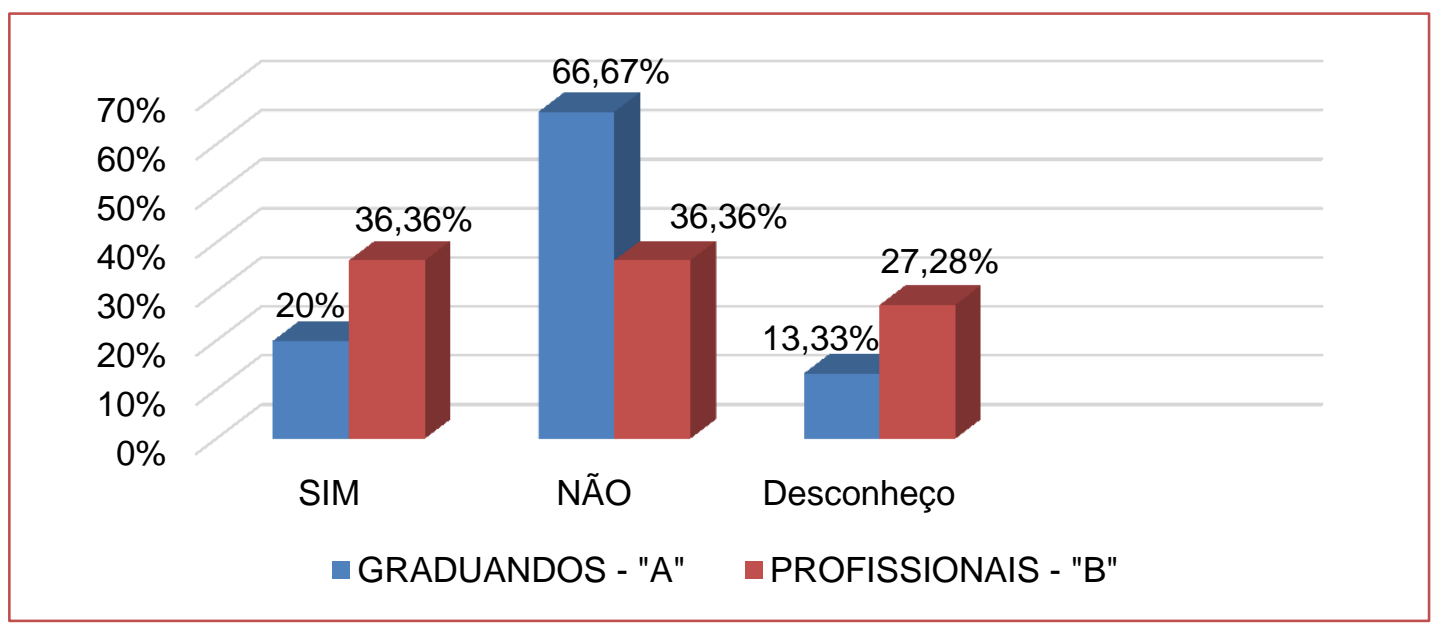

Fonte: autor, 2018.

A respeito dos procedimentos de suspensão do embargo e interdição da questão 05 do questionário, nenhum dos entrevistados tinham conhecimento sobre o assunto (Figura 11). Sobre a questão 11, que trata dos entrevistados que presenciaram uma situação de embargo ou interdição, nenhum deles presenciaram esse tipo de situação.

Em síntese, do total de entrevistados, 53,66\% tinham conhecimento do conceito de risco grave e iminente (Questão 01), 60,98\% tiveram conteúdo abordado durante a sua graduação (Questão 06), 24,39\% saberiam resolver uma situação de embargo e interdição (Questão 07) e sabem da necessidade de especialização do auditor fiscal (Questão 14), 43,90\% sabem que o embargo e interdição implicam no custo de uma obra, 39,02\% tem conhecimento das causas mais frequentes desse conteúdo e 73,17\% conhecem que no descumprimento desse tipo de situação, o empregador responderá por isso criminalmente (Questão 13) (Figura 11).

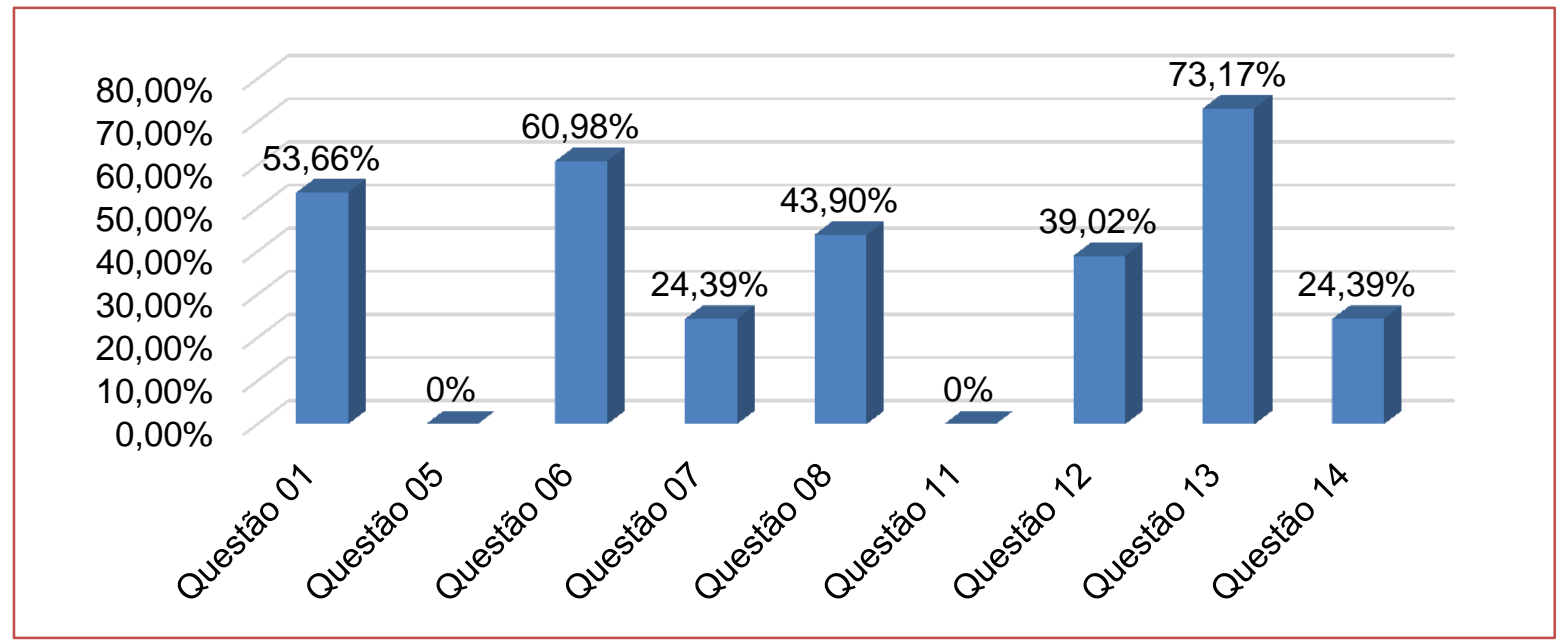

Figura 11: Quantitativo de pessoas referente ao conhecimento das questões abordadas

Fonte: autor, 2018.

\section{CONSIDERAÇÕES FINAIS}

Ao final do trabalho foi possível concluir que a maioria dos profissionais que atuam como responsáveis técnicos de obras de construção civil, e que atualmente estão cursando a especialização de engenharia de 
segurança e medicina do trabalho, ainda apresentam uma grande fragilidade no conhecimento relacionado ao tema, mesmo sendo punições que causam o atraso das obras e que implicam em altos custos.

A falta de conhecimento sobre o tema é evidente quando se trata dos alunos de graduação que estão cursando o último período do curso de engenharia civil. Isso demonstra que há uma fragilidade nas matrizes curriculares dos cursos de graduação referente a um tema que é frequente e de suma importância na vida profissional dos futuros profissionais. Apesar desse conteúdo ser apresentado nas ementas de algumas disciplinas, a escassez de referências e palestras orientadoras sobre o tema contribui para a falta de informações dos profissionais.

Conclui-se ainda que o próprio Ministério do Trabalho e Emprego não possui um sistema de registro eficiente dos casos de ocorrência de embargo e interdição em obras de construção civil no município de Aracaju/SE. Esse registro é uma fonte de informações de suma importância para que se possa identificar os erros mais frequentes e realizar um trabalho de conscientização dos profissionais, uma vez que a função do Ministério do Trabalho e Emprego não é só de punir, mas sim, de orientar.

\section{REFERÊNCIAS}

[1] ASSOCIAÇÃO BRASILEIRA DE NORMAS TÉCNICAS. NR3: Embargo ou Interdição. Sem ed. 2011.1 p. Disponível em: <http://trabalho.gov.br/images/Documentos/SST/NR/NR3.pdf>. Acesso em: 24 abr. 2018.

[2] ASSOCIAÇÃO BRASILEIRA DE NORMAS TÉCNICAS. NR9: PROGRAMA DE PREVENÇÃO DE RISCOS AMBIENTAIS. Sem ed. 2016. 13 p. Disponível em: <http://trabalho.gov.br/images/Documentos/SST/NR/NR09/NR09-2016.pdf>. Acesso em: 26 abr. 2018.

[3] ASSOCIAÇÃO BRASILEIRA DE NORMAS TÉCNICAS. NR17: ERGONOMIA. Sem ed. 2007. 14 p. Disponível em: <http://trabalho.gov.br/images/Documentos/SST/NR/NR17.pdf>. Acesso em: 26 abr. 2018.

[4] ASSOCIAÇÃO BRASILEIRA DE NORMAS TÉCNICAS. NR18: CONDIÇÕES E MEIO AMBIENTE DE TRABALHO NA INDÚSTRIA DA CONSTRUÇÃO. Sem ed. 2015. 66 p. Disponível em:

<http://trabalho.gov.br/images/Documentos/SST/NR/NR18/NR18atualizada2015.pdf>. Acesso em: 28 abr. 2018.

[5] ASSOCIAÇÃO BRASILEIRA DE NORMAS TÉCNICAS. NR28: FISCALIZAÇÃO E PENALIDADES. Sem ed. 2017. 53 p. Disponível em: <http://trabalho.gov.br/images/Documentos/SST/NR/NR-28.pdf>. Acesso em: 30 abr. 2018.

[6] BARBETTA, P. A. Estatística aplicada às Ciências Sociais. 3.ed. Florianópolis: Ed. da UFSC, 1999.

[7] BRASIL. Decreto no 6.042, de 12 de fevereiro de 2007. Disponível em:

<http://www.planalto.gov.br/ccivil_03/_ato20072010/2007/decreto/d6042.htm>. Acesso em: 12 abr. 2018.

[8] BRASIL. Lei no 10.593, de 06 de dezembro de 2002. Disponível em:

<https://www.jusbrasil.com.br/topicos/11026189/artigo-11-da-lei-n-10593-de-06-de-dezembro-de-2002>. Acesso em: 03 maio 2018.

[9] BRASIL. Lei no 5.452, de 01 de maio de 1943. Disponível em:

<https://www.jusbrasil.com.br/topicos/10748282/artigo-161-do-decreto-lei-n-5452-de-01-de-maio-de-1943>. Acesso em: 15 abr. 2018

[10] BRASIL. Lei no 8.212, de 24 de Julho de 1991. Disponível em:

<http://www.planalto.gov.br/ccivil_03/leis/18212cons.htm> Acesso em: 30 abril. 2018.

[11] Brasil. Ministério do Trabalho e Emprego. Superintendência Regional do Trabalho e Emprego do Rio Grande do Sul. Embargo e interdição: instrumentos de preservação da vida e da saúde dos trabalhadores; A experiência da Seção de Segurança e Saúde do Trabalhador - SEGUR. - Porto Alegre: Superintendência Regional do Trabalho e Emprego do Rio Grande do Sul. Seção de Segurança e Saúde do Trabalhador/SEGUR, 2010.

[12] BRASIL. Ministério do Trabalho. Lei no. Lei 6.367/76 de 19 de outubro de 1976. Lei do acidente do trabalho, aprovada pela Portaria no 3.212/78 do Ministério do Trabalho. Segurança e Medicina do Trabalho, São Paulo, v. 16, Atlas. 1998.

[13] BRASIL. Ministério do Trabalho. Secretaria de Segurança e Saúde no Trabalho. Campanha nacional de prevenção de acidentes do trabalho (CANPAT). Aracaju, 2018.

[14] BRASIL. Portaria no 1.719, de 05 de novembro de 2014. . Disponível em: <http://www.normaslegais.com.br/legislacao/Portaria-mte-1719-2014.htm>. Acesso em: 15 maio 2018.

[15] BRASIL. Resultados da Fiscalização em Segurança e Saúde no Trabalho - Brasil - 1996 a 2012. 2012. Disponível em: <http://portal.mte.gov.br/seg_sau/resultados-da-fiscalizacao-emseguranca-e-saude-no-trabalhobrasil-1996-a-2009.htm>. Acesso em: 23 maio 2018. 
[16] CIESP; FIESP; Legislação de Segurança e Medicina no Trabalho. Disponível em: <www.fiesp.com.br/download/legislacao/medicina_trabalho.pdf>. Acessado em: 02 maio. 2018.

[17] Fachin, Odília. Fundamentos de metodologia / Odília Fachin. - 6. ed. - São Paulo: Saraiva, 2017.

[18] LUCENA, E.A. A aprendizagem profissional de gerentes-proprietários do setor de varejo de vestuário de Florianópolis. Tese (doutorado em engenharia de produção) - Centro Tecnológico, Universidade Federal de Santa Catarina, Florianópolis, 2001.

[19] MONTEIRO, Daniel. Construção Civil é área propicia a acidentes. (2011) Disponível Em :<http://jornalpp.com.br/cidades/item/4428-constru\%C3\%A7\%C3\%A3o-civil-\%C3\%A9-\%C3\%A1reaprop\%C3\%ADcia-a-acidentes >Acessado em: 02 maio. 2018.

[20] NETO, Octavio Mattasoglio. Análise de Experiências de Aprendizado em Engenharia Civil, 2018. Disponível: em < http://www.entretantoeducacao.com.br/analise-de-experiencias-de-aprendizado-com-base-emproblematizacao-e-projetos-em-cursos-de-engenharia-civil/>. Acesso em: 10 junho 2018.

[21] SILVEIRA, M. A. da. A Formação do Engenheiro Inovador: Uma Visão Internacional/ Marcos Azevedo da Silveira. 1 a. Ed. Rio de Janeiro: PUC-RioABENGE, 2005. V. 1. 197p. Disponível em: http://www.maxwell.vrac.pucrio.br/7482/7482.PDF - Acessado em: 06 junho de 2018. 


\section{Capítulo 10}

\section{Estudo das propriedades do concreto utilizando como parte do cimento a cinza de casca de arroz}

\section{Vinícius Sousa dos Santos}

Romário de Jesus Santo

\section{Bárbara Maria Gomes Santana}

Resumo: Tendo em vista o alto consumo de cimento que vem sendo produzido e os problemas ambientais ocasionados pela sua produção, busca-se a utilização de cinzas advindas de processo de combustão para geração de energia em forma de adição mineral, onde está sendo bastante utilizado no concerto de cimento Portland para efeitos de estudos. Dentre os principais fatores para sua utilização tem-se: preocupação ambiental com a emissão de gases gerados durante a fabricação do cimento e a economia de energia na sua produção, e pelas cinzas ao serem depositadas de maneira indevida na natureza e com a sua poluição. Dentre essas cinzas que são geradas em processos agroindustriais, a cinza de casca de arroz (CCA) possui um destaque devido a sua elevada atividade pozolânica que traz bons resultados as propriedades do concreto, como é apresentado em pesquisas na área. 0 presente trabalho tem o objetivo de analisar a influência da CCA na resistência à compressão axial do concreto, a partir da análise de corpos de provas com a substituição de cimento Portland por CCA em teores de 5, 10 e 20\%. 0 experimento iniciou-se pela produção da CCA a qual não se obtive êxito, devido à falta de equipamentos adequados para a produção, então a cinza teve que ser comprada já pronta, em seguida foi separado os materiais para a produção do concreto, foram moldados os corpos de provas, utilizados para analisar a influência na propriedade mecânica. Foi realizado o ensaio de rompimento de corpo de prova, chegando a uma conclusão que o concreto com adições minerais não obteve uma resistência alta nos primeiros dias de rompimento, devido a hidratação do concreto ser mais lenta e alguns fatores que influenciaram na produção do concreto e por não ter utilizado aditivos.

Palavras-chave: Adições minerais. Cinza de casca de arroz. Sustentabilidade. 


\section{INTRODUÇÃO}

A produção do cimento aumenta significante com o tempo. No Brasil, em 2018, foi produzido cerca de 52,7 milhões de toneladas de cimento, de acordo com a pesquisa do Sindicato Nacional da Indústria de Cimento - SNIC. Já o concreto estima-se que o seu consumo mundial seja de ordem de 5,5 bilhões de toneladas por ano, sendo a indústria do concreto maior consumidora de reservas naturais (SOKOLOVIEZ, 2009).

A cada uma tonelada de cimento que se é produzido, são lançadas ao ar aproximadamente uma tonelada de monóxido de carbono (CO2), um dos causadores do efeito estufa. Desta forma, é de grande importância a busca por matérias-primas que ajudem e contribuam para a redução dos impactos, sem comprometer o desempenho do concreto. Segundo Sokoloviez (2009) são utilizados para substituir parte do cimento, adições minerais como subprodutos industriais ou resíduos agroindústrias. As adições minerais sao utilizadas nos diversos tipos de concreto, com vantagens na área econômica, técnica e principalmente ambiental.

Uma das adições minerais utilizadas para substituição de parte do cimento na mistura do concreto é a cinza de casca de arroz - CCA. Esta adição mineral é um resíduo decorrente do processo da queima da casca de arroz, onde é utilizada para várias situações, umas delas a geração de energia. A Casca de Arroz CA é um resíduo agroindustrial que possui na sua composição 50\% de celulose, $30 \%$ de lignina e $20 \%$ de resíduos inorgânicos, sendo que os resíduos inorgânicos possuem em média de $5 \%$ a $8 \%$ em massa de dióxido de silício SiO2 (GURGEL,2012).

0 trabalho tem como objetivo analisar através de dosagem experimental a influência da substituição parcial de cimento pela cinza de casca de arroz em teores de $5 \%, 10 \%$ e $15 \%$ com os fatores a/c 0,568, 0,586 e 0,60, nas propriedades mecânicas, com idades de 3, 7 e 14 dias de tempo de cura, realizando ensaios pertinentes à resistência do concreto e mensurando os dados obtidos para verificar a viabilidade do uso de CCA (cinza de casca de arroz) para a obtenção de um material alternativo a base de concreto e apresentar uma possível solução para o atual problema ambiental.

Sendo assim, foram realizados ensaios de resistência à compressão axial para os traços supracitados, com a finalidade de observar os desempenhos das variáveis relacionadas com a resistência mecânica do concreto.

\section{METODOLOGIA}

Esta pesquisa pode ser caracterizada como um estudo do tipo comparativo-qualitativo, onde serão comparados os dois tipos de concreto, e analisado a qualidade de ambos. Quanto a sua natureza, pode ser classificada como aplicada, pois objetiva gerar conhecimento para aplicação prática, direcionados à análise da viabilidade sustentável e o aumento de resistência da estrutura em questão.

0 desenvolvimento do trabalho de conclusão de curso foi obtido primeiramente por uma etapa de pesquisa e revisão bibliográfica com temas conexos à problemática de verificação no que se aludem as características, metodologias e materiais empregados as propriedades do concreto. Tendo como principal finalidade a substituição de porcentagens do cimento Portland por cinza de casca de arroz, na produção do concreto, onde será avaliado e comparado a sua resistência a compressão axial.

Para começar o programa experimental precisou coletar as cascas de arroz (CA) para a produção das cinzas, essas cascas foram obtidas em uma fábrica de arroz localizada no município de Propriá no estado de Sergipe há $98 \mathrm{~km}$ de distância da capital Aracaju, na fábrica de arroz de onde foram coletados as CA (Figura 1). 
Figura 1: Fábrica de Arroz na cidade de Propriá - SE

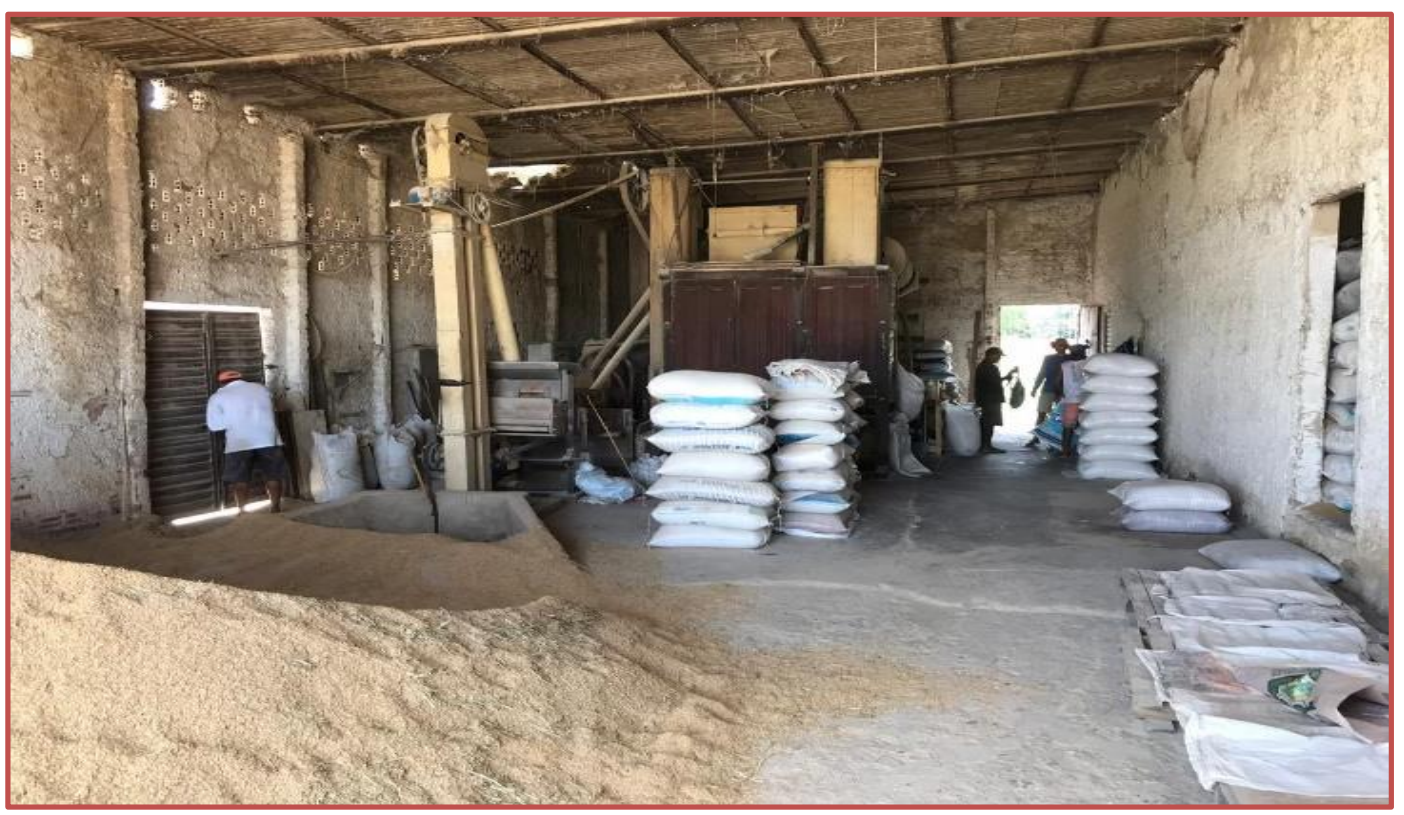

Fonte: Jeferson Gusmão, 2019.

Em seguida após conseguir as CA, foram iniciados os procedimentos de produção da CCA, onde deveria ser realizada em uma mufla à $800 \mathrm{C}$ - para obter o controle de toda a produção, porém nessa etapa houve a maior dificuldade. Não foi encontrado no estado uma instituição ou universidade que tivesse uma mufla que chegasse a $800 C^{\circ}$ para realização da produção da CCA, portanto a opção foi comprar a CCA já pronta para dar prosseguimento.

A segunda etapa da coleta de dados, produção do concreto e moldagem de corpos de prova foi realizada no laboratório da Faculdade Pio Décimo, localizada na Av. Pres. Tancredo Neves, no 5655 - Jabutiana, Aracaju - SE, 49095-000, situado na latitude -10,925 e longitude -37,0807.

O cimento utilizado nessa pesquisa foi o que estava disponível no laboratório de materiais da faculdade e possui as seguintes características.

Marca: MIZU;

Tipo: Cimento Portland Composto (CP II F-32-RS);

Algumas características do cimento: melhor relação água/cimento, microestrutura mais compacta, menor permeabilidade, protege melhor a armadura, resistência ao ataque de sulfatos (RS).

O agregado miúdo utilizado no concreto estava disponível no laboratório, que após inspeção visual, foi verificado que correspondia a todos os requisitos exigidos na Norma. Para a confecção do concreto foi necessário peneirar o agregado (Figura 2). 
Figura 2: Agregado miúdo sendo peneirado

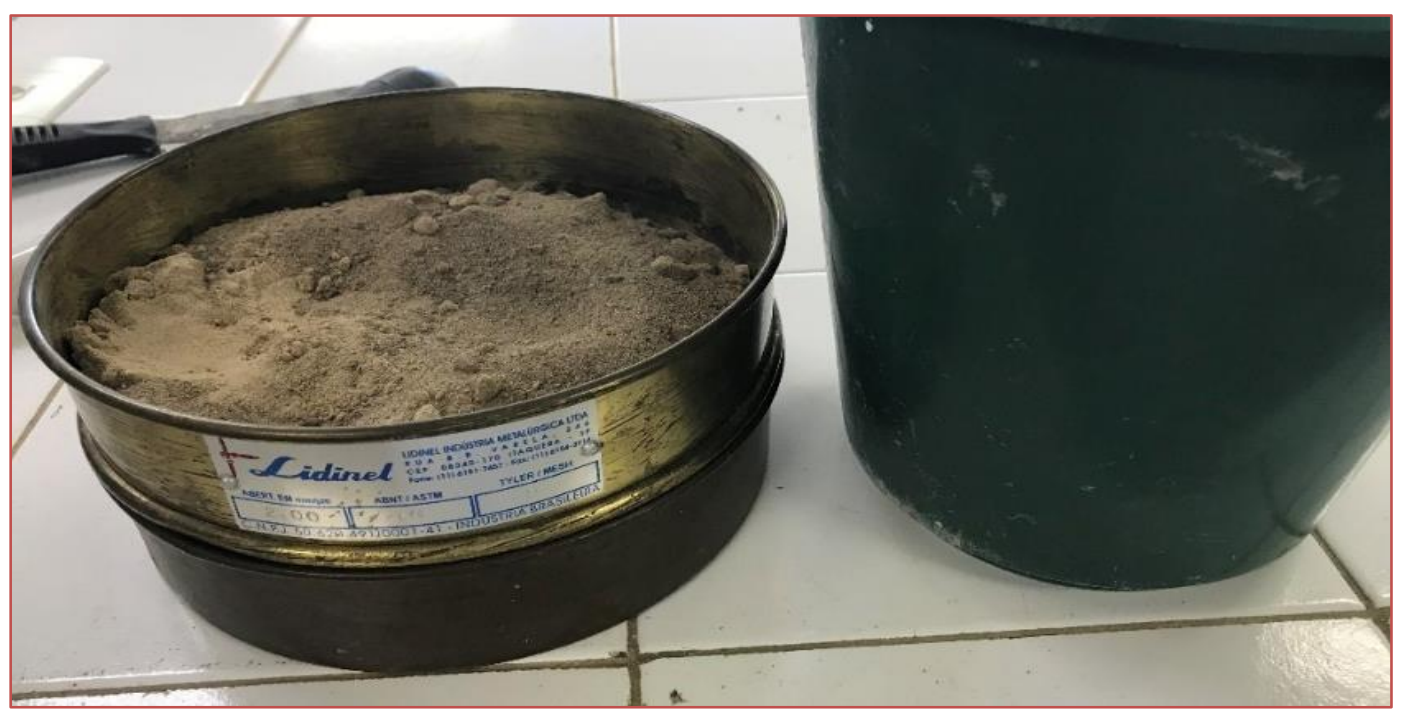

Fonte: autor (2019).

0 agregado graúdo também foi adquirido no laboratório de materiais da Faculdade. Como o experimento utilizou corpos de prova com a medida de 10x20, a brita atendeu às Normas para o processo de produção do concreto. Por precaução, o agregado graúdo foi lavado antes de ser utilizado, evitando assim, uma possível contaminação por sais e/ou outros materiais invisíveis a olho nu.

A cinza de casca de arroz (CCA) utilizada foi processada pela TERRAVIVA, localizada na cidade de São Pedro de Alcântara, Santa Catarina (Figura 3).

Figura 3: Cinza da Casca de Arroz

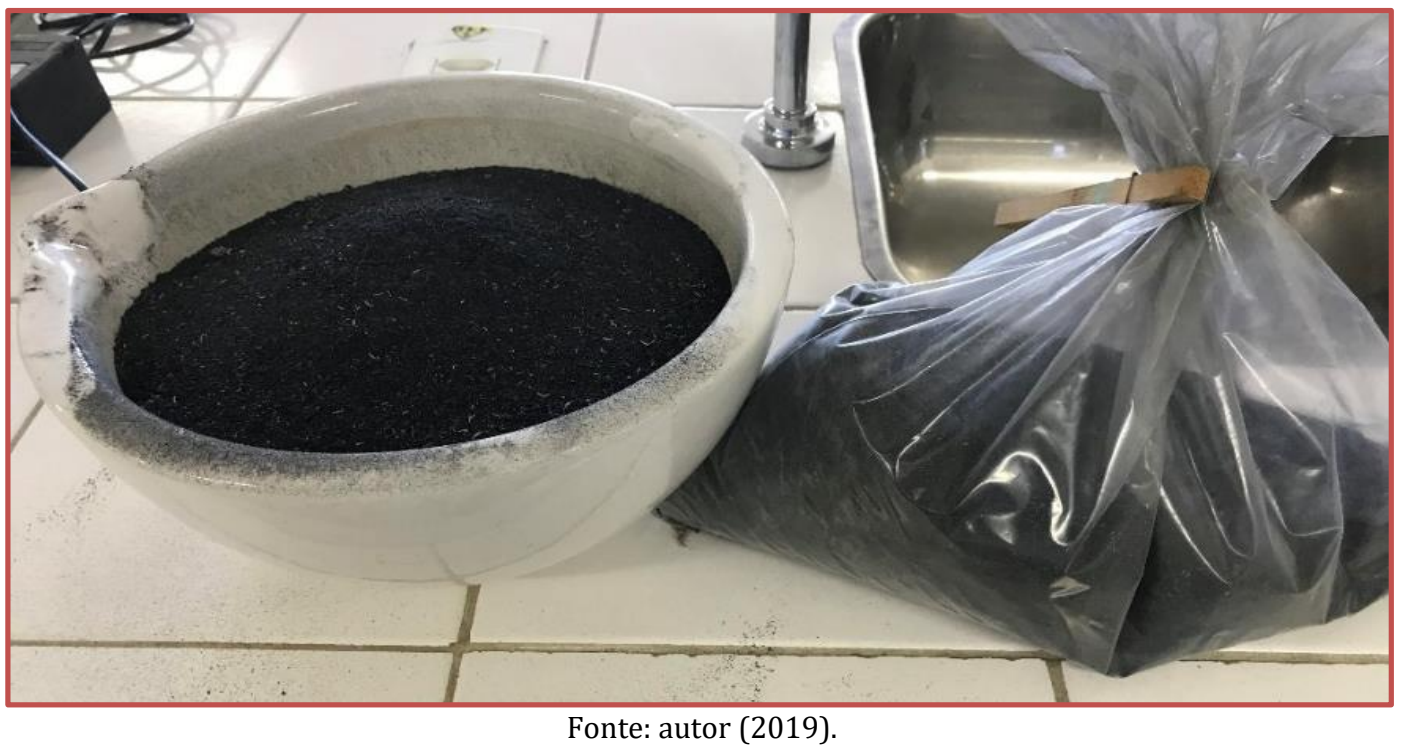

A água usada no estudo, caracteriza-se como potável, fornecida pelo Companhia de Saneamento de Sergipe - DESO, atendendo a todos requisitos básicos de qualidade, para que não comprometa a produção do concreto.

Para a produção do concreto, o traço utilizado foi o 1:2,36:3,69:0,5 com relação água/cimento de 0,55, 0568, 0,586 e 0,60 respectivamente, traço esse aplicado por Blatt (2016). 0 traço foi adaptado utilizando com a substituição de 5\% de cimento por CCA, moldados com abatimento (5CCA), com substituição de $10 \%$ do cimento por CCA moldados com abatimentos (10CCA) e com substituição de 15\% do cimento por 
CCA com abatimento controlado (15CCA), comparando estas com mistura de concreto sem adição de CCA (Tabela 1).

Tabela 1 - Quantidade de material para moldagem

\begin{tabular}{c|c|c|c|c|c|c}
\multirow{2}{*}{ TRAÇO } & \multirow{2}{*}{ a/c } & Cimento & CCA & Areia & Brita & Água \\
\hline & 0,55 & 341,66 & - & 807,6 & 1261,26 & 187,91 \\
\hline REF & 0,568 & 324,58 & 17,08 & 807,6 & 1261,26 & 194,40 \\
\hline $10 \%$ CCA & 0,586 & 307,49 & 34,17 & 807,6 & 1261,26 & 200,21 \\
\hline $15 \%$ CCA & 0,60 & 290,41 & 51,25 & 807,6 & 1261,26 & 206,02 \\
\hline
\end{tabular}

Para a produção do concreto foram realizados alguns cálculos em cima do traço principal do concreto, para saber a quantidade de materiais ideal utilizados para o preenchimento de 2 corpos de provas $10 \times 20 \mathrm{~cm}$ (Tabela 2).

Tabela 2 - Quantidade de material para confecção de dois corpos de prova 10 x 20

\begin{tabular}{c|c|c|c|c|c|c}
\multirow{2}{*}{ TRAÇO } & a/c & \multicolumn{7}{c}{ MATERIAIS $\left(\mathrm{kg} / \mathrm{m}^{3}\right)$} \\
\cline { 4 - 7 } & & Cimento & CCA & Areia & Brita & Água \\
\hline REF & 0,55 & 1,073 & - & 2,536 & 3,96 & 0,59 \\
\hline $15 \%$ CCA & 0,60 & 0,912 & 0,161 & 2,536 & 3,96 & 0,647 \\
\hline $10 \%$ CCA & 0,586 & 0,966 & 0,107 & 2,536 & 3,96 & 0,629 \\
\hline $5 \%$ CCA & 0,568 & 1,019 & 0,054 & 2,536 & 3,96 & 0,610 \\
\hline
\end{tabular}

Em seguida após saber a quantidade exata dos materiais, os mesmos foram separados e pesados (Figura 4).

Figura 4: Pesagem e dosagem do concreto.
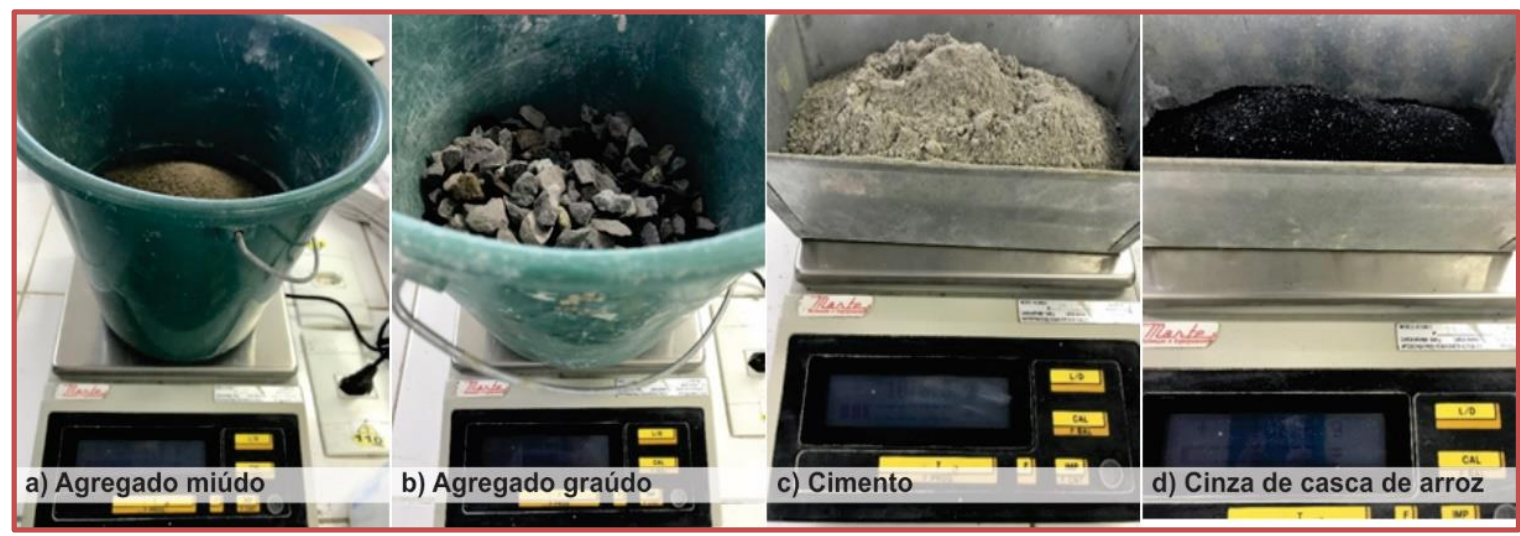

Fonte: autor (2019).

Dando continuidade no processo de produção do concreto, para a confecção dos corpos de prova foi utilizada uma argamassadeira (Figura 5), fornecida pela Faculdade Pio Décimo, onde foi depositado todos 
os agregados necessários para os traços com CCA. A ordem de deposição foi cimento, areia e cinza misturados na argamassadeira durante 30 segundos, e em seguida a adição de água, misturando tudo por dois minutos até sua homogeneização.

Após esse processo a mistura foi transferida para um balde, para adição do agregado graúdo; para uma melhor homogeneização utilizou-se uma espátula de aço.

Figura 5: Argamassadeira

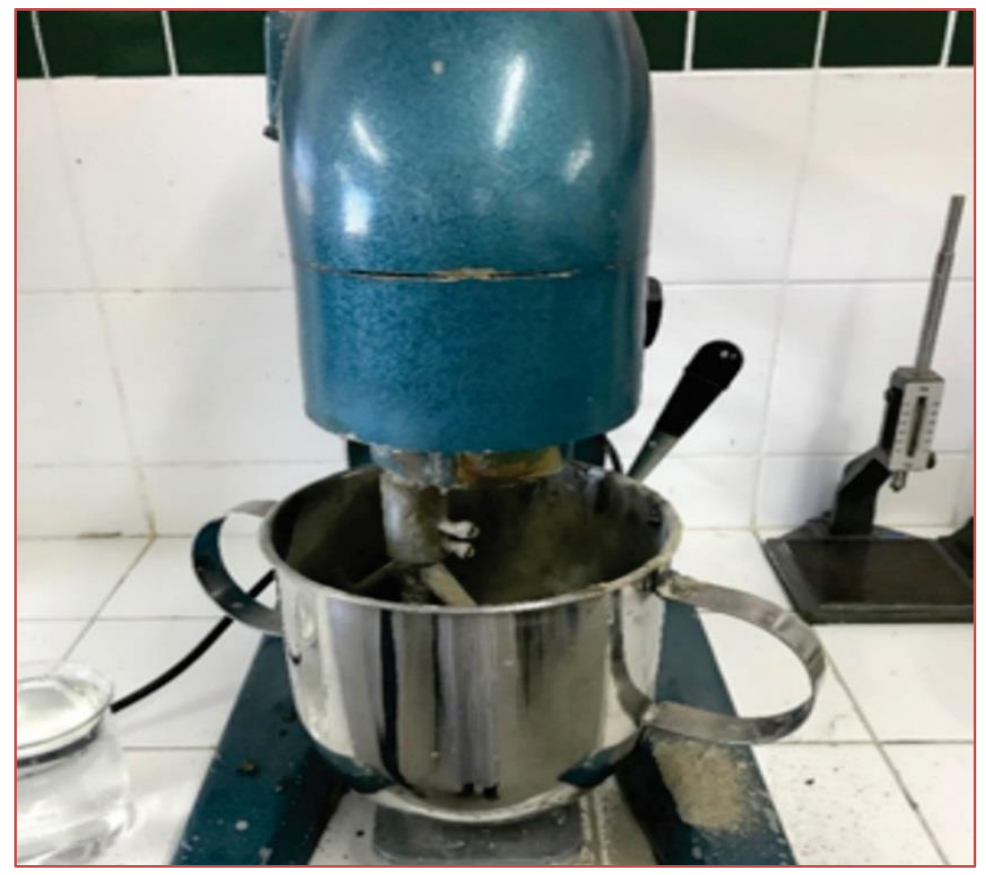

Fonte: autor (2019).

A relação água cimento a/c utilizada para amassamento foi de 0,55; 0,60; 0586 e 0,568, para os traços REF, 15\% CCA, 10\% CCA e 5\% CCA respectivamente, onde foi adaptado do traço de Blatt (2016). Durante a produção do concreto regulou o controle de água para atingir uma trabalhabilidade ideal para o concerto. Durante a produção foi observado que, os traços com CCA, o concreto perde parte da sua plasticidade, ficando pouco trabalhável (seco). No processo de homogeneização na argamassadeira foi necessário adicionar mais água no concreto, causando assim uma provável perda na resistência do concreto.

Os corpos de prova foram moldados com o preenchimento dos moldes cilíndricos, de dimensões 10x20 cm. 0 preenchimento se deu através de duas camadas uniformes de concreto e 12 golpes para compactação de cada camada conforme a NBR 5738/2015 (Figura 6). Na (Figura 7) ilustra-se o processo realizado para adensamento das amostras.

Figura 6: Número de camadas e golpes para moldagem dos corpos de prova

\begin{tabular}{|c|c|c|c|c|}
\hline \multirow{2}{*}{$\begin{array}{c}\text { Tipo de } \\
\text { corpo de } \\
\text { prova }\end{array}$} & $\begin{array}{c}\text { Dimensão } \\
\text { básica } \\
(\text { d })\end{array}$ & \multicolumn{2}{|c|}{$\begin{array}{c}\text { Número de camadas em função } \\
\text { do tipo de adensamento }\end{array}$} & \multirow{2}{*}{$\begin{array}{c}\text { Número de golpes para } \\
\text { adensamento manual }\end{array}$} \\
\cline { 3 - 4 } & mm & Mecânico & Manual & 12 \\
\hline \multirow{5}{*}{ Cilindrico } & 100 & 1 & 2 & 25 \\
& 150 & 2 & 3 & 50 \\
& 200 & 2 & 4 & 75 \\
& 250 & 3 & 5 & 100 \\
\hline & 300 & 3 & 6 & - \\
\hline
\end{tabular}

Fonte: NBR 5738/2015. 
Figura 7: Moldagem dos corpos de prova

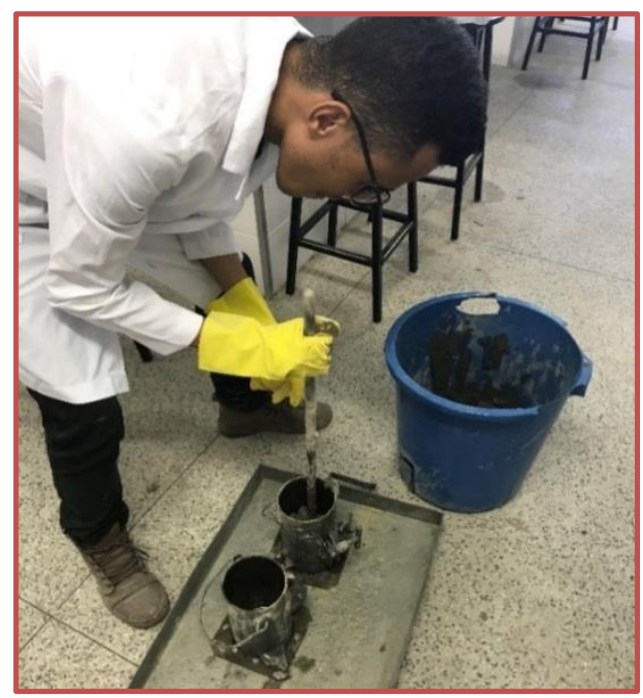

Fonte: autor (2019).

Foram moldados 24 corpos de provas, após o encerramento da moldagem, os corpos de prova ficaram expostos à temperatura ambiente nas primeiras 24 horas (Figura 8). Posteriormente foram desmoldados e imersos em uma caixa d'água, onde permaneceram até as datas dos ensaios de compressão axial conforme determina a NBR 5738/2015.

Figura 8: Alguns dos corpos de prova após processo de moldagem

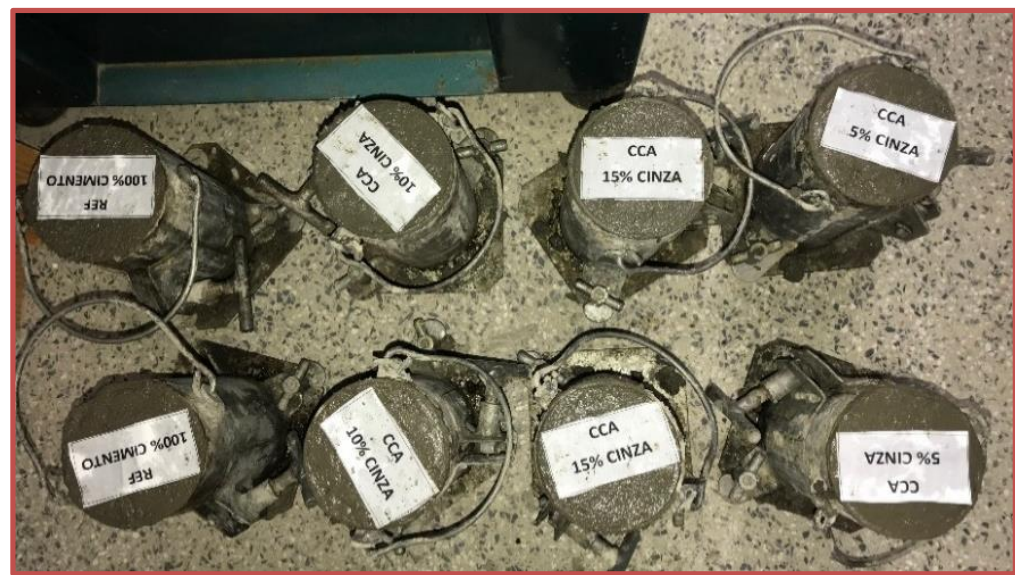

Fonte: autor (2019).

Após os corpos de prova permanecerem em processo de cura submerso por 3, 7, 14 dias, foi realizado um ensaio de compressão segundo a Norma Brasileira 5739/2007: Concreto - Ensaio de Compressão de corpos-de-prova cilíndricos. Para cada idade de cura foram submetidos 2 corpos de prova aos ensaios, realizados no Centro de Educação e Tecnologia Integrado da Construção Civil - CETICC.

Para o processo de resistência à compressão, este foi realizado de acordo com a NBR5739/2007. Para tal foi utilizado no ensaio uma prensa de rompimento de bloco da marca EMIC modelo PC-100, Capacidade 101,97 T, disponível no Laboratório do CETICC (Figura 9). 
Figura 9: Conjunto de rompimento de corpo de prova

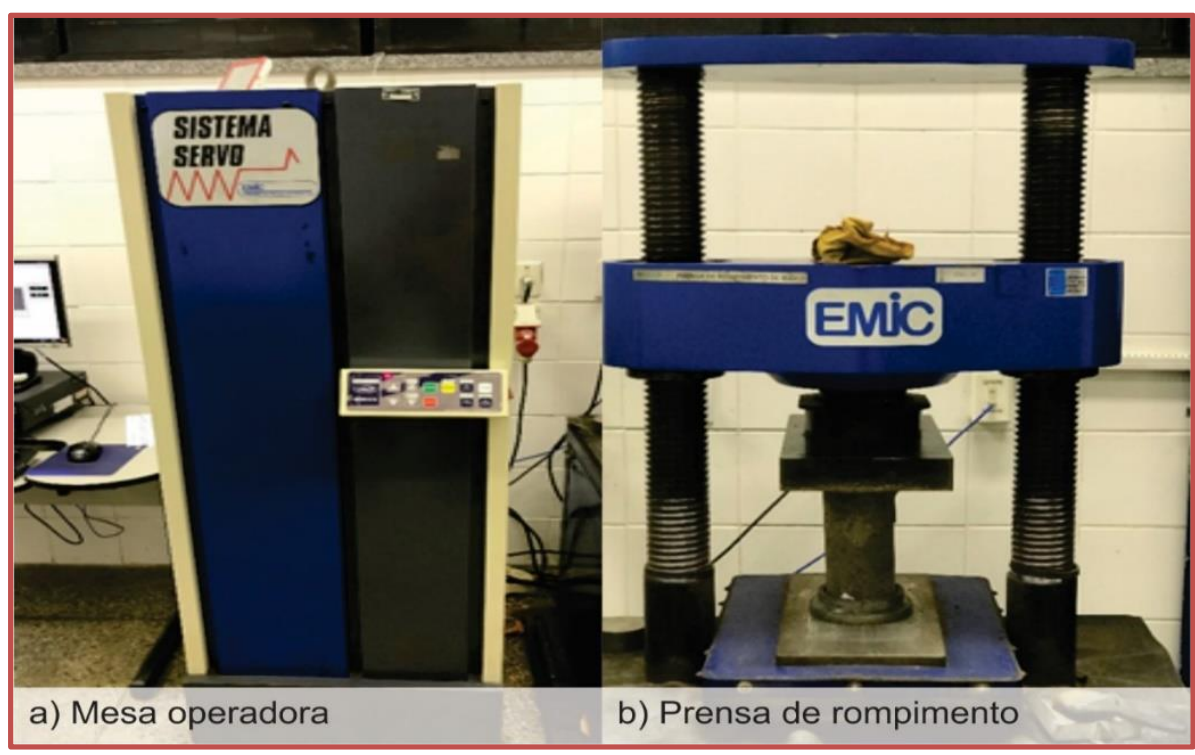

Fonte: autor (2019)

De acordo com a norma, o corpo de prova deve estar centralizado na câmara, de modo que o seu eixo fique alinhado com o da câmara, para que a resultante das forças passe pelo seu centro e assim atinja a força máxima que o corpo de prova resiste até o rompimento. Após este processo é aplicada a Equação 1.

$$
f c=\frac{4 F}{\pi x D^{2}} \quad \text { Equação (1) }
$$

Onde:

fc: é a resistência à compressão, em MPa;

F: é a força máxima alcançada, em Newtons;

D: é o diâmetro do corpo-de-prova em mm.

Para a análise de dados e para realizar as comparações e resultados foi utilizado software Excel para construção de gráficos e tabelas que melhoram a forma de interpretar os dados obtidos no ensaio de resistência a compressão axial.

A análise de dados foi realizada com base nos resultados obtidos no experimento realizados no laboratório. Através dele pode-se analisar se as propriedades do corpo de prova de concreto com cinza de casca de arroz e diferentes quantidades de água possuem características e desempenho compatível ou similar aos coletados nos corpos de provas referência com $100 \%$ de cimento na sua composição.

\section{RESULTADOS E DISCUSSÃO}

Os testes realizados em laboratório seguiram as respectivas normas da ABNT para efetuar uma comparação entre os resultados obtidos, e saber se há uma boa resistência no concreto com a adição de cinza de casca de arroz como parte parcial do cimento. 0 rompimento dos corpos de prova resultou em resistências diferentes como já era esperado. Os valores de resistência a compressão apresentaram entre 4,35 e 11,40 Mpa (Tabela 3). 
Tabela 3 - Rompimento do corpo de prova no terceiro dia

\begin{tabular}{c|c|c|c|c} 
TRAÇO & $\begin{array}{c}\text { QTD DE } \\
\text { AMOSTRAS }\end{array}$ & MÉDIA (MPa) & $\begin{array}{c}\text { DESVIO PADRÃO } \\
(\mathrm{MPa})\end{array}$ & $\begin{array}{c}\text { COEFICIENTE DE } \\
\text { VARIAÇÃO (\%) }\end{array}$ \\
\hline REF & 2 & 11,40 & 0,57 & 0,050 \\
\hline $15 \%$ CCA & 2 & 4,35 & 0,07 & 0,016 \\
\hline $10 \%$ CCA & 2 & 5,70 & 0,42 & 0,074 \\
\hline $5 \%$ CCA & 2 & 8,10 & 0 & 0,000 \\
\hline
\end{tabular}

Na (Figura 10) está a representação gráfica obtido através da média das amostras para os corpos de prova submetidos ao ensaio de resistência à compressão axial com cura de 3 dias.

Figura 10: Resistência à compressão axial aos 3 dias

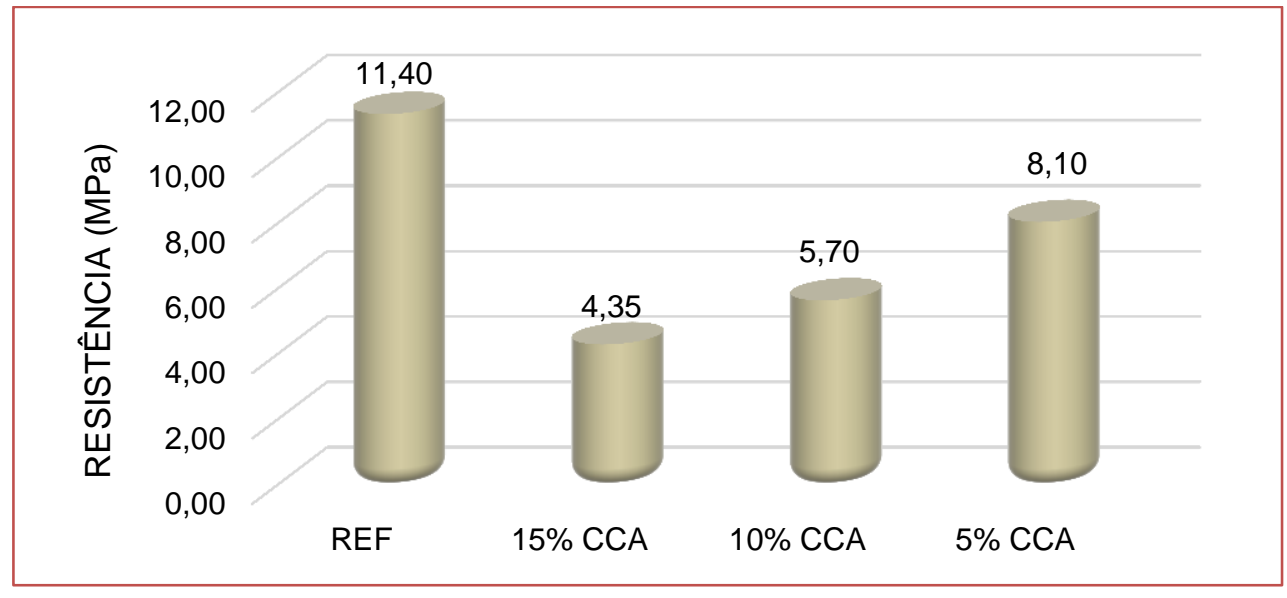

Fonte: autor (2019)

Descrição: REF - Traço Base - Rompido no terceiro dia; 15\% CCA - Traço Adicionado de 15\% Cinza de Casca de Arroz; 10\% CCA - Traço Adicionado de 10\% Cinza de Casca de Arroz; 5\% CCA - Traço Adicionado de 5\% Cinza de Casca de Arroz.

Na (Figura 10) onde se realizou o primeiro dia de rompimentos de corpos de provas, mostra a grande perda de resistência entre os traços. No REF traço base o que obteve uma maior resistência atingindo $11,40 \mathrm{MPa}$, já o traço $15 \%$ CCA obteve 4,35 MPa com perda de $62 \%$ em relação ao traço base, sendo o que obteve maior perda de resistência. Com 10\% CCA obteve 5,70 MPa e uma perda de $50 \%$ em relação ao concreto base. Com 5\% CCA obteve 8,10 MPa, sendo a menor perda de resistência referente aos traços com adição de cinza de casca de arroz, perdendo $29 \%$ em relação ao traço base.

Ainda a partir da (Figura 10) podemos analisar que no rompimento inicial aos 3 dias, o traço base com $100 \%$ de cimento se mostrou o mais resistente seguido do 5\% CCA. Comparando ao de Blatt (2016), a resistência se mostrou bem menor, porém muitos fatores influenciaram na produção do concreto. Como houve um controle de água durante a produção do cimento e observou-se que a cinza consume maior quantidade de água que o traço base para obter uma boa trabalhabilidade. Esse fato acabou afetando a resistência, isso é explicado por Isaias (2011), onde ele cita que o aumento de água no concreto acarreta em uma maior quantidade de poros na estrutura e consequentemente decréscimo na resistência.

Pode-se notar ainda que à medida que aumenta a quantidade de CCA na amostra diminui-se a resistência, mencionando novamente Blatt (2011), durante a realização de sua pesquisa ela comprovou que a utilização de aditivos junto ao traço com utilização de CCA obteve um resultado um pouco maior que o traço base na resistência a compressão ao terceiro dia, onde o aditivo ajudou obter um consumo mais considerável de água, mas não houve interferência no fator a/ac. 
Silva (2007) em sua pesquisa cita que adições pozolânicas como a CCA aumentam de forma expressiva a resistência à compressão durante todas as idades de cura do concreto, explicada pelo refinamento de poros e grãos. Porém em contrapartida Meira (2009) menciona que pelo efeito pozolânico causado durante a sua reação, a cinza de casca de arroz reage com o CH formando C-S-H. Essa reação por ser mais lenta que a reação de hidratação do C3S do cimento Portland, apresenta um ganho de resistência mais lento (MEIRA, 2009).

Na Tabela 4 e Figura 11 estão a representação gráfica obtido através da média das amostras para os corpos de prova submetidos ao ensaio de resistência à compressão axial com cura de 7 dias.

Tabela 4 - Rompimento do corpo de prova no sétimo dia

\begin{tabular}{c|c|c|c|c}
\hline \multirow{2}{*}{ TRAÇO } & $\begin{array}{c}\text { QTD DE } \\
\text { AMOSTRAS }\end{array}$ & MÉDIA (MPa) & $\begin{array}{c}\text { DESVIO PADRÃO } \\
(\mathrm{MPa})\end{array}$ & $\begin{array}{c}\text { COEFICIENTE DE } \\
\text { VARIAÇÃO (\%) }\end{array}$ \\
\hline REF & 2 & 14,40 & 0 & 0,000 \\
\hline $15 \%$ CCA & 2 & 7,43 & 0,95 & 0,129 \\
\hline $10 \%$ CCA & 2 & 6,98 & 0,32 & 0,046 \\
\hline $5 \%$ CCA & 2 & 9,45 & 0,95 & 0,101 \\
\hline
\end{tabular}

Figura 11: Resistência à compressão axial aos 7 dias

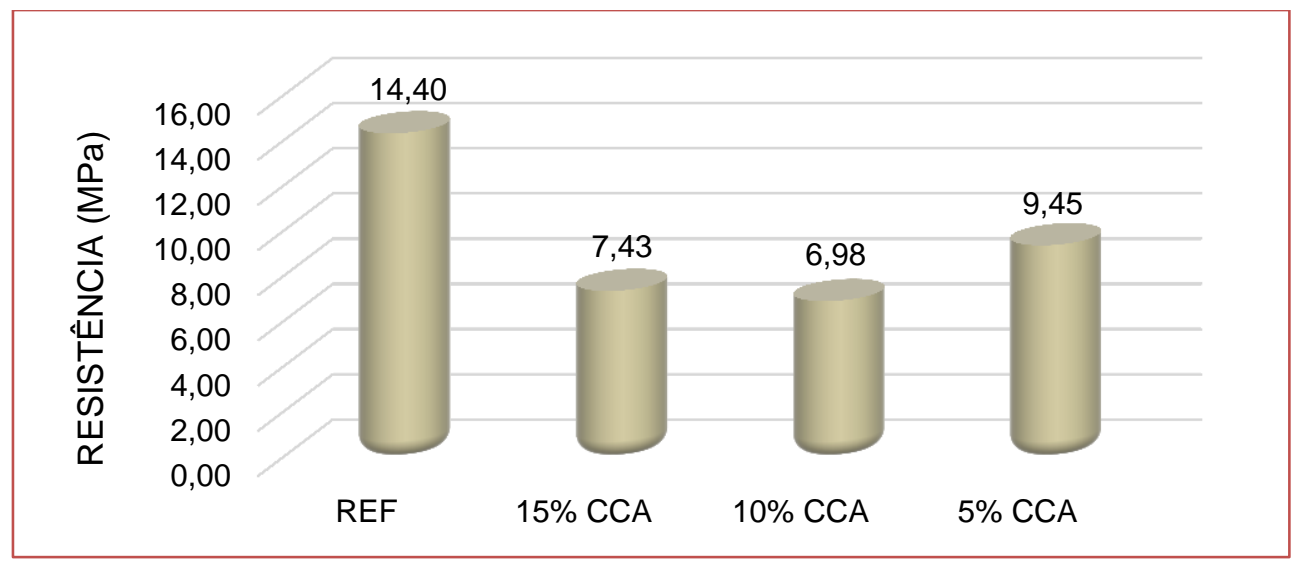

Fonte: autor (2019)

Descrição: REF - Traço Base - Rompido no terceiro dia; 15\% CCA - Traço Adicionado de 15\% Cinza de Casca de Arroz; 10\% CCA - Traço Adicionado de 10\% Cinza de Casca de Arroz; 5\% CCA - Traço Adicionado de 5\% Cinza de Casca de Arroz.

Para idade de 7 dias (Figura 11), podemos observar que houve uma pequena mudança referente ao traço que obteve uma perda de resistência maior, não sendo tão grande quanto referente ao rompimento de 3 dias. 0 traço REF continuou sendo o de maior resistência com 14,40 Mpa, seguido novamente do 5\% CCA com uma resistência de 9,45 $\mathrm{MPa}$, porém houve um aumento na sua perda de resistência quando comparado ao traço REF, foi para 34\% de perda. Já o de 10\% CCA obteve uma resistência de 6,98 MPa e uma perda de $52 \%$ sendo agora o que obteve a maior perda. 0 traço de 15\% CCA ficou com uma resistência de 7,43 MPa e 48\% de perda em relação ao concreto base um pouco abaixo dos 10\% CCA.

Com o aumento de CCA na composição, observa-se um desenvolvimento mais tardio da resistência à compressão das misturas à medida que cresce a fração de CCA nas primeiras idades (3 e 7 dias), valores significativamente inferiores quando comparados à mistura de referência.

Mehta e Monteiro (1994) classificam a CCA residual como sendo uma pozolana pouco reativa, e sugerem que este material deve ser finamente moído para desenvolver certa atividade pozolânica. Em uma pesquisa Meira (2009) realizou um estudo onde usou traços da CCA sem moagem e moída. Fica 
comprovado que utilizando a CCA moída aos rompimentos de 7 dias obteve resistências um pouco maior, do que a CCA sem passar pelo processo de moagem, ele utilizou também o uso de aditivos para que se alcançassem a consistência e trabalhabilidade desejadas.

A Tabela 5 e Figura 12 estão representando as médias das amostras para os corpos de prova submetidos ao ensaio de resistência à compressão axial com cura de 14 dias.

Tabela 5 - Rompimento do corpo de prova no décimo quarto dia

\begin{tabular}{c|c|c|c|c}
\multirow{2}{*}{ TRAÇO } & $\begin{array}{c}\text { QTD DE } \\
\text { AMOSTRAS }\end{array}$ & MÉDIA (MPa) & $\begin{array}{c}\text { DESVIO PADRÃO } \\
\text { (MPa) }\end{array}$ & $\begin{array}{c}\text { COEFICIENTE DE } \\
\text { VARIAÇÃO (\%) }\end{array}$ \\
\hline REF & 2 & 14,55 & 2,62 & 0,189 \\
\hline $15 \%$ CCA & 2 & 10,15 & 0,64 & 0,063 \\
\hline $10 \%$ CCA & 2 & 8,60 & 0,00 & 0,000 \\
\hline $5 \%$ CCA & 2 & 11,75 & 4,88 & 0,415 \\
\hline
\end{tabular}

Nota-se que para a idade de 14 dias (Figura 12), os traços com adições de CCA já mostraram um bom aumento na sua resistência, aproximando-se mais ainda do traço REF que se manteve constante com a idade de 7 dias com um valor de 14,55 Mpa, seguido novamente do traço de 5\% CCA com um aumento na sua resistência bem próximo do traço base com 11,75 MPa e uma redução na sua perda para 19\%. Já o de 15\% CCA com 10,15 MPa, também obteve uma redução na sua perda de $48 \%$ para $30 \%$ comparando-se ao traço REF, o de 10\% CCA manteve-se novamente como o último havendo apenas um pequeno aumento na sua resistência para 8,60 MPa e uma pequena redução para $41 \%$ de perda.

Figura 12: Resistência à compressão axial aos 14 dias

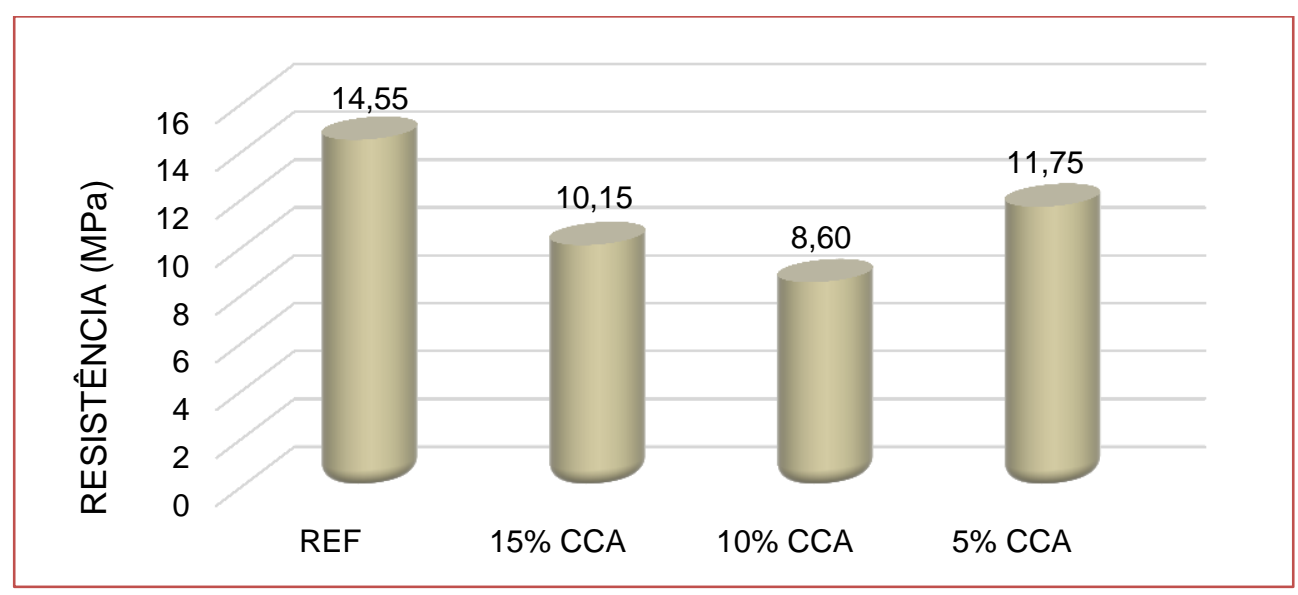

Fonte: autor (2019).

Descrição: REF - Traço Base - Rompido no terceiro dia; 15\% CCA - Traço Adicionado de 15\% Cinza de Casca de Arroz; 10\% CCA - Traço Adicionado de 10\% Cinza de Casca de Arroz; 5\% CCA - Traço Adicionado de 5\% Cinza de Casca de Arroz.

De maneira geral, o resultado obtido para os corpos de prova rompidos aos 14 dias mostra o raciocínio discutido nas idades anteriores, que descrevem o comportamento da resistência em idades mais avançadas pela incorporação de CCA. Nesta idade, a pozolana ainda está no seu processo de reação com o $\mathrm{CH}$ do cimento para formar o C-S-H.

Devido ao comportamento pozolânico da CCA, quando há substituição de parte do cimento pela pozolana, há uma diminuição na formação da fase do cimento C3S, responsável pela hidratação mais rápida no 
cimento. Além disso, a reação pozolânica da CCA é mais lenta. Este resultado está de acordo com diversas pesquisas desenvolvidas (DAL MOLIN, 1995; SENSALE, 2000).

Então para que se obtenha uma análise melhor da resistência do concreto com adições de CCA é ideal um estudo com o rompimento de corpo de prova com mais dias, 28, 77 e 90 dias e com o uso de aditivos para um melhor controle no processo do fator água/cimento, onde foi comprovado nessa mesma pesquisa, porém utilizando aditivos e com rompimento em idades mais avançadas (Meira, 2009; Blatt, 2016).

Outro fator importante para ser analisado é que para a adição apresentar uma alta reatividade, é necessário que a CCA tenha uma finura adequada e quantidades de $\mathrm{SiO} 2$ + $\mathrm{Al} 203$ em sua composição, e uma estrutura principalmente amorfa, que não é o caso da CCA estudada, pois como foi comprada não teve o controle ideal da temperatura durante a sua combustão, prejudicando sua pozolanicidade pela formação durante a sua fase cristalina as quais são menos reativas, em comparação com a sílica amorfa.

Para melhor visualização da evolução da resistência dos corpos de prova ao longo dos 14 dias, elaborou-se um gráfico unindo todas as idades (Figura 13).

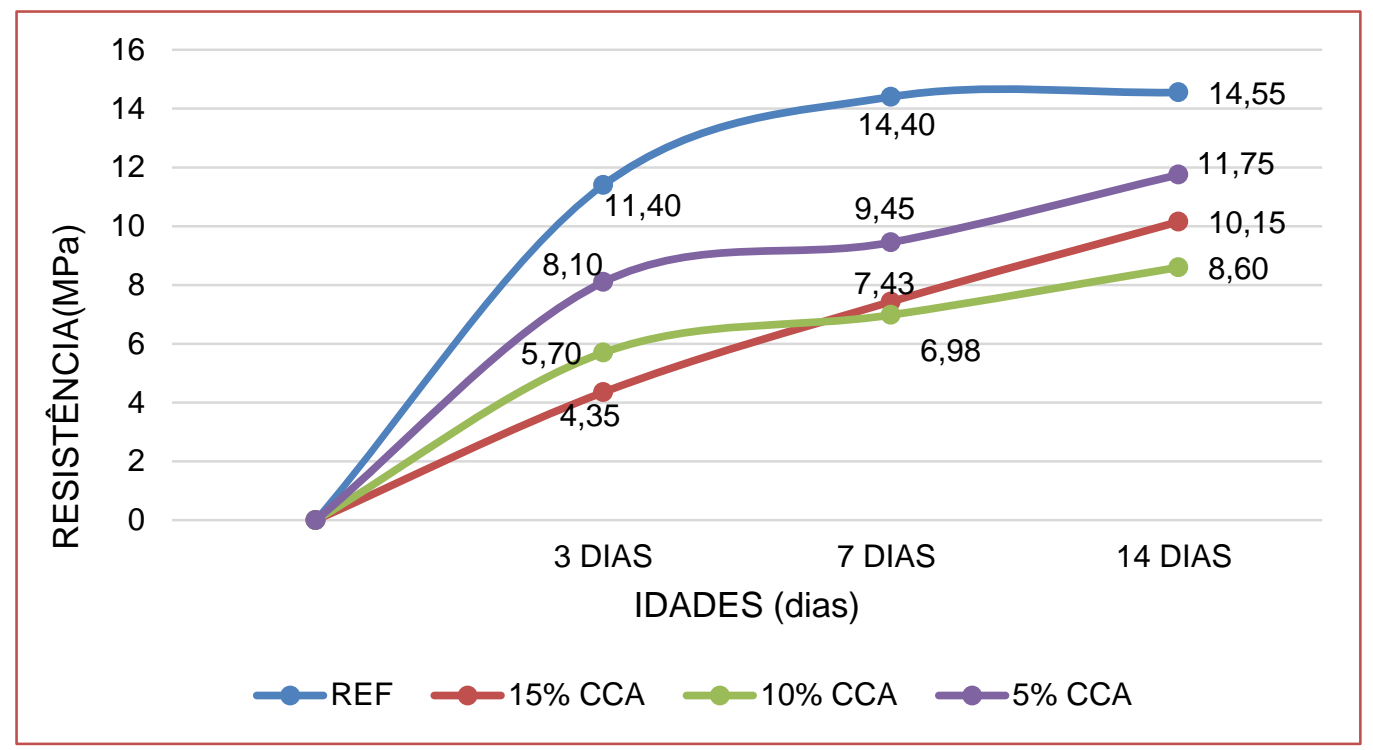

Figura 13: Resistência à compressão axial

Fonte: autor (2019).

\section{CONSIDERAÇÕES FINAIS}

O estudo realizado com a adição da cinza de casca de arroz como parte parcial do cimento obteve baixas resistências no concreto durante a cura de 3, 7 e 14 dias. A perda de resistência à compressão foi ocasionada, pela necessidade de acréscimo de água durante a produção do concreto, aumentando assim o fator a/c. Outro fator que influenciou foi a não utilização de aditivos para obtenção de um controle melhor do fator a/c.

Os concretos compostos com cinza de casca de arroz obtiveram perdas de resistência constante, conforme valores já demonstrados na análise de dados. A partir dos dados obtidos fica claro que o concreto feito no experimento não atende as necessidades básicas de resistência para sua utilização para fins estruturais. Outro fator que influenciou para perda de resistência à compressão, foi que a CCA durante a sua produção não obteve o controle de temperatura e o tempo ideal para a sua combustão, para manter os compostos químicos ideais para a hidratação do concreto.

O efeito pozolânico obtido durante a reação da cinza de casca de arroz com o hidróxido de cálcio formando o silicato de cálcio hidratado, tem uma reação mais lenta que a reação de hidratação do C3S do cimento Portland, apresentando um ganho de resistência mais lento, então como não foi realizado um processo de cura de 28 dias e dias mais avançados, não teve como os traços com adições de CCA demostrar um ganho no aumento na sua resistência. 
Recomenda-se que em estudos futuros utilize-se uma CCA com temperatura e tempo controlado durante o processo de combustão e com uma granulometria menor, utilizando aditivo durante a produção do concreto, e que sejam realizados testes de compressão axial com 28, 77 e 90 dias para obter um melhor desempenho das resistências dos traços com CCA.

\section{REFERÊNCIAS}

[1] ASSOCIAÇÃO BRASILEIRA DE NORMAS TÉCNICAS. NBR 5738. Concreto - Procedimento para moldagem e cura de corpos-de-prova cilíndricos. Rio de Janeiro: 2015.

[2] ASSOCIAÇÃO BRASILEIRA DE NORMAS TÉCNICAS. NBR 5739. Concreto - Ensaio de compressão de corposde-prova cilíndricos. Rio de Janeiro: 2007.

[3] BLATT, Gabriela, Análise da influência da cinza de casca de arroz nas propriedades do concreto. Universidade regional do noroeste do estado do rio grande do Sul - unijui, monografia apresentada no curso de Engenharia Civil. 2016.

[4] DAL MOLIN, D. C. C. (1995). Contribuição ao estudo das propriedades mecânicas dos concretos de alta resistência com e sem adições de micros sílica. São Paulo: Tese (Doutorado) - Escola Politécnica, USP.

[5] GURGEL, F. de L. A cultura do Arroz. 2012. Disponível em: http://www.ebah.com.br/content/ABAAAARc4AE/cultivo-arroz. Acesso em: abril de 2019.

[6] ISAIA, G. C. A água no concreto. Concreto: Ciência e Tecnologia. São Paulo, Instituto Brasileiro do Concreto (IBRACON), v. 1, 2011.

[7] MEHTA, P. K.; MONTEIRO, P. J. M. Concreto: estrutura, propriedades e materiais. São Paulo: Ed. Pini, 1994, $573 \mathrm{p}$.

[8] MEIRA, L. R. Propriedades mecânicas e retração do concreto com adição de cinza de casca de arroz natural, sem beneficiamento de moagem. Tese de Doutorado. Dissertação de Mestrado-Universidade Federal de Santa Maria. Santa Maria: 2009.

[9] SENSALE, G. R. B. (2000). Estudo comparativo entre as propriedades mecânicas dos concretos de alta resistência e convencionais com cinza de casca de arroz. Porto Alegre: programa de Pós-graduação em engenharia Civil. Tese (Doutorado). Universidade Federal do Rio Grande do Sul.

[10] SILVA, M. G.. Cimentos Portland com adições minerais: materiais de construção civil e princípios de ciência e engenharia de materiais. São Paulo: IBRACON, v. 1, p. 761-793, 2007.

[11] SOKOLOVICZ, B. C.; ISAIA, Geraldo C.; GASTALDINI; A.G.. Estudo da variabilidade técnica e econômica da cinza de casca de arroz residual e natural, sem beneficiamento, na produção de concreto estrutural. Estudo de protótipos. Penetração de cloretos. In: 51º Congresso Brasileiro de Concreto - IBRACON, 2009. 


\section{Capítulo 11}

Diagnóstico do abastecimento de água, coleta e tratamento do esgoto sanitário da cidade de Lagarto/SE

\section{Jislaine dos Santos Carvalho}

\section{Carlos Alfonso Alva Alvarado}

Resumo: 0 saneamento básico é essencial na vida dos seres humanos, em especial os sistemas de abastecimento de água e o esgoto sanitário. Esses dois sistemas formam um ciclo que poupa os mananciais, a agua bruta é captada e levada até a estação de tratamento, logo após é conduzida até os reservatórias para que seja feita a distribuição através das redes, é estimado que cerca de $80 \%$ da água consumida retorne pela rede coletora de esgoto para passar pelo tratamento e o efluente seja devolvido para o manancial com uma carga de DBO reduzida entre $60 \%$ e $80 \%$. 0 objetivo desse trabalho é diagnosticar os dois sistemas citados, além da qualidade, quantidade, oportunidades da água que se oferece para a população e quantificar o grau de satisfação. Nos últimos anos o saneamento no Brasil deu um salto significativo, em 2016 o abastecimento de água era de $83,3 \%$ nas residências, enquanto a coleta e tratamento de esgoto ainda possuía um déficit considerável, apenas 51,9\% apresentava cobertura. Na cidade de Lagarto o abastecimento de água possui um índice de $97,7 \%$, porém ainda existe o agravante da elevada perda de água durante o fornecimento dos consumidores que é de $53,79 \%$ e isso contribui para o baixo consumo médio per capita. No esgoto sanitário a cidade possui um sistema que faz tratamento através de lagoa facultativa, com um índice de coleta de $11,48 \%$ e $100 \%$ de tratamento com uma eficiência de $61,3 \%$. A cidade está com a construção do restante do sistema de esgoto, para 2035 há uma estimativa de que a cidade esteja com $100 \%$ de coleta e tratamento. Os dois sistemas possuem dificuldades, o de água possui um déficit pelas perdas e o de esgoto é insuficiente e ineficiente.

Palavras-chave: saneamento, abastecimento de água, esgoto sanitário. 


\section{INTRODUÇÃO}

O saneamento básico é um fator de extrema importância para o crescimento econômico e social de uma nação. Os serviços de abastecimento de água e coleta e tratamento de esgoto melhoram a qualidade de vida da população, principalmente na saúde infantil, reduzindo assim o índice de mortalidade, melhoria na educação, expansão do turismo, valorização de imóveis, e principalmente na despoluição dos rios e preservação dos recursos hídricos.

A situação do esgoto sanitário é caracterizada pelo descaso das atividades de saneamento causando sérios problemas sociais, econômicos e ambientais. A falta de condições de saneamento adequado, muitas vezes aliada à prática de educação sanitária e ambiental, resulta na incidência de doenças que prejudicam o rendimento do trabalho, reduz a qualidade de vida da população e crescimento da mortalidade infantil.

Não é interessante oferecer para a sociedade somente água tratada sem antes preocupar-se com o seu destino após o uso. Vale ressaltar a importância dos meios que fazem o sistema de esgotamento sanitário funcionar na sua plenitude, desde a coleta realizada pelos ramais prediais até a disposição final.

O saneamento básico tem como objetivo melhorar a qualidade de vida, posteriormente, produzir transformações, a discussão sobre abastecimento de água, coleta e tratamento de esgoto, além do aspecto relevante, reveste-se de importância para o meio ambiente. Nesse contexto, a análise do saneamento é um desafio para a população e pode ser um início para a transformação da qualidade de vida.

Este trabalho de conclusão de curso teve como objetivo diagnosticar os serviços de abastecimento de água e coleta e tratamento de esgoto sanitário da cidade de Lagarto. Além da qualidade, quantidade e oportunidades da água que se oferece a população e quantificar o grau de satisfação da população com a DESO de acordo com os serviços.

\section{METODOLOGIA}

A presente pesquisa apresenta dados obtidos em Lagarto, município brasileiro situado na Região Nordeste e mesorregião agreste sergipano. Encontra-se no centro-oeste do estado, Lagarto (Figura 1), a maior cidade do interior com uma população estimada para 2018 de 103.576 habitantes pelo Instituto de Geografia e Estatística (IBGE). Os municípios limítrofes são Simão Dias, Riachão do Dantas, Salgado, Itaporanga, Boquim, Campo do Brito, São Domingos e Macambira. A cidade fica localizada a $75 \mathrm{~km}$ de distância da capital, sendo o terceiro mais populoso do estado.

Figura 1: Destaque da cidade de lagarto dentro do estado de Sergipe.

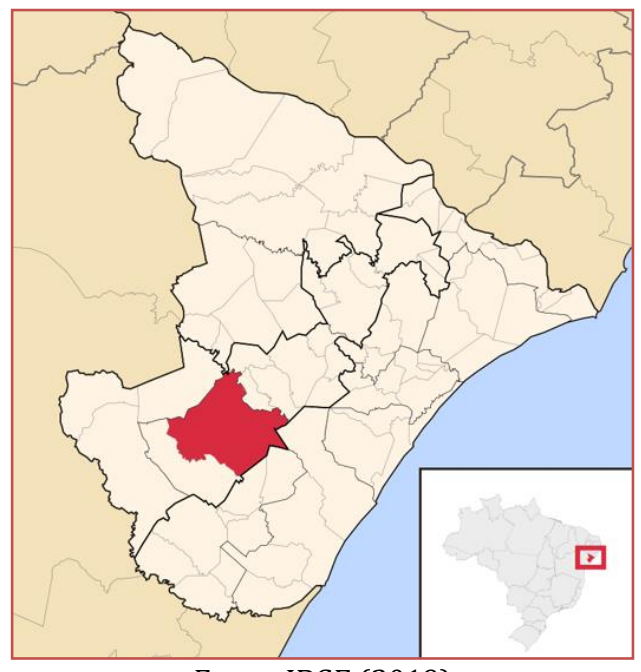

Fonte: IBGE (2019).

Na geografia, fica localizado há uma latitude de 1055’02"S e uma longitude de 3739’00"0, com uma altitude 183 metros e um clima tropical. Seu território compreende uma área de 968,921 $\mathrm{km}^{2}$ e densidade de $97,84 \mathrm{hab} / \mathrm{km}^{2}$. A hidrografia é composta pelos rios Vaza-Barris, Piauí, Jacaré, Piauitinga de Cima, 
Machado e Caiça, entre alguns riachos. Possui riquezas minerais exploradas e inexploradas como calcário, argila, mármore, enxofre e pedras de revestimento.

Com uma população mista, mas a predominância é portuguesa. No censo de 2010 mostra que $48,46 \%$ da população reside na zona rural, já os $51,54 \%$ reside na zona urbana. A população feminina é de $50,98 \%$ e a masculina de 49,02\%, possuindo também 33.532 domicílios.

Os procedimentos foram de três tipos: o bibliográfico, o documental e o de campo. A pesquisa bibliográfica permite conhecer o que já estudou sobre o assunto e utiliza livros e artigos científicos, o documental recorre a fontes mais diversificadas e sem tratamento, tais como, tabelas estatísticas, relatórios, documentos oficiais, etc. Já a pesquisa de campo é caracterizada por investigações que se realiza junto a pessoas (GERHARDT e SILVEIRA, 2009).

Foi feita uma visita para solicitação de levantamento de dados sobre abastecimento de água e coleta e tratamento de esgoto da cidade de Lagarto no dia 27/02/2019 na Assessoria de Planejamento e Gestão Empresarial na concessionária DESO - Companhia de Saneamento de Sergipe, porém até o momento da realização da análise de dados ainda não obtinha nenhuma informação.

Consultadas as séries de dados do IBGE, como os dados a área de estudo da cidade de Lagarto. As séries de dados do SNIS e da ANA foram utilizadas para compor a pesquisa, já que os dados não foram cedidos pela DESO. Também foi utilizado o relatório final sobre a Bacia do Piauí e a Elaboração dos Planos das Bacias Hidrográficas dos Rios Japaratura, Piauí e Sergipe, ambos da SEMARH.

0 trabalho de campo foi realizado no centro da cidade e nos bairros mais carentes, para que as pessoas respondessem como está o local onde vivem, nos quesitos de abastecimento de água e esgoto sanitário.

0 trabalho refere-se ao Saneamento Básico da cidade de Lagarto/SE, a pesquisa é baseada no sistema de abastecimento de água e esgoto sanitário. Para fazer análise dos dados foi utilizado o software Excel da empresa Microsoft na elaboração de tabelas e gráficos que contribuem para o entendimento dos dados: manancial de captação, tipo de tratamento, redes de distribuição em km de água, número de ligações domiciliares, perdas de água. Já para esgoto, rede de coleta em km, número de ligações, tipo de tratamento de esgoto e capacidade de tratamento, sistema atual (2013) e estimativa em 2035.

\section{RESULTADOS E DISCUSSÃO}

\subsection{CARACTERÍSTICAS DO SISTEMA INTEGRADO PIAUITINGA/DIONÍSIO MACHADO}

o município de Lagarto possui o abastecimento de água através da captação de águas superficiais/subterrâneos do Sistema Integrado Piauitinga/Dionísio Machado (Figura 2) que abastece mais duas cidades, Riachão do Dantas e Simão Dias, sendo responsável pela DESO.

Figura 2: Sistema de Abastecimento - Integrado Piauitinga/Dionísio Machado.

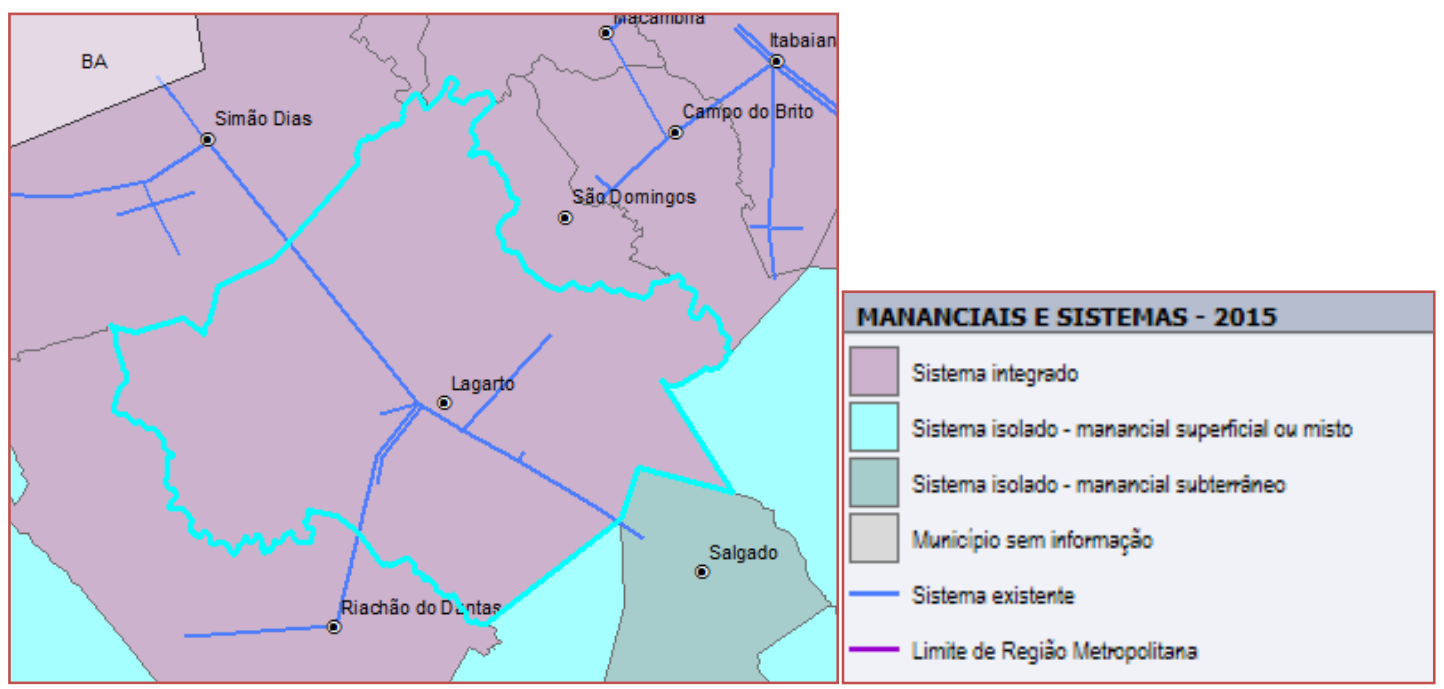

Fonte: BRASIL (2019). 


\subsubsection{MANANCIAL E CAPTAÇÃO}

O Sistema Integrado Piauitinga/Dionísio Machado possui 3 (três) mananciais. E nas condições de 2014 pode-se observar:

- A Barragem Dionísio Machado em Lagarto, o principal manancial do sistema, com uma vazão captada de $157 \mathrm{~L} / \mathrm{s}$. As águas desse manancial percorrem cerca de $4 \mathrm{~km}$, passam por 2 (duas) estações elevatórias de água bruta até chegar a ETA e são distribuídas para as outras cidades que compõe o sistema.

- No Rio Piauitinga a água é captada por uma barragem de nível no município de Salgado, com uma vazão de 172,8 L/s, percorrendo por uma adutora de 190 m diretamente para a ETA e após vai para um poço de sucção para ser distribuída para as cidades que compõe o sistema.

- Os 4 poços somam uma vazão de $82,76 \mathrm{~L} / \mathrm{s}$, passam por um tratamento de simples desinfecção e distribui para os municípios que compõe o sistema.

De acordo com o Atlas Brasil em estudo realizado pela Agência Nacional de água, Brasil (2010), no cenário de 2015 o município possuía uma demanda urbana de 179 L/s, uma situação satisfatória do sistema de abastecimento, até 2025 não haveria necessidade de investimento em água.

Na avaliação da oferta e demanda de água, a barragem Dionísio Machado tem uma contribuição na participação do abastecimento de Lagarto de $50 \%$, o Rio Piauitinga também de $50 \%$ e os 4 poços de Lagarto (salgado) + 3 poços (Pé da Serra) contribuem em menos de 1\%, ambos com uma situação satisfatória e distribuindo para as cidades de Riachão do Dantas e Simão Dias.

De acordo com Sergipe (2018), o Relatório Anual de Informações ao consumidor da DESO, até 2018 no abastecimento de Lagarto, Riachão do Dantas e Simão Dias foram acrescidos mais 3 (três) poços, sendo 2 (dois) em Salgado e 1 (um) no Pé da Serra do Qui.

\subsubsection{ESTAÇÃO DE ELEVATÓRIAS DE ÁGUA BRUTA E ADUTORA}

As estações elevatórias de água bruta são montadas com um conjunto de motor bomba, mantendo sempre uma de reserva. Na captação Piauitinga utiliza bombas submersível e na Barragem Dionísio machado há uma altura manométrica de 29 m.c.a, a Figura 3 mostra um trecho da adutora. As estações possuem as características citadas no Tabela 1.

Figura 3: Trecho da adutora que vem do reservatório para estação elevatória.

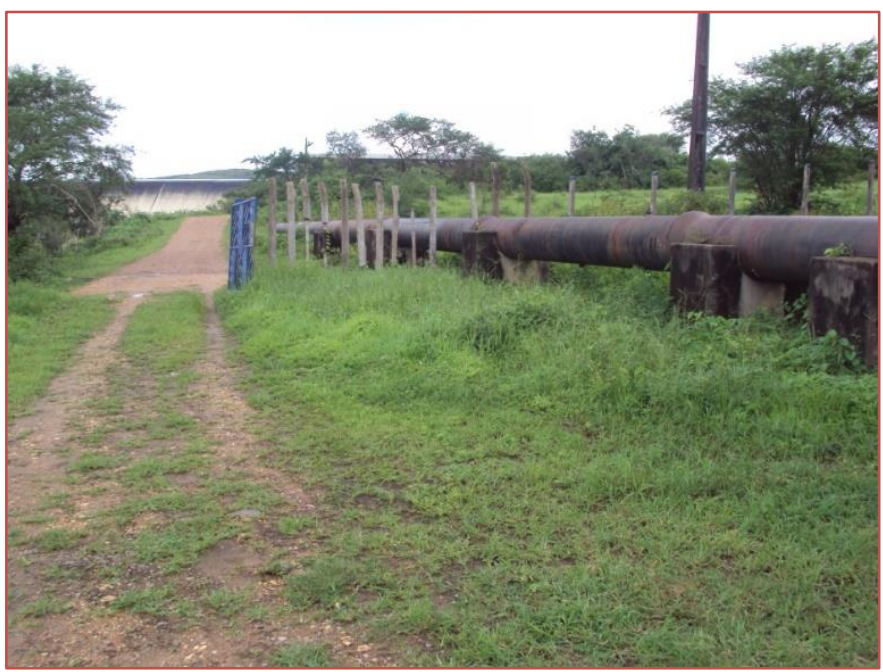

Fonte: SERGIPE (2014). 
Tabela 1: Características da estação de tratamento e adução.

\begin{tabular}{c|c|c|c|c|c} 
& $\begin{array}{c}\text { Número de } \\
\text { bombas }\end{array}$ & Vazão (L/s & $\begin{array}{c}\text { Potência } \\
(\mathrm{CV})\end{array}$ & $\begin{array}{c}\text { Diâmetro } \\
(\mathrm{mm})\end{array}$ \\
$\begin{array}{c}\text { Piauitinga } \\
\text { Barragem Dionísio } \\
\text { Machado }\end{array}$ & 3 & 55 & 20 & 400 & 190 \\
\hline \multicolumn{5}{c}{ Fonte: SERGIPE (2014) }
\end{tabular}

\subsubsection{TRATAMENTO}

A estação de tratamento Piauitinga possui capacidade para $110 \mathrm{~L} / \mathrm{s}$, localiza-se cerca de $200 \mathrm{~m}$ do local da captação de água bruta. 0 tratamento é realizado a partir da chegada de água bruta e feita a medição de vazão, inicia o processo de floculação, decantação, filtração e vai para o tanque de contato, passando pelos filtros e recebe o tratamento químico.

Já a estação de tratamento Lagarto é compacta, composta por filtros russos de fluxos ascendentes com capacidade de 160 L/s. Segundo Richter e Azevedo Netto (1991), o processo de fluxo ascendente possui a função de clarificar a água de baixa turbidez e matéria mineral existente, o filtro recebe a água bruta sem passar pelo processo de floculação e decantação, vai diretamente para a desinfecção e reservação/distribuição.

De acordo com Bernardo (2003), a filtração direta apresenta muitas vantagens por possuir menores unidades de mistura, sendo apenas de coagulação, floculação (nem sempre) e filtração. Uma outra vantagem é o baixo consumo de produtos químicos durante o tratamento.

\subsubsection{ESTAÇÃO DE ELEVATÓRIAS DE ÁGUA TRATADA E ADUTORA}

A estação elevatória-1 situa-se na área da estação de tratamento, próximo ao tanque de contato. A sala possui o conjunto de 3 motor bomba, sendo 1 de reserva, do tipo eixo horizontal com uma vazão de 367,2 $\mathrm{m}^{3} / \mathrm{h}$, altura manométrica de 148 m.c.a. e potência de $450 \mathrm{CV}$.

Na adutora da estação de tratamento-Lagarto o diâmetro é de $400 \mathrm{~mm}$ e contém as seguintes extensões:

Tramo 1: ETA-1 $\rightarrow$ Derivação para Colônia XIII: 6.098m

Tramo 2: Derivação para Colônia XIII/Cx. De passagem: 9.952 m

Tramo 3: Cx. de passagem/Lagarto: $6.180 \mathrm{~m}$

Já a ETA-2 possui:

- $\quad$ Recalque de elevação intermediária para Simão Dias através do conjunto de 2 motor bomba com uma vazão de $336,24 \mathrm{~m}^{3} / \mathrm{h}$, altura manométrica de 141 m.c.a. e potência de $300 \mathrm{CV}$.

- $\quad$ Recalque de elevação intermediária para Riachão do Dantas através do conjunto de 2 motor bomba com uma vazão de $50,9 \mathrm{~m}^{3} / \mathrm{h}$, altura manométrica de 130 m.c.a. e potência de $30 \mathrm{CV}$.

- Recalque de reservatório elevado de Lagarto através do conjunto de 2 motor bomba com uma vazão de $666 \mathrm{~m}^{3} / \mathrm{h}$, altura manométrica de 50 m.c.a. e potência de $200 \mathrm{CV}$.

\subsubsection{RESERVAÇÃO E DISTRIBUIÇÃO}

As águas que abastecem a cidade de Lagarto advindas dos mananciais do sistema recebem o tratamento por Filtro Russo, através da desinfecção e fluoretação. As águas da estação de tratamento de água Lagarto são distribuídas para 2 reservatórios que dividem a vazão da estação de tratamento de água para os municípios de Lagarto, Riachão do Dantas e Simão Dias.

De acordo com dados encontrados na base de dados do SNIS, em 2017 o município de Lagarto produzia um volume de água de 5.905,020 $\mathrm{m}^{3}$ /ano para um total de 84.444 habitantes, divididas em 53.623 residindo na área urbana e 30.818 na zona rural e um índice de atendimento de na área urbana de $97,70 \%$. 
Ainda existe uma extensão de rede de distribuição de 445,55 km, extensão de rede de água por ligação de 15,42 m/lig, o sistema era composto por 25.468 ligações ativas de água, sendo 25.378 micromedidas, um índice de hidrometração de 99,8\% e uma quantidade de 31.896 em ligações totais.

A Tabela 2 apresenta volumes micromedidos e a população abastecida pelo sistema de abastecimento de água que resulta no consumo médio per capita anual.

Tabela 2: Consumo per capita de Lagarto.

\begin{tabular}{c|c|c|c} 
Ano & População & $\begin{array}{c}\text { Volume consumido } \\
\left(\mathrm{m}^{3} / \mathrm{ano}\right)\end{array}$ & $\begin{array}{c}\text { Consumo per capita } \\
\text { (L/hab.dia) }\end{array}$ \\
2017 & 84.444 & 2.728 .940 & 87,88 \\
\hline 2016 & 84.082 & 2.716 .420 & 87,88 \\
\hline 2015 & 85.282 & 2.812 .070 & 90,44 \\
\hline 2014 & 85.096 & 2.807 .000 & 92,73 \\
\hline 2013 & 80.771 & 2.623 .000 & 90,77 \\
\hline \multicolumn{3}{c}{ Fonte: BRASIL (2019). }
\end{tabular}

Através das informações acima, ao longo dos últimos 5 anos, o consumo per capita do município não se aproximou do recomendado pela ONU (Organização das Nações Unidas) que é de $110 \mathrm{~L} / \mathrm{hab}$.dia, nem da média nacional que em 2016 foi de 154,1 L/hab.dia. Representando aproximadamente 57,03\% da média per capita nacional e $78,11 \%$ da média per capita do Nordeste que é o menor consumo do país com 112,5 L/hab.dia em 2016.

De fato, o baixo consumo de água na cidade ocorre em muitas situações da falta de água no sistema de abastecimento ao longo do ano, significando que a população necessita mais do que a disponibilização de água.

\subsubsection{PERDAS DE ÁGUA}

De acordo com os dados informados pela Série Histórica do SNIS, foi realizada a quantificação do índice perdas na distribuição no sistema de abastecimento de água. Foram analisados dados durante 5 anos, a Tabela 3 mostra as perdas entre 2013 e 2017.

Tabela 3: Perda de distribuição e faturamento.

\begin{tabular}{c|c|c}
\multirow{2}{*}{ Ano } & $\begin{array}{c}\text { Perda de } \\
\text { Distribuição (\%) }\end{array}$ & $\begin{array}{c}\text { Perda de Faturamento } \\
(\%)\end{array}$ \\
2017 & 53,79 & 40,5 \\
\hline 2016 & 53,71 & 40,08 \\
\hline 2015 & 51,80 & 38,22 \\
\hline 2014 & 55,76 & 43,94 \\
\hline 2013 & 54,39 & 42,73 \\
\hline \multicolumn{3}{|c}{} \\
\hline
\end{tabular}

Como é possível observar, no período de 2013 e 2017 o índice de perda de distribuição do sistema ficou quase constante, em 5 anos variou apenas na casa de $2 \%$, isso prova que não ouve melhoria no setor. 0 índice de perda de distribuição em 2017 foi de 53,79\%, ficando bem acima da média nacional que, segundo Oliveira et al., (2018) em 2016 foi de 38,01\%.

A redução desse índice se faz necessário, pois há um déficit na oferta de água tratada do município. Com a redução da perda, seria possível melhorar o atendimento e suprir melhor a demanda sem aumentar a produção.

Já para a perda de faturamento, também foi realizada a quantificação do índice de perda de faturamento no sistema de abastecimento de água. Novamente, foram analisados os últimos 5 anos, o quadro 5 mostra as perdas entre 2013 e 2017. Em 2017 o índice de perda foi de faturamento foi de 40,5\%, também permanecendo acima da média nacional que foi de $36,24 \%$. 
Pode-se observar que houve pequenas variações nos anos de 2013 e 2014, entre 2014 e 2015 houve uma pequena redução, não havendo continuidade. No ano seguinte, ela novamente deu um salto de quase $2 \%$ permanecendo constante em 2017.

De acordo com Pauli (2015), no Brasil o setor de saneamento apresenta vários problemas, com uma média de perda de água em aproximadamente $40 \%$ e em algumas empresas chegam até 60\%. 0 elevado índice reduz o faturamento das empresas e a capacidade de investir, sem contar a obtenção de financiamento, além de causar danos ao meio ambiente na busca de novos mananciais.

A Figura 4 apresenta uma perda de distribuição que ocorre frequentemente na cidade, podendo colocar em risco a saúde dos moradores, pois quando não há água na tubulação a pressão negativa dentro dela é muito grande, sugando uma grande parcela de esgoto para o seu interior e distribuindo para as residências.

Figura 4: Perda de água na distribuição

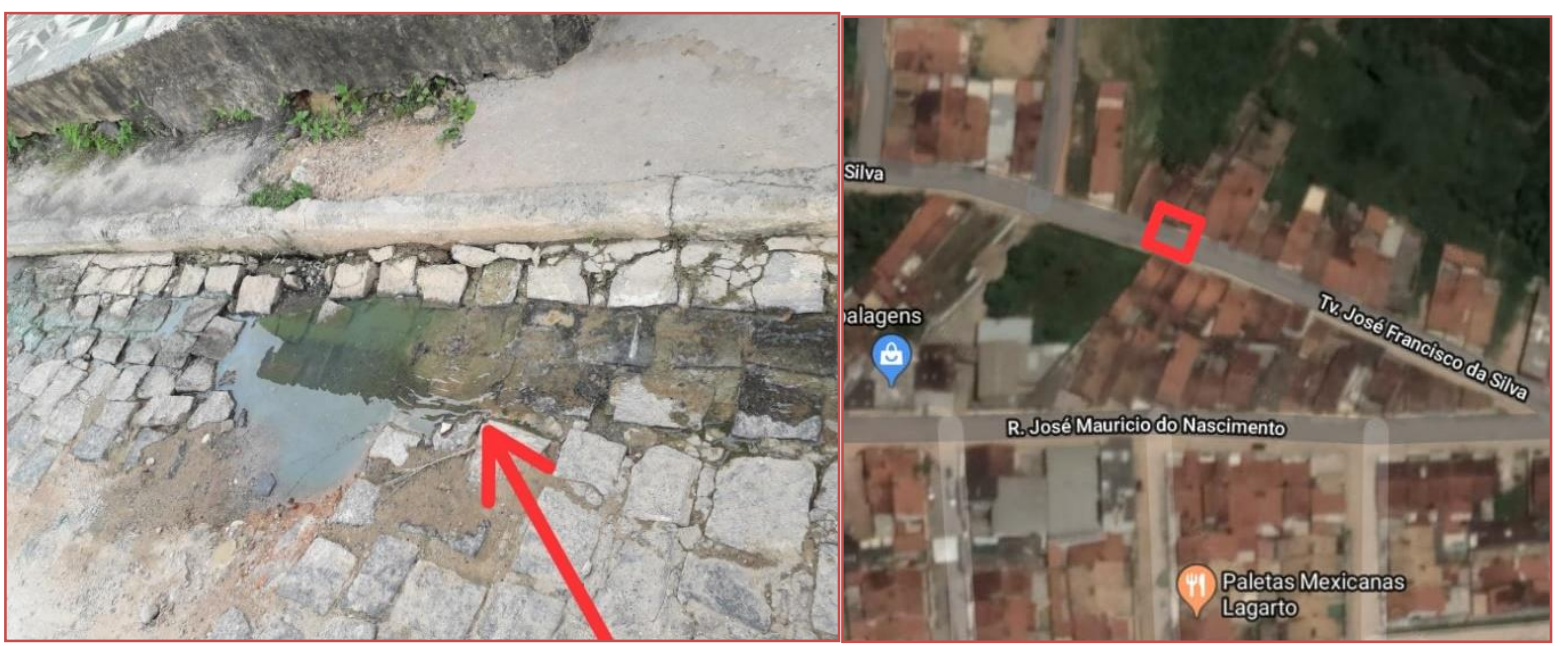

Fonte: Autoria própria (2019)

\subsection{CARACTERÍSTICAS DO ESGOTO SANITÁRIO DE LAGARTO}

A maioria das cidades inseridas na Bacia do Piauí não possuem coleta de esgoto sanitário. Dos 15 municípios, apenas 5 (cinco) possuem rede coletora, sendo 2 (dois) por responsabilidade da DESO, Lagarto e Simão Dias.

Através dos dados fornecidos por BRASIL (2019), o município de Lagarto possui 25,2 km de rede coletora, com 10,7 m/lig de extensão por ligação, coletando $313.240 \mathrm{~m}^{3} /$ ano de efluentes com um total de 2.096 de ligações totais e ativas, sendo coletada através do sistema separador absoluto.

Esse tipo de sistema é o mais utilizado no Brasil pelo fato de possuir um barateamento no custo dos materiais, eles são facilmente encontrados, facilidade na execução e menor intervalo de tempo na construção sendo possível ser executada por etapas, podendo iniciar da localidade de maior importância sem aumento de custo, evita o aumento de vazões em períodos de chuvas intensas, não é necessário pavimentação das vias públicas e menor extensão de tubulações de grandes diâmetros (ALEM SOBRINHO e TSUTIYA (2011) e AZEVEDO NETTO (1998)).

O município ainda tem uma população de 6.328 pessoas atendidas, o que representa apenas um índice de coleta de 11,48\%, sendo que o total coletado passa por tratamento secundário de lagoa facultativa e após o tratamento segue para o Riacho Angola Cachorro. Todo esse efluente também é faturado.

\subsubsection{ESTAÇÃO DE TRATAMENTO EXISTENTE E PRELIMINAR}

De acordo com o Atlas de Esgoto Brasil (2017), através do Sistema Nacional de Informações sobre Recursos Hídricos, foi gerado o Relatório de Esgoto Sanitário Municipal, o qual traz dados sobre tratamento de esgoto existente em 2013 e o planejamento estudado para 2035. 
Pelos dados de 2013, o município possui uma estação de tratamento ETE-LAGARTO (Figura 5) com uma vazão de $30 \mathrm{~L} / \mathrm{s}$ de efluente, carga de $279,1 \mathrm{~kg}$ DBO/dia e carga lançada de 108,0 kg DBO/dia. 0 corpo receptor após o tratamento é o Rio Piauí com uma vazão de 123,2 L/s. Uma população urbana de 51.684 habitantes, com uma população atendida de 5.168, tratada por lagoa facultativa e uma eficiência obtida de $61,3 \%$, menor que o disposto, que deve ser de $80 \%$, não sendo sistema integrado.

Figura 5: Esquema do esgoto da cidade de Lagarto em 2013.

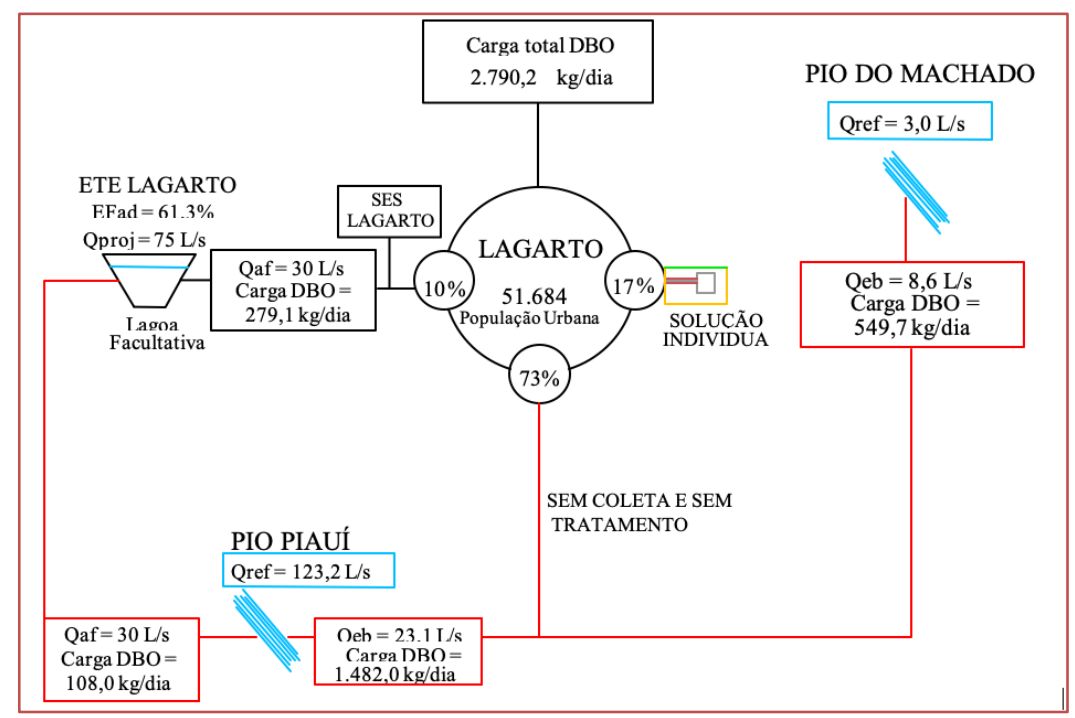

Fonte: BRASIL (2017).

Na Figura 6 é possível verificar o baixo índice de atendimento na coleta de esgoto, com apenas 10\% sendo coletado e com tratamento, $17 \%$ da população faz tratamento por soluções individuais, $73 \%$ não possui coleta e tampouco tratamento.

Figura 6: Gráfico: Índice de atendimento do esgoto de Lagarto em 2013.

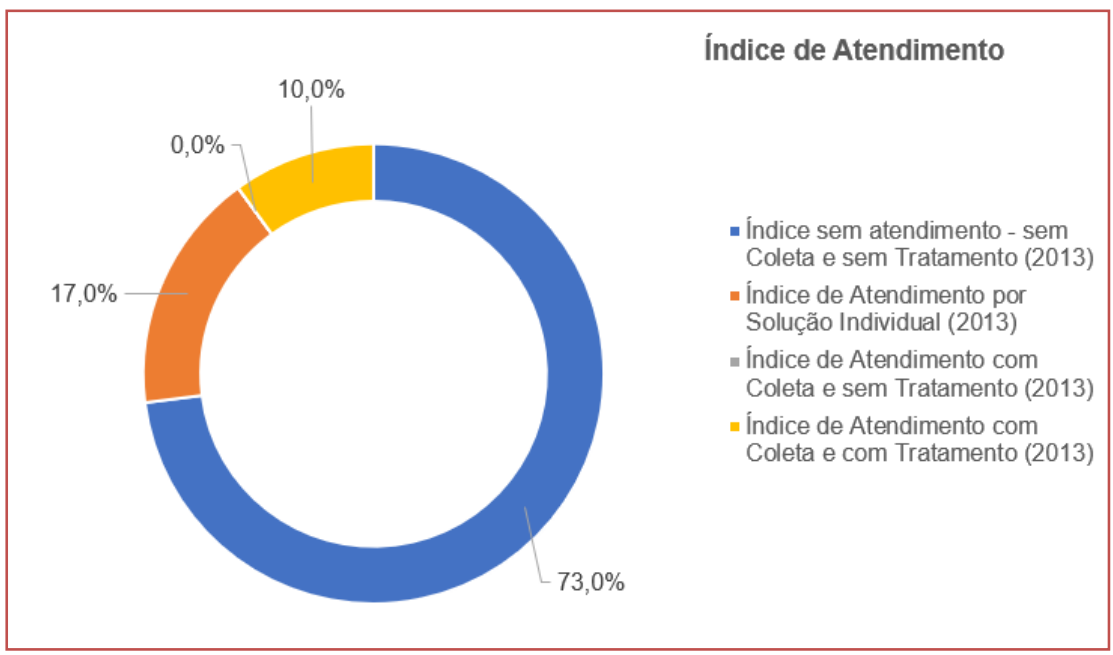

Fonte: BRASIL (2017).

Segundo dados da Brasil (2017), em uma análise preliminar de 2035, as características de efluente serão: vazão afluente de 410,6 L/s, carga de afluente de 3.819,9 kg DBO/dia e carga lançada de 1.478,3 kg DBO/dia. As estimativas do IBGE apontam 70.739 habitantes urbanos todos atendidos pelo sistema de esgoto sanitário e ainda através do tratamento secundário convencional de lagoas facultativas. Na Figura 7 é possível observar dados preliminares. 
Figura 7: Gráfico: Prognóstico do Índice de atendimento do esgoto para 2035.

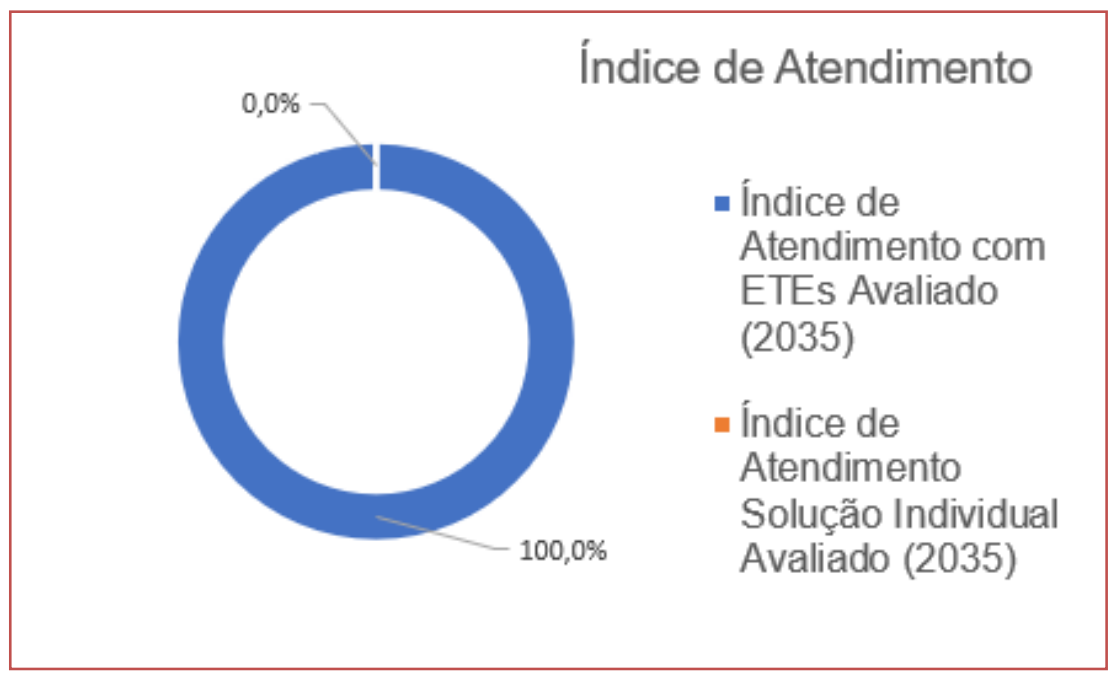

Fonte: BRASIL, (2017)

A Figura 7 aponta que em 2035, o índice de atendimento com a ETE analisada seria de 100\%, assim sendo, não haverá soluções individuais. 0 esquema abaixo (Figura 8) mostra a coleta de esgoto no qual, na zona urbana o esgoto é $100 \%$ coletado, tratado e despejado no Rio Piauí, já na zona rural 17,2\% continua com soluções individuais.

Segundo o G1(2017), se dos valores gastos com saneamento fosse descontada a inflação, ficariam congelados nos últimos anos. Nos últimos anos, o investimento com água e esgoto são altos, mesmo assim, se atingir as metas do Plano Nacional de Saneamento Básico fixadas em 2013 e universalizar em 20 anos os serviços de água e esgoto no Brasil, demandaria de um investimento de 300 bilhões de reais e mantendo o ritmo atual as metas de abastecer $100 \%$ da população com água tratada e mais de $90 \%$ de domicílios com rede coletora de esgoto só será atingida após 2054.

Figura 8: Esquema o esgoto da cidade de Lagarto em 2035.

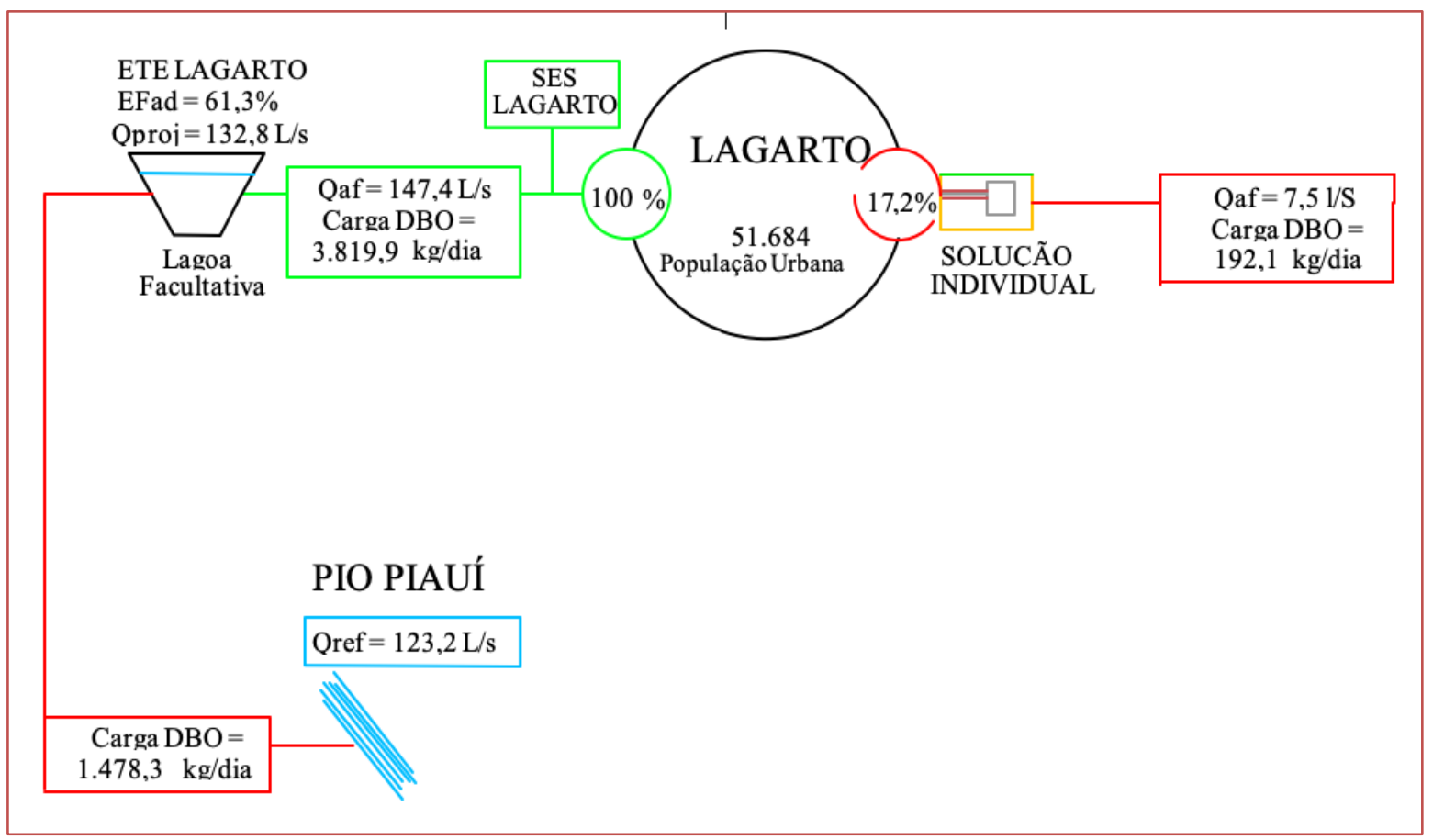


Com o início das obras do esgoto sanitário em 2015 e término previsto para final de 2017 e ainda não concluídas, as obras foram interrompidas pela prefeitura por causarem vários transtornos na infraestrutura da cidade. A empresa contratada da DESO começou o serviço mal feito, deixando valas abertas nas ruas e interrompendo em vários pontos de locomoção da população. A Figura 9 mostra a situação da cidade em períodos de fortes chuvas com a força das águas essas valas se abrem formando crateras.

Figura 9: Obras do esgoto sanitário em Lagarto.
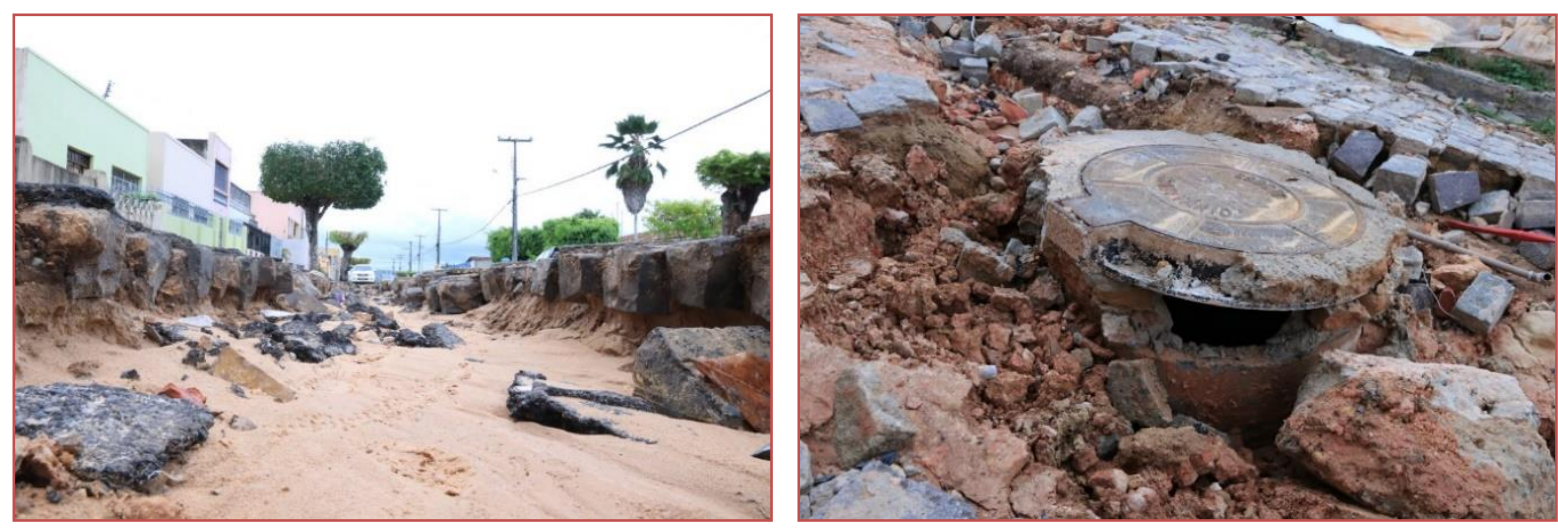

Fonte: Autoria própria (2019).

\subsection{ANÁLISE DOS QUESTIONÁRIOS}

A análise dos dados coletados junto à população com gráficos que revelam a real situação passada pelos moradores do centro da cidade e em 04 (quatro) bairros carentes do município de Lagarto. Foram distribuídos 30 (trinta) questionários contendo 10 questões, divididos em 05 (cinco) sobre abastecimento de água e 05 (cinco) sobre esgoto sanitário, ambos objetivos.

Através do questionário aplicado Tabela 4, verificou-se que há uma grande deficiência em relação a falta de água constatada pelos participantes.

Tabela 4: Questões da entrevista sobre abastecimento de água.

\begin{tabular}{c|l|c|c} 
NNo & \multicolumn{1}{|c}{ PERGUNTA } & SIM & NÃO \\
\hline 1 & Em sua casa falta água? & 12 & 18 \\
\hline 2 & A qualidade da água que chega em sua casa é boa? & 20 & 9 \\
\hline 3 & Você conhece o manancial que abastece sua casa? & 21 & 9 \\
\hline 4 & Próximo a sua casa existem vazamentos? & 20 & 10 \\
\hline 5 & Você sabe para onde vai a água depois do escoamento da sua casa? & \\
\hline
\end{tabular}

Fonte: Autoria própria (2019).

Foi averiguado como pode-se observar na Figura 10 que, 40\% das pessoas sofriam com a falta de água na rede de abastecimento, principalmente nos meses mais quentes do ano. Quanto a qualidade da água, 33\% dos entrevistados não aprovaram, afirmando não estar dentro dos padrões de potabilidade, já os $67 \%$ consumem da maneira que chegam em suas residências.

Ao falar sobre o manancial que abastece as residências, $70 \%$ dizem conhecer, outros 30\% não conhecem e preferem não conhecer. Ao referir-se sobre os vazamentos, $67 \%$ conhecia algum ponto ali próximo e alegava que seria o que ocasionava a falta de água. Cerca de $53 \%$ das pessoas sabiam para onde iam as 
águas depois das suas casas, outros $47 \%$ não sabiam onde iam parar a água. A Figura 11 retrata um pouco do que foi citado anteriormente.

Figura 10: Gráfico: Resultados do questionário sobre abastecimento de água.

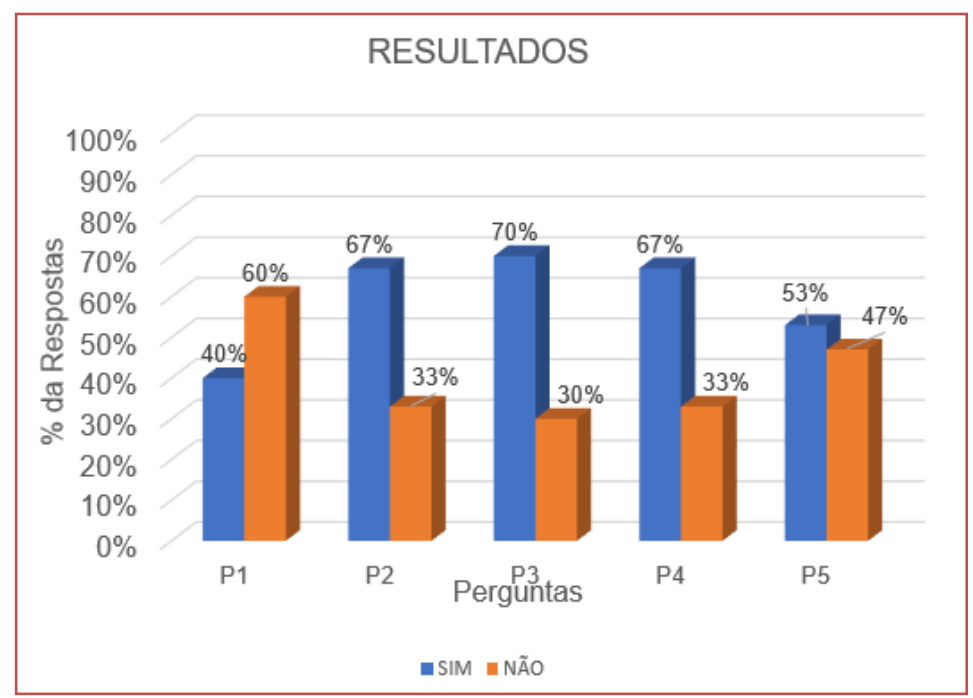

Fonte: Autoria própria, 2019

Figura 11: Pontos de vazamentos.
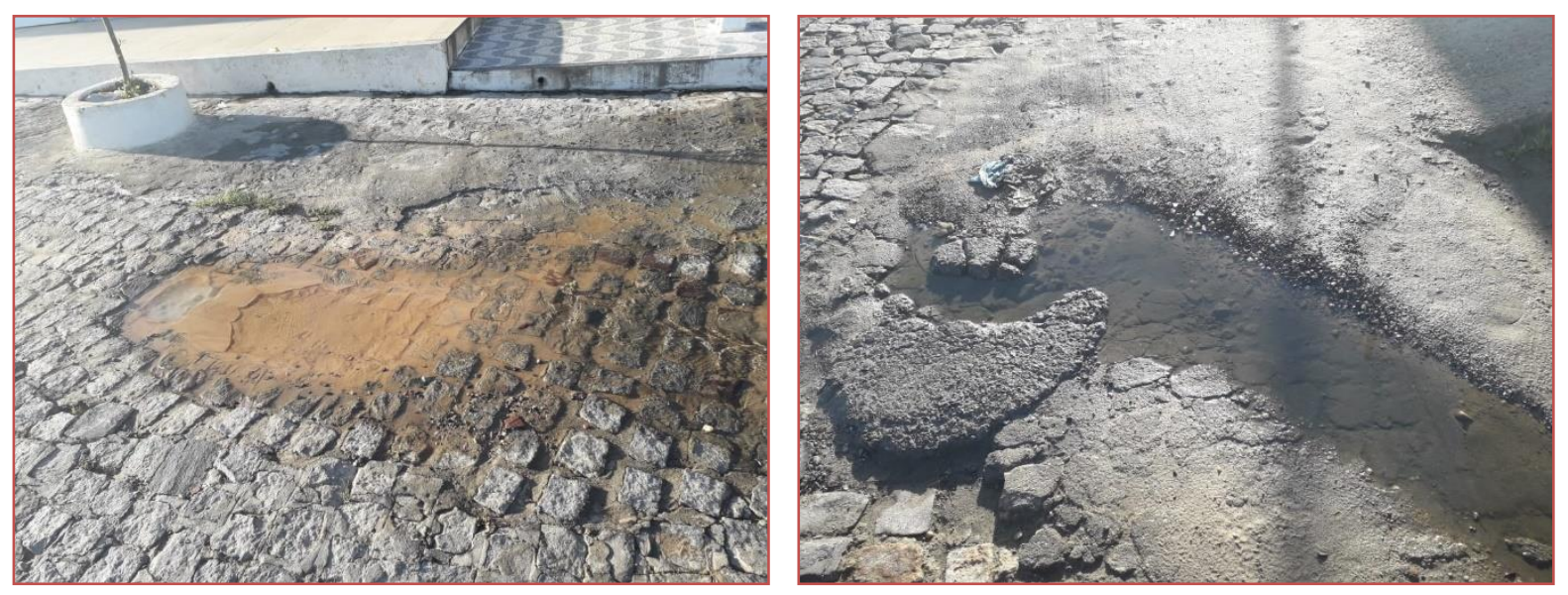

Fonte: Autoria própria (2019).

De acordo com os resultados apresentados no Tabela 5, maioria da população não possui rede coletora de esgoto e menos ainda um tratamento adequado. Desde 2014, quando as obras do esgoto iniciaram, que não foram concluídas, os problemas de saneamento básico só aumentaram. 
Tabela 5: Questões da entrevista sobre esgoto sanitário.

\begin{tabular}{c|l|c|c}
\hline № & \multicolumn{1}{|c}{ PERGUNTA } & 6 & 24 \\
\hline 6 & Sua casa está ligada a rede coletora de esgoto? & 16 & 14 \\
\hline 7 & $\begin{array}{l}\text { Você sabe para onde o esgoto é levado, se é tratado ou se é levado } \\
\text { diretamente ao rio? }\end{array}$ & 14 & 16 \\
\hline 8 & $\begin{array}{l}\text { Existem locais próximos a sua casa com esgoto lançado em locais } \\
\text { inadequados? }\end{array}$ & 6 & 24 \\
\hline 9 & O escoadouro do banheiro da sua residência é ligado à rede pública? & 0 & 30 \\
\hline 10 & Nos últimos 4 anos, a situação do esgoto em seu bairro melhorou? & 0 \\
\hline
\end{tabular}

Fonte: Autoria própria (2019).

Com base nas informações passadas pelos moradores, foi possível verificar a situação que se encontra as condições de saneamento básico.

Conforme o percentual apresentado na Figura 12 obtido através das respostas, é possível observar em campo, através de fotografias apresentadas a seguir que $80 \%$ dos entrevistados relataram não possuir rede coletora de esgoto, $47 \%$ não sabiam ou não tinham conhecimento do destino dos esgotos domiciliares produzidos, $47 \%$ das pessoas tinham conhecimento da poluição de mananciais causada pelos esgotos, apenas $20 \%$ possui o escoadouro do banheiro ligado à rede pública e $100 \%$ declararam não haver nenhuma melhora nos últimos 4 anos, apenas piorou com as obras inacabadas da rede coletora de coletora de esgoto a Figura 13 mostra um pouco sobre essa realidade.

Figura 12: Gráfico: Resultados do questionário sobre esgoto sanitário.

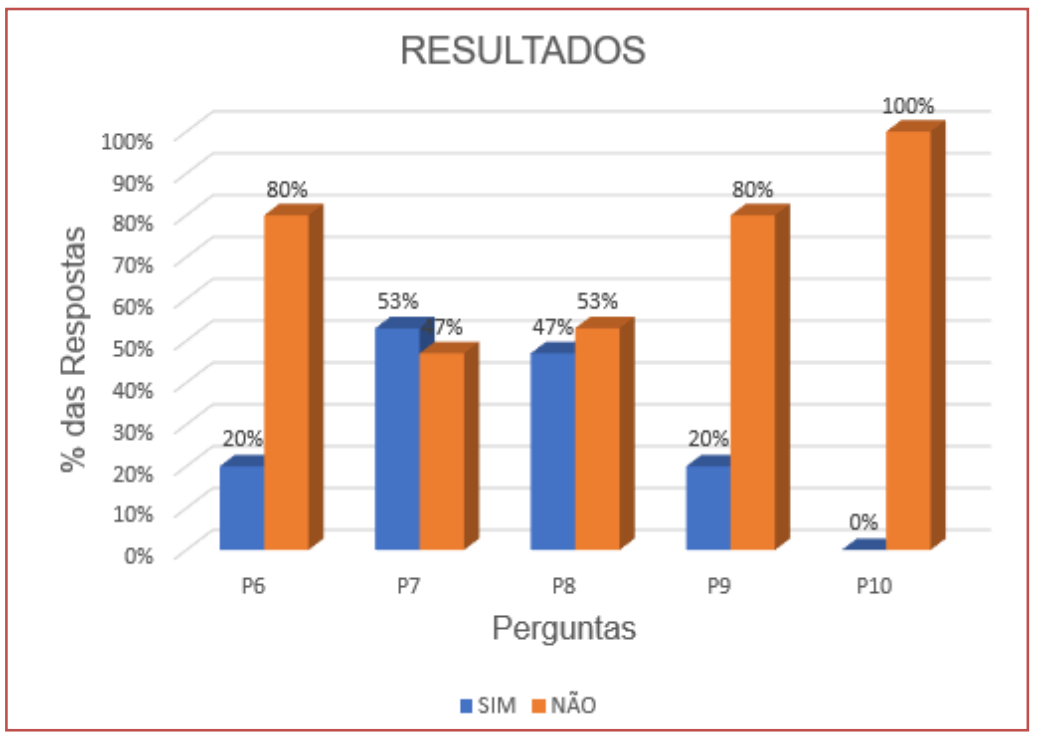

Fonte: Autoria própria (2019). 
Figura 13: Obras de esgoto inacabadas causando transtornos para a população.
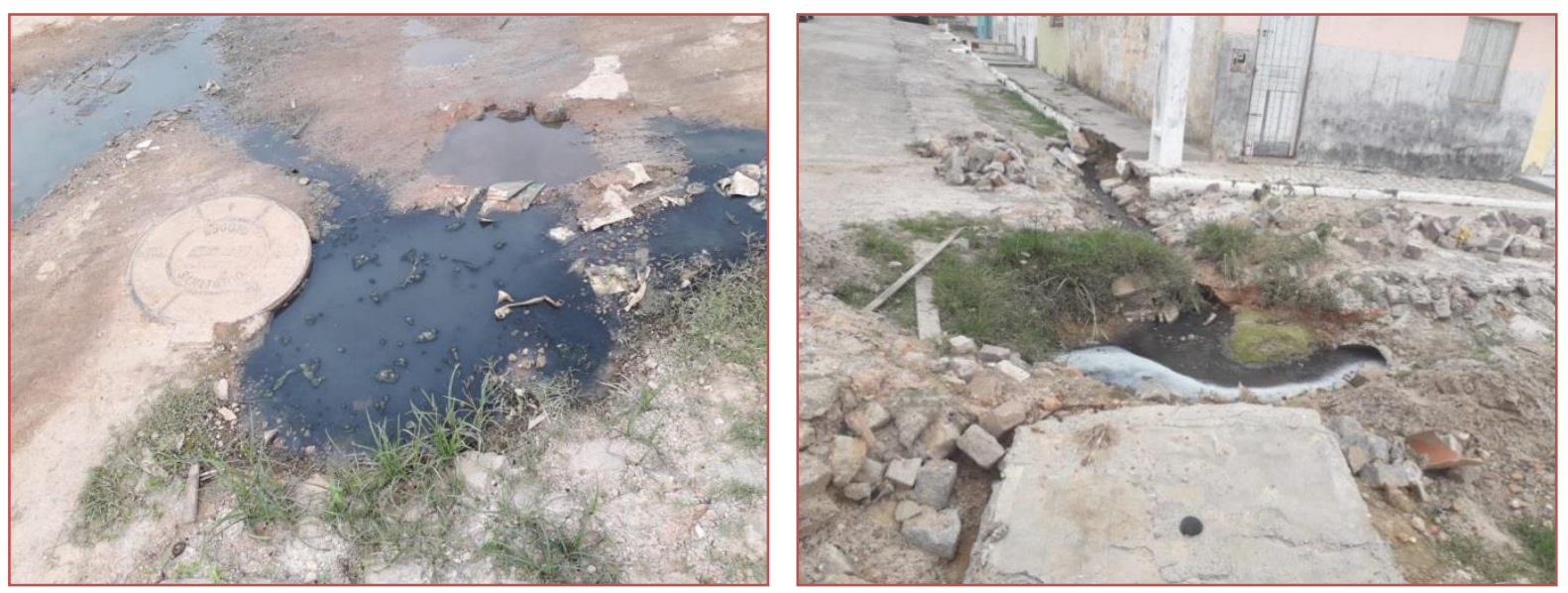

Fonte: Autoria própria (2019).

\section{CONSIDERAÇÕES FINAIS}

Portanto, o sistema de abastecimento de Lagarto apresenta algumas dificuldades quanto as exigências da Organização das Nações Unidas.

No que diz respeito a quantidade e qualidade da água, o município possui uma quantidade de água satisfatória sem a necessidade de investimento até 2025 (ANA, 2010). Já na qualidade, a DESO utiliza o tratamento de filtração direta de fluxo ascendente (filtro russo), esse tipo de filtro possui uma desvantagem por não tratar a água com turbidez elevada. Portanto é indicado para água bruta de cor e turbidez baixas e sem variação de qualidade.

Verificou-se que para a quantidade de água tratada e disponibilizada para a população há um déficit que é causado pelos altos índices de perdas de distribuição e consequentemente de faturamento constatado no município. 0 município apontou um índice de perda na distribuição de $53,79 \%$, superior à média nacional em 2016 que é de 38,01\%. Desta forma, a água que seria capaz de suprir a demanda é perdida antes de chegar aos consumidores e com isso, resulta em um consumo médio per capita abaixo do recomendado pela organização das Nações Unidas.

O sistema de esgoto sanitário foi constatado ser insuficiente e ineficiente, pois o tratamento possui apenas $61,3 \%$ de eficiência, onde apenas $10 \%$ dos habitantes são beneficiados com a coleta e tratamento do esgoto, o restante da população sofre com a falta de saneamento adequado, tanto na sede quanto nos bairros da cidade. Com a estimativa de 2013, o sistema de esgoto a ser implantado em 2035, 100\% da população urbana teria o esgoto coletado e tratado o que preservará tanto a saúde da população quanto o manancial que abastece a cidade.

A aplicação do questionário na sede da cidade e nos bairros comprovam que os dados retirados dos órgãos são reais. Muitas pessoas ainda sofrem com a falta de água, o município de Lagarto necessita da universalização do bem para que todos os habitantes tenham acesso de maneira satisfatória.

A partir do estudo realizado sugerem-se os seguintes temas para estudos futuros que venham a contribuir para um maior esclarecimento sobre o saneamento da cidade de Lagarto como a redução de perdas no sistema de abastecimento de água, melhoria no tratamento da qualidade da água na ETA - Lagarto, a eficiência no tratamento do esgoto sanitário e planejamento para as obras de coleta e tratamento do esgoto. 


\section{REFERÊNCIAS}

[1] ALEM SOBRINHO, P.; TSUTIYA, M. T. Coleta e Transporte de Esgoto Sanitário, 3 ed. Rio de Janeiro: ABES, 2011, $548 \mathrm{p}$.

[2] AZEVEDO NETTO, J. M.; FERNANDEZ, M. F.; ARAUJO, R.; ITO, A. E.; Manual de Hidráulica. 8ª Edição Ed. Edgar Blucher Ltda. São Paulo, 1998.

[3] BERNARDO, Luiz di (Org.). Tratamento de água para abastecimento por filtração direta. São Carlos: ABES-RJ, 2003. 498 p. (Projeto PROSAB).

[4] BRASIL. Agência Nacional de águas. Ministério de Meio Ambiente. Atlas Brasil: Abastecimento Urbano de Água: resultados por estado. Volume 2. Brasília: Ana, 2010. 90 p.

[5] BRASIL. Agência Nacional de águas. Secretaria Nacional de Saneamento Ambiental. Atlas de Esgoto: Despoluição de Bacias Hidrográficas. Brasília: Ana, 2017. 88 p.

[6] BRASIL. Ministério do Desenvolvimento Regional. Snis. Sistema Nacional de Informações sobre Saneamento: Série Histórica dos Serviços de Água e Esgoto. 2017. ed. Brasília: Snis, 2019. 226 p.

[7] G1: 10 anos após Lei do Saneamento, setor ainda atrai pouco investimento. Rio de Janeiro, 20 fev. 2017.

[8] GERHARDT, Tatiana Engel; SILVEIRA, Denise Tolfo (Org.). Metodos de Pesquisa. Porto Alegre: Editora da Ufrgs, 2009. $120 \mathrm{p}$.

[9] OLIVEIRA, Gesner et al. Perdas de água 2018 (snis 2016): desafios para disponibilidade hídrica e avanço da eficiência do saneamento básico. São Paulo: Go Associados, 2018. 67 p. (Instituto Trata Brasil).

[10] PAULI, Dante Ragazzi. Perdas de Água. Abes. São Paulo, p. 1-3. 17 mar. 2015.

[11] Bahia: ANÁLISE \& DADOS, Salvador, v. 13, p.341-345, 2003.

[12] RICHTER, C. A.; AZEVEDo NETTO, J. M. Tratamento de água: tecnologia atualizada. São Paulo: E. Blücher, 1991.

[13] SERGIPE. Secretaria de Estado do Meio Ambiente e Recursos Hídricos. (org.). Elaboração dos Planos das Bacias Hidrográficas dos Rios Japaratura, Piauí e Sergipe: Diagnóstico da Bacia Hidrográfica do Rio Piauí. Aracaju: Semarh, 2014. 275 p.

[14] SERGIPE. Deso. Companhia de Saneamento de Sergipe. Relatório Anual de Informação ao Consumidor. Lagarto: Deso, 2018. 2 p. 


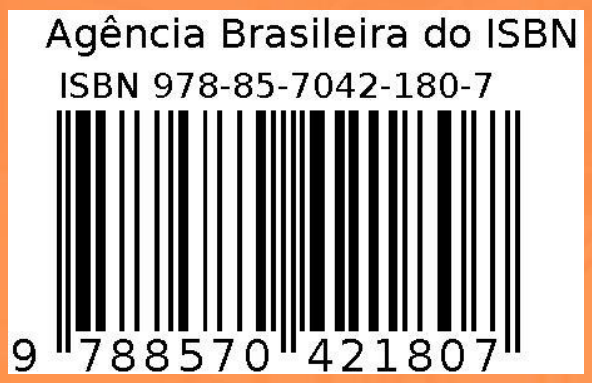

